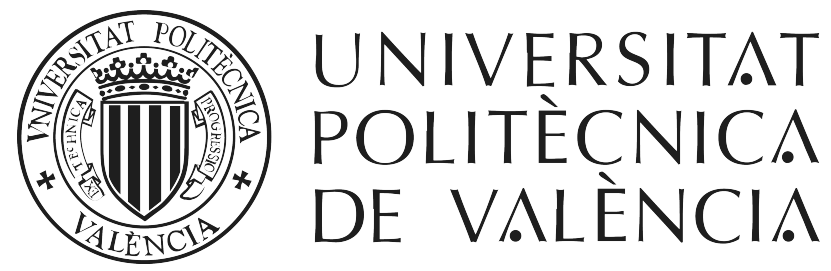

Biotechnology Doctoral Program

\title{
Therapeutic approaches and development of genomic diagnostic tools for Usher syndrome
}

\section{Carla Fuster García}

Doctoral Thesis

November 2019

Supervisors:

José María Millán Salvador

Elena Aller Mañas 


\section{C) 2019 Carla Fuster García}

PhD dissertation, 2019

Instituto de Investigación Sanitaria La Fe

Biotechnology Doctoral Program, Universidad Politénica de Valencia

Valencia, Spain

All material contained in this work is original unless otherwise stated, including cover, text, and figures. 
El Dr. José Ma Millán Salvador, Facultativo Especialista e Investigador Principal del grupo de Biomedicina Molecular, Celular y Genómica perteneciente al Instituto de Investigación Sanitaria La Fe (IIS La Fe).

La Dra. Elena Aller Mañas, Técnico Titulado Superior de la Unidad de Genética y Diagnóstico Prenatal del Hospital Universitario y Politécnico La Fe, y miembro del grupo de Biomedicina Molecular, Celular y Genómica perteneciente al IIS La Fe.

\section{HACEN CONSTAR QUE:}

El trabajo de tesis doctoral titulado "Therapeutic approaches and development of genomic diagnostic tools for Usher" que presenta Carla Fuster García, Licenciada en Ciencias Biológicas, para optar al título de Doctora por la Universitat Politècnica de València, ha sido realizado en el grupo de Biomedicina Molecular, Celular y Genómica del IIS La Fe bajo su dirección y que reúne las condiciones para ser defendida por su autora.

Para que conste, en cumplimiento de la legislación vigente, firman el presente certificado en Valencia, a 21 de Octubre de 2019.

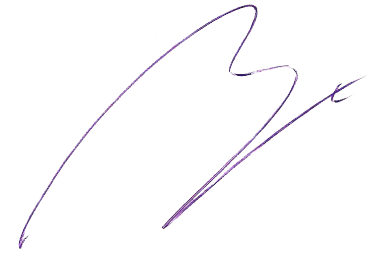

Fdo. Dr. José Ma Millán Salvador

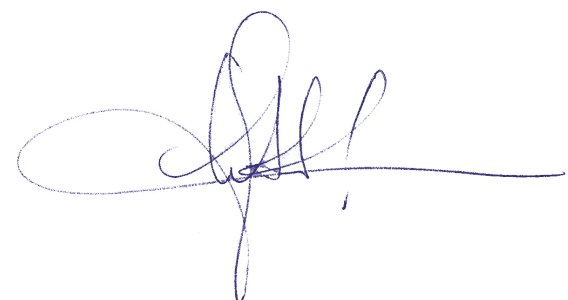

Fdo. Dra. Elena Aller Mañas 

A mis padres

"The true delight is in the finding out rather than in the knowing." - Isaac Asimov 



\section{ACKNOWLEDGEMENTS (AGRADECIMIENTOS)}

Han sido numerosas las personas que, de una forma u otra, han jugado algún papel durante mi tesis y quiero dedicar unas líneas a algunas de ellas.

Mis primeros agradecimientos están destinados a mis dos directores de tesis:

A Chema, no sólo por acogerme en tu grupo, sino por considerar siempre mis ideas o proyectos seriamente y por confiar en mi criterio a pesar de mi inexperiencia. Gracias, también, por anteponer tantas veces nuestro desarrollo profesional y actuar en nuestro beneficio. A Elena, por aportarme esa sensatez que a veces me falla y darle rumbo a cada etapa del trabajo que hemos llevado a cabo. Gracias por ser una mentora de trato tan cercano, por preocuparte por mí en todos los aspectos, y por dedicar esfuerzo y tiempo personal para compaginar tu propio trabajo con la supervisión de esta tesis.

También quiero dar las gracias a los demás integrantes del equipo BMCG:

A Teresa, por ayudarme tantas veces y quitarme la tontería tantas otras; y a Gema, por ser un pilón recurrente para resolver mis dudas. Sabed ambas que también os considero directoras de mi tesis. A Rafa, por tu buen humor, por verle siempre solución a todo problema, y por ser nuestro comodín informativo y fuente de muchas ideas. A Regina, por ser un referente y por el apoyo moral que brindas cada vez que aparecemos en tu despacho convertido en consulta. Mucha suerte en tu próxima etapa, realmente te lo mereces. A Cristina, que, aun habiendo volado ya, sigues siendo parte de la familia. Gracias por haberme valorado tanto, no olvidaré las oportunidades que me has dado. A Loli, por enseñarme, por romper los moldes de lo que tú llamas "tecnicucho", y por todos esos buenos ratos dentro y fuera del laboratorio. Doy también las gracias al resto de mis compañeros de grupo, y a los muchos estudiantes que han pasado por el laboratorio y nos han echado una mano en los proyectos.

Pero, más aún y con especial cariño, a los otros dos componentes de mi tridente. A Anapi, mi drama queen y nuestro enlace covalente, porque a pesar de todas nuestras discusiones que tanto escandalizan, no habría podido tener mejor vecina de bancada. A MiLoRe, por escucharme y comprenderme siempre, por ser esa parte buena de nuestro núcleo... ¡Y por amortiguar nuestros rifirrafes! Gracias a ambas por ser mis hermanas en esta aventura, por compartir las desazones y alegrías de este mundillo, por quererme aun siendo una seta. Sin vosotras, no habría sido lo mismo. 
Gracias también a todo mi grupillo de Philly que tan rápida y cálidamente me recibieron en su cuadrilla. En especial a Berta y Álvaro, por allanarme tanto el camino; y a Alba y Vicky, que desde el primer minuto os desvivisteis por que aprovechara al máximo mi estancia.

Many thanks to Dr. Hakonarson and all the CAG members for allowing me the opportunity to learn from such a proficient and nice team during those six months.

No me olvido tampoco del resto de amigos que, sólo con interesarse por mi trabajo o darme apoyo moral, también me ayudado durante estos años.

Y, por supuesto, gracias a mi familia.

A mis abuelos, porque sé que muchas de mis capacidades las he heredado de ellos, y porque sé la enorme ilusión que les habría hecho ser partícipes de este momento. En especial, a mi abuelo Jesús, quien sembró mi interés por la investigación y a quien le hubiese entusiasmado saber que finalmente desarrollé su profesión platónica.

A Adrián, mil gracias (y me quedo corta). Es una gran suerte poder compartir las ilusiones e inquietudes del gremio con mi compañero de vida y de vocación. Gracias por sacarme de tantos apuros, porque literalmente sin ti me habría estancado. Gracias por escucharme cuando he necesitado desahogarme, por animarme y aconsejarme, y por disfrutar con mis éxitos. Gracias, en suma, por ser mi cómplice en todo.

Gracias, de manera muy profunda, a mis padres, a quienes dedico esta tesis. Por innumerables motivos que, a fin de cuentas y de forma desvirtuada, se reducen a una esencia: por apoyarme siempre en todo, por las oportunidades que me habéis dado, por educarme como lo habéis hecho, y por vuestro desmedido cariño. Porque si he llegado hasta aquí, ha sido por vosotros, y porque si soy quien soy, es por vosotros. Gracias papá, gracias mamá, por ser como sois.

Finalmente, mi más sincera gratitud a todos los pacientes y sus familiares que han participado en los estudios. Al fin y al cabo, todo esto es por vosotros. Gracias por vuestra confianza. Quiero creer que nuestro empeño, si no el de otros, acabará traduciéndose en una solución. 




\section{THESIS OUTLINE}

\section{Abstract}

Usher syndrome (USH) is an autosomal recessive disorder defined by sensorineural hearing loss $(\mathrm{SNHL})$, and a retinal dystrophy known as retinitis pigmentosa (RP) that produces progressive visual failure. In addition, some cases also present with vestibular dysfunction, which implies a deficit in balance. Despite USH being the most common form of deafblindness of genetic origin, its low prevalence among the population confers the disease the rare trait. Excluding the hearing aids or cochlear implants assisting in the audiological impairment, there is to date no cure for the disease.

There are three types of USH (USH1, USH2 and USH3) according to the severity and onset of the symptoms. The condition also shows a genetic heterogeneity, since there are at least 10 genes known to be causative of the syndrome, each usually responsible for one of the three types of the syndrome. However, mutations in USH2A are the most frequent cause of the disease, and this is due in a large measure to the recurrence of the c.2299delG pathogenic variant. Therefore, a therapeutic approach targeting this particular mutation would befit a considerable number of patients.

To this end, a gene editing assay to reverse this specific genetic anomaly was developed in this thesis by means of the groundbreaking CRISPR/Cas9 system. Simply put, the technology relies on a DNA-cleaving enzyme steered by an RNA fragment towards a precise genomic region, on the basis of complementary base-pairing. The lesion is then endogenously repaired, usually through an error-prone mechanism that tends to yield indels around the cleavage site. However, homologous recombination can also be induced as a repair pathway after the double-stranded break if a sequence template is opportunely accessible. This process can be leveraged to intentionally introduce a few nucleotide changes, like the reversion of certain pathogenic variants, by exogenously providing an almost identical and carefully preset fragment to be used for the recombination.

Several locus-specific CRISPR complexes were designed and the distinct constructs first were tested in HEK293 cells as pilot scheme and single-guide RNA (sgRNA) triage. The sgRNA-1 was deemed the most suitable targeting the guanine deletion at the 2299 coding position, and it was used to proceed with the mutation correction on patient-derived cells. Fibroblasts harboring the homozygous pathogenic allele were isolated from a skin biopsy 
and subjected to the devised CRISPR process. The trial resulted in a mutation correction rate of $2.5 \%$, ascertained by RFLP assay and targeted deep-sequencing of the treated cells.

This successful proof of concept demonstrates the feasibility of the technology to restore the integrity of the USH genes. This stands as a potential therapy once the system is refined, although, true to the features of precision medicine, it is genotype-dependent. Therefore, the molecular diagnosis of USH patients is not only relevant to better understand the disease mechanisms and the functional bases of the engaged organs, but also in anticipation of such upcoming customized treatments that will be conditioned to the mutational profile.

Accordingly, another goal of this thesis was the genetic characterization of a collection of molecularly undiagnosed USH patients. Given the genetic diversity of the disease, the procedure required the implementation of high-throughput sequencing, a technology that enables in bulk sequencing of any number of selected loci (or the indiscriminate totality) of the genome. The first phase implied the targeted sequencing of the coding-relevant regions of all known causative or disease-associated genes at the moment (MYOTA, USH1C, CDH23, PCDH15, USH1G, CIB2, USH2A, ADGRV1, WHRN, CLRN1, HARS, PDZD7, CEP250 and C2orf71), by means of an amplification-capture method and a proton-sensing platform. The study, comprising a cohort of 58 previously unscreened patients, enabled the identification of 42 novel putative pathogenic mutations, and an etiologic-allele detection ratio shy of $83 \%$. Remarkably, one of the subjects owed its deafblindness to nonsense mutations in CEP250, which is one of the latest USH-associated genes. However, an exhaustive review of the clinical features unmasked the retinal degeneration as a cone-rod dystrophy rather than $\mathrm{RP}$, in consonance with other reports, which reinforced the linkage of the gene to an USHlike phenotype.

The remaining portion of unresolved cases, from this and other analogous works, lead to suspicion of the existence of other genes accountable for USH. Hence, the complete exome of such panel-negative cases was screened through whole exome sequencing. This venture provided relevant findings in six of the surveyed samples. One subject was plainly exposed as an USH phenocopy by harboring pathogenic splice-site mutations in two independent genes, TECTA and REEPG, the former responsible for the SNHL and the latter for the RP. Similarly, RP-causative variants in EYS were detected in another patient, yet no pathogenic changes explaining the HL were discovered. 
Three additional individuals were ultimately unveiled as USH misdiagnosed cases, being the $\mathrm{HL}$ actually absent or ambiguous. One of the patients in this set was homozygous for a mutation in CNGB1, already known to be accountable for RP. The other two cases showed a more peculiar outcome being compound heterozygous for putatively pathogenic variants in genes generally associated to other disorders. One presented a homozygous mutation in $G R N$, a gene associated to frontotemporal dementia under heterozygous condition and less commonly to combined RP for homozygous alterations. Indeed, this patient manifested a cognitive decline matching the less usual associated phenotype, which had been initially disregarded given the high population frequency of said ailment. The third subject was found to be a carrier of mutations in WDR19, a gene best associated with retinal disorders accompanied by renal signs and rarely with the isolated visual symptom.

The last case presented a homozygous nonsense variant in the AS/C5 gene, whose role has yet to be learned. However, since some correlations to visual and hearing functions have been reported for members of the same protein family, the public disposal of this evidence is convenient.

Altogether, the results obtained from this work attest to the importance of applying the most up-to-date technologies in the search of solutions for rare diseases that realistically pose a despairing therapeutic prognosis. In addition, the positive consequences of the genetic characterization of the patients are the corroboration (or else correction) of the initial diagnosis, and the contribution to the appraisal of demographic and genotypephenotype correlations, which ultimately aid in the understanding USH and other related diseases. 


\section{Resumen}

El síndrome de Usher (USH) es un trastorno autosómico recesivo definido por sordera neurosensorial (SNHL), y una distrofia retiniana conocida como retinosis pigmentaria (RP) que produce una pérdida visual progresiva. Algunos casos también presentan disfunción vestibular, que se traduce en problemas de equilibrio. A pesar de que USH es la forma más común de sordoceguera de origen genético, la baja prevalencia de la enfermedad en la población le confiere el carácter de rara. No existe cura hasta la fecha, a excepción de los audífonos o implantes cocleares que mitigan la discapacidad auditiva.

Según la gravedad y la aparición de los síntomas, se diferencian tres tipos de USH (USH1, USH2 y USH 3). La patología también muestra heterogeneidad genética, puesto que se conocen al menos 10 genes responsables, cada uno típicamente asociado a uno de los tres tipos sindrómicos. No obstante, las mutaciones en USH2A son la causa más frecuente de la enfermedad, debido a su vez en gran medida a la recurrencia de la variante patogénica c.2299delG. Por lo tanto, una aproximación terapéutica enfocada a esta mutación concreta beneficiaría a una parte considerable de los pacientes.

Con este propósito, en esta tesis se ha desarrollado un ensayo de edición génica para revertir dicha anomalía genética por medio del revolucionario sistema CRISPR/Cas9. Sucintamente, la tecnología está basada en una enzima de escisión de ADN, la cual es conducida a una región genómica precisa por medio de un fragmento de ARN acoplado gracias al fenómeno de emparejamiento de bases complementarias. La lesión se repara posteriormente de forma endógena, normalmente por medio de un mecanismo propenso a errores que tiende a producir pequeñas inserciones o deleciones alrededor del sitio de corte. Sin embargo, tras esta ruptura bicatenaria también puede inducirse el mecanismo de recombinación homóloga como alternativa de reparación si una secuencia molde se encuentra oportunamente accesible. Este proceso se puede aprovechar para introducir de forma dirigida algunos cambios en la secuencia nucleotídica, como la reversión de ciertas variantes patológicas, al proporcionar exógenamente un fragmento casi idéntico y cuidadosamente diseñado para la recombinación.

Se diseñaron varios complejos CRISPR específicos de locus que fueron probados primero en células HEK293 a modo de estudio piloto y con el fin de seleccionar el ARN guía (sgRNA) definitivo. El sgRNA-1 fue el más apropiado para la región diana, y se usó para proceder con la corrección de la mutación en células derivadas de pacientes. Se aislaron fibroblastos homocigotos para el alelo patogénico con la deleción de la guanina mediante 
una biopsia de piel, los cuales se sometieron al proceso de edición por CRISPR previamente trazado. La tasa de corrección de la mutación obtenida fue del $2.5 \%$, cuantificada tanto por estudio de RFLP como por secuenciación masiva a gran profundidad de la región de las células tratadas.

El éxito de esta prueba de concepto demuestra la viabilidad de la tecnología para su uso en la corrección de mutaciones patológicas de los genes USH. Ello representa una terapia potencial una vez se refine el sistema, si bien, según los principios de la medicina de precisión, es dependiente del genotipo. Por este motivo, el diagnóstico molecular de los pacientes con USH no sólo es relevante para comprender o ampliar los conocimientos sobre los mecanismos y bases funcionales de la enfermedad, sino también como paso previo a los tratamientos personalizados venideros que estarán condicionados al perfil mutacional de los pacientes.

En consecuencia, otro objetivo de esta tesis ha sido la caracterización genética de una colección de pacientes USH aún sin diagnóstico molecular. Dada la variabilidad genética de la enfermedad, dicho propósito requirió el uso de técnicas de secuenciación masiva que permiten la secuenciación simultánea de una selección de loci del genoma (o su totalidad indiscriminada). Una primera fase implicó la secuenciación dirigida de las regiones codificantes de todos los genes responsables o asociados a la enfermedad conocidos hasta ese momento (MYO7A, USH1C, CDH23, PCDH15, USH1G, CIB2, USH2A, ADGRV1, WHRN, CLRN1, HARS, PDZD7, CEP250 y C2Orf71), usando un método de captura por amplificación y una plataforma basada en la detección de protones. Este estudio, cuya cohorte incluyó 58 pacientes no escrutados previamente, permitió la identificación de 42 nuevas mutaciones presuntamente patológicas, y una tasa general de detección de alelos responsables de la enfermedad de prácticamente el 83\%.

Sorprendentemente, se observó que uno de los sujetos debía su sordoceguera a mutaciones en CEP250, uno de los últimos genes correlacionados con la enfermedad. Sin embargo, una exhaustiva revisión clínica reveló que la degeneración retiniana se trataba en realidad de una distrofia de conos y bastones en lugar de RP clásica. Estos hallazgos, en consonancia con resultados de otros trabajos, han permitido la consolidación del gen CEP250 como responsable de un fenotipo similar al USH (Usher-like).

El resto de casos sin resolver, tanto en este como otros trabajos análogos, induce a sospechar de la existencia de otros genes vinculados con USH. Así pues, se analizó el exoma íntegro de dichos casos negativos del panel por medio de secuenciación de exoma 
completo, lo cual proporcionó resultados relevantes en seis de las muestras estudiadas. Uno de tales sujetos resultó ser un claro caso de fenocopia de USH, al albergar mutaciones patogénicas de procesamiento de intrones en dos genes independientes, TECTA y REEP6, siendo el primero responsable de la SNHL y el segundo de la RP. De forma parecida, en otro paciente se detectaron variantes patológicas para RP en el gen EYS, pero no se identificó paralelamente ningún cambio genético que explicara la SNHL.

Tres individuos adicionales resultaron haber sido erróneamente diagnosticados como USH, dada la conclusiva inexistencia o ambigüedad de la sordera. Uno de ellos fue definido como homocigoto de una mutación en $C N G B 1$, ya reconocido como responsable de RP. Los otros dos pacientes del grupo fueron desvelados como casos más peculiares al presentar variantes supuestamente patológicas en genes asociados por lo general a otros trastornos. Concretamente, en uno de dichos sujetos se identificó una mutación en homocigosis en el gen GRN, cuyos defectos en estado heterocigoto están asociados a demencia frontotemporal y más raramente combinada con RP si ambos alelos se encuentran alterados. Ciertamente, en este paciente se había referido un deterioro cognitivo, inicialmente ignorado dada la alta frecuencia de este rasgo en la población general, concordante con este inusitado cuadro clínico. Por otro lado, el tercer paciente fue resuelto como heterocigoto compuesto de variantes en WDR19, un gen asociado en mayor medida a una distrofia retiniana acompañada de trastornos renales y, más raramente, a la forma aislada del síntoma.

En el último de los seis casos resaltados de este objetivo se detectó una mutación homocigota sin sentido en el gen $A S / C 5$, cuyo papel en el organismo todavía se desconoce. Sin embargo, se han correlacionado funciones visuales y auditivas para miembros de la misma familia proteica, por lo que la difusión pública de este resultado es oportuna por si se dieran otros casos similares.

En conjunto, los hallazgos obtenidos en este trabajo avalan la importancia del uso de las más novedosas tecnologías en la búsqueda de soluciones para enfermedades raras, las cuales, siendo realistas, presentan por ahora un pronóstico terapéutico bastante desamparado. Asimismo, otras consecuencias positivas en cuanto a la caracterización genética de los pacientes son la corroboración (o rectificación) del diagnóstico inicial, así como la contribución a la estimación demográfica y correlaciones de genotipo-fenotipo, que en definitiva ayudan en la compresión de USH y otras enfermedades relacionadas. 


\section{Resum}

La síndrome d'Usher (USH) és un trastorn autosòmic recessiu definit per sordera neurosensorial $(\mathrm{SNHL})$, i una distròfia retiniana coneguda com a retinosi pigmentària (RP) que produïx una pèrdua visual progressiva. Alguns casos també presenten disfunció vestibular, que es traduïx en problemes d'equilibri.

Encara que USH és la forma més comuna de sordoceguera d'origen genètic, la baixa prevalença de la malaltia en la població li conferix el caràcter de rara. No hi ha cura fins a la data, a excepció dels audiòfons o implants coclears que mitiguen la discapacitat auditiva. Segons la gravetat i l'aparició dels símptomes, es diferencien tres tipus d'USH (USH1, USH2 i USH3). La patologia també mostra heterogeneïtat genètica, ja que es coneixen almenys 10 gens responsables, cadascun típicament associat a un dels tres tipus sindròmics. No obstant això, les mutacions en USH2A són la causa més freqüent de la malaltia, a causa de la recurrència de la variant patogènica c.2299delG. Per tant, una aproximació terapèutica enfocada a aquesta mutació concreta beneficiaria a una part considerable dels pacients

Amb aquest propòsit, en aquesta tesi s'ha desenvolupat un assaig d'edició gènica per a revertir la dita anomalia genètica per mitjà del revolucionari sistema CRISPR/Cas9. Breument, la tecnologia està basada en un enzim d'escissió d'ADN, el qual és conduit a una regió genòmica precisa per mitjà d'un fragment acoblat d'ARN gràcies al fenomen d'emparellament de bases complementàries. La lesió es repara posteriorment de forma endògena, normalment per via d'un mecanisme propens a errors que tendix a produir insercions o delecions xicotetes al voltant del lloc de tall. No obstant això, després d'aquesta ruptura bicatenària també pot induir-se el mecanisme de recombinació homòloga com a alternativa de reparació si una seqüència motle es troba oportunament accessible. Aquest procés es pot aprofitar per a introduir de forma dirigida alguns canvis en la seqüència nucleotídica, com la reversió de certes variants patològiques, al proporcionar exògenament un fragment quasi idèntic i acuradament dissenyat per a la recombinació.

Es van dissenyar diversos complexos CRISPR específics de locus que van ser provats primer en cèlllules HEK293 a manera d'estudi pilot i a fi de seleccionar l'ARN guia (sgRNA) definitiu. L'sgRNA-1 va ser estimat el més apropiat per a la regió diana, i es va usar per a procedir amb la correcció de la mutació en cèllules derivades de pacients. Es van aïllar fibroblasts homozigots per a l'al·lel patogènic amb la deleció de la guanina mitjançant una biòpsia de pell, els quals es van sotmetre al procés d'edició per CRISPR prèviament traçat. La taxa de correcció de la mutació obtinguda va ser del 2.5\%, quantificada tant per estudi 
de fragments de restricció de longitud polimòrfica com per seqüenciació a gran profunditat de la regió de les cèl-lules tractades.

L'èxit d'esta prova de concepte demostra la viabilitat de la tecnologia per al seu ús en la correcció de mutacions patològiques dels gens USH. Això representa una teràpia potencial una vegada es refine el sistema, si bé, segons els principis de la medicina de precisió, és dependent del genotip. Per este motiu, el diagnòstic molecular dels pacients amb USH no sols és rellevant per a comprendre o ampliar els coneixements sobre els mecanismes i bases funcionals de la malaltia, sinó també com a pas previ als tractaments personalitzats futurs que estaran condicionats al perfil mutacional dels pacients.

En conseqüència, un altre objectiu d'aquesta tesi ha sigut la caracterització genètica d'una col-lecció de pacients USH encara sense diagnòstic molecular. Tenint en compte la variabilitat genètica de la malaltia, aquest propòsit va requerir l'ús de tècniques de seqüenciació massiva que permeten la seqüenciació simultània d'una selecció de loci del genoma (o la seua totalitat indiscriminada). Una primera fase va implicar la seqüenciació dirigida de les regions codificants de tots els gens responsables o associats a la malaltia coneguts fins a eixe moment (MYO7A, USH1C, CDH23, PCDH15, USH1G, CIB2, USH2A, ADGRV1, WHRN, CLRN1, HARS, PDZD7, CEP250 i C2orf71), usant un mètode de captura per amplificació i una plataforma basada en la detecció de protons. Aquest estudi, la cohort de la qual va incloure 58 pacients no escrutats prèviament, va permetre la identificació de 42 noves mutacions presumptament patològiques, i una taxa general de detecció d'al.lels responsables de la malaltia de pràcticament el $83 \%$.

Sorprenentment, es va observar que un dels subjectes devia la seua sordoceguera a mutacions en CEP250, un dels últims gens correlacionats amb la malaltia. No obstant això, una exhaustiva revisió clínica va revelar que la degeneració retiniana es tractava en realitat d'una distròfia de cons i bastons en lloc de RP clàssica. Aquestes troballes, d'acord amb resultats d'altres treballs, han permés la consolidació del gen CEP250 com a responsable d'un fenotip similar al USH (Usher-like).

La resta de casos sense resoldre, tant en aquest com altres treballs anàlegs, induïx a sospitar de l'existència d'altres gens vinculats amb USH. Així, doncs, es va analitzar l'exoma íntegre dels casos negatius del panell a través de seqüenciació d'exoma complet, cosa que va proporcionar resultats rellevants en sis de les mostres estudiades. Un de tals subjectes va resultar ser un clar cas de fenocopia d'USH, a l'albergar mutacions patogèniques de processament d'introns en dos gens independents, TECTA i REEPG, sent el primer 
responsable de la SNHL i el segon de la RP. De forma semblant, en un altre pacient es van detectar variants patològiques per a RP al gen EYS, però no es va identificar paral-lelament cap canvi genètic que explicara la SNHL.

Tres individus addicionals van resultar haver sigut erròniament diagnosticats com USH, donada la final inexistència o ambigüitat de la sordera. Un d'ells va ser definit com a homozigot d'una mutació en $C N G B 1$, ja reconegut com a responsable de RP. Els altres dos pacients del grup van ser desvelats com a casos més peculiars al presentar variants suposadament patològiques en gens associats generalment a altres trastorns. Concretament, en un d'aquestes subjectes es va identificar una mutació en homozigosi en el gen $G R N$, els defectes del qual estan associats a demència frontotemporal en estat heterozigot, i més rarament en combinació amb RP si ambdós al-lels es troben alterats. Certament, en aquest pacient s'havia referit un deteriorament cognitiu, inicialment ignorat considerant l'alta freqüència del tret en la població general, concordant amb aquest insòlit quadre clínic. D'altra banda, el tercer pacient va ser resolt com a heterozigot compost de variants en WDR19, un gen associat en major grau a una distròfia retiniana acompanyada de trastorns renals i, més rarament, a la forma aïllada del símptoma.

En l'últim dels sis casos ressaltats d'aquest objectiu es va detectar una mutació homozigota sense sentit en el gen $A S / C 5$, el paper en l'organisme del qual encara es desconeix. Amb tot, s'han correlacionat funcions visuals i auditives per a membres de la mateixa família proteica, de manera que la difusió pública d'aquest resultat és oportuna per si es donaren altres casos similars.

En conjunt, les troballes obtingudes en aquest treball avalen la importància de l'ús de les més noves tecnologies en la recerca de solucions per a malalties rares, les quals, sent realistes, presenten per ara un pronòstic terapèutic prou desemparat. Així mateix, altres conseqüències positives quant a la caracterització genètica dels pacients són la corroboració (o rectificació) del diagnòstic inicial, així com la contribució a l'estimació demogràfica i correlacions de genotip-fenotip, que en definitiva ajuden en la compressió d'USH i altres malalties relacionades. 



\section{TABLE OF CONTENTS}

ACKNOWLEDGEMENTS (Agradecimientos) ..................................................................... VII

THESIS OUTLINE ............................................................................................................................ XI

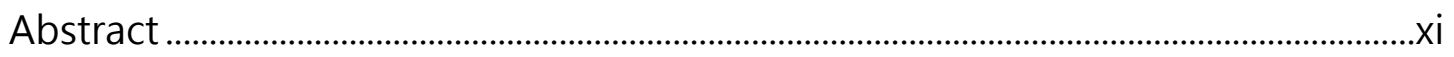

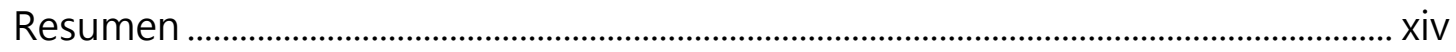

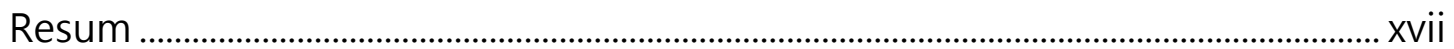

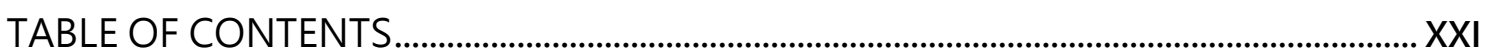

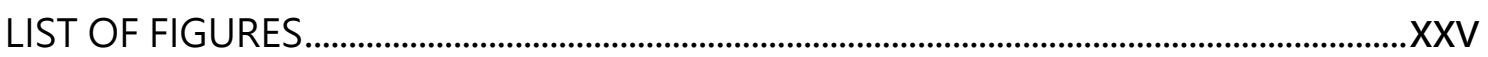

LIST OF TABLES ……………………………………………………………………………. XXVII

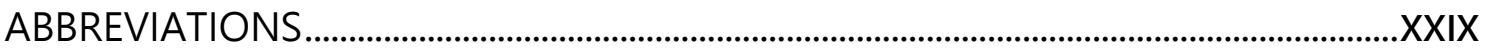

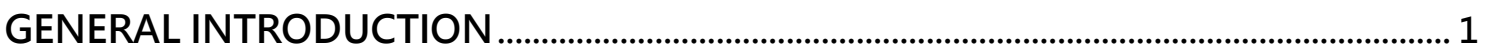

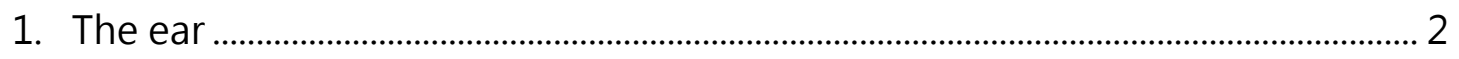

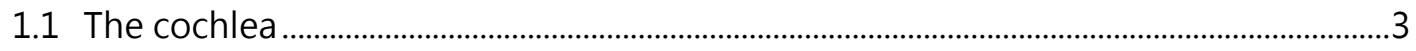

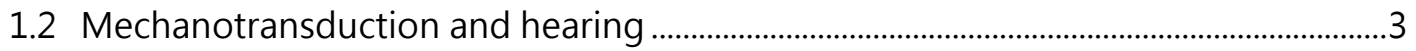

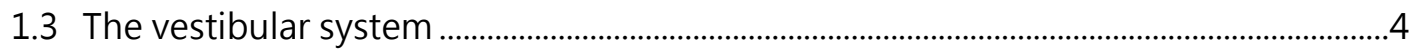

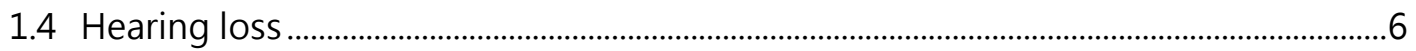

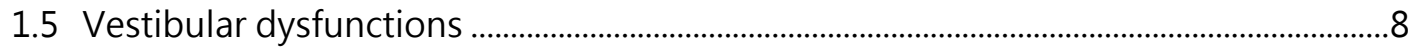

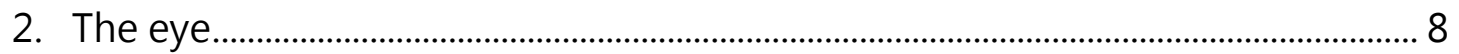

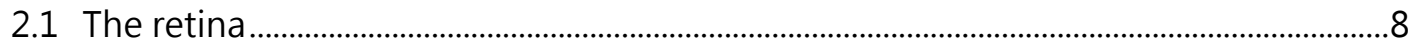

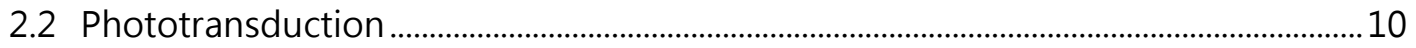

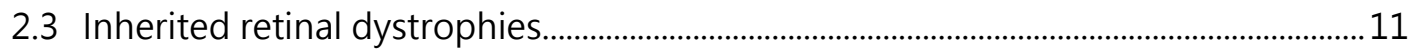

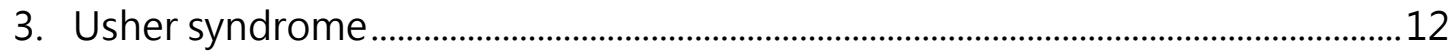

3.1 Clinical manifestations of Usher syndrome …………………........................................

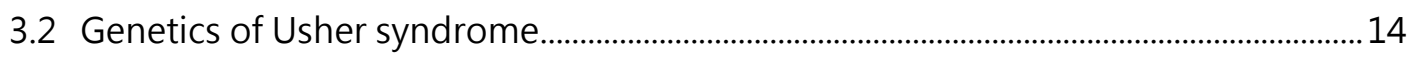

3.2.1 Genes involved in Usher syndrome type 1................................................................................. 15 


MYO7A

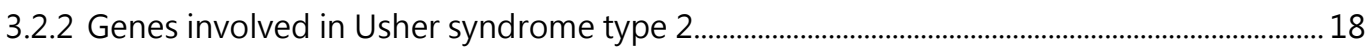

USH2A

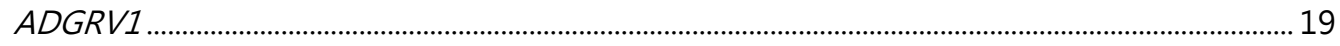

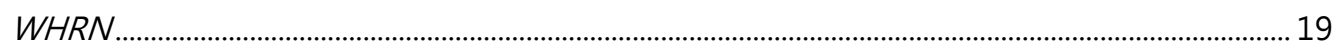

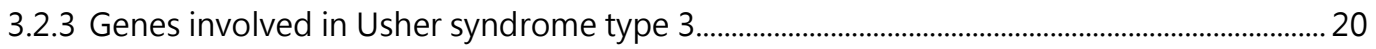

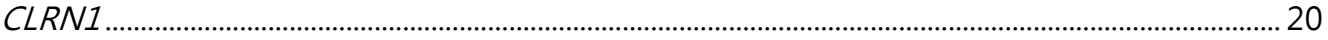

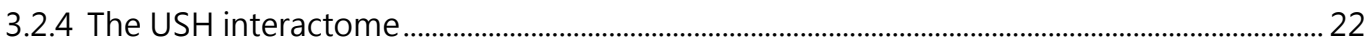

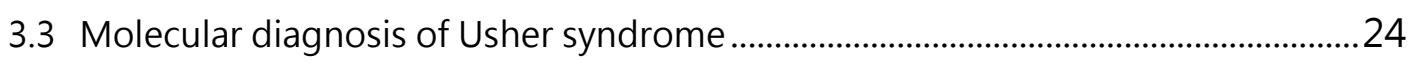

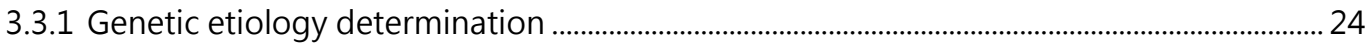

3.3.2 HTS and its application to USH diagnostics ................................................................................ 25

3.4 Therapeutic approaches for Usher syndrome .....................................................................2 27

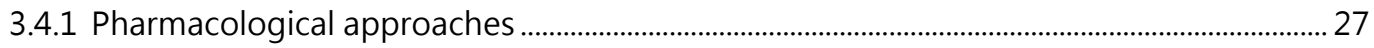

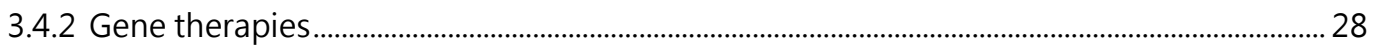

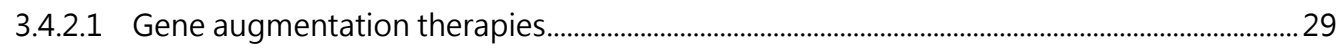

3.4.2.2 Antisense Oligonucleotides..................................................................................................................... 30

3.4.2.3 Gene editing ...................................................................................................................................... 31

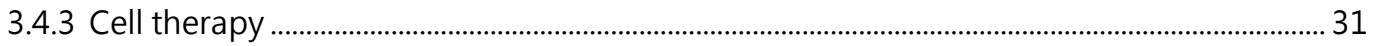

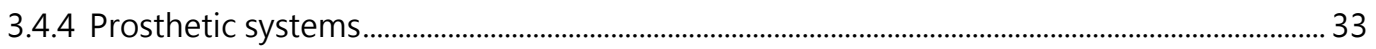

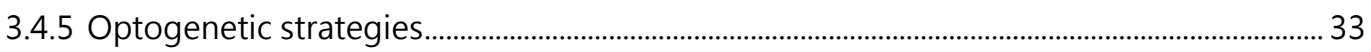

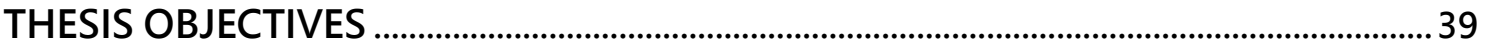

CHAPTER I: USH2A gene editing using the CRISPR system .......................................... 41

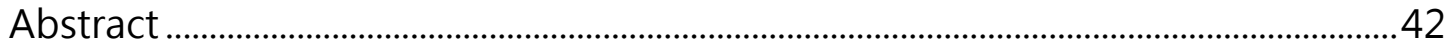

Introduction ...............................................................................................................4

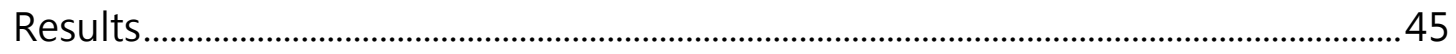

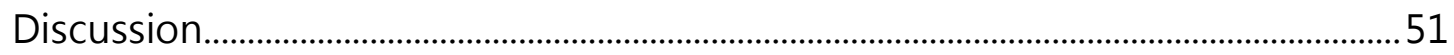

Materials and Methods ...................................................................................................5 
CHAPTER II: HTS for the molecular diagnosis of USH

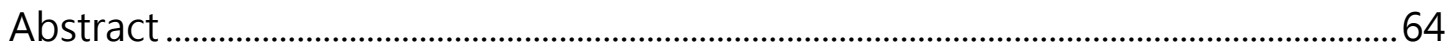

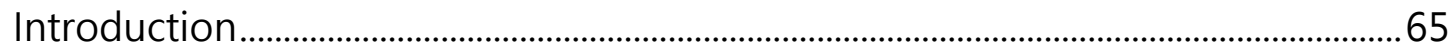

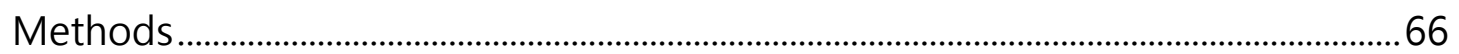

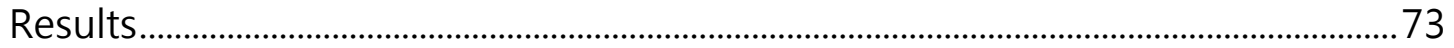

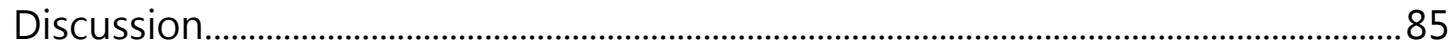

CHAPTER III: Expanding the genetic landscape of Usher-like phenotypes................. 91

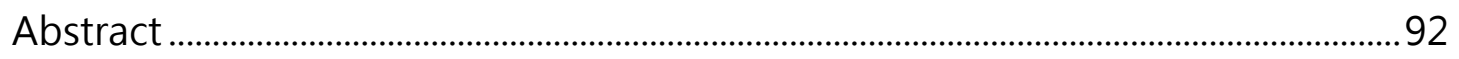

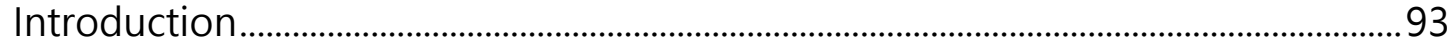

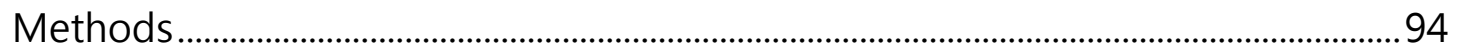

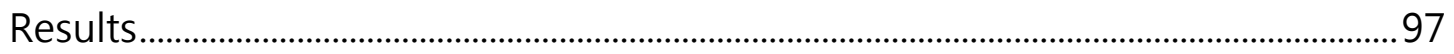

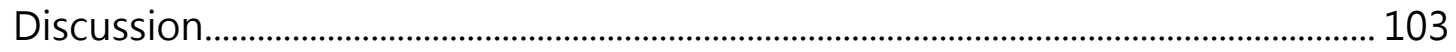

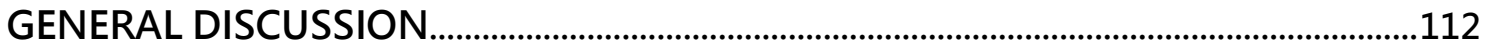

Apropos the CRISPR-based edition approach ................................................................... 112

Cas9 engineered modifications for increased on-target specificity ................................................ 113

The matter of NHEJ offshoots and predominance over ............................................................... 115

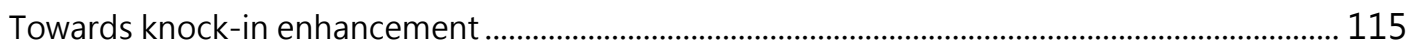

Reaching the target organ ......................................................................................................... 117

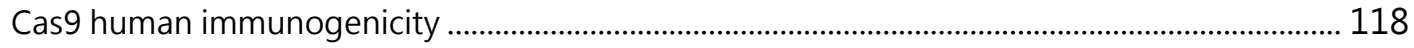

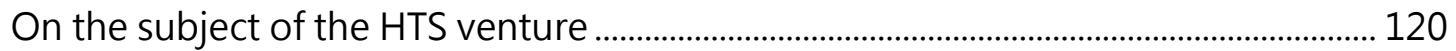

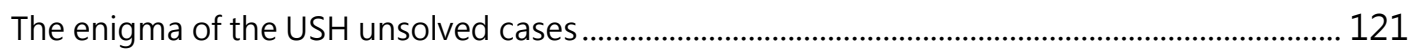

The importance of an accurate clinical assessment ........................................................................ 122

Reconsidering past and future USH genetic disclosures ................................................................ 123

CONCLUSIONS

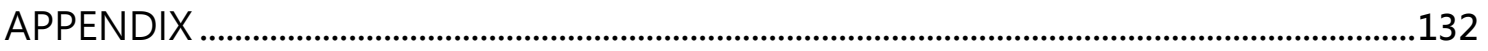

Supplementary information appertaining Chapter II .............................................................. 132

Supplementary information appertaining Chapter III................................................................. 134

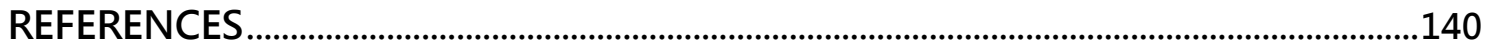





\section{LIST OF FIGURES}

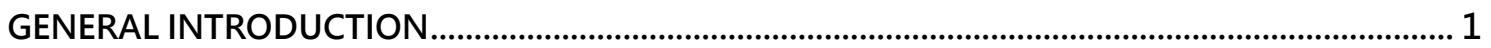

Figure 1. Anatomy of the human ear and details of the inner ear structure .............................................42

Figure 2. The vestibular labyrinth ..................................................................................................................

Figure 3. The human eye and retina .............................................................................................................. 10

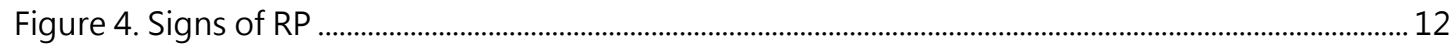

Figure 5. Schematic representation of the USH proteins as for to the longest or canonical isoforms

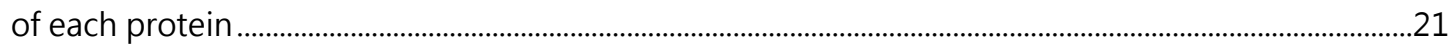

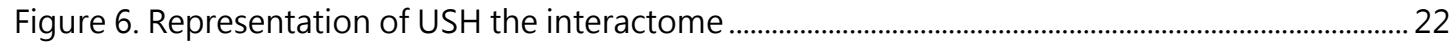

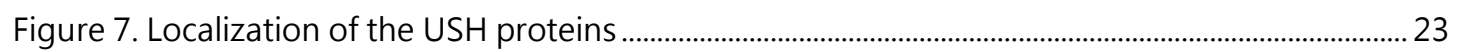

Figure 8. Schematic recapitulation of the therapeutic approaches for RP .............................................. 34

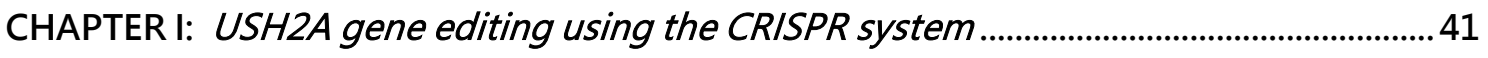

Figure 1. Diagram Showing the CRISPR Construct Designs for the USH2A Locus Editing .................. 42

Figure 2. CRISPR Assay on HEK293 Cells ...................................................................................................... 42

Figure 3. Exon 13 Is Efficiently Edited in HEK293 Cells with sgRNA-1...................................................... 42

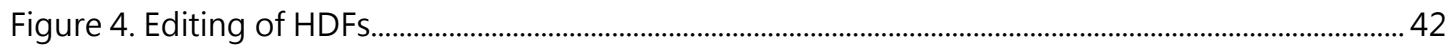

Figure 5. Deep sequencing of the HDFs transfected with RGEN-1 plus ssODN-WT ............................ 42

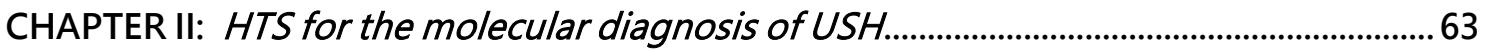

Figure 1. Recurrence of mutated genes included in the design of this study and distribution of the

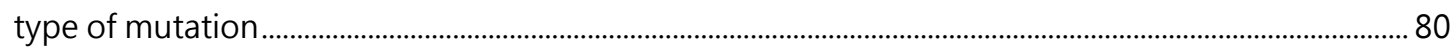

Figure 2. Minigene assay results for the four splicing mutations ................................................................ 82

Figure 3. Clinical and molecular data of patient RP1973 harboring the nonsense mutations in CEP250

CHAPTER III: Expanding the genetic landscape of Usher-like phenotypes .91

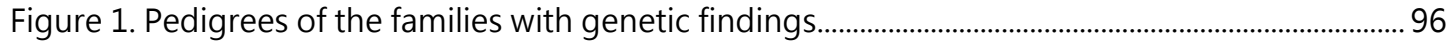

Figure 2. Audiograms from patient III:1 (FRP-426) at two different times .................................................101

APPENDIX.

Supplementary information appertaining Chapter II. 



\section{LIST OF TABLES}

GENERAL INTRODUCTION

Table 1: Summary of the different classifications of $\mathrm{HL}$.......................................................................................

Table 2: Clinical and genetic subtypes of Usher syndrome........................................................................ 14

Table 3: Summary collecting the references of most of the molecular diagnosis studies of USH based on HTS strategies, including those composing the present dissertation...................................................... 26

CHAPTER I: USH2A gene editing using the CRISPR system .................................................. 41

Table 1. Selection of in silico potential off-targets for sgRNA-1 ……………………………………………….... 50

Table 2. Locus-specific primer sequences for MiSeq deep sequencing .............................................................. 60

CHAPTER II: HTS for the molecular diagnosis of USH..

Table 1. Details of the test group formed by patients carrying previously detected variants in USH genes.

Table 2. Details of the target region studied in this study.

Table 3. Causative mutations and putative pathogenic variants identified in this study 74

Table 4. Summary of the bioinformatics predictions for the novel causative putative mutations detected in this study...

CHAPTER III: Expanding the genetic landscape of Usher-like phenotypes .91

Table 1: Clinical phenotype of the subjects presenting with symptoms .98

Table 2: Variants of interest found in this study.

APPENDIX. . .132

Supplementary information appertaining Chapter III

Supplementary Table 1: Assessment of the missense variants using conservation algorithms......134

Supplementary Table 2: Alignments and conservation across different species for the amino acid changes

Supplementary Table 3: Pathogenicity assessment of the novel variants according to ACMG guidelines 134 



\section{ABBREVIATIONS}

$1000 \mathrm{~g} 1000$ Genomes Project (International Genome Sample Resource)

53BP1 p53 binding protein 1

AAV adeno-associated virus

aCGH microarray-based comparative genomic hybridisation

ACMG American College of Medical Genetics and Genomics

AD Alzheimer's disease

AON antisense oligonucleotides

ARRP autosomal recessive RP

BCVA best-corrected visual acuity measurements

Cas9 CRISPR associated protein 9

CC connecting cilium

cDNA complementary DNA

CES clinical exome sequencing

cGMP cyclic guanine monophosphate

ChR2 channelrhodopsin 2

CNTF ciliary neurotrophic factor

CNV copy number variation

CRISPR clustered regularly interspaced short palindromic repeats

crRNA crispr RNA

dB decibel

dbSNP Database of Single Nucleotide Polymorphisms

dCas9 dead Cas9

DMEM Dulbecco's Modified Eagle Medium

DMOG dimethyloxaloglycine

DNA deoxyribonucleic acid

DSB Double-stranded break

EDTA ethylenediamine tetraacetic acid

ERDC European Retinal Disease Consortium

ESC embryonic stem cell

ESE exonic splicing enhancers

ExAC Exome Aggregation Consortium

FAF fundus autofluorescence

FTD frontotemporal dementia

gDNA genomic DNA

GFP green fluorescent protein 


\begin{tabular}{|c|c|}
\hline gonmAD & Genome Aggregation Database \\
\hline gRNA & guide RNA \\
\hline GWAS & Genome-wide association studies \\
\hline Hd-Ads & helper-dependent adenoviruses \\
\hline HDF & human dermal fibroblast \\
\hline HDR & homology directed repair \\
\hline HEK293 & human embryonic kidney 293 \\
\hline HGMD & Human Gene Mutation Database \\
\hline $\mathrm{HL}$ & hearing loss \\
\hline HR & homologous recombination \\
\hline HTS & high-throughput sequencing \\
\hline $\mathrm{IHC}$ & inner heair cells \\
\hline indel & insertion/deletion \\
\hline iPSC & induced pluripotent stem cell \\
\hline IRD & Inherited reitnal dystrophy \\
\hline IS & inner segment \\
\hline IVT & in vitro transcripted \\
\hline LOVD & Leiden Open Variation Database \\
\hline MAF & minor allele frequency \\
\hline MLPA & multiplex ligation-dependent probe amplification \\
\hline mRNA & messenger RNA \\
\hline NACA & N-Acetylcysteine Amide \\
\hline nCas9 & nickase Cas9 \\
\hline $\mathrm{NCL}$ & neuronal ceroid lipofuscinosis \\
\hline NGF & nerve growth factor \\
\hline NGS & next generation sequencing \\
\hline NHEJ & non-homologous end joining \\
\hline $\mathrm{NIH}$ & National Institute of Health \\
\hline $\mathrm{NpHR}$ & halorhodopsin \\
\hline nsHL & non-syndromic hearing loss \\
\hline nsRP & non-syndromic retinitis pigmentosa \\
\hline OCT & optical coherence tomography \\
\hline $\mathrm{OHC}$ & outer hair cells \\
\hline OMIM & Online Mendelian Inheritance in Man \\
\hline ONT & Oxford Nanopore Technology \\
\hline OS & outer segment \\
\hline PacBio & Pacific Biosciences \\
\hline PAM & protospacer adjacent motif \\
\hline
\end{tabular}




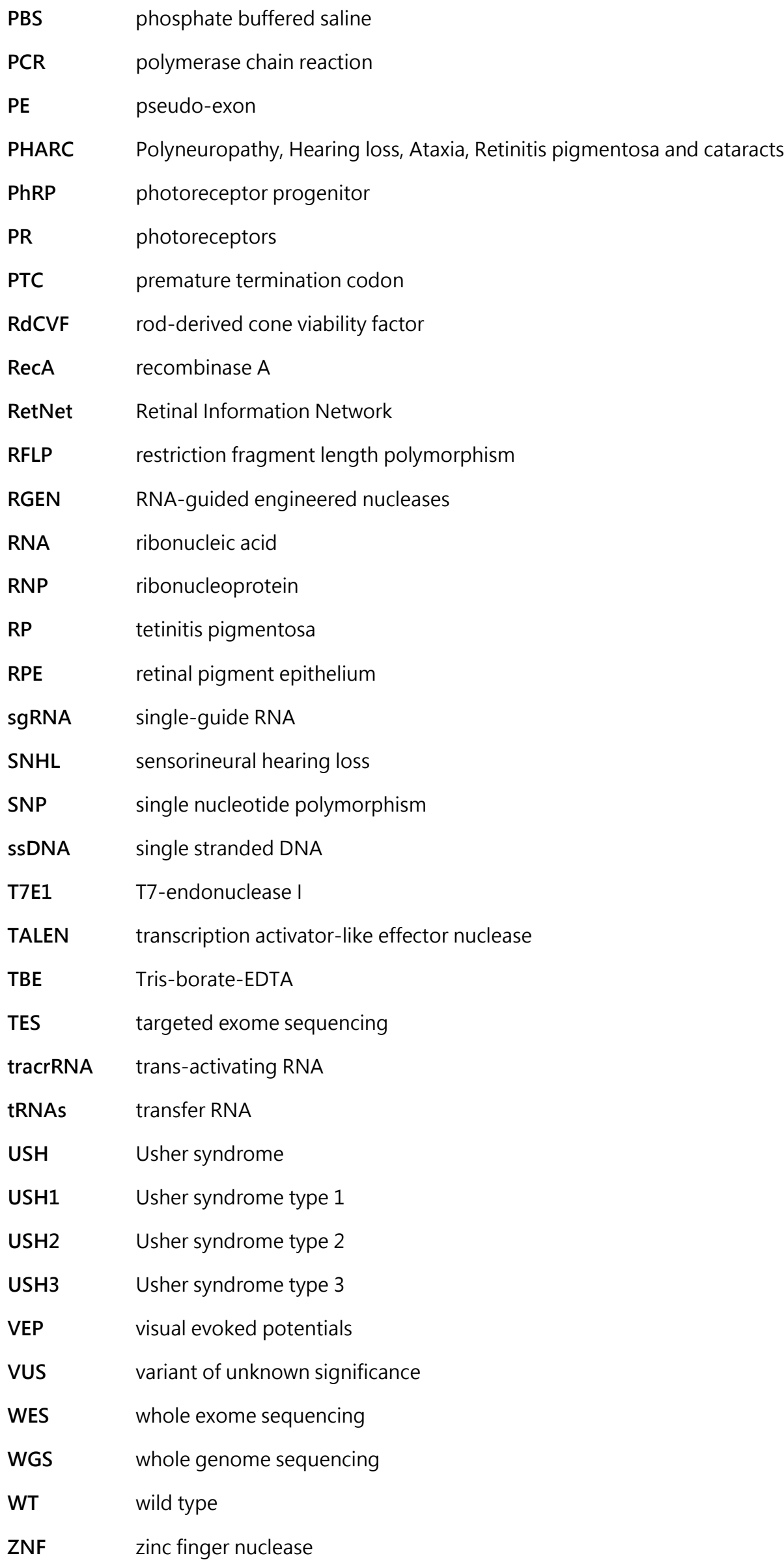





GENERAL INTRODUCTION 


\section{GENERAL INTRODUCTION}

We live in a time in which media communication is a hallmark, at least for the population living in developed countries. Therefore, social integration and professional success greatly rely on it. Sight and hearing are the senses that engage most with the surroundings. Thus, the synchronic hampering of both functions has grave repercussions on the life of the patients, which, depending on the severity and age of onset of the symptoms, can include self-sufficiency determent and even intellectual development hindrance. As such, Usher syndrome (USH) is the most common deafblindness disorder of genetic origin, characterized by sensorineural hearing loss $(\mathrm{SNHL})$ and a retinopathy that causes progressive vision detriment.

Regardless of the obvious hampering features, the patients are also prone to suffer psychological consequences, precisely because of these physiological disabilities and the course of the disease. It must be considered that this disorder starts with the hearing defect to be followed years later by the vision loss, meaning that the subject has to deal with another predicament after already having come to terms with the initial shock. To make matters worse, the patients must confront the disheartening reality that USH is a rare disease for which no cure is available to date.

For these reasons and albeit the low frequency among the population, more research on the early diagnosis and therapeutic advances for USH is worthwhile, and the current dissertation delves into both topics.

\section{The ear}

The ear is the organ responsible for translating the sound waves into electric stimuli that are later conveyed to the brain, as well as for balance and spatial orientation. It presents three main divisions (Figure 1):

- The outer ear, which has the function of collecting and conducting the sound. It consists of the pinna (auricle) and the ear canal, and beyond is the tympanic membrane (eardrum). Aside from separating the outer from the middle ear, the latter has the function of transforming the sound waves into vibrations. 
- $\quad$ The middle ear, which consists of the three small bones responsible for amplifying and transmitting the sound vibrations received from the eardrum. These articulated ossicles are the malleus, the incus and the stapes. The eustachian tube can also be found from this part of the ear on, which is a canal connecting the middle ear to the back of the nose and serves to compensate the pressure with the outer atmosphere.

- The inner ear, which is the deepest part of the ear and comprises the cochlea and the vestibular apparatus, preceded by the oval window. The cochlea is a spirally shaped organ with the receptor cells for hearing, whereas the vestibule and semicircular canals are needed for the balance.

\subsection{The cochlea}

The cochlea is a snail-like structure internally divided in three compartments by membranes and filled with fluid. The scala vestibuli and the scala tympani are both filled with perilymph, whereas the scala media (or cochlear duct) is filled with endolymph. The scala media is separated from the scala tympani by the basilar membrane, on top of which rests the organ of Corti that contains the two types of sensory hair cells and other supporting cells. The inner hair cells $(\mathrm{IHC})$ and outer hair cells $(\mathrm{OHC})$ are the protagonists of the hearing function. Though differently arranged, both present stereocilia, which are interlinked microvilli in the apical surface that together form the hair bundle and are connected to a gelatinous matrix known as the tectorial membrane (Figure 1). Sensitivity to different frequencies depends on the location of the hair cells along the basilar membrane, being those positioned throughout the apical end sensible to low frequencies and those present near the basal region responsive to higher frequencies.

\subsection{Mechanotransduction and hearing}

Mechanotransduction refers to the process of converting a physical stimulus, in this case acoustic, into an electrical signal.

The hearing process starts when the sound waves are collected by the outer ear and reach the eardrum, producing vibrations that are conveyed to the cochlea via the ossicles and across the oval window. This oscillation in the basilar membrane leads to the displacing of the hair bundles in relation to the tectorial membrane, and the motion produces the mechanical opening of the ion channels of the stereocilia. As a result, calcium and potassium ions permeate from the endolymph into the hair cell and ultimately cause the release of 
neurotransmitters at its synaptic base, which propagate to the dendritic endings of vestibulocochlear nerve and the electrical signal is further transmitted to the brain. It is believed that the IHCS are the main sensory cells that transmit the auditory signal to the brain, whereas the $\mathrm{OHC}$ are essential for vibration amplification by increasing the amplitude and frequencies of the low sound pressure levels, a property known as electromotility (Richardson et al. 2011, Ashmore 2018).

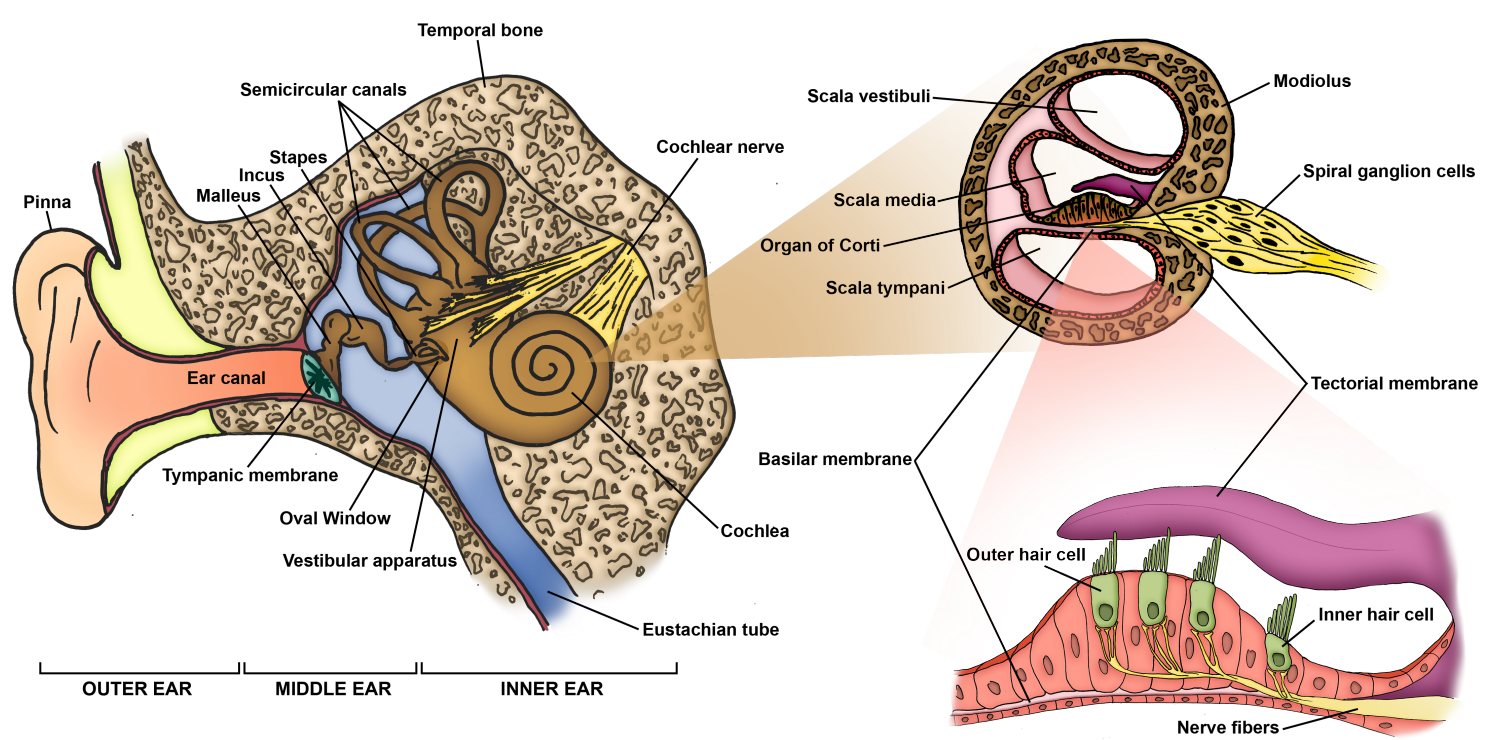

Figure 1. Anatomy of the human ear and details of the inner ear structure.

\subsection{The vestibular system}

Apart from the hearing process, the inner ear is also responsible for the perception of motion, spatial orientation and head position, which are critical for balance and body stabilization. The vestibular labyrinth, continuous with the cochlea and also filled with endolymph, is the part of the inner ear that enables these functions (Figure 2A). In this section, the semicircular canals sense rotational movements, whereas the otolith sensors are in charge of detecting linear acceleration and gravitational forces (Figures 2B and 2C).

There are three semicircular canals, each one set in a different plane and responsible for sensing a particular head direction, and ending in the ampulla, which is a bulbous expansion at the end of each of these tubes. This part of dilated duct contains the sensory epithelium composed of the hair cells, known as the crista ampullaris, and the cupula, which is a gelatinous matrix damming up the fluid and encasing the stereocilia of the hair cells. A given movement displaces the endolymph of the pertinent semicircular canal towards the 
ampulla, where the hair cells are current swayed by the force of the current across the cupula, consequently conveying a signal to the appended vestibulocochlear nerve.

The otolith organ is composed of the saccule and the utricle, which are able to sense movement in the vertical and horizontal plane, respectively. Hair cells in these structures are covered by a horizontal membrane that presents otoconia (calcium carbonate crystals) on it, exerting a load pressure. Movements and gravitational forces displace and/or increase the weight differentially upon the stereocilia of the sensory cells, subsequently sending a signal to the brain.

The general proprioceptive notion is due to the integration of these sensory inputs from the vestibular system with other perception data such as visual, motor-related or somatosensory signals.

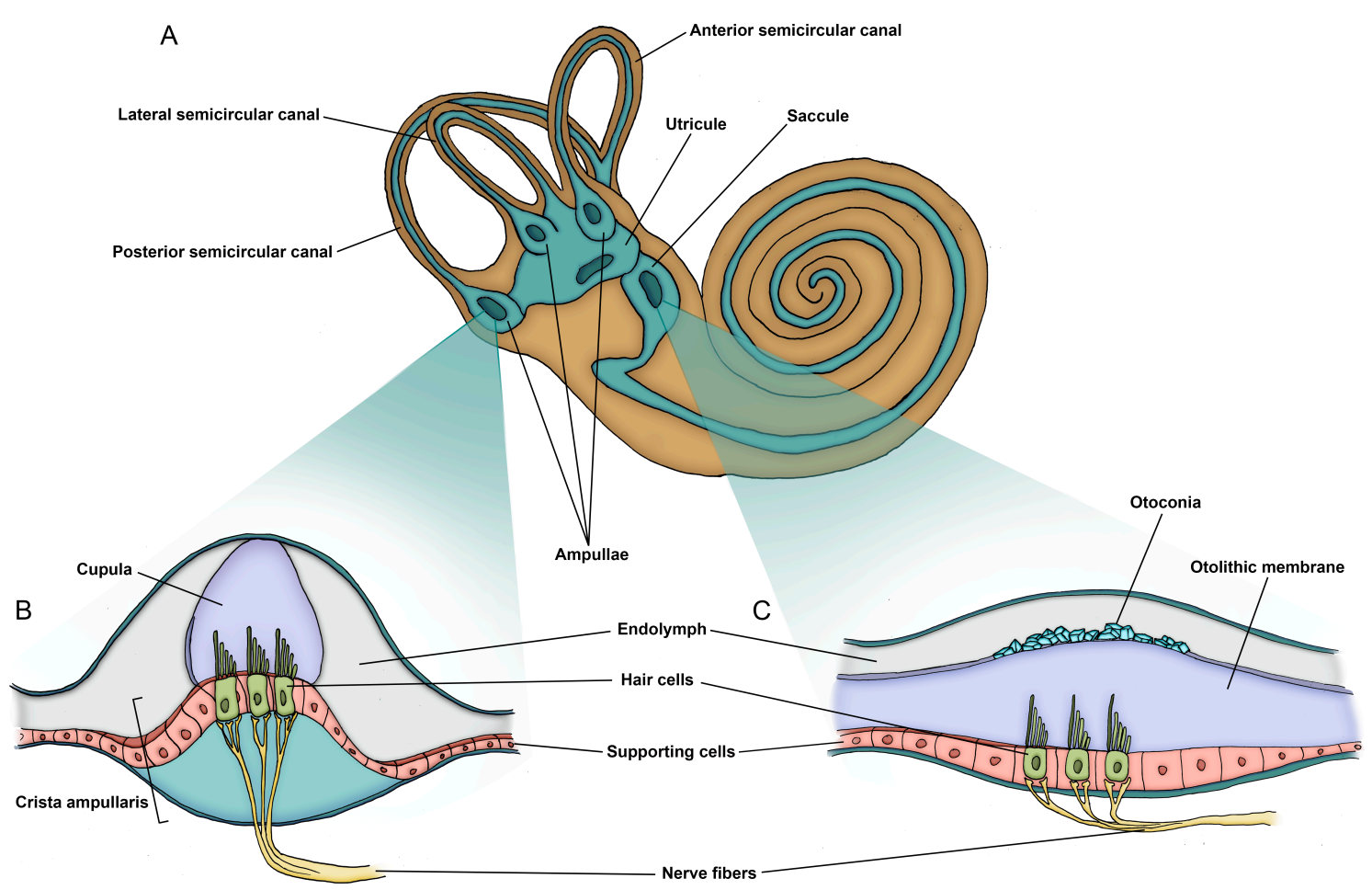

Figure 2. The vestibular labyrinth. (A) Simplified structure of the inner ear, including the vestibular system and cochlea. (B) Schematic representation of the sensory tissue in the semicircular canals of the ampullae and (C) in the otolithic organ (the utricle and the saccule). 


\subsection{Hearing loss}

Hearing Loss $(\mathrm{HL})$ connotes a partial or total deficit in the hearing ability, in the latter case then referred as deafness. The impairment can debut at any age and occur in one (unilateral) or both ears (bilateral). $\mathrm{HL}$ is estimated to affect one in every 1000 newborns (Fortnum et al. 2001), yet the number increases with age to approximately $5 \%$ of the whole living population, according to the World Health Organization. There are several classification standards depending on the criteria (Table1):

\section{Severity}

The diagnosis of hearing loss $(\mathrm{HL})$ is commonly detected through a pure tone audiometry, the criteria based on decibels $(\mathrm{dB})$ required for tone detection amidst a frequency range. Hearing is considered normal when perception thresholds are of $25 \mathrm{~dB}$ or lower; thereupon, hearing loss is categorized as mild ( 25 to $40 \mathrm{~dB}$ ), moderate (40 to $70 \mathrm{~dB}$ ), severe (70 to 90 $\mathrm{dB}$ ) and profound (>90 dB).

\section{Age of onset}

$\mathrm{HL}$ can be classified as prelingual, when the symptom is congenital or manifests before speech development, or postlingual, if it starts after the individual learns to talk.

\section{Course}

If the degree of tone perception does not suffer more decay in the course of the lifetime, $\mathrm{HL}$ is referred to as stable, otherwise it is considered to be progressive.

Type or damaged region

Anomalies involving outer or middle ear that affect the transmission of the sound vibrations produce conductive HL. When there is a sensory or neural problem, meaning either the inner ear or vestibulocochlear nerve are compromised, hearing loss is considered to be sensorineural. Furthermore, a third possibility where there is a combination of both types is known as mixed $\mathrm{HL}$.

\section{Etiology}

Depending on the inducing factors, hearing loss can be:

- Acquired, when it is produced by environmental causes such as trauma, ototoxic drugs, infections, noise exposure, aging, etc.

- Genetic, accounting for around $60 \%$ of the cases, when it is due to mutations in the genome and it is usually inheritable (Raymond et al. 2019). There are 152 deafnessassociated genes known to date according to the Deafness Variation Database 
(accessed October 2019), which present several inheritance patterns such as autosomal recessive, autosomal dominant, $\mathrm{X}$-linked, or mitochondrial. Besides, $70 \%$ of the inherited cases of $\mathrm{HL}$ are non-syndromic ( $\mathrm{nsHL}$ ), meaning the symptom is presented isolated. The rest are syndromic accompanied by other signs, as in Usher syndrome (Hoefsloot et al. 2014).

Table 1: Summary of the different classifications of $\mathrm{HL}$

\begin{tabular}{|c|c|c|c|c|}
\hline Criteria & Type & \multicolumn{3}{|c|}{ Description } \\
\hline \multirow{4}{*}{ Severity } & Mild & \multicolumn{3}{|l|}{ At 25 to $40 \mathrm{~dB}$} \\
\hline & Moderate & \multicolumn{3}{|l|}{ At 40 to $70 \mathrm{~dB}$} \\
\hline & Severe & \multicolumn{3}{|l|}{ At 70 to $90 \mathrm{~dB}$} \\
\hline & Profound & \multicolumn{3}{|l|}{ At $>90 \mathrm{~dB}$} \\
\hline \multirow{2}{*}{ Course } & Stable & \multicolumn{3}{|c|}{ The degree of $\mathrm{HL}$ remains the same throughout the lifetime of the patient } \\
\hline & Progressive & \multicolumn{3}{|c|}{ The hearing impairment aggravates over time } \\
\hline \multirow{3}{*}{$\begin{array}{l}\text { Frequencies } \\
\text { compromised }\end{array}$} & Low & \multicolumn{3}{|l|}{$<500 \mathrm{~Hz}$} \\
\hline & Medium & \multicolumn{3}{|l|}{$500-2000 \mathrm{~Hz}$} \\
\hline & High & \multicolumn{3}{|l|}{$>2000 \mathrm{~Hz}$} \\
\hline \multirow{2}{*}{ Onset } & Prelingual & \multicolumn{3}{|c|}{ Either congenital or acquired before speech development } \\
\hline & Postlingual & \multicolumn{3}{|c|}{ Ocurring after the development of the use of language } \\
\hline \multirow{3}{*}{ Localization } & Conductive & \multicolumn{3}{|c|}{ Defects in the outer/middle ear } \\
\hline & Sensorineural & \multicolumn{3}{|c|}{ Defects in the inner ear and inwards } \\
\hline & Mixed & \multicolumn{3}{|c|}{ Combined conductive and sensorineural $\mathrm{HL}$} \\
\hline \multirow{7}{*}{ Etiology } & $\begin{array}{l}\text { Acquired } \\
\text { (40\%) }\end{array}$ & \multicolumn{3}{|c|}{ Enviromental causes (infections, trauma, ototoxic drugs, etc) } \\
\hline & \multirow{6}{*}{$\begin{array}{c}\text { Genetic } \\
(60 \%)\end{array}$} & \multirow{2}{*}{$\begin{array}{c}\text { As the } \\
\text { phenotype }\end{array}$} & $\begin{array}{c}\text { Non-syndromic } \\
(70 \%)\end{array}$ & $\mathrm{HL}$ is the only symptom \\
\hline & & & $\begin{array}{c}\text { Syndromic } \\
\text { (30\%) }\end{array}$ & $\begin{array}{l}\mathrm{HL} \text { accompanied by additional } \\
\text { symptoms in other organs }\end{array}$ \\
\hline & & \multirow{4}{*}{$\begin{array}{l}\text { As the } \\
\text { inheritance pattern }\end{array}$} & $\begin{array}{l}\text { Autosomal dominant } \\
\qquad(20 \%)\end{array}$ & One altered allele required \\
\hline & & & $\begin{array}{l}\text { Autosomal recessive } \\
\text { (75-80\%) }\end{array}$ & Two altered alleles required \\
\hline & & & $\begin{array}{l}\text { X-linked } \\
(2-5 \%)\end{array}$ & Dominant manifestation in males \\
\hline & & & $\begin{array}{l}\text { Mitochondrial } \\
(<1 \%)\end{array}$ & $\begin{array}{l}\text { Mitochondrial chromosome origin. } \\
\text { Prone to manifest a dominant or } \\
\text { mosaic-like pattern }\end{array}$ \\
\hline
\end{tabular}




\subsection{Vestibular dysfunctions}

In accordance with the function of the organ, bilateral vestibular hyporeflexia or areflexia results in balance problems, typically enhanced under unfavorable conditions such as darkness or uneven surfaces, displayed as clumsiness or even gait difficulties. Depending on the degree of the impairment, additional aggravating features can manifest, such as vertigo and dizziness. The latter is due to oscillopsia, which consists in a visual disturbance where objects within the visual field are perceived to be moving, as a consequence of the collapse of the vestibulo-ocular reflex, which is in charge of vision stabilization during motion.

When the condition is congenital, the derived imbalance can delay the development of motor abilities like walking, which is a hallmark of USH patients that have the vestibular function altered.

\section{The eye}

The sense of sight is the capacity to perceive our surroundings, including objects, colors, depth or brightness, the awareness of the latter being also important for the circadian rhythms. The eye is the organ that enables the reception of the visual information, to be processed afterwards by the nervous system. The ocular globe consists of three concentric layers (Figure 3A):

- The outer layer (fibrous tunic), which comprises the sclera on the posterior side and the cornea on the anterior pole, with the limbus being the transition border of both tissues.

- The middle layer (vascular tunic), also known as uvea, which includes three sections, namely the iris, the ciliary body, and the choroid.

- The inner layer (sensory tunic), which consists of the retina.

\subsection{The retina}

The retina is the photosensitive section of the eye with the purpose of receiving the light and converting it to neural signals that are transmitted to the brain to be interpreted as a visual image. This $\sim 200 \mu \mathrm{m}$ thin tissue presents several cell layers composed of the retinal pigment epithelium (RPE) and a stratum of different interconnected neurons, among which the photoreceptors can be found (Figure 3B). 
There are two types of photoreceptors, the rods and the cones, whose distribution among the retina differs significantly. Rods are more abundant and outnumber the cones by an approximate 20:1 ratio. Cones are condensed in the central region of the retina (macula) and account for the visual acuity, especially in the fovea, which is the small core of the macula exclusively populated by this type of photoreceptor. The density of cones decreases towards the periphery of the retina, where rods become predominant.

Rods are the cylindrically shaped cells responsible for the black and white perception and specialized for low-light conditions (scotopic vision). They contain the visual pigment rhodopsin for this purpose. The conically shaped cones are color sensitive and more active under higher light levels (photopic vision). These cells present different types of photopsin as photopigment, depending on the wavelength they respond to (red, green or blue spectrum). Despite the shape and distribution differences, both rods and cones exhibit the same structuring, primarily consisting of outer segment (OS), connecting cilium (CC) and inner segment (IS).

The OS is a specialized primary cilium, composed of stacked membranous discs containing the photopigment. It is continuously being renewed, since the discs steadily peel off from the apical region and are phagocytosed by the RPE, which is in direct contact with this section. The IS presents the nucleus and organelles of the cell, as well as the synaptic terminal region. The CC is a thinner junction between both segments that enables the intracellular trafficking of vesicles and other metabolites, important for the reposition of the outer segment discs. In addition, the base of the OS encircled by the calyceal processes, which are microvillus-like structures that project from the apical end of the IS.

Apart from the photoreceptors, the retina features other cell types, distributed among three nuclear and two plexiform layers that are essential for the transmission of the visual stimulus (Figure 3B). 
A

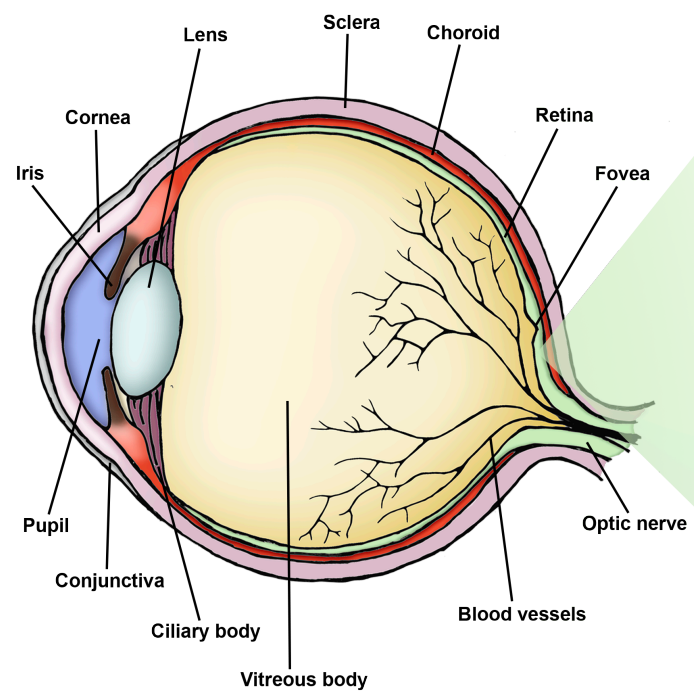

B

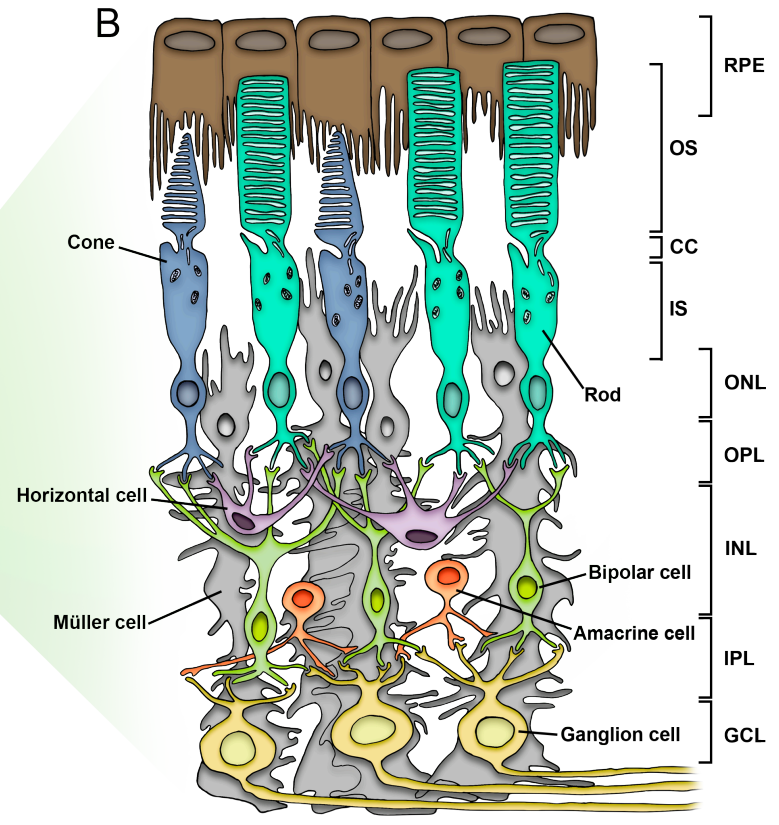

Figure 3. The human eye and retina. (A) Depiction of the structure of the ocular globe. (B) Cellular composition of the retina forming the distinct layers. Bipolar cells connect the photoreceptors with the ganglion cells, whose axons extend towards the optic disc (optic nerve head) and conform the retinal nerve fiber layer. Horizontal and amacrine cells link the adjacent photoreceptors and ganglion cells, respectively. The calyceal processes localize at the periciliary region. Abbreviations: RPE, Retinal Pigment Epithelium; OS, Outer Segment; CC, Connecting Cilium; IS, Inner Segment; ONL, Outer Nuclear Layer; OPL, Outer Plexiform Layer; INL, Inner Nuclear Layer; IPL, Inner Plexiform Layer; GCL, Ganglion Cell Layer.

\subsection{Phototransduction}

The phototransduction is the mechanism by which the collected light from the environment is transmuted to an electrical signal in the retina, to be interpreted in the brain as visual images. The photopigments in the OS of the photoreceptors are composed of an opsin, a membrane protein, and a chromophore, the 11-cis-retinal. The process starts when this latter light-sensitive molecule absorbs a photon leading to its isomerization into 11trans-retinal, producing a conformational change of the photopigment that triggers a signaling cascade that results in the hydrolysation of cyclic guanine monophosphate (cGMP). This involves a decrease in cGMP, which in turn produces the sealing of the ion channels and, consequently, a hyperpolarization of the membrane that affects the release of neurotransmitters in the photoreceptor basal region where the synapsis occurs. The 11trans-retinal is then converted back into 11-cis-retinal in the RPE for its reuse in the visual cycle as it is released again to the OS of the photoreceptor. 


\subsection{Inherited retinal dystrophies}

Inherited retinal dystrophies (IRDs) refer to all genetic disorders that involve vision loss due to the dysfunction of the retinal cells. All the IRDs together compute for a prevalence of 1 in 2000 people (Berger et al. 2010), yet individually they are rated as rare diseases (Farrar et al. 2017). Almost all of these diseases are monogenic following an autosomal recessive, autosomal dominant or X-linked inheritance pattern (Verbakel et al., 2018). There are some exceptions for a few reports on mitochondrial and digenic traits, or even on modifier genes (Farrar et al. 2017). There are up to 271 associated genes described to date for syndromic and non-syndromic IRDs (RetNet, accessed October 2019).

The most common IRD is retinitis pigmentosa (RP), characterized by progressive vision loss as a result of the death of the rods and eventually of the cones, with a worldwide prevalence of 1 in every 4000 (Hartong et al. 2006). Since rods are the first cells to deteriorate, the first sign of RP is night blindness (nyctalopia) and then loss of peripheral vision (tunnel vision). There is a gradual constriction of the visual field until cones also start to degenerate, finally resulting in a decrease of the visual acuity. The most severe cases can end in complete blindness due to the collapse of central vision. During the course of the disease, patients usually manifest other symptoms such as photophobia (light sensitivity), color vision deficiency and photopsia (perception of light flashes).

In regard to the physiological symptoms, the typical features of the disorder are displayed as eye fundus abnormalities that include attenuation of retinal vessels, waxy pallor of the optic nerve, and peripheral pigmentary alterations after which the disease is named. These show up as pigment clumps either with a granular patters or bone-spicule appearance (Figure 4).

Most of the cases of RP are non-syndromic (nsRP), however, about 20-30\% correspond to syndromic forms such as Usher syndrome, Bardet-Biedl syndrome or Joubert syndrome (Verbakel et al. 2018). 

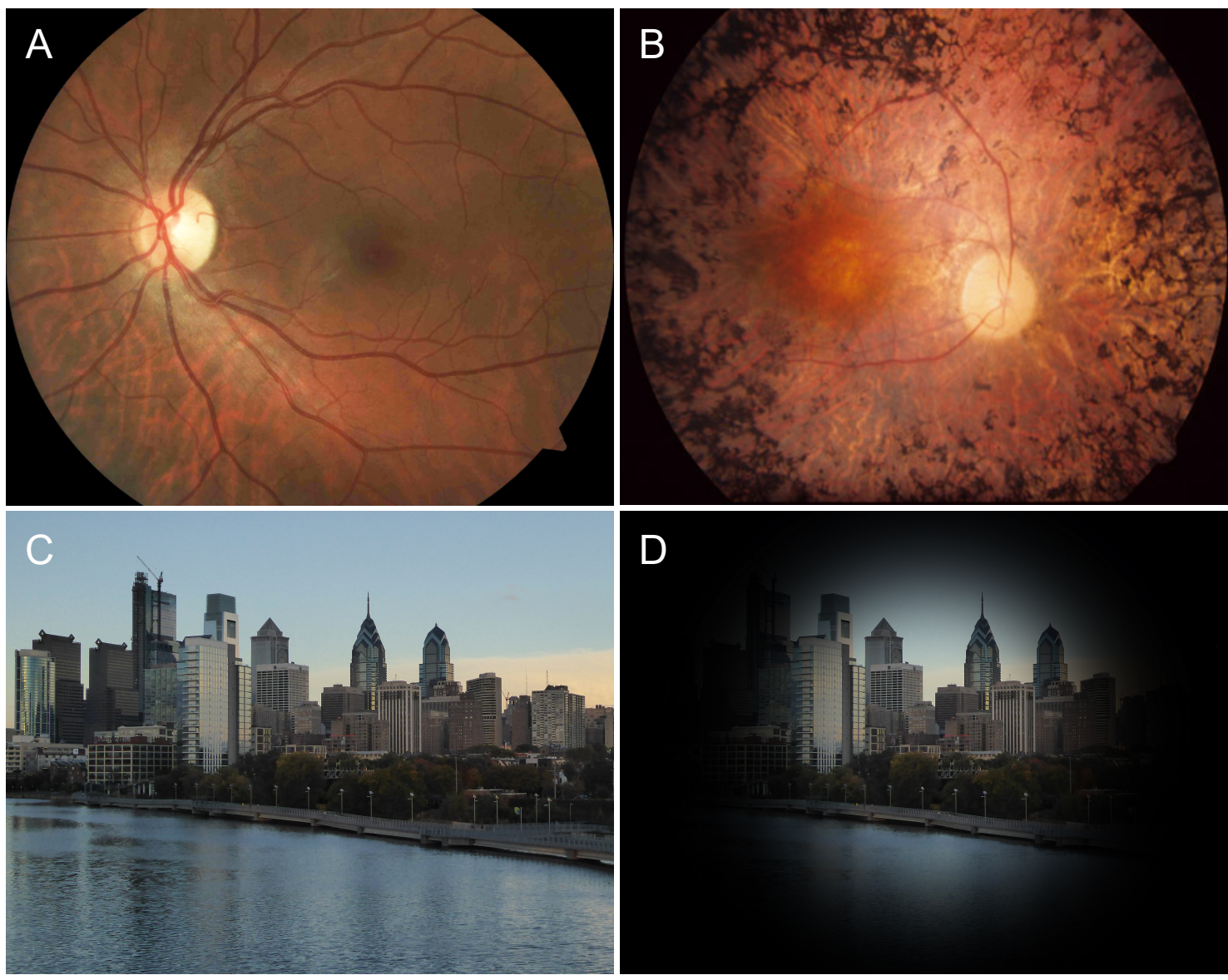

Figure 4. Signs of RP. Eye fundus images of (A) a healthy individual and (B) an RP patient. A typical feature of the retinal atrophy is the presence of pigment clumps (or bone-like spicules pigments) starting in the periphery, thinning of the blood vessels, and optic nerve pallor. Representation of normal (C) and RP-derived tunnel vision (D). (Image B obtained and modified from www.eyewiki.aao.org).

\section{Usher syndrome}

Usher syndrome (USH) is an autosomal recessive disease, characterized by sensorineural hearing loss (SNHL), retinitis pigmentosa (RP) and, in some cases, vestibular dysfunction. The association of RP and hearing impairment was first detected by the German ophthalmologist Albrecht von Gräfe back in 1858, but it was not until 1935 that Charles Usher, after whom the disease was named, introduced the disorder as hereditary based on his observations in several families (von Gräfe 1858, Usher 1935). The clinical subcategorization of the syndrome was not introduced for almost another six decades (Smith et al. 1994), and one year later the first causative gene was identified (Weil et al. 1995).

USH is the most common genetic disorder combining visual and hearing impairment, accounting for more than $50 \%$ of the deafblindness cases, and with a general prevalence ranging from 3.2 to $6.2 / 100,000$ people, which depends on the studied population (Millán et al. 2011). 
This disease is considered to be a ciliopathy, which is a group of pathologies that arise from defects in genes that somehow participate in the structure or signaling of cilia, as in the stereocilia of the IHC or the CC of the photoreceptors (Sorusch et al. 2014). Since many tissues present cilia, any genetic alteration involved in their function is susceptible of affecting several organs. Consistently, some studies in USH patients and animal models have reported additional symptoms related to ciliary functions, such as bronchiectasis (Bonneau et al. 1993), reduced sperm motility (Hunter et al. 1986), olfactory loss (Zrada et al. 1996, Ribeiro et al. 2016), lower nasal ciliary beat frequency (Aparisi et al. 2013), somatosensory deficit (Frenzel et al. 2012, Moshourab et al. 2017) and nociception (Ciardo et al. 2016). These findings have not been explored further and should therefore be cautiously taken; more research is needed before accepting them as comorbidities of USH.

\subsection{Clinical manifestations of Usher syndrome}

USH is categorized into three subtypes based on the severity, onset and progression of the disease (Table 2) (Davenport and Omenn 1977).

Usher syndrome type 1 (USH1) is the most severe form of the disorder and reckons for approximately one third of all the USH cases (Petit 2001). Patients present with severeprofound prelingual $\mathrm{HL}$, an early RP onset usually within the first decade of life, and vestibular areflexia.

Usher syndrome type 2 (USH2) is the most frequent category, accounting for almost two thirds of all cases (Millán et al. 2011). It is characterized by moderate-severe prelingual hearing impairment, a pubertal onset of RP, and normal vestibular function.

The rarest form of USH is type 3 (USH3). However, this subtype has a greater incidence in the Finnish and Ashkenazi Jewish populations due to a founder effect, where the proportion of cases reach 40\% (Pakarinen et al. 1995, Ness et al. 2003). USH3 patients display a postlingual progressive $\mathrm{HL}$, whereas the RP age of onset and the vestibular function alteration are variable.

Some patients do not meet the hallmarks of these three subtypes. Thus, they are categorized as atypical USH cases. Furthermore, even within the well-defined subtypes, some patients manifest slight variations of the symptoms, suggesting that they are rather on a continuum that will be clarified as more phenotype-genotype correlations are conducted. 


\subsection{Genetics of Usher syndrome}

As well as clinically, USH is genetically heterogeneous, since there are currently 10 genes responsible for the disease and several more associated (Table 2). USH1 is caused by mutations in either MYOTA, USH1C, CDH23, PCDH15, USH1G or CIB2. On their part, USH2A, $A D G R V 1$ and $W H R N$ are the three genes usually responsible for USH2, whereas CLRN1 is the single gene linked to the USH3 cases to date.

In the recent years, other genes have been proposed to be causative of the disorder, namely ABHD12, ARSG, CEP250, CEP78, ESPN and HARS (Eisenberger et al. 2012, Puffenberger et al. 2012, Khateb et al. 2014, 2018, Fu et al. 2017, Ahmed et al. 2018). However, the association of these genes to USH is controversial, given the few existing reports and that the symptoms do not entirely fit with the clinical picture of the syndrome. Therefore, it might be more prudent to consider them simply as USH-like. In addition, the PDZD7 gene has been proposed as a disease modifier when USH2A is involved, and a contributor to digenic inheritance together with ADGRV1 (Ebermann et al. 2010).

Table 2: Clinical and genetic subtypes of Usher syndrome

\begin{tabular}{|c|c|c|c|c|c|c|}
\hline Type & Hearing loss & RP onset & $\begin{array}{l}\text { Vestibular } \\
\text { alteration }\end{array}$ & locus & $\begin{array}{c}\text { Genes } \\
\text { (protein) }\end{array}$ & $\begin{array}{l}\text { Genomic coordinates } \\
\text { (GRCh38) }\end{array}$ \\
\hline \multirow{6}{*}{ USH1 } & \multirow{6}{*}{$\begin{array}{c}\text { Stable } \\
\text { Prelingual } \\
\text { Severe-profound }\end{array}$} & \multirow{6}{*}{$\begin{array}{c}\text { First } \\
\text { life decade }\end{array}$} & \multirow{6}{*}{ Yes } & USH1B & $\begin{array}{c}\text { MYO7A } \\
\text { (myosin VIla) }\end{array}$ & 11:77128246-77215241 \\
\hline & & & & USH1C & $\begin{array}{c}\text { USH1C } \\
\text { (harmonin) }\end{array}$ & 11:17493895-17544416 \\
\hline & & & & USH1D & $\begin{array}{c}\mathrm{CDH} 23 \\
\text { (cadherin 23) }\end{array}$ & 10:71396934-71815947 \\
\hline & & & & USH1F & $\begin{array}{c}\text { PCDH15 } \\
\text { (protocadherin 15) }\end{array}$ & 10:53802771-55627942 \\
\hline & & & & USH1G & $\begin{array}{l}\text { USHIG } \\
\text { (SANS) }\end{array}$ & 17: 74916083-74923256 \\
\hline & & & & USH1J & $\begin{array}{l}C / B 2 \\
(C I B 2)\end{array}$ & 15:78104606-78131544 \\
\hline \multirow{3}{*}{ USH2 } & \multirow{3}{*}{$\begin{array}{c}\text { Stable } \\
\text { Prelingual } \\
\text { Moderate-severe }\end{array}$} & \multirow{3}{*}{$\begin{array}{c}\text { Second } \\
\text { life decade }\end{array}$} & \multirow{3}{*}{ No } & USH2A & $\begin{array}{l}\text { USH2A } \\
\text { (usherin) }\end{array}$ & 1:215622891-216423448 \\
\hline & & & & USH2C & $\begin{array}{l}\text { ADGRV1 } \\
\text { (adhesion G protein- } \\
\text { coupled receptor V1) }\end{array}$ & 5:90529344-91164437 \\
\hline & & & & USH2D & $\begin{array}{l}\text { WHRN } \\
\text { (whirlin) }\end{array}$ & 9:114402080-114505473 \\
\hline USH3 & $\begin{array}{l}\text { Progressive } \\
\text { Postlingual } \\
\text { Variable }\end{array}$ & Variable & Variable & USH3A & $\begin{array}{c}\text { CLRN1 } \\
\text { (clarin-1) }\end{array}$ & 3:150926163-150972999 \\
\hline
\end{tabular}




\subsubsection{Genes involved in Usher syndrome type 1}

$\underline{\text { MYOTA }}$

MYO7A was the first gene to be associated with Usher syndrome. The implication of this gene was initially reported in 1992, when a region labelled USH1B was uncovered in chromosome 11 by linkage analyses in several families with USH1 (Kimberling et al. 1992). A while after, the definite gene comprising an $87 \mathrm{~kb}$ genomic region and encoding for myosin Vlla was finally identified (Weil et al. 1995).

The gene consists of 49 exons and, even though other alternative splicing isoforms have been reported (Chen et al. 1996, Sahly et al. 1997), the main isoform consists of 2215 amino acids encoded by a $7.4 \mathrm{~kb}$ region that does not include the first and half of the second exon (Figure 5) (Kelley et al. 1997).

The protein belongs to the family of the so called unconventional myosins, motor proteins that interact with actin and enable the intracellular molecular transport. They are structurally characterized by an acting-binding motor head domain, a neck domain with the function to interact with other proteins, and a tail region serving as an anchor for other cellular proteins (Inoue and Ikebe 2003). The latter is the differential part among myosins, and myosin VIla has particularly short tail domain that binds to SANS (USH1G)and harmonin (USH1C) (Wu et al. 2011, Li et al. 2017).

Expression occurs mainly in the cochlear hair cells, the retinal photoreceptors and RPE cells (Gibbs et al. 2010), and its respective function supposedly consists in hair bundle integrity by affixing the tip links of the stereocilia (Boëda et al. 2002, Kros et al. 2002, Grati and Kachar 2011), opsin transport from the inner to the outer segments (Liu et al. 1999a, Wolfrum and Schmitt 2000), and melanosome motility and discs phagocytosis (El-Amraoui et al. 2002, Gibbs et al. 2003).

Pathogenic variants of MYOTA account for about $50 \%$ of the USH1 cases, thus, it is the most prevalent gene among this subtype (Jaijo et al. 2007) and also the second most frequent gene among all the USH cases (Jouret et al. 2019). However, depending on the type and position, mutations in MYOTA have also been reported to result in atypical USH, autosomal dominant HL or autosomal recessive HL (Liu et al. 1998, Riazuddin et al. 2008, Mathur and Yang 2019). 


\section{$\underline{\text { USH1C }}$}

Harmonin is the protein of 899 amino acids encoded by USH1C, whose locus was traced in 1992 (Smith et al. 1992), prior to the gene identification eight years later by two groups simultaneously (Bitner-Glindzicz et al. 2000, Verpy et al. 2000). Mutations in USH1C are mainly responsible for $\mathrm{USH} 1$, but the gene is also associated to nsHL (Jain et al. 1998). It is presumed that mutations in the constitutive exons result in USH1 and mutations in the alternatively spliced exons lead to non-syndromic deafness (Reiners et al. 2006). However, studies in the last years have identified putative pathogenic mutations in cases with mild or of later onset RP (Khateb et al. 2012, Baux et al. 2017), which suggests that mutations in nonconstitutive exons could actually be causative of atypical USH cases.

The gene, which spans $51 \mathrm{~kb}$ of genomic region, presents 28 coding exons of which eight are alternatively spliced (exons 15 and 22-28), giving rise to an assortment of scaffold proteins (Verpy et al. 2000), all of them bearing PDZ domains that are known to serve to the arrangement of protein complexes (Figure 5) (Sheng and Sala 2001). In the inner ear and photoreceptors, harmonin is important for the assembly of the USH proteins, as it interacts with all USH1 and USH2 proteins (Boëda et al. 2002, Reiners et al. 2005b).

\section{$\mathrm{CDH} 23$}

Mutations in cadherin 23 are associated with both USH1 and non-syndromic autosomal recessive deafness (Bolz et al. 2001, Bork et al. 2001), and are the second most common cause of the former subtype in most populations. It appears that most missense mutations are associated to the $\mathrm{nsHL}$, presumably since they are hypomorphic and preserve some residual function tolerable for the retinal function, whilst loss of function variants (and some missense exceptions) result in USH1 (Astuto et al. 2002, Baux et al. 2008, Becirovic et al. 2008). This pattern of allelic hierarchy is met to the point that deafness-causing alleles phenotypically predominate over USH alleles (Schultz et al. 2011).

The $C D H 23$ gene covers more than $300 \mathrm{~kb}$ of the genome and contains 69 exons, of which two are microexons of 6 and $3 \mathrm{bp}$. It produces several alternative transcripts, being isoform a the longest with 3354 amino acids in length. The resulting transmembrane protein (Figure 5) presents 27 extracellular $\mathrm{Ca2}^{+}$-binding domains for cell-cell adhesion, whereas isoform b has only 7 and isoform $c$ none. The isoforms with extracellular domains are postulated to constitute (together with $P C D H 15$ ) the tip link connecting the adjacent stereocilia of the hair cells in the organ of Corti (Jaiganesh et al. 2018), whereas in the photoreceptors they are expressed in the junction of the outer and inner segments and 
throughout the calyceal processes, with a predicted function of shaping the OS (Sahly et al. 2012, Schietroma et al. 2017). The cytoplasmatic isoform c could play a role in microtubule network regulation (Takahashi et al. 2016).

\section{$\underline{P C D H 15}$}

PCDH15 is the other USH gene coding for a protein of the cadherin superfamily (Ahmed et al. 2001, Alagramam et al. 2001). This gene is also associated with non-syndromic deafness (Ahmed et al. 2003). The gene was firstly thought to comprise 33 exons that underwent alternative splicing, but later studies have introduced 6 novel exons that compute for even more isoforms (Ahmed et al. 2006, 2008).

PCDH15 covers the vast genomic region of $980 \mathrm{~kb}$, yet the longest isoform has a sequence of 1955 amino acids (Figure 5), and this is due to the large introns that size up to $150 \mathrm{~kb}$. The wide variety of isoforms are presumed to have diverse functions, however, protocadherins are closely linked to cadherin 23 by forming heterodimers and, therefore, share the same localizations and main function (Kazmierczak et al. 2007, McGrath et al. 2017). In recent studies, it has been suggested that protocadherin 15 provides the elastic elements of the tip links for the mechanotransduction (Araya-Secchi et al. 2016, Powers et al. 2017, Bartsch et al. 2019), and to be critical for the development and maintenance of the calyceal processes and OS of the photoreceptors (Schietroma et al. 2017).

\section{USH1G}

USH1G was demonstrated to be causative of USH a year after its locus identification (Mustapha et al. 2002, Weil et al. 2003). The gene is widely accepted as causative of USH1, however, a study from few years ago suggested its possible implication in nsHL (Maria Oonk et al. 2015), and two other works held it responsible for atypical USH (Kalay et al. 2005, Bashir et al. 2010).

Spanning little more than $7 \mathrm{~kb}$, this is the smallest USH gene. USH1G has three exons and only the first two are coding, resulting in the scaffold protein SANS (Scaffold protein containing ankyrin repeats and SAM domain) of 461 amino acids (Figure 5) that appears to be involved in the molecule transport through the microtubules and tip link maintenance (Maerker et al. 2008, Caberlotto et al. 2011, Overlack et al. 2011, Bauß et al. 2014, Sorusch et al. 2014, 2017). 
$\underline{C I B 2}$

The CIB2 gene was the latest to be associated to Usher syndrome on the basis of a homozygous missense mutation found among affected members of a large consanguineous USH1 family (Riazuddin et al. 2012). Parallelly, and with later supporting studies, the gene was also related to nsHL (Jacoszek et al. 2017).

The gene, which presents six exons with three deriving isoforms, encodes for the calcium- and integrin-binding protein 2 (CIB2), which presents EF hand $\mathrm{Ca}^{2+}$-binding domains, as its very name indicates. No additional CIB2 mutations in USH patients have been reported since the original publication, despite the growing number of highthroughput sequencing assays of USH cases performed since then.

\subsubsection{Genes involved in Usher syndrome type 2}

USH2A

USH2A was the first gene described for type 2 of Usher syndrome, after its locus identification by Kimberling et a/ (Kimberling et al. 1990, 1995), and it is also responsible for nsRP (Rivolta et al. 2000, McGee et al. 2010, Lenassi et al. 2015). This is the most prevalent gene responsible for USH cases overall (Yang et al. 2012, Jouret et al. 2019), which is greatly attributed to the recurrence of a single specific mutation of European origin, the c.2299delG (Dreyer et al. 2001, Aller et al. 2010b).

USH $2 A$ contains 72 exons, of which the first one is non coding, spanning $800 \mathrm{~kb}$ of the genome, and alternative splicing yields two isoforms ( $a$ and $b$ ) of the usherin protein (van Wijk et al. 2004). The shortest transcript, isoform a, was the first to be reported and comprises only the first 21 exons that translate into a 1546 amino acid extracellular protein (Eudy et al. 1998, Weston et al. 2000). In contrast, the longer transcript (Figure 5) with the additional 51 exons results in a 5202 amino acid transmembrane protein (van Wijk et al. 2004). In addition, another protein version has been described with an alternative exon 71 that is restrictive to the inner ear, resulting in 24 additional amino acids that correspond to the cytoplasmic domain (Adato et al. 2005a).

The short extracellular usherin was postulated to play a role in the homeostasis and development of both the inner ear and retina, since its expression was localized to the basement membranes (Bhattacharya et al. 2002).

The longer transmembrane usherin isoform constitutes an element of the ankle links, which attach the neighbouring stereocilia near the nascent region, together with the 
ADGVR1 protein (Adato et al. 2005a, Michalski et al. 2007). In the photoreceptors, usherin was detected in the zone where the apical IS envelops the CC and has been proposed to be necessary for the protein trafficking to the OS, with an ultimate incidence in the long-term maintenance of these cells (Liu et al. 2007).

\section{ADGRV1}

This gene has undergone three renamings, as it was first labelled VLGR1, later GPR98 and recently has finally been established as ADGRV1. Its direct involvement in USH2 was not disclosed until 14 years after the first USH gene identification (Weston et al. 2004).

The gene is alternatively spliced producing three isoforms out of 90 exons, all of them included in the isoform b. ADGRVI holds the position of not only the largest USH coding sequence, with a transcript length of $19 \mathrm{~kb}$ encoding 6306 amino acids for this longest isoform (Figure 5), but also of the largest cell surface protein known to date (McMillan et al. 2002, Sun et al. 2013).

As mentioned above, this adhesion G-protein coupled receptor V1 may share most of the functions of usherin, since it colocalizes at the ankle links of the stereocilia and in the recesses between the IS and CC of the photoreceptors (Michalski et al. 2007, Maerker et al. 2008). It was proposed that the gene is required for the correct maturation and disposition of the stereocilia (Yagi et al. 2007).

\section{WHRN}

WHRN, previously known as DFNB31 for its broad association to the deafness locus, is another gene associated to both USH2 and nsHL (Mburu et al. 2003, Ebermann et al. 2007). The gene has two predicted promoters and undergoes alternative splicing, yielding several mRNA transcripts, but its 12 exons mostly give rise to two major isoforms of the protein, known as whirlin (Mathur and Yang 2019).

The longest isoform, which includes all exons and translates into 907 amino acids (Figure 5), differs from the shorter in the presence of two $\mathrm{N}$-terminal PDZ domains, since the latter isoform poses a trimmed version that comes up from just the translation of exons 613 (Mburu et al. 2003). It seems that there is a differential phenotypic outcome depending on the damaged domains. Mutations affecting the last PDZ domain (PDZ3) shared by the two isoforms seem to result in profound SNHL (Mburu et al. 2003, Tlili et al. 2005, Yang et al. 2013, Richard et al. 2019), whilst the ones compromising the rest of the exons might in turn produce USH2, involving a milder hearing impairment (Ebermann et al. 2007, Audo et al. 
2011, Besnard et al. 2012, Jiang et al. 2015). This is also supported in some way by the findings of a study with domain-specific deletions in mice by Ebrahim and colleagues, which shows that disruption of the last exons (and thus the shorter whirlin isoform) was more aggressive in regard to the auditory function (Ebrahim et al. 2016).

There are extensive studies on the isoforms and localization of whirlin, and even so not all the results are in compliance. The two isoforms are expressed in the inner ear, but only the longer one is present in the retina, hence mutations in the 5 ' region that disrupt the extra PDZ domains were thought to cause USH and all other to result in only the hearing impairment (Yang et al. 2010). The diverse studies report on different localizations depending on the isoform and subtype of hair cell. Overall findings demonstrate that whirlin seems to have a pleiotropic effect, since the distinct isoforms are differentially expressed in the photoreceptors, IHC, OHC, and even transitionally in brain during development (Mburu et al. 2003, van Wijk et al. 2006, Ebrahim et al. 2016). In the inner ear, whirlin is highly expressed in the stereocilia tips and is required for their elongation regulation (Holme et al. 2002, Delprat et al. 2005, Kikkawa et al. 2005, Manor et al. 2011), but also to function as the ankle-link support of the protein products of USH2A and ADGRV1 by connecting them through their cytoplasmic regions (Adato et al. 2005a, van Wijk et al. 2006, Michalski et al. 2007). The latest findings concerning the inner ear showed that the shorter isoform was expressed in the very tips of the hair cell bundles and its likely function is indeed stereocilia length regulation, whereas the longer isoform displayed a lower localization coincident with the lateral links and, therefore, operates as organizer of the bundles (Ebrahim et al. 2016).

In photoreceptors, whirlin appears to localize around the $\mathrm{CC}$ and the synaptic region (van Wijk et al. 2006, Kersten et al. 2010, Yang et al. 2010).

\subsubsection{Genes involved in Usher syndrome type 3}

\section{CLRN1}

CLRN1 is the only gene to date associated to USH3, which, as previously mentioned, even though it is the rarest subtype, it has a prevalence over $40 \%$ in the Finnish population and it was in this community where the gene locus was originally mapped (Sankila et al. 1995). The gene itself was identified in 2001 (Joensuu et al. 2001), which presents four exons and produces the protein clarin-1, a four-transmembrane-domain protein (Figure 5) (Adato et al. 2002). Years later the gene was rendered more complex than initially thought, as 11 splice variants were detected, which were hypothesized to justify the clinical variation (Västinsalo et al. 2011). 
Based on its expression sites and animal models, several theories about its function have been postulated (Ogun and Zallocchi 2014), but one of the most prevailing is that clarin-1 plays a role in the cochlear and photoreceptor synapses (Adato et al. 2002, Geng et al. 2009, Zallocchi et al. 2009, Ogun and Zallocchi 2014).

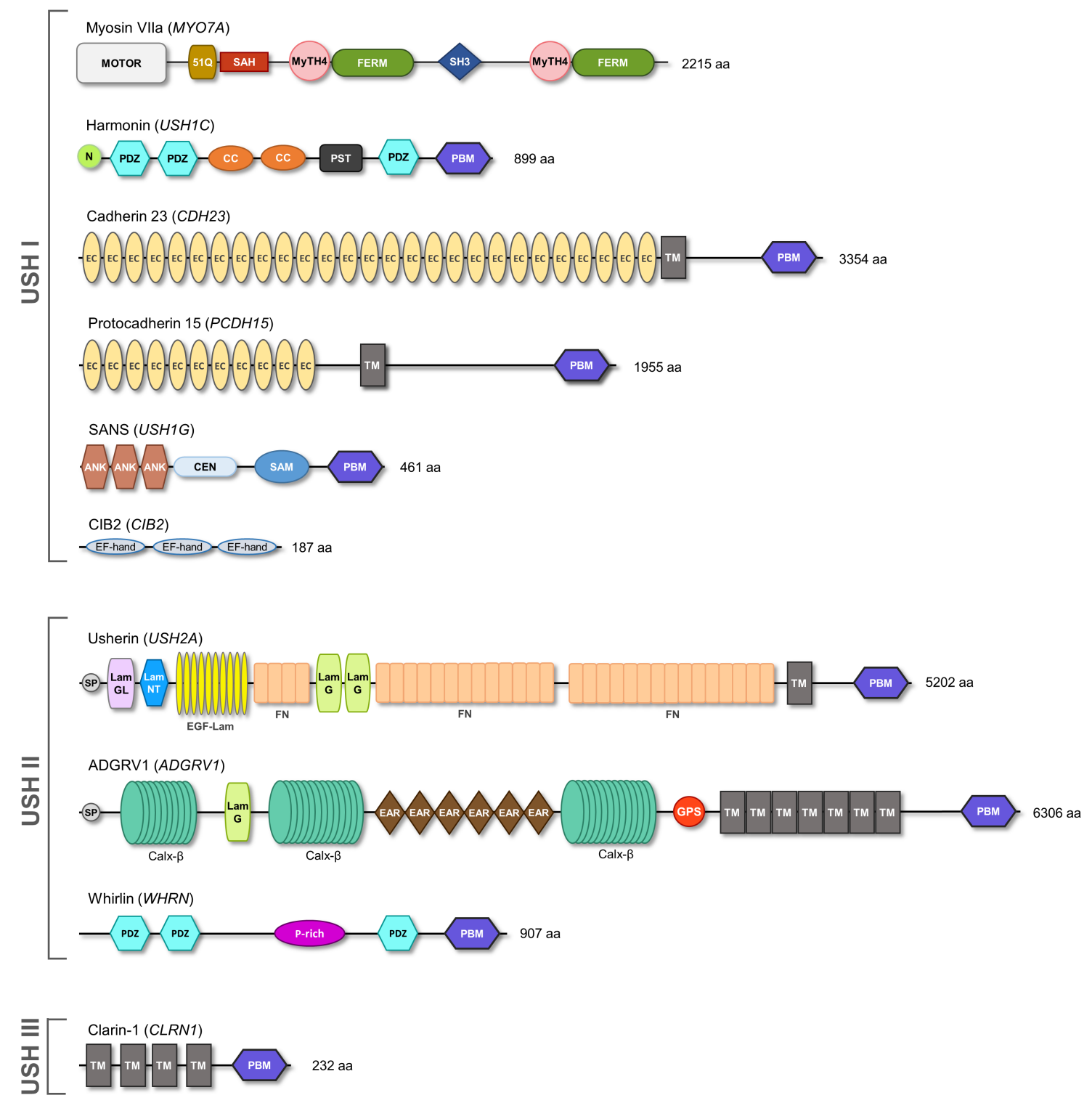

Figure 5. Schematic representation of the USH proteins as for to the longest or canonical isoforms of each protein. Abbreviations: aa, amino acid; 5IQ, Five IQ motifs; SAH, Single alfa-helix domain; MyTH4; Myosin Tail Homology 4 domain; FERM, FERM domain (F for 4.1 protein, E for ezrin, R for radixin and M for moesin); SH3; Src Homology 3 domain; $\mathrm{N}, \mathrm{NH}_{3}$ terminal domain; PDZ, PDZ-domain; CC, coiled-coil domain; PST, Proline/serine/threonine-rich domain; PBM, PDZ-binding domain; EC, Extracellular domain; TM, Transmembrane domain; ANK, Ankyrin repeat; CEN, Central domain; SAM, Sterile alpha motif; EF-hand, EF-hand domain (helix-loop-helix structural domain); SP, Signal peptide; LamGL, LamG-like jellyroll fold domain; LamNT, Laminin N-terminal domain; EGF-Lam, , laminin EGF-like domain; FN, Fibronectin domain; LamG, Laminin G domain; Calx- $\beta$, Calx- $\beta$ motif; EAR, (EAR/EPTP) epilepsyassociated repeats/epitemptin; GPS, GPCR proteolytic site; P-rich, Proline-rich domain. 


\subsubsection{The USH interactome}

The lot of the known USH proteins encompass scaffold, cell adhesion, transmembrane receptor and motor proteins, with specific variable functions. Still, the failure of any of them results in almost the same phenotype. This is explained because all of the USH proteins interact with at least another of the group, building thus a protein network defined as the USH interactome (Figure 6). These interactions have been confirmed through in vivo and in vitro assays. In addition, protein interaction screenings have also revealed the engagement of this network with other non-USH proteins, many of which are associated to other retinal diseases and syndromic ciliopathies (Sorusch et al. 2014).

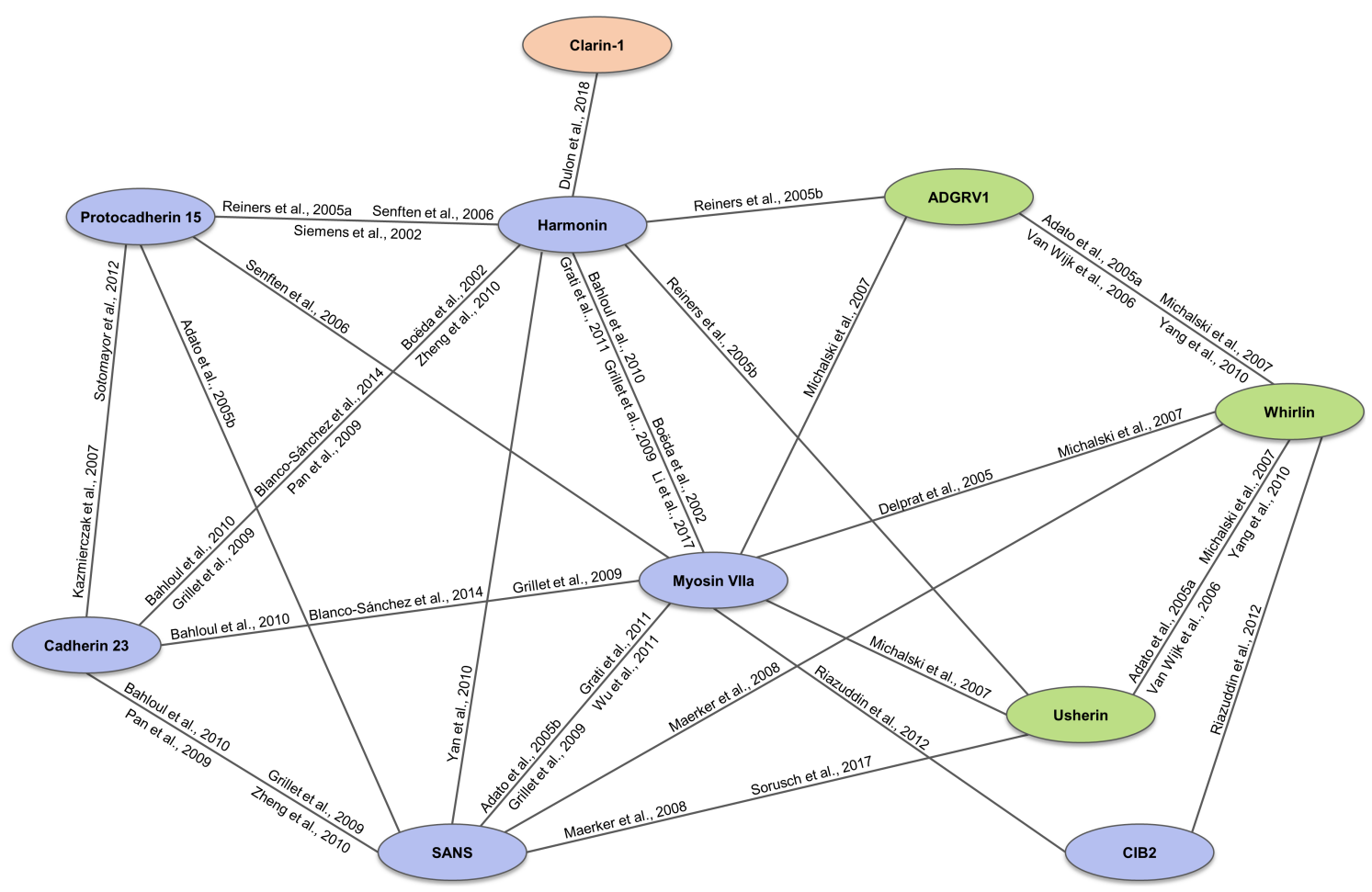

Figure 6. Representation of USH the interactome. The connecting lines stand for the detected interactions between the proteins USH1 (blue), USH2 (green) and USH3 (orange) proteins, according to the in vitro and in vivo studies to date (specified alongside the lines).

There is evidence that harmonin, whirlin and SANS stand as the scaffold kernel of the complex. For example, in the inner ear, the extracellular links between the stereocilia formed through cadherin 23 and protocadherin 15 are intracellularly anchored through these three scaffold proteins by tethering with the cytoskeleton or by the interaction with other USH proteins, such as myosin VIla (Figure 7). In the photoreceptors, this interactome prevails at the periciliary membrane complex level, where the CC, the segments junction and calyceal processes concur, and the synaptic region (Millán et al. 2011, Sorusch et al. 2014). 


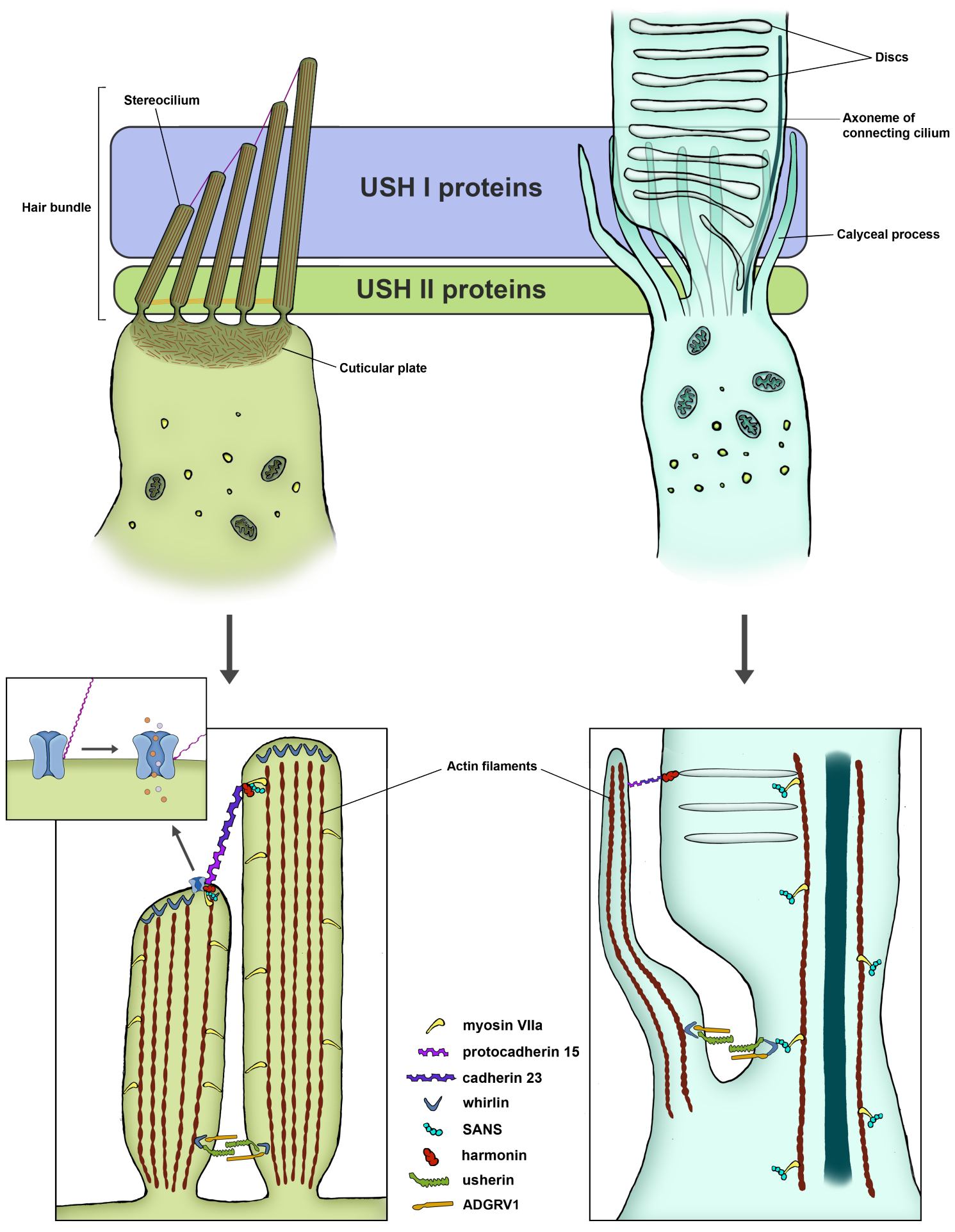

Figure 7. Localization of the USH proteins. Essentially, USH1 proteins can be found in the apical region of the hair bundle, including the tip links (violet lines), and at the OS and calyceal processes of the photoreceptors. USH2 proteins rather locate to the ankle links (orange lines) of the stereocilia and to the periciliary region of the photoreceptors. Zoom-ins below depict the estimated localization of most of the USH proteins based on the literature. An additional closeup of the stereocilia heads represents the transition of the mechanoelectrical transduction (MET) channels from closed to open state leading to the inlet of $\mathrm{Ca}^{2+}$ and $\mathrm{K}^{+}$ions, as a result of the lateral deflection of the stereocilia by the movement of the tectorial membrane. 


\subsection{Molecular diagnosis of Usher syndrome}

The identification of the genetic mutations underlying USH is of great relevance for several reasons. In the first place, rare syndromic diseases sometimes overlap or mirror symptoms, making the diagnosis and comprehension of the disease harder. The determination of the genetic cause confirms the clinical diagnosis and enables a more accurate prognosis for the patient, something that becomes even more precise with every new molecular finding that updates the genotype-phenotype correlations. Moreover, it provides the possibility of genetic counselling for the prevention of disease transmission to the offspring. Lastly, it is essential for the enrollment in therapy trials or for the reception of eventual future treatments, most of which are gene or mutation dependent, as it will be explained in the next section (3.4).

\subsubsection{Genetic etiology determination}

The current principal method for the molecular diagnosis of USH and most genetically heterogeneous diseases is high-throughput sequencing (HTS), previously known as next generation sequencing (NGS). HTS has replaced other for-this-purpose now obsolete technologies such as positional cloning, SNP-RFLP, SNP arrays or Sanger sequencing, though the latter is still essential for mutation validations. This technology consists in the parallel sequencing of multiple genomic regions, and it is scalable, meaning that the technique allows to sequence from targeted genomic loci (such as the coding regions of the known causative genes), to more extensive regions like the complete exome or even the whole genome. The lot of applications of this method are customized targeted exome sequencing (TES), predesigned clinical exome sequencing (CES), whole exome sequencing (WES), whole genome sequencing (WGS), expression analysis (RNA sequencing), and methylation profiling (Epigenetic sequencing).

The outcomes of these assays yield massive variant results that need further computational processing and data curation in order to be interpreted. Firstly, each sequencing read needs to be aligned with the reference genome to check for possible variants. These must be subsequently evaluated to differentiate the polymorphisms from the potentially pathogenic alterations. There are several projects with the sole purpose of developing variant databases by gathering as many individual genome or exome sequencings as possible, among which are the International Genome Sample Resource (1000 Genomes project), the Genome Aggregation Database (gnomAD) or the Exome Aggregation Consortium (ExAC). By publicly providing allele frequencies, and recently also 
some gross phenotype correlations, it is easier to conclude mutation pathogenicity based on their prevalence. This is very useful for genome-wide association studies (GWAS) and for rare diseases diagnoses, the latter greatly relying on a minor allele frequency (MAF) cutoff.

There are other human variant resources that collect all the published phenotypegenotype correlations and other disease-private databases that also play an important role in the identification of pathogenic variants, including but not limited to the Leiden Open Variation Database (LOVD), ClinVar, Online Mendelian Inheritance in Man (OMIM), or the Human Gene Mutation Database (HGMD) (Stenson et al. 2003, McKusick 2007, Fokkema et al. 2011, Landrum et al. 2018).

Furthermore, other bioinformatic tools are developed to filter, prioritize and predict the tolerance of the variants with the aim of identifying the putative pathogenic mutation responsible for a disease (Niroula and Vihinen 2016).

\subsubsection{HTS and its application to USH diagnostics}

Even though they share the same end, there are several sequencing platforms, each of which present different advantages and weaknesses, such as throughput, read length, library preparation, run time, expense, etc. These different platforms have been arranged in three distinct categories. First-generation sequencing platforms comprise the initial entrepreneur systems such as Sanger sequencing. Later and current massive parallel sequencing methods, including Roche 454, SOLiD, Illumina, or Ion Torrent, are regarded as the second generation-sequencing platforms. Finally, the new platforms that enable singlemolecule long-read sequencing, and some also a real-time survey, fall into the category of the third generation sequencing technologies, yet they are still being polished and have not been used in many assays.

Since the first HTS technique release in 2005, there have been several approaches for molecular diagnosis of USH, including TS, WES, and WGS, using several cohorts and most of the second-generation platforms. Given the genetic heterogeneity and the large size of the genes involved in the disease, it is not surprising that the genetic diagnosis of USH nowadays relies on HTS methods (as displayed in Table 3), mainly with customized targeted sequencings. However, a number of patients remain unresolved because of lacking pathogenic mutations in the expected USH genes. 
Table 3: Summary collecting the references of most of the molecular diagnosis studies of USH based on HTS strategies, including those composing the present dissertation

\begin{tabular}{|c|c|c|c|}
\hline & TES/CES & WES & WGS \\
\hline Illumina & $\begin{array}{l}\text { Licastro et al. 2012, } \\
\text { Wei et al. 2012, } \\
\text { Huang et al. 2013, } \\
\text { Aparisi et al. 2014, } \\
\text { Bujakowska et al. 2014, } \\
\text { Chen et al. 2014, } \\
\text { Eisenberger et al. 2014, } \\
\text { Krawitz et al. 2014, } \\
\text { Oishi et al. 2014, } \\
\text { Jiang et al. 2015, } \\
\text { Qu et al. 2015, } \\
\text { Shu et al. 2015, } \\
\text { Zhai et al. 2015, } \\
\text { Bonnet et al. 2016, } \\
\text { Dad et al. 2016, } \\
\text { Yang et al. 2016, } \\
\text { Cheng et al. 2017, } \\
\text { Eandi et al. 2017, } \\
\text { Khan et al. 2017, } \\
\text { Neuhaus et al. 2017, } \\
\text { Abdelkader et al. 2018, } \\
\text { Kooshavar et al. 2018, } \\
\text { Ramzan et al. 2018, } \\
\text { Sun et al. 2018, } \\
\text { Wei et al. 2018, } \\
\text { Okano et al. 2019. }\end{array}$ & $\begin{array}{l}\text { Reddy et al. 2014, } \\
\text { DeLuca et al. 2015, } \\
\text { Koparir et al. 2015, } \\
\text { Zheng et al. 2015, } \\
\text { Khan et al. 2017, } \\
\text { Xia et al. 2017, } \\
\text { Jia et al. 2018, } \\
\text { Zhang et al. 2018, } \\
\text { Fuster-García et al. 2019, } \\
\text { Ng et al. } 2019 .\end{array}$ & $\begin{array}{l}\text { Fu et al. 2017, } \\
\text { Khan et al. } 2017 .\end{array}$ \\
\hline Ion Torrent & $\begin{array}{l}\text { Yoshimura et al. 2014, } \\
\text { Lenarduzzi et al. } 2015, \\
\text { Fuster-García et al. } 2018, \\
\text { Ivanova et al. } 2018, \\
\text { Santana et al. } 2019 .\end{array}$ & & \\
\hline $\begin{array}{c}454 \\
\text { (Roche) }\end{array}$ & $\begin{array}{l}\text { Licastro et al. 2012, } \\
\text { Besnard et al. 2014, } \\
\text { Liquori et al. } 2016 .\end{array}$ & & \\
\hline SOLiD & & Licastro et al. 2012 & \\
\hline
\end{tabular}




\subsection{Therapeutic approaches for Usher syndrome}

USH is a very disabling disease by having the two most important senses necessary for the interaction with the surroundings, vision and hearing, hampered. Unfortunately, there is still no cure for the disorder and the available solutions are very limited. The most promising treatments are still on research or in clinical trials at most. They can be divided in two groups depending on if the curing aim is set for a specific genotypic target or if it is mutationindependent.

In view that the already existing hearing aids or cochlear implants for the auditory impairment present a good-enough alleviating solution, research on therapies targeting the retinal degeneration is more abundant (Figure 8).

\subsubsection{Pharmacological approaches}

Retinal degeneration due to RP presents a staged course where many factors play a role accelerating or leading to the ultimate photoreceptor death, such as apoptosis signaling, oxidative stress and inflammation. There are many drug-based treatments being assayed that target all these peripheral effects, with the intention of halting or delaying the disease evolution regardless of the genetic variability.

Amongst the many molecules being researched, there are some neuroprotective compounds like the ciliary neurotrophic factor (CNTF), the rod-derived cone viability factor (RdCVF), nerve growth factor (NGF) (Guadagni et al. 2015), or N-Acetylcysteine Amide (NACA) (Schimel et al. 2011). There are also promising anti-apoptotic substances to slow down the retinal degeneration, like minocycline, myoricin, dexamethasone, anti-TNF $\alpha$ drugs or the HIF-1 $\alpha$-stabilizer DMOG (Guadagni et al. 2015, Martínez-Fernández de la Cámara et al. 2015, Dias et al. 2018, Olivares-González et al. 2018, Chemi et al. 2019).

Similarly, it is believed that the loss of sensory hair cells in the inner ear results in further neuronal damage due to neurotrophin privation. This leads to an oxidative state and an ultimate $\mathrm{Ca}^{2+}$ homeostasis disturbance, which could be partially buffered with the administration of calcium blockers or neurotrophic factors (Mittal et al. 2017). However, this practice has not been specifically explored in USH patients.

Beyond these general delaying pharmaceutical compounds, there are others with a more specific impact, yet not so genotype-independent, such as the drugs for translational readthrough of premature termination codons (PTCs). The PTC124 molecule, also known as Ataluren or Translarna (PTC Therapeutics), is the most potent readthrough molecule and 
does not entail the typical renal or ototoxic side effects of the other aminoglycoside family compounds with similar function (Welch et al. 2007). The molecule interacts with the ribosome prompting it to overlook the nonsense stop signal and, therefore, allowing the translation of the full-length protein. PTC124 has been mainly exploited for cystic fibrosis or Duchenne muscular dystrophy and, regarding USH, this nonsense inhibitor has still only been contemplated for the p.R31X mutation in USH1C (Goldmann et al. 2011, 2012). However, being a drug targeting nonsense mutations, it may be used for any premature stop mutations in any of the USH genes. Still, the mechanism involves the insertion of another random amino acid and not precisely the wild type variant, since it depends on the type of stop-codon, the whole transcript composition and the near-cognate tRNAs available (Dabrowski et al. 2018). Thus, this pharmacogenomics approach might stand as a potent treatment, but sometimes it may rather mitigate than cure the disorder by yielding other analogously-functional USH proteins instead of the truncated one.

Another example of a mutation-dependent potential therapeutic molecule is BF844 that, according to one preclinical publication, reduces hearing loss if the causative mutation is p.N48K in the CLRN1 gene. The mutation is thought to impact on the protein folding and stability, and the prospective therapeutic molecule supposedly increases this stability, yet further evidence and research shall be carried out before a clinical trial is launched (Alagramam et al. 2016).

\subsubsection{Gene therapies}

Gene therapy comprises those experimental techniques that use and/or target genetic components to correct the pathogenic effect of mutations causing a disease at the nucleic acids level, and it is therefore considered as precision medicine.

The retina represents an ideal tissue for this type of approaches because of three main reasons: it is accessible with the modern vitreoretinal surgery tools, it enables noninvasive monitoring and, foremost, the eye is an immune-privileged organ due to its relative systemic isolation status through a local blood barrier, which prevents both the trespass of immunological cells and the scattering of the potential treatments through the rest of the organism (Benhar et al. 2012, Sengillo et al. 2016).

The inner ear does not share all these ocular benefits. However, it still enables a relatively easy access to the hair cells, since the cochlea is composed of liquid-filled sealed chambers that allow dissemination of the delivered molecules and, at the same time, this 
somewhat sealed environment also reduces systemic dispersal of the treatment (Emptoz et al. 2017, Kanzaki 2018).

Among the different types available of gene therapy, gene augmentation, antisense oligonucleotides and gene editing are the most prevailing strategies as potential treatments for USH.

\subsubsection{Gene augmentation therapies}

Gene therapy via gene supplementation is a trendy technique in the last years with the potential for treating many diseases, and many approaches have already gone on clinical trials. The method is based on the organ-specific delivery of a wild type copy of a particular gene or its coding sequence into the cells carrying the genetic aberration, usually with the means of viral vehicles.

This strategy, though, is genotype-dependent, since the provision must be of the specific gene responsible for the phenotype. In addition, it is not suitable for all cases, essentially because of the difficulty at targeting certain tissues, or due to the presence of several isoforms or the large size of the transcripts making their packaging into the viral vector almost impossible, like the USH genes USH2A or ADGRV1.

Nevertheless, there are some assays involving the smaller USH genes in murine models. The whirlin cDNA replacement was first tested in the retina proving its safe and efficient expression in the photoreceptors comparable to the endogenous version, by using an adeno-associated virus (AAV) and the human rhodopsin kinase promoter, specifically targeting rod and cones (Khani et al. 2007, Zou et al. 2011). Later on, supplementation of the gene was also performed focusing on the inner ear with AAV8, with final successful restoration of hearing and balance functions (Isgrig et al. 2017). Other researchers have also recently claimed to recover auditory and balance function in mice models defective for USHIG and USH1C, by delivering wild type coding sequences of SANS and harmonin, respectively (Emptoz et al. 2017, Pan et al. 2017), and similar augmentation approaches have been done for CLRN1 (Geng et al. 2017, Dulon et al. 2018, Gopal et al. 2019, György et al. 2019).

Despite its big size, MYO7A was paradoxically the very first gene to be tried in USH for gene therapy, up to the point that a phase I/II clinical trial is currently undergoing since 2012 (SAR 421869/UshStat) (Hashimoto et al. 2007, Zallocchi et al. 2014). Though the initial studies used lentiviral vehicles to pack the whole cDNA sequence based on their greater cargo capacity, the latter works and consequent clinical trial have applied a 
different strategy to overcome the large size of the gene using dual AAV vectors. In this curious approach, researchers have opted to split the coding sequence in two for their simultaneous delivery in separate AAV vectors, resulting in the intracellular merging of the two fragments through homologous recombination, which finally leads to a fulllength functional MYOTA mRNA and protein (Lopes and Williams 2015).

Other non-USH genes that cause RP are also already being assessed in clinical trials or even commercialized, such as RPE65 for Leber Congenital Amaurosis, which is the first FDA-approved gene therapy for a retinal disease (Luxturna). This has set a precedent and, therefore, the development of new gene supplementation therapies for the USH genes will probably progress smoothly once fully tested at pre-clinical stages.

\subsubsection{Antisense Oligonucleotides}

There are many techniques that can be regarded as gene therapies, and the use of antisense oligonucleotides (AONs) is another system included in the field, whose mechanism of action concerns the RNA processing. AONs are short single stranded oligodeoxynucleotides that bear other chemical modifications towards its increased stability and cellular uptake, which are designed to bind to a target pre-mRNA by complementary base pairing (Goyal and Narayanaswami 2018). The result of this attachment causes exon inclusion or exclusion (by a steric obstruction of the splicing factors), or the degradation of the transcript (by recruiting the RNase $\mathrm{H}$ or preventing ribosomal initiation). These possible fates depend again on the chemical modifications of the molecule (Collin and Garanto 2017, Rinaldi and Wood 2018).

There are already some AON-based therapies that have been approved for their clinical use, for example for the treatment of cytomegalovirus retinitis (fomivirsen), spinal muscular atrophy (nusinersen), Duchene muscular dystrophy (eteplirsen), and a number of research studies focused on the USH1C and USH2A genes have also been conducted (Lentz et al. 2013, Slijkerman et al. 2016, Stein and Castanotto 2017). In particular, a clinical trial that is designed to treat mutations located in exon 13 of the USH2A gene, mainly the c.2299delG and c.2276G > T prevalent variants, has recently started (STELLARNCT03780257). The AON, named QR-421a (ProQR company), aims to exclude the complete compromised exon, which produces a shortened yet functional version of usherin. Furthermore, another molecule targeting a specific and quite recurrent mutation in the same gene is also on the way of being approved for its testing in humans. The deep-intronic c.7595-2144A>G mutation (accounting for about 4\% of the USH2A 
pathogenic variants in France and Spain) results in the inclusion of a pseudo-exon in the transcript in between of exons 40 and 41 , but the AON-based QR-411 drug binds to the region, avoiding its recognition by the splicing machinery and producing the skipping of this unnatural exon (Slijkerman et al. 2016).

The effectivity versus lastingness of these treatments must be still assessed to deem its worthiness, yet it seems to be a promising tool to tackle many USH mutations.

\subsubsection{Gene editing}

Gene editing (or genomic editing) has been the cutting-edge area of the last years, especially since the discovery of the Clustered Regularly Interspaced Short Palindromic Repeats (CRISPR) system. Rather than introducing an exogenous auxiliary nucleic acid fragment into the cell as in the gene augmentation strategies, in this field the endogenous DNA itself is modified through complexes that recognize the specific targeted sequences, allowing a directed edition.

There have been several nucleases through the history for this purpose, but the most significant ones are the zinc finger nucleases (ZFNs), the transcription activator-like effector nucleases (TALENs), and the CRISPR associated (Cas) proteins with Cas9 as the principal enzyme of this family. The CRISPR system has ousted the others given its easy design and versatility (Fernández et al. 2017). Despite its differences, all of them share the same mechanism: the predesigned cleavage of the double stranded DNA at precise loci in order to introduce specific changes in the sequence by profiting from the own repair machinery of the cell (Fernández et al. 2017).

There are few gene editing assays concerning USH, yet there have been advances for other genes responsible for other syndromic and also non-syndromic retinal diseases, to the point that the first-ever in vivo clinical trial using the system in humans is for CEP290 (EDIT-101), a gene responsible for Leber Congenital Amaurosis (Sheridan 2018). Braking down the barriers to genome manipulation as treatment for diseases, these advances inspire hope for an increase in the research of the USH field regarding the correction of causative mutations, blazing the trail towards real personalized medicine.

\subsubsection{Cell therapy}

Another field that is being researched towards sight and hearing restoration is cell transplantation to replace those lost in both the inner ear and retina. 
Regarding the inner ear, there have been many studies in the last two decades trying to use either embryonic stem cells (ESCS), induced pluripotent stem cells (iPSCs) or otic precursors for the restoration of the degenerated hair cells (Lee and Park 2018, Ma et al. 2019). The majority of the transplantation approaches are conducted with spiral ganglion cells, probably because the accessibility to the organ of Corti, and consequently the homing of the new hair cells for restocking, is very restricted, not to mention the hostile environment that would also contribute to the reduced survival of the donor cells (Hu and Ulfendahl 2013, Géléoc and Holt 2014, Mittal et al. 2017, Lee and Park 2018, Ma et al. 2019). Successful integration of the transplanted cell within the tissue and synaptogenesis preservation is still an unsolved issue.

With respect to the retina, many studies have been performed in the last years with the focus on ascertaining if the mere replacement of the dead retinal cells could restore visual function. Indeed, there have been preclinical studies in RP models claiming a successful partial vision restoration after subretinal cell transplantation (MacLaren et al. 2006, Lamba et al. 2009, Pearson et al. 2012, Barber et al. 2013, Singh et al. 2013, Santos-Ferreira et al. 2015, Barnea-Cramer et al. 2016, Collin et al. 2019). Polemic issues have been raised ever since, as whether the successful outcome was explained by either the effective integration of the donor cells, including the neuronal circuitry rebuilding, or rather by their fusion with the host residual cells and incurring in cytoplasmic material transfer (Gasparini et al. 2019). Apparently, according to a recent study, both events take place and account for the visual rescue (Waldron et al. 2018). However, the lastingness of the proceeding and if the grafted cells are dependent on still-persistent original photoreceptors, and if they are able to establish functional synaptic connections with the second order neurons and the RPE layer by themselves in already photoreceptor-deserted retinas, still remain unclear.

There are two main sources for the transplantation, either with retinal sheets upon the remaining neural tissue or the infusion of dissociated cells in the area, which can proceed from several sources, namely from stem cells or iPSCs-derived retinal progenitors, photoreceptor precursors or the more complex organoids (Gasparini et al. 2019).

There are some ongoing clinical trials of cell transplantation in RP patients, mostly with autologous bone-marrow stem cells (NCT01068561, NCT01560715, NCT02280135, NCT01736059, NCT02709876) or retinal progenitors (NCT02320812, NCT03073733, NCT02464436, NCT00447993, NCT00447980, NCT00063765, NCT00458575), yet the effectiveness remains unproven (Dias et al. 2018). 


\subsubsection{Prosthetic systems}

There are some devices that help to alleviate the symptoms of Usher syndrome. Hearing aids help in the $\mathrm{HL}$ in the way that they amplify the sound, but for the very same reason it is sometimes ineffective in noisy atmospheres. If there is profound deafness, cochlear implants are an option in many cases and they work replacing the inner ear function by directly stimulating the auditory nerve, but it offers better results and adaptive responses if the intervention is done in early stages of life (Loundon et al. 2003, Pennings et al. 2006, Hoshino et al. 2017).

Regarding vision assistance, there is a prosthetic system for the most severe cases with none or almost no light perception. The Argus II device provides a sort of artificial vision by sidestepping the photoreceptors and supplying the electric stimuli directly to the residual retina (Rachitskaya and Yuan 2016). This retinal prosthesis is composed of a set of glasses, an external video processing unit, and an on-globe surface implant coil that connects through cables to the last component, an electrode in the retina. However, it is very rudimentary, given that the patients only aspire to visualize brightness and shapes, and cumbersome, since the system comprises the mentioned lot of components, which in turn can also produce some serious adverse effects (e.g. conjunctival erosion, hypotony, uveitis, etc) (da Cruz et al. 2016, Rachitskaya and Yuan 2016).

Apart from the Argus II system, there are other similar systems like the other epiretinal prosthesis IRIS II or EPI-RET3, the subretinal focused devices such as Alpha IMS/AMS and PRIMA, or even some suprachoroidal prostheses approaches (Bloch et al. 2019). However, these somewhat bionic eyes are quite invasive and only aim to provide the patients with partial self-sufficiency by enabling some spatial and object recognition, but no accurate vision.

\subsubsection{Optogenetic strategies}

There is another field that is being researched for restoring vision. Optogenetics is a technique combining optics and genetics with the purpose of being able to modulate neural cells through photostimulation (Mahmoudi et al. 2017). In relation to RP, this method aims to turn the remaining cells from degenerated retinas, like the surviving cone bodies or bipolar cells, into counterfeit photoreceptors by ectopically expressing opsins such as channelrhodopsin 2 (ChR2), halorhodopsin (NpHR), melanopsin, or human rhodopsin (Sahel et al. 2015, Dalkara et al. 2016). This approach might delay the disease through the resensitization of the dying photoreceptors or the restoration of some vision-resembling 
function by providing rod-like features to other neural cell types. Most studies are still in pre-clinical stages, except for two phase I/II trials by RetroSense Therapeutics (RST-001) and GenSight Biologics (GS030-DP) (Simunovic et al. 2019).

A suchlike stratagem still under research is the use of chemical photoswitches, viewed as synthetic optogenetics. These are photochromic compounds that undergo chemical reactions after a particular wavelength absorption that transiently confer light sensitivity to non-photoreceptor cells, usually retinal ganglion cells, by interacting with voltage-gated ion-channels (Tochitsky et al. 2018). Several studies prove the recovery of light-triggered signal transduction in mouse models using azobenzenes (Tochitsky et al. 2016). Nevertheless, the low durability of the photosensitization and potential toxicity must still be addressed (Marc et al. 2014, Berlin and Isacoff 2017).

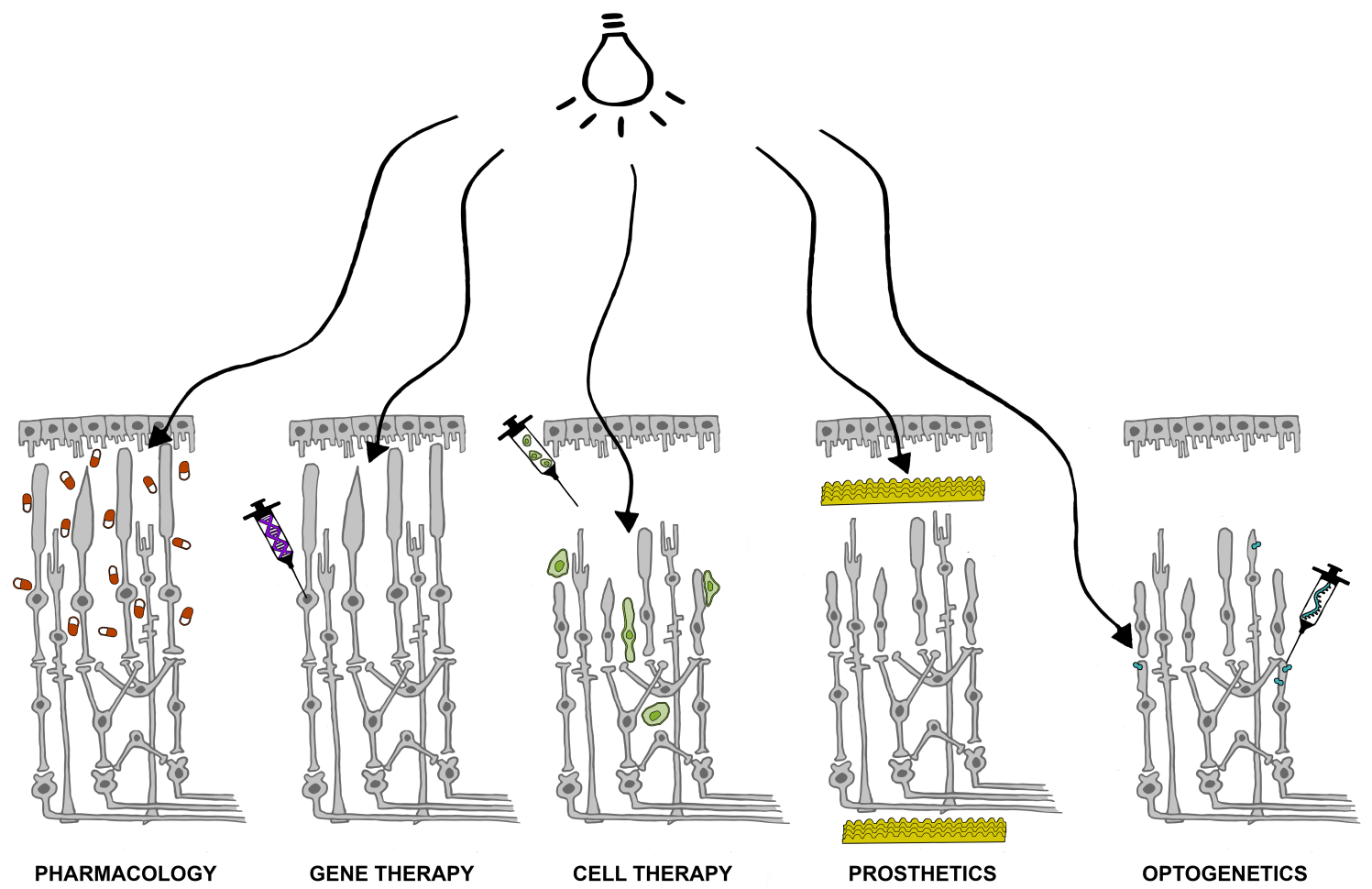

Figure 8. Schematic recapitulation of the therapeutic approaches for RP. Pharmacological options aim to buffer side-effects due to photoreceptor loss and delay further cell decay. Gene therapy directly addresses the underlying genetic alteration by either correcting it or supplying a functional gene copy. Cell therapies provide new cells to the retina, which engage with the remaining as supporting cells, or differentiate and replace the degenerated ones. Prosthetic devices, either subretinal (upper microelectrode array) or epiretinal (bottom microelectrode array), act as a surrogate of the retina and convey the light-intake signal directly to the nerve. Optogenetics attempts to confer photoreceptor-like light sensitivity to other retinal cells. 


THESIS OBJECTIVES 



\section{THESIS OBJECTIVES}

1. Developing a therapeutic approach based on genome editing with the CRISPR/Cas9 system to repair the most prevalent USH mutation, the c.2299delG in USH2A, in patientderived cells to potentially lay the ground for a later genotype-specific treatment.

2. Assessing the mutational background of USH patients among the Spanish population by means of targeted HTS of an unstudied cohort. This will increase the knowledge of the genotype-phenotype correlations, reveal novel pathogenic variants, and possibly provide further insights into some of the undercharacterized disease-associated genes.

3. Broadening the genetic survey of molecularly unresolved USH cases, previously screened for the customary regions, through the study of their whole exome. The aim is set to either uncover new candidate genes responsible for the disorder, or to disclose the pathogenic variants in other already characterized non-USH genes somehow giving rise to the phenotype. 



\section{CHAPTER I}

\section{USH2A Gene Editing Using the CRISPR System}

Carla Fuster-García ${ }^{1}$, Gema García-García ${ }^{1,2}$, Elisa González-Romero ${ }^{1}$, Teresa Jaijo ${ }^{1,2,3}$, María D. Sequedo ${ }^{1,2}$, Carmen Ayuso ${ }^{2,4}$, Rafael P. Vázquez-Manrique ${ }^{1,2}$, José M. Millán ${ }^{1,2}$, and Elena Aller ${ }^{1,2,3}$.

\footnotetext{
${ }^{1}$ Grupo de Investigación en Biomedicina Molecular, Celular y Genómica, Instituto de Investigación Sanitaria La Fe (IIS La Fe), Valencia, Spain; ${ }^{2}$ CIBER de Enfermedades Raras (CIBERER), Madrid, Spain; ${ }^{3}$ Unidad de Genética y Diagnóstico Prenatal, Hospital Universitario y Politécnico La Fe, Valencia, Spain; ${ }^{5}$ Servicio de Genética, Fundación Jiménez Díaz, University Hospital, Instituto de Investigación Sanitaria Fundación Jiménez Díaz IIS-FJD, UAM, Madrid, Spain.
}

Molecular Therapy - Nucleic Acids, Volume 8, p529-541 (2017)

doi: 10.1016/j.omtn.2017.08.003

(Adapted to meet the format of the present dissertation) 


\section{Abstract}

Usher syndrome (USH) is a rare autosomal recessive disease and the most common inherited form of combined visual and hearing impairment. Up to 13 genes are associated with this disorder, with USH2A being the most prevalent, due partially to the recurrence rate of the c.2299delG mutation. Excluding hearing aids or cochlear implants for hearing impairment, there are no medical solutions available to treat USH patients. The repair of specific mutations by gene editing is, therefore, an interesting strategy that can be explored using the CRISPR/Cas9 system. In this study, this method of gene editing is used to target the c.2299delG mutation on fibroblasts from an USH patient carrying the mutation in homozygosis. Successful in vitro mutation repair was demonstrated using locus-specific RNA-Cas9 ribonucleoproteins with subsequent homologous recombination repair induced by an engineered template supply. Effects on predicted off-target sites in the CRISPRtreated cells were discarded after a targeted deep-sequencing screen. The proven effectiveness and specificity of these correction tools, applied to the c.2299delG pathogenic variant of USH2A, indicates that the CRISPR system should be considered to further explore a potential treatment of USH. 


\section{Introduction}

Usher syndrome (USH) is an autosomal recessive disease involving sensorineural hearing loss, retinitis pigmentosa (RP), and, in some cases, vestibular dysfunction. It is a rare disorder with a prevalence ranging from 3 to 6.2 per 100,000 and it is the most common genetic cause combining hearing and vision loss (Millán et al. 2011), for which no clinical treatment is presently available. Three clinical forms of the disease can be distinguished according to severity and progression: USH type I (USH1), type II (USH2), and type III (USH3), with USH type II (USH2) being the most frequent clinical form. This type is defined by congenital moderate-severe hearing loss and RP of post-pubertal onset (Millán et al. 2011).

USH is clinically and genetically heterogeneous, since it is associated to date with 13 genes (Mathur and Yang 2015). However, more than 50\% of USH cases (Bonnet et al. 2011, Lenarduzzi et al. 2015), as well as $8 \%$ of non-syndromic autosomal recessive RP (ARRP) patients (Hartong et al. 2006), harbor mutations in the USH2A gene, which is therefore the principle gene responsible for both diseases. This is due, in part, to the high prevalence of two mutations located 22 bp from each other in exon 13: c.2299delG/p.E767Sfs*21, which accounts for up to $31 \%$ of USH2 cases, and c.2276G $>$ T/p.C759F, which is found in approximately $4.5 \%$ of ARRP cases (Aller et al. 2004, Baux et al. 2014).

The large size, up to $15 \mathrm{~kb}$, of the USH2A coding sequence (GenBank: NM_206933) makes it difficult to develop a gene substitution therapy for patients with mutations in this gene. In addition, more than one essential isoform of the USH2A gene is expressed in the retinal tissue, and augmentation therapy by delivery of one single cDNA would be insufficient (Williams et al. 2017). Nevertheless, a suitable alternative now exists: genetic correction using gene editing strategies such as the CRISPR/Cas9 system, which holds enormous promise for in vivo and ex vivo genome editing-based therapies (Cox et al. 2015, Dai et al. 2016, Long et al. 2016, Nelson et al. 2016, Tabebordbar et al. 2016). Furthermore, the close proximity of the two highly prevalent mutations in exon 13 of USH2A is convenient for using this particular technology.

CRISPR-associated endonuclease Cas9 protein is an up-to-date technology that has recently been implemented for use in a broad spectrum of cell types and model organisms (Cong et al. 2013, Doudna and Charpentier 2014, Hsu et al. 2014, Sander and Joung 2014). The system comprises two primary elements that form the RGEN (RNA-guided engineered nucleases) complex(Deltcheva et al. 2011, Jinek et al. 2012): namely, the Cas9 nuclease and 
a single guide RNA molecule (sgRNA or guide RNA) (Figure 1A). The latter is specifically designed to be complementary to the target locus (Figure 1B).

A

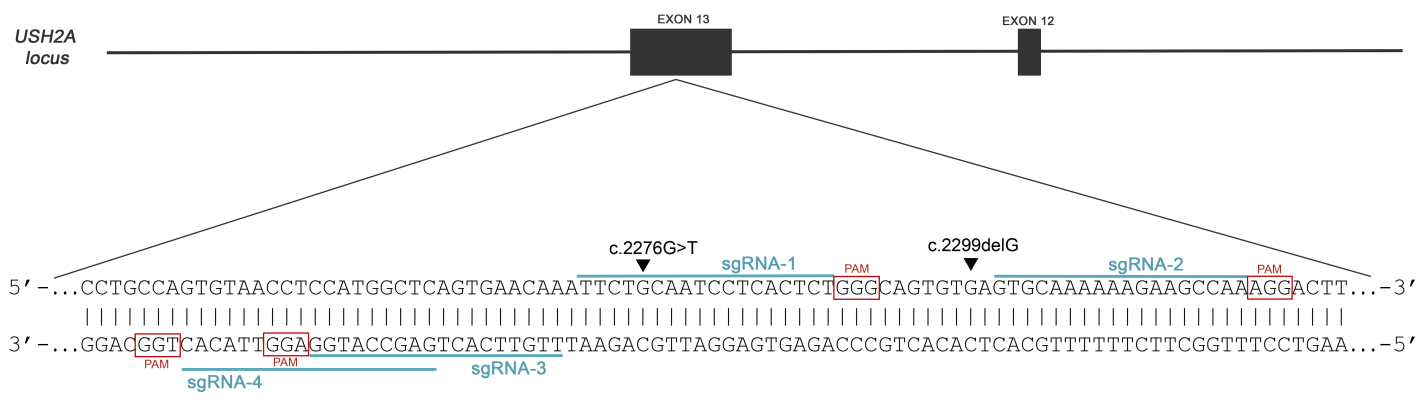

B

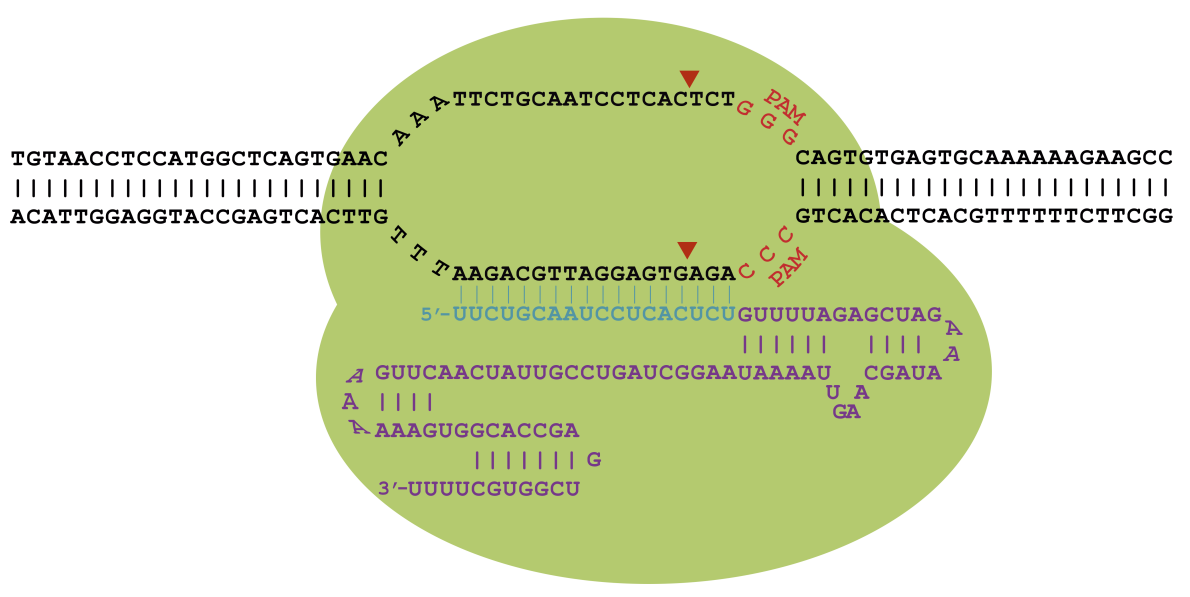

Figure 1. Diagram Showing the CRISPR Construct Designs for the USH2A Locus Editing. (A) Exon 13 of USH2A highlighting the location of mutations c.2299delG and c.2276G $>T$, as well as the four different sgRNAs (blue) selected to target the locus. Red boxes indicate PAM sequences 30 -adjacent to the sgRNAs. (B) The CRISPR/Cas 9 system relies on the Cas9 nuclease and the sgRNA, and this last molecule consists of two RNA domains: crispr RNA (crRNA), which is specifically designed to be complementary to the target locus (blue), and trans-activating crRNA (tracrRNA), which is more a structural part for the binding with the nuclease (purple). The scheme represents the Cas9 endonuclease-sgRNA-1 complex (RGEN-1): the RNA couples with Cas9 endonuclease (green outline), forming the complex known as RGEN (RNA-guided engineered nucleases), and guides it to the sgRNA complementary sequence of the target DNA through Watson-Crick base pairing, enabling the Cas9 to produce a double-stranded break (DSB) in the DNA (red arrowheads). In addition, in order for the Cas9 to recognize and site-specifically cleave the DNA, a specific short pattern needs to be present 30 -adjacent to the target sequence: the protospacer adjacent motif (PAM), consisting of the 3 bases 50 -NGG (shown in red).

Upon cleavage by Cas9, the target locus typically undergoes one of two major pathways for DNA damage repair: the error-prone non-homologous end joining (NHEJ) or the homology-directed repair (HDR) pathway (Barnes 2001, van den Bosch et al. 2002), both of 
which can be used to achieve the desired editing outcome. In the absence of a repair template with identical homologous flanking ends, the HDR pathway cannot be employed. Thus, double-stranded breaks (DSBs) are re-ligated by means of the NHEJ mechanism, leaving scars in the form of insertion/deletion mutations (indels), which indirectly represent the Cas9 cleavage efficiency.

Due to its high efficacy and simple design, we have employed the CRISPR/Cas9 system in this study for $U S H 2 A$ gene manipulation, with the aim of repairing the most prevalent mutations present in this gene. Through this study, the locus where the mutations c.2299delG and c.2276G > T in exon 13 of USH2A are located has been edited.

\section{Results}

\section{USH2A Exon 13 Editing in HEK293 Cells}

The aim of this study was to set up a CRISPR toolkit to correct the c.2299delG and c.2276G > T mutations in cells from patients harboring these mutations. Editing primary cell lines is known to be difficult. For that reason, the broadly used HEK293 cells were selected for the first trial, since they are easy to handle and transfect. However, this cell line presents a wild-type (WT) genome; to overcome this problem, a decision was made to reverse the strategy by introducing the c.2299delG and c.2276G > T mutations in these cells instead of their correction.

Four different 18-nt-long RNA guides (sgRNAs) were designed to drive Cas9 to the target exon 13 of the USH2A gene, where mutations c.2299delG and c.2276G > T are located. Two were set on the positive strand (sgRNA-1 and sgRNA-2) and two were set on the negative strand (sgRNA-3 and sgRNA-4) (Figure 1A). These sequences were cloned into the pX330 vector containing all the primary elements of the CRISPR system (Cong et al. 2013).

The resultant constructs were transfected into HEK293 cells. $48 \mathrm{hr}$ post-transfection, the cells were lysed to extract the genomic DNA (gDNA) and analyze the cleavage efficiency of each sgRNA by the T7-endonuclease I (T7E1) assay. Results from the T7E1 assay demonstrated that the four Cas9-sgRNA plasmids exhibited cleavage activity at both DNA concentrations used ( $1 \mu \mathrm{g}$ and $3 \mu \mathrm{g}$ ) (Figure 2A). However, transfection with $3 \mu \mathrm{g}$ DNA produced better results: sgRNA-1 had around $40 \%$ and $53 \%$ on-target cleavage efficiency at transfection concentrations of $1 \mu \mathrm{g}$ and $3 \mu \mathrm{g}$ respectively. The sgRNA-2 was almost as effective, with $30 \%$ on-target activity with $1 \mu$ g product transfection and $52 \%$ with the higher dose. The sgRNA-4 showed similar results to sgRNA-1, with 39\% cleavage efficiency at $1 \mu \mathrm{g}$ 
transfection and $54 \%$ after the concentration increase. Finally, sgRNA-3 was the less effective construct, with a cleavage activity below $10 \%$ for both conditions. The efficiency of the sgRNA-1 $(3 \mu \mathrm{g})$ was confirmed through Sanger sequencing of the clonal isolated amplicons (Figure 2B) (Ran et al. 2013b), presenting a cleavage activity of $62 \%$ based on the indel mutations detected in these sequences.

A

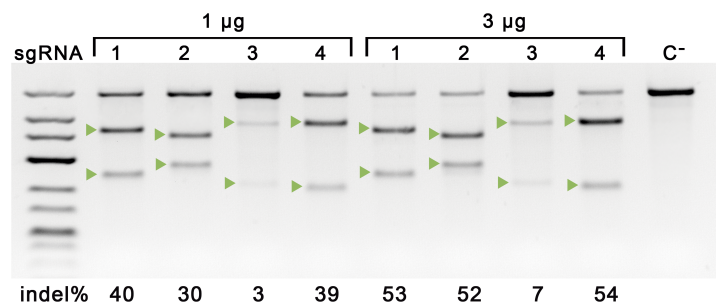

B

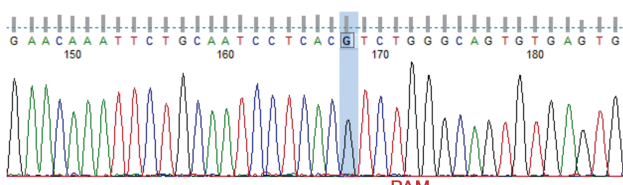

WT...GAACAAATTCTGCAATCСTCACTCT TAM TCAGTGTGAGTG... GAACAAATTCTGCAATCCTCACGTCTGGGCAGTGTGAGT G GAACAAAT TCTGCAA - - - - - TCTGGGCAGTGTGAGTG GAACAAAT TCT $-\cdots$ GAACAAATTCTGCAATCCTCA-TCTGGGCAGTGTGAGTG GAACAAATTCTGCAATCCTCACCTCTGGGCAGTGTGAGTG GAACAAATTCTGCAATCCTCAC-----GTGTGAGTG GAACAAATTCTGCAATCCTCACATCTGGGCAGTGTGAGTG GAACAAATTCTGCAATCCTCACT--GGGCAGTGTGAGTG

Figure 2. CRISPR Assay on HEK293 Cells. (A) Products of the T7E1 assay resolved on a 2\% agarose gel. Green arrowheads indicate cleaved bands corresponding to the expected fragments resulting from T7E1 cutting, the intensity of which is directly correlated to the indel frequency and therefore for Cas9 on-target activity. Untreated genomic DNA from the same HEK293 cells used for transfections was used as a negative control, where only the intact band can be observed. (B) Chromatograms showing the result of Sanger sequencing of PCR products obtained after amplifying genomic DNA, and subcloned into a plasmid for E. coli transformation, from cultures transfected with RGEN-1 at $3 \mu \mathrm{g}$. The indels shown here are produced by NHEJ repair. The indel frequency was established by comparison with the wild-type (WT) reference sequence. Red arrowheads point out the most probable cutting position on the sgRNA sequence (bold characters), 3-4 bp upstream of the PAM sequence (shown in red). NHEJ results in small deletions (bold green dashes) or in insertions (green bold characters). The chromatogram illustrates an example of the first NHEJ event with a G insertion framed in the blue background.

To introduce the c.2299delG and c.2276G > T mutations in WT HEK293 cells through the HDR major DNA repair pathway, the sgRNA-1 construct was selected, since it had shown a higher activity and is located closer to the mutations. HDR typically occurs at lower and substantially more variable frequencies than NHEJ; nevertheless, it can be used to generate precise, defined modifications at a target locus in the presence of an exogenously introduced repair template (Gong et al. 2005, Doudna and Charpentier 2014). A repair template in the form of a single-stranded oligodeoxynucleotide (sSODN) was utilized (Figure $3 \mathrm{~A})$, which provides an effective and simple method for making small edits in the genome (Storici et al. 2006, Radecke et al. 2010, Chen et al. 2011, Ran et al. 2013b). HEK293 cells were separately transfected with $3 \mu \mathrm{g}$ sgRNA along with an ssODN carrying either the c.2299delG mutation (ssODN-2299) or the c.2276G $>T$ mutation (ssODN-2276). In addition to the 
specific mutation, the designed ssODNs had a change in the protospacer adjacent motif (PAM) sequence to remove the sequence pattern, consisting of a silent mutation ( $\mathrm{G}$ to $\mathrm{C}$ transversion) that lacked splicing alterations based on computational prediction tools. This introduced a restriction site, which is useful for a restriction fragment length polymorphism (RFLP) analysis of the genomes of the edited cells.

The analysis by digestion with MIsl of the PCR products of exon 13 from gDNA from targeted cells showed considerable results of HDR for both construct-template combinations. These products were resolved through RFLP analysis and subsequent image quantification through relative band intensities. When using SSODN-2299delG, HDR efficiency reached $16 \%$, whereas co-transfection with ssODN-2276 showed $12 \%$ effectiveness (Figure 3B).

A
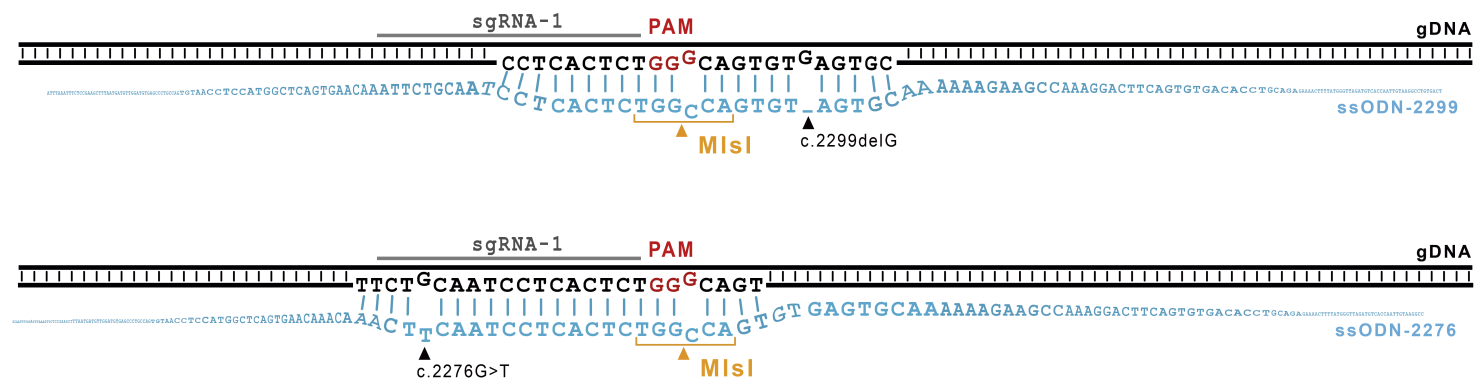

B

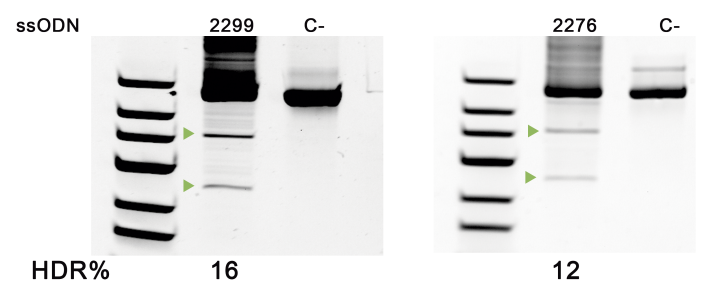

Figure 3. Exon 13 Is Efficiently Edited in HEK293 Cells with sgRNA-1. (A) Diagram depicting the targeted region and the two specific ssODNs used as an exogenous template for repair. The 193-nt-long ssODN-2299 is shown above, highlighting the guanine deletion corresponding to the c.2299 position. Below, the 197-nt-long ssODN-2276 presents a similar composition, but with c.2276G >T change instead of the c.2299delG. The diagram also displays the silent mutation c.2292G >C placed in both ssODN designs. This variant is located in the PAM sequence to avoid recognition of the target by the sgRNA, and, therefore, to be cleaved by Cas9. Moreover, this variant creates the new recognition site for the Mlsl restriction enzyme for the edition detection. (B) RFLP results of HEK293 transfection with $3 \mu \mathrm{g}$ sgRNA-1 together with 10 pmol of the ssODN including either the mutation c.2299delG or c.2276G > T. Green arrowheads indicate fragments cut by the restriction enzyme Mlsl. 


\section{Correction of the c.2299delG mutation in fibroblasts}

Human dermal fibroblasts (HDFs) were isolated from an USH2 patient carrying the c.2299delG mutation in homozygosis, as well as from two healthy control patients. Unfortunately, cells carrying the c.2276G $>T$ mutation in homozygosis could not be obtained.

The CRISPR activity in control fibroblasts using the DNA constructs was undetectable (data not shown); hence, we used ribonucleoprotein (RNP) complex delivery, consisting of purified Cas9 protein coupled with the in vitro transcripted (IVT) sgRNA. A combination of $15 \mu \mathrm{g}$ Cas9 and $20 \mu \mathrm{g}$ sgRNA-1 was transferred to control HDFs as RNP complexes by nucleofection obtaining an indel frequency of $18 \%$ (Figure $4 \mathrm{~A}$ ). The subsequent edition attempt using co-delivery of RNPs with ssODN-2299 resulted in 5\% HDR efficiency (Figure 4B).

In view of the promising results, the same process was performed on c.2299delG patient HDFs using an SSODN with a WT sequence and the PAM sequence ablated (ssODN-WT) (Figure 4C). An indel frequency of $6 \%$ and an HDR mutation correction of $2.5 \%$, according to image quantification, were achieved (Figures $4 \mathrm{~A}$ and $4 \mathrm{~B}$ ).

A

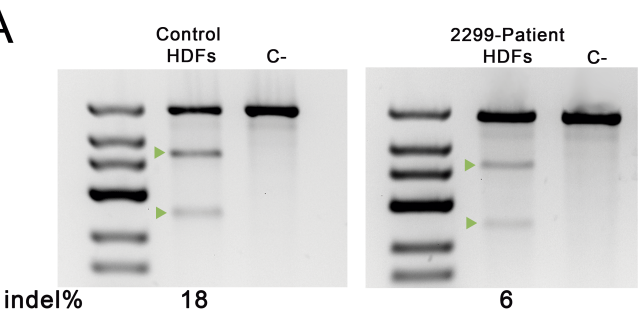

B

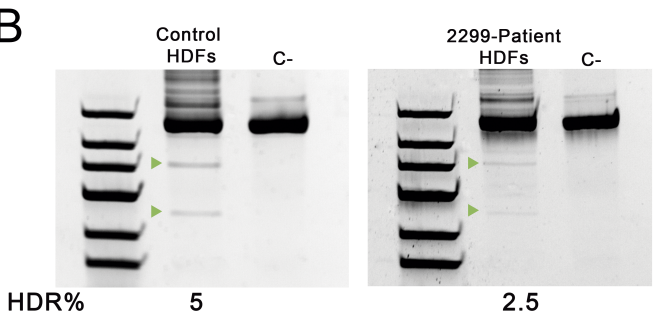

C

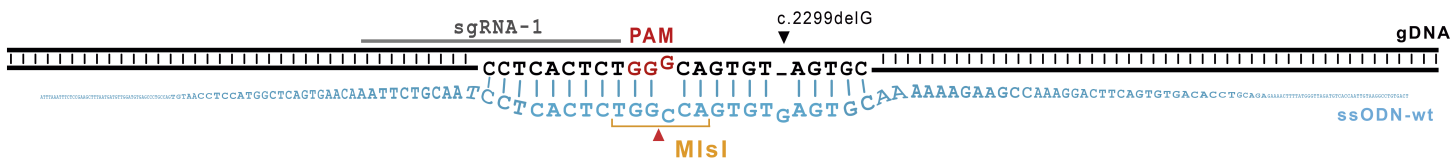

Figure 4. Editing of HDFs. (A) T7E1 assay resolved on a 2\% agarose gel with HDF amplification products, noting the cleaved fragments corresponding to indels (shown with green arrowheads). Untreated genomic DNA from the same HDF cells used for transfections was used as a negative control, where only the intact band can be appreciated. (B) RFLP assay results of the HDF transfection with $15 \mu \mathrm{g}$ Cas 9 and $20 \mu \mathrm{g}$ sgRNA-1 with 500 pmol of the SSODN with the wild-type sequence lacking the PAM. Green arrowheads show fragments cut by the restriction enzyme MIsI. (C) Scheme depicting the targeted region and the 194-nt ssODN-WT with the guanine restoration on the c.2299 position. The silent mutation c.2292G >C was included in the ssODN design in order to prevent Cas9 cleavage as well as the MlsI target sequence for the edition detection by RFLP. 


\section{Analysis of edition rates using high-throughput sequencing}

Cas9 presents a certain capability to cleave on DNA sites differing from some nucleotides in the sgRNA sequence (Lin et al. 2014b), causing collateral off-target mutations that should be taken into consideration.

The resulting potential off-target ensemble obtained from the in silico prediction tools consisted of a total of 21 off-targets (Table 1 ) to be screened through high-throughput sequencing, since the T7E1 assay is only sensitive to mismatches above 1\% (Kim et al. 2009).

Amplicon deep sequencing of the treated cells using the Illumina MiSeq platform, allowed for the validation of on-target Cas9 cleavage by indel detection, as well as the effective c.2299delG mutation correction by HDR (Figure 5). Reads inspection exposed $20.1 \%$ of the specific target cleavage and $1.7 \%$ of direct edited sequences harboring only the two directed variants included in the ssODN-WT design (c.2299insG and c.2292G >C). Furthermore, some sequences presenting only one of the two variants were detected and these were considered as partially edited.

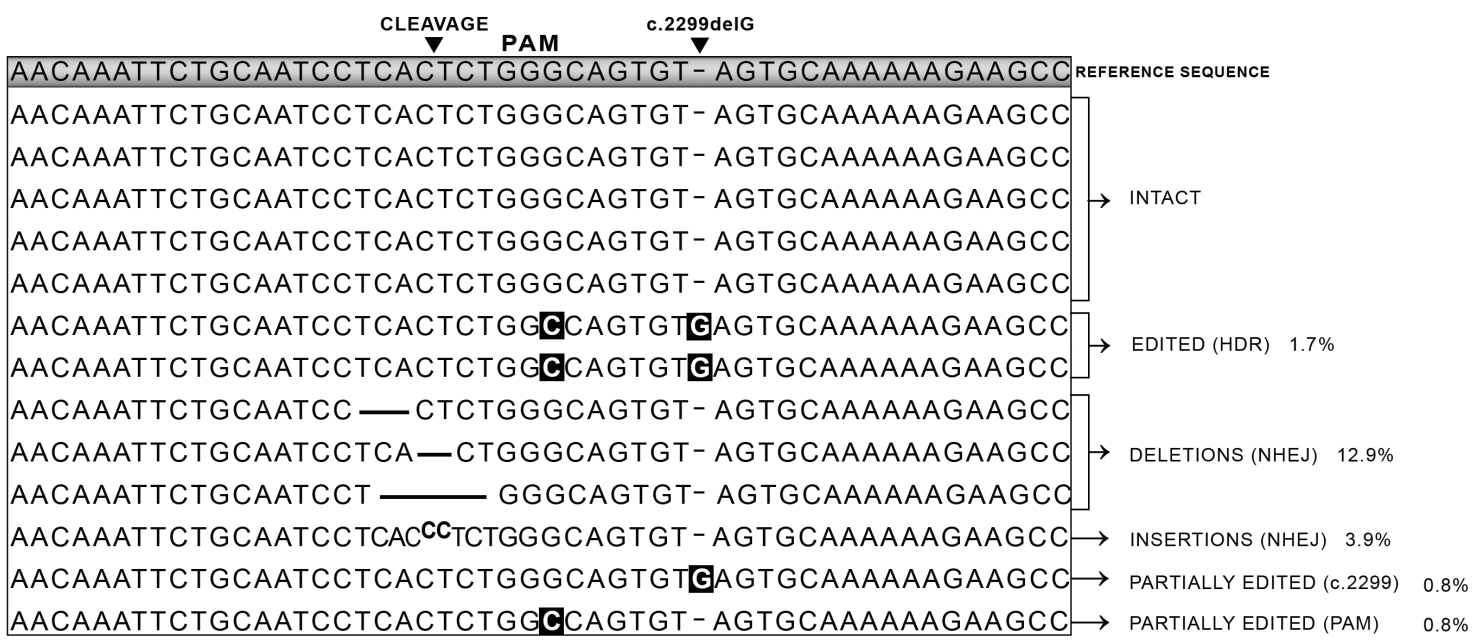

Figure 5. Deep sequencing of the HDFs transfected with RGEN-1 plus ssODN-WT. Representation of real sequencing reads mapped against the USH2A locus, showing examples of the different editing possibilities obtained with RGEN-1: Cas9-specific action is appreciated by the small insertions (bold superscripted characters) or deletions (bold dashes) upstream of the PAM sequence, due to the NHEJ repair mechanism. Directed editing events of the exon 13 of USH2A are represented by sequences that contain the c.2299delG mutation correction, as well as the silent G>C transversion in the PAM sequence (directed changes highlighted in black background). Sequences with only one of the aimed changes are considered partially edited. RGEN-1 cleavage efficiency is estimated as the number of all sequences that are different from the reference sequence of the patient (20.1\%; i.e., the sum of the edited, partially edited, and indel carrying sequences). Reads identical to the reference sequence correspond to intact cells where Cas9 had no cleavage activity. 
On the other hand, no detectable off-target activity was identified for almost all potential loci, since no significant number of reads with indels on the potential cutting area was tracked. Unfortunately, sequences from one of the tested loci (SLX XIP locus) were not captured by the sequencing platform; therefore, no data could be obtained from this region. Nevertheless, this region presents a minor site recognition probability according to the ranking list (Table 1 ) and since none of the other targets showed cleavage activity, it seems unlikely that this locus should behave otherwise.

Table 1. Selection of in silico potential off-targets for sgRNA-1

\begin{tabular}{|c|c|c|c|c|c|c|}
\hline Position $^{a}$ & Gene & locus type & Sequence & Strand & Mismatches & Bulge size \\
\hline chr13:36343748 & SPG2O & intronic & TTaTCCAATCCTCACTCTTGG & positive & 2 & 0 \\
\hline chrX :31429579 & $D M D$ & intronic & TTCTGgAATgCTCACTCTGGG & negative & 2 & 0 \\
\hline chr1:63817856 & $R O R 1$ & intronic & TTCTGCAtTCCTCcCTCTTGG & positive & 2 & 0 \\
\hline chr3:60966504 & FHIT & intronic & TTCTGCACTCCTCACgCTGGG & positive & 2 & 0 \\
\hline chr5:168083516 & TENM2 & intronic & TTCTGCAATgCTCACaCTGGG & positive & 2 & 0 \\
\hline chr8:98710205 & STK3 & intronic & TTCTGCAATgCTCACgCTGGG & negative & 2 & 0 \\
\hline chr2:161421064 & TBR1 & intronic & TTCTGCAATtCTCACTCaGGG & positive & 2 & 0 \\
\hline chr5:64594732 & $R G S 7 B P$ & exonic & TTtTGCAATCCaaACTCTTGG & negative & 3 & 0 \\
\hline chr11:64851825 & $E H D 1$ & UTR & TTCgGCAgTCCTCAgTCTCGG & positive & 3 & 0 \\
\hline chrX:24006521 & KLHL15 & exonic & TTCTGaAgTaaTCACTCTGGG & positive & 4 & 0 \\
\hline chr15:81827587 & - & intergenic & TTCTGCAATCCTCA ${ }^{G}$ CTCTTGG & positive & 0 & 1 \\
\hline chr11:62715832 & HNRNPUL2-BSCL2 & intronic & TTCTGC--TCCTCACTCTGGG & negative & 0 & 2 \\
\hline chr17:997306 & TIMM22 & exonic & TTCTGC--TCCTCACTCTTGG & negative & 0 & 2 \\
\hline chr17:63411113 & TANC2 & intronic & TcCTGC-ATCCTCACTCTTGG & negative & 1 & 1 \\
\hline chr5:135075878 & C5orf66 & intronic & TT-TGCAATtCTCACTCTGGG & positive & 1 & 1 \\
\hline chr2:52242405 & LOC730100 & intronic & TTCTGCAATtC-CACTCTTGG & positive & 1 & 1 \\
\hline chr2:159450247 & $B A Z 2 B$ & intronic & TTCTGtAATCCTCACT ${ }^{A}$ CTCGG & positive & 1 & 1 \\
\hline chr2:89267421 & IGKVI-33 & intronic & TTCTGCAgTCCTCAC-CTCGG & negative & 1 & 1 \\
\hline chr2:89915107 & IGKV1D-33 & intronic & TTCTGCAgTCCTCAC-CTCGG & positive & 1 & 1 \\
\hline chr16:7651515 & RBFOXI & intronic & TTCTGCAACCCTCAC-CTGGG & positive & 1 & 1 \\
\hline chr20:10492244 & $S L X 4 I P$ & intronic & TTCTGCAATCC-CACTCCAGG & negative & 1 & 1 \\
\hline \multicolumn{7}{|c|}{$\begin{array}{l}\text { Position, chromosomal coordinates according to GRCh38 (Genome Reference Consortium Human Build 38); lower-case letters, } \\
\text { mismatches; superscripted characters, DNA bulge position; dashes, RNA bulge position; and bulge size, the presence of a bulge } \\
\text { and the size of the loop. } \\
\text { a Off-targets are arranged according to the recognition probability based on the mismatch-bulge display and proximity to the } \\
\text { PAM. In the case of equal conditions, a chromosomal position numerical order is applied. }\end{array}$} \\
\hline
\end{tabular}




\section{Discussion}

USH is a disorder that heavily impairs the social and cognitive development of patients, since nowadays in developed countries communication is based on media. This is a major handicap for people with hearing and vision problems, interfering with their educational and intellectual development and eventually leading to a hampering of professional integration. To date, there is no medical treatment except hearing aids or cochlear implants for audiological disabilities, so new therapies are being explored to cure or alleviate RP symptoms. Gene replacement therapies could be a potential treatment if it were not for the large size of USH2A. The limited cargo capacity of the most widely used viral vectors such as adeno-associated viruses (AAVs) could be bypassed using helper-dependent adenoviruses (Hd-Ads) or herpes simplex viruses (HSVs) as gene carriers that are able to accommodate larger sequences, with respective cargo limits up to $36 \mathrm{~kb}$ and $150 \mathrm{~kb}$ (Parks et al. 1996, Hibbitt and Wade-Martins 2006, Melendez et al. 2014). However, these viral vectors have particular restrictions that directly concern this case study. Hd-Ad and HSV have been reported as transducing primarily the retinal pigment epithelium (RPE) but in a very limited way or not at all the photoreceptors (PR) (Fraefel et al. 2005, Kumar-Singh 2008), apart from some Ad engineered vectors without a persistent transgene expression that require systematic infections with the construct (Cashman et al. 2007). In addition, the large size of these vectors makes trespassing through the inner plexiform layer very difficult, not permitting intravitreal administration but only the more invasive subretinal injection.

A genome editing therapeutic approach could be a suitable alternative to safely correct the specific mutations of each patient. Various genome editing technologies have emerged in recent years, including zinc-finger nucleases (ZFNs), transcription activator-like effector nucleases (TALENs), and the CRISPR/Cas9 nuclease system. The first two technologies use a strategy of tethering endonuclease catalytic domains to modular DNA binding proteins for inducing targeted DNA DSBs at specific genomic loci (Mortensen 2007). By contrast, Cas9 is a nuclease guided by small RNAs through Watson-Crick base pairing with target DNA, representing a system that is markedly easier to design, highly specific, and efficient for a variety of cell types and organisms (Burgess 2013). Using a direct mutation repair strategy like engineered nucleases represents a new panorama for future therapies. In this study, the most prevalent mutation involved in USH, c.2299delG, has been edited. This mutation is responsible for USH in a considerable number of patients.

This study has demonstrated successful targeting of exon 13 of USH2A in HEK293 cells with CRISPR, allowing for the editing of the locus to introduce the c.2299delG and 
c.2276G > T mutations. However, the approach utilizing DNA constructs was unsuccessfully transferred to control HDFs, most probably due to the hard-to-transfect feature of the fibroblasts, in addition to the fact that the isolated cells are not neonatal but are from adult donors. This issue was addressed by transferring the RGEN designs from plasmids to preassembled Cas9-sgRNA (RNPs) cell delivery, a method that offers a host-transcriptome-free option. This method has previously been reported as an efficient alternative that also provides the advantage of a reduction in off-target events because of the short lifespan of these RNP complexes, compared to the continuous expression of the elements providing plasmid transfection (Kim et al. 2014, Lin et al. 2014a, Liang et al. 2015, Kouranova et al. 2016).

In this project, high indel frequencies were achieved with 3 of the 4 designed sgRNAs in HEK293 cells. sgRNA-3 is the only construct showing low cleavage activity, which may be due to the locus accessibility. Structural or epigenetic arrangements such as methylation patterns have previously been reported to hinder Cas9-sgRNA attachment to the DNA (Chen et al. 2016, Vojta et al. 2016). Other studies suggest that sgRNAs targeting the active strand show a higher cleavage efficiency compared to those targeting the inactive strand (Song and Stieger 2017). Nevertheless, if we accept this statement, sgRNA-4 should have shown a lower NHEJ efficiency instead of rates similar to sgRNA-1 and sgRNA-2. We suspect that the sgRNA-3 failure could be affected by any of these phenomena or by other still unknown aspects regarding the CRISPR/Cas9 system.

Substantial editing rates were achieved on HEK293 and more limited percentages on HDFs. Editing differences between the fibroblasts of the control ( $18 \%$ indel and $5 \%$ HDR) and USH patients ( $6 \%$ indel and $2.5 \%$ HDR) may be due to a survival detriment associated with the c.2299delG mutation, but other explanations cannot be ruled out. The discrepancies between the RFLP and the deep-sequencing rates have led to further analyses being performed with the next-generation sequencing (NGS) data, resulting in interesting findings. A small number of sequences presented either c.2292G $>C$ silent change or c.2299G insertion in equal proportions ( $0.8 \%$ each), suggesting that HDR is rendered in some cases with one end of the template or the other. Partially edited fractions with only the PAM change would be recognized in the RFLP assay, since the MlsI target sequence would be generated as well. Therefore, when we compute this rate $(0.8 \%)$ along with the absolute edited cells registered by deep sequencing (1.7\%), the percentage approximates to the results obtained by RFLP (2.5\%). Similarly, the partially edited cells for only the c.2299delG repair $(0.8 \%)$ could be taken into account along with the whole edited sequences number 
(1.7\%), inferring a $2.5 \%$ rate of mutation correction (Figure 5). These data, therefore, show evidence of in vitro genomic editing of the pathological mutation c.2299delG in fibroblasts from patients. It has to be noted that HDFs are considered to be refractory to transfection, so that the exogenous DNA is rapidly excluded from the nucleus hindering HDR (Coonrod et al. 1997). In addition, HDFs from adult skin biopsies are less pliant than those used in other studies from newborn cell lines, where authors achieve similar or lower editing rates (Kim et al. 2014, Lin et al. 2014a). For that reason, we consider that our knock-in results are high compared with those described in the literature, giving grounds for optimism for future therapeutic implementation of this technology in USH.

Concerning the cleavage frequency differences observed in the HDFs of the USH patient (6\% in the T7E1 assay versus $20.1 \%$ in the deep-sequencing results; Figures $4 \mathrm{~A}$ and 5 , respectively), these are thought to be due to the correction equation used to calculate the indel percentage based on the T7E1 assay (see the Materials and Methods), which may be excessively conservative. If we do not use this formula, the cleavage efficiency on HDFs increases from $6 \%$ to $12 \%$, resembling more the $20.1 \%$ count based on deep-sequencing data.

The retina has emerged as an increasingly promising tissue for genome editing-based and cell transplantation therapies, owing to its unique features as a surgically accessible, immune privileged organ that can be non-invasively imaged. The development of sitespecific CRISPR-based genome editing approaches to correct the genetic mutation causing blindness will provide potential strategies for future gene therapy in patients.

There are a number of researchers carrying out preclinical studies using induced pluripotent stem cells (iPSCs) or photoreceptor cells for transplantation in the retina (Gonzalez-Cordero et al. 2013, Pearson et al. 2016), but these approaches still have limitations. In the case of autologous transplants, the replacement cells still carry the mutations responsible for the pathology and are thus a short-term solution. Otherwise, the use of donor cells carries the usual risk of tissue rejection (Gonzalez-Cordero et al. 2013, Pearson et al. 2016). Another alternative strategy would be to use the CRISPR/Cas9 system on the iPSCs prior to transplantation in order to deliver repaired self-donated cells into the retina (Grobarczyk et al. 2015, Li et al. 2016, Ou et al. 2016). However, producing and maintaining iPSCs from fibroblasts is expensive and time-consuming; therefore, attempting gene targeting in these cells may not be affordable for laboratories lacking the necessary expertise. With reference to this issue, several groups have claimed successful iPSC-derived photoreceptor progenitor (PhRP) transplantations in animal models, which form functional 
synapses with the host bipolar cells and partially restore visual function based on electrophysiology and anatomical diagnosis (Homma et al. 2013, Tucker et al. 2013, BarneaCramer et al. 2016). In contrast, feasible visual recovery on human translation still remains unproven and many questions need to be answered before these techniques can be transferred to clinical trials for RP patients.

An ultimate option would be the in vivo photoreceptor targeting with CRISPR and, for that purpose, different methods are currently being tested such as AAV-based delivery strategies or even other carriers for RNPs like nanoparticles, cell-penetrating peptides, exosomes, or liposomes (Mishra et al. 2011, Li et al. 2013, Zhang et al. 2014, Ran et al. 2015, Han et al. 2016, Lee et al. 2016, Wang et al. 2016, Huang et al. 2017, Zhao et al. 2017). Utilizing these non-viral vehicles for delivery would likely lead to a less toxic approach, also allowing for the benefit of preserving the previously designed RNP protocol from the present study.

The HDR rate achieved in this study with HDFs is still too low to be considered for an in vivo procedure. Other strategies that should be investigated for increasing HDR efficiencies have been developed in recent years, such as the use of chemically modified or asymmetric sSODNs or the addition of NHEJ inhibitors to the culture medium (Maruyama et al. 2015, Renaud et al. 2016, Richardson et al. 2016). Another controversial issue worth considering is the fact that post-mitotic cells are considered as lacking the HDR-mediated repair mechanism (Ran et al. 2013b), yet recent studies have detected HDR in retinal pigment epithelial cells and developed adult photoreceptors (Williams et al. 2017). Nevertheless, even if HDR is considered as non-active, it has also been demonstrated that non-dividing cells do have a repair mechanism in the form of transcription-coupled homologous recombination (Wei et al. 2016), enabling a repair pathway through an RNA template instead of ssODNs. The only major hindrance in using this technique would be the remote chance of introducing a mutation at potential off-target sites, thereby resulting in oncological consequences. However, the design of this project indicated no evidence for off-target activity from the final treated cells. In addition, some studies relating to this dilemma have recently been published, offering improved Cas9 engineered versions with an off-target reduction, such as eSpCas9(1.1) or SpCas9-HF1 (Kleinstiver et al. 2016, Slaymaker et al. 2016). NHEJ repair would still outline HDR, but since USH is an autosomal recessive disease and both gene alleles are already nonfunctional, the possible non-repaired indel scar would have a neutral impact on the photoreceptor phenotype of the patients.

Some attempts to correct the underlying genetic defect of USH, such as the use of antisense oligonucleotides (AONs) or cDNA supplementation (Lopes et al. 2013, Slijkerman 
et al. 2016), are ongoing. Furthermore, a study was recently published where the visual function of an RP animal model seemed to be restored after correcting the genetic cause by CRISPR/Cas9 techniques (Suzuki et al. 2016). In conclusion, the present study demonstrates for the first time that correcting the two most prevalent mutations of USH is feasible using the CRISPR/Cas9 system and homologous recombination, thereby offering future promise for repairing these and other mutations in cells from patients.

\section{Materials and Methods}

This study was approved by the University Hospital La Fe Research Ethics Committee.

\section{Design of the sgRNAs}

Four different sgRNAs (more specifically, the crRNA domain) were designed according to the following criteria: close location to the mutation(s); following PAM at the 3 ' end; and 18-nt length, since it has been demonstrated that a 2-nt shortening in the sequence length brings higher specificity rather than the initially proposed 20-nt design (Fu et al. 2014).

\section{Plasmid constructions}

The sgRNA consists of two RNA domains: crispr RNA (crRNA), which is specifically designed to be complementary to the target locus, and the constant trans-activating crRNA (tracrRNA), which is required for coupling with the Cas9 nuclease.

In order to create each Cas9-sgRNA construct, crRNAs were cloned in pX330-U6Chimeric_BB-CBh-hSpCas9 (a gift from Feng Zhang, plasmid no. 42230; Addgene). The two opposite Bbsl restriction sites were used to insert the guide under the control of a U6 promoter and were then linked to the tracrRNA sequence. For this purpose, selfcomplementary oligonucleotides (Integrated DNA Technologies, IA, USA) with the corresponding crRNA sequences were annealed by gradual cooling with prior denaturalization at $94^{\circ} \mathrm{C}$. The duplex oligonucleotides with the crRNA sequences also presented cohesive ends with the 3' overhangs left after pX330 incubation with the Bbsl restriction enzyme, serving for the ligation of the insert-plasmid with T4 DNA ligase (EL0014; Thermo Fisher Scientific, Waltham, MA, USA). Top10 E Escherichia coli electrocompetent cells were transformed by electroporation with each of the plasmid constructs for their plate selection and amplification in liquid culture. The vectors were purified using a HiSpeed 
Plasmid Midi Kit (no. 12643; QIAGEN, Hilden, Germany) and were Sanger sequenced to verify the correct cloning of the specific crRNA inserts.

\section{HEK293 cell culture and transfections}

HEK293 cells were maintained at $37^{\circ} \mathrm{C}$ and $5 \% \mathrm{CO}_{2}$ in DMEM high glucose without Lglutamine without sodium pyruvate medium (Biowest SAS, Nuaillé, France) supplemented with $10 \%$ fetal bovine serum (FBS) (Biowest) and $1 \%$ penicillin-streptomycin (PS) solution 100x (Biowest).

For the functional validation of the RGEN activity, $5 \times 10^{5}$ HEK293 cells were separately transfected with each of the plasmid constructs at $1 \mu \mathrm{g}$ and $3 \mu \mathrm{g}$ concentrations using Lipofectamine 3000 (no. L3000001; Invitrogen, Carlsbad, CA, USA).

For the directed edition, $3 \mu \mathrm{g}$ RGEN was delivered to $5 \times 10^{5}$ HEK293 cells along with 1 $\mu \mathrm{l}$ of the pertinent ssODN at $10 \mu \mathrm{M}(10 \mathrm{pmol})$. Parallel GFP transfections were carried out in all transfection assays as positive controls. All experiments were assayed in duplicate.

\section{T7-Endonuclease 1 assay}

The widely used T7-endonucelase I assay targets and digests heteroduplexes formed by hybridization of mutant WT strands resulting in two smaller fragments (Guschin et al. 2010), and this method was performed to assess sgRNA-specific activity.

After transfection, cells were incubated for $48 \mathrm{hr}$. The cells were then pelleted and resuspended in $10 \mu \mathrm{l}$ of PBS. For lysis, $20 \mu \mathrm{l}$ lysis buffer $(0.3 \mathrm{mM}$ Tris $/ \mathrm{HCl}, 0.6 \mathrm{mM} \mathrm{CaCl} 2,1.5 \%$ glycerol, $0.675 \%$ Tween $20,0.3 \mu \mathrm{g} / \mu \mathrm{l}$ proteinase $\mathrm{K}$, and $0.954 \% \mathrm{H}_{2} \mathrm{O}$ ) were added and the suspension was treated at $65^{\circ} \mathrm{C}$ for $30 \mathrm{~min}, 90^{\circ} \mathrm{C}$ for $10 \mathrm{~min}$, and then cooled for $4^{\circ} \mathrm{C}$. Finally, $30 \mu \mathrm{l}$ of $\mathrm{H}_{2} \mathrm{O}$ was added to the lysed product. The target locus was amplified for 35 cycles

with specific forward (5'-GGCATTGCTTGTGAGAAAACAC-3') and reverse (5'CAGATGTGTGAGTGTGATTCCT-3') primers targeting exon 13 of the USH2A locus with KAPA HiFi HotStart DNA Polymerase (no. KK2501; Kapa Biosystems, Wilmington, MA, USA). These PCR products were gel purified using the E.Z.N.A. Gel Extraction Kit (no. D2500-02; Omega Bio-tek, Norcross, GA, USA). For heteroduplex formation, $200 \mathrm{ng}$ purified DNA amplification was denatured and then reannealed using the following program: $95^{\circ} \mathrm{C}$ for $5 \mathrm{~min}$, ramp down to $85^{\circ} \mathrm{C}$ at $-2^{\circ} \mathrm{C} / \mathrm{s}$, and ramp down to $25^{\circ} \mathrm{C}$ at $-0.1^{\circ} \mathrm{C} / \mathrm{s}$. At this step, $1 \mu \mathrm{lT}$ endonuclease I (no. M0302S; New England Biolabs, Ipswich, MA) was added to the mix and incubated for $15 \mathrm{~min}$ at $37^{\circ} \mathrm{C}$. The reaction was stopped by adding $2.5 \mu \mathrm{l}$ of $0.20 \mathrm{M}$ EDTA. 
The digested product was immediately loaded on a $2 \%$ agarose gel and stained with SYBR Safe DNA Gel Stain (no. S33102; Invitrogen). Indel frequencies were estimated as previously described by calculating band intensities with ImageJ $(\mathrm{NIH})$ software and applying the following equation:

$$
\% \text { indels }=100 \times\left(1-\sqrt{\left(1-f_{\text {cut }}\right)}\right)
$$

where $f_{c u t}$ is the fraction cleaved, corresponding to the sum of intensities of the cleaved bands divided by the sum of total band intensities (Miller et al. 2007, Guschin et al. 2010, Reyon et al. 2012).

\section{Design of the ssODNs}

Single-stranded ODNs for the HDR were designed with 90-nt-long homology arms, including the specific change (as for the mutation of interest) in the core. Further changes with silent effect were incorporated in the template to prevent Cas 9 from reiterated cleavage after HDR, by means of the PAM sequence removal exchanging the last guanine of the sequence for a cytosine nucleotide to escape Cas9 recognition. Several in silico web tools (Human Splicing Finder (Desmet et al. 2009), NetGene2 (Brunak et al. 1991), and MaxEnt (Yeo and Burge 2004)) were used to test the possible splicing alterations due to this synonymous nucleotide change, resulting in zero predicted effects. The introduced variant also involved a new recognition site for the specific restriction enzyme MIsI (no. FD1214; Thermo Fisher Scientific), which in turn aided RFLP analysis for the edition testing. These long ssODNs were synthesized as Ultramer Oligonucleotides (Integrated DNA Technologies).

\section{RFLP analysis for edition testing}

gDNA extraction, target amplification, and purification were performed identically to the T7E1 assay. Digestion with corresponding restriction enzymes was fulfilled according to the manufacturer's instructions using $300 \mathrm{ng}$ purified product and was subsequently resolved on a 4\%-20\% high-resolution Tris-borate-EDTA (TBE) polyacrylamide gel (no. 4561093S; Bio-Rad, Hercules, CA, USA), following staining with SYBR Safe DNA Gel Stain. 


\section{Clonal amplicon Sanger sequencing}

A PCR product obtained from the target locus was cloned using a kit for sequencing purposes (TOPO TA Cloning Kit, no. K457502; Thermo Fisher Scientific) and introduced in $E$. coli.

Sanger sequencing was used to sequence 45 individual colonies to reveal the clonal genotype and thus the general indel frequency.

\section{HDFs cell culture and transfections}

Fibroblasts from WT controls and USH2 patients harboring the c.2299delG homozygotic mutation were isolated from skin biopsies and were maintained at $37^{\circ} \mathrm{C}$ and $5 \% \mathrm{CO}_{2}$ in Biowest DMEM high glucose without L-glutamine, without sodium pyruvate medium supplemented with 10\% FBS, 1\% Biowest PS solution 100x, and 1\% L-glutamine (no. X0550; Biowest).

Plasmid delivery trials were performed with several compounds: namely, Lipofectamine LTX (Thermo Fisher Scientific), Lipofectamine 3000 (Thermo Fisher Scientific), NanoJuice (Merck Millipore), polyethylenimine (Polysciences), Viromer (Lipocalyx), and Nucleofector 4D (Lonza), parallel to pmaxGFP transfection as a positive control. Neither the control GFP vector nor the CRISPR constructs showed significant results; the former achieved less than a $10 \%$ transfection efficiency with all the transfection products, except for Lipofectamine 3000, which showed no GFP-positive cells at all (data not shown). For that reason, the Cas9-sgRNA design was shifted from DNA usage to the RNP strategy, according to protocols from previous studies (Kim et al. 2014).

For the RNP complexes, $15 \mu \mathrm{g}$ purified Cas9 endonuclease (no. M0646T; New England Biolabs) was blended with $20 \mu \mathrm{g}$ IVT synthesized sgRNA (PNA Bio, CA, USA) by 10-min incubation at room temperature with 1x Cas9 Nuclease Reaction Buffer (New England Biolabs).

For HDF targeting, nucleofection assays were performed using program DT-130 on the 4D-Nucleofector System (Lonza, Basel, Switzerland). Premixed RNPs were added to $100 \mu \mathrm{l}$ P2 nucleofection solution where $2 \times 10^{5} \mathrm{HDF}$ had been previously resuspended for the nucleofection. The same concentration was used for the directed edition, together with $5 \mu \mathrm{l}$ sSODN-WT at $100 \mu \mathrm{M}$ (500 pmol) resuspended in the nucleofection solution. All experiments were assayed in duplicate. 


\section{Analysis of potential off-targets}

For the off-target analysis, two free-access bioinformatic prediction tools were used: Cas-OFFinder(Bae et al. 2014) from RGEN tools and the WTSI Genome Editing (WGE) tool from the Wellcome Trust Sanger Institute (Hodgkins et al. 2015). These were used to search for algorithms for highly similar sgRNA sequences throughout the genome. Algorithm parameters were set for a maximum of 2 mismatches, 2 bulges, or the combination of 1 mismatch and 1 bulge. The bulges appear when insertions or deletions are present in the DNA compared to the sgRNA sequence, forming a DNA bulge in the case of an insertion and an RNA bulge in the case of a deletion. The outcome of 45 potential off-targets was filtered by selecting all bulge-involving loci and those with mismatches with a higher impact, meaning they were located in genes. Two possible additional exonic off-targets were included despite the higher number of mismatches, in view of the risky repercussion. Putative off-target sites were ranked according to previous studies, where the quantity and PAM proximity of the dissimilarities have been proven to be a key factor for site recognition probability (Lin et al. 2014b, Anderson et al. 2015, Zhu et al. 2016).

\section{High-throughput sequence analysis}

Deep sequencing with a 500-cycle v2 Nano Reagent Kit (Illumina, San Diego, CA, USA) on a MiSeq platform (Illumina) was performed in order to precisely determine sgRNA-1 ontarget activity in HDFs, either NHEJ events or efficiently edited cells by HDR, and potential off-target issues. For this purpose, in silico predicted off-target loci and on-target regions from sgRNA-1 treated cell gDNA were amplified. Library preparation was fulfilled by a twostep PCR. The initial PCR was performed with specific locus primers with flanking TruSeq partial sequence adapters (Table 2). For the second PCR, primers with TruSeq adaptor sequences overlapping with PCR1 primers were used. The PCR products were pooled in equimolar amounts following the manufacturer's protocol. The sequencing yield exposed overall coverage $>50,000$ for each target.

For the data analysis, CRISPResso (Pinello et al. 2016) was used applying the following parameters: adaptor and 50-bp trimming, mean average quality 30 phred score, minimum (100) and maximum (400) paired end reads overlap, and ignoring substitutions and hiding mutations outside the NHEJ region. The on-target locus was studied for cleavage and edition quantification, considering all the reads with only the two introduced variants (c.2299insG and c.2292G >C) as edited sequences. The CRISPR system is supposed to cleave virtually 3-4 bp upstream of any preceding PAM sequence (Swarts et al. 2012), yet the 
previous clonal amplicon Sanger sequencing on HEK293 cells showed evidence repair scars that appeared displaced some bases from the canonic cutting spot (Figure 2B). Therefore, a 10-bp window for the survey was established, straying from the canonical cleavage point. A parallel custom data analysis was performed and the results were equivalent to the outcome from the CRISPResso tool. The number of cleaved sequences was calculated by the sum of reads with indels enclosed in this frame and the number of edited cells that had been cleaved in the first instance.

Table 2. Locus-specific primer sequences for MiSeq deep sequencing

\begin{tabular}{|c|c|c|}
\hline Locus name & 5'-3' Forward primer ${ }^{a}$ & $5^{\prime}-3^{\prime}$ Reverse primer ${ }^{b}$ \\
\hline USH2A (on-target) & AGGGCTTAGGTGTGATCATTGC & TAGCATTACAGACAGTCCCAGG \\
\hline STK3 & TCATGCTCAGTGCACTGTAC & CTCTGTTCACAGATGATATG \\
\hline FHIT & СTTCTCTTGACTAGGAAAGG & CCACCATTTAAAAGCCTCCC \\
\hline TENM2 & TTGCACTTCCCAGATGAGGTG & GGATATGAACTTTCTCCAACAC \\
\hline ROR1 & CAGAATTCCGATTTCTTGTCTC & GCCCACCATTATAACATTTCAG \\
\hline SPG20 & GCAAAGATATAATGGACATGG & TGACAGATAATCTTCTGATCC \\
\hline TBR1 & TGCTGGTGCCCTTTTCTTTAGG & TGTCTCAGGCGCTCAATGTAAG \\
\hline DMD & AGAGGAACACACCAAATCTGG & AGCCACGTATTTGTCTTTCC \\
\hline RGS7BP & CAGTGTTCTCAATGTCTGTGG & TGACTCAAAGCATAGCCAACC \\
\hline EHD1 & CCTCTTAGTGTGTGCTTTGG & AGTGGATGCTTCAGTTGCTG \\
\hline KLHL15 & ACATAAATTGCAGGACATGGC & AGGATTCTGTTCCTCCATCC \\
\hline intergenic & GTGCATACAAGAGTGGCTTG & ACCCTTCTGGATGAAAGCTG \\
\hline TIM22 & TGGTCTTCTCGGCAGAGATC & AAGCTCCGCTGCAGTACAGC \\
\hline HNRNPUL2 & СTCCATTTCTCTTCCAGTGG & TGCGACACATCTTAGCTCG \\
\hline C5orf66 & AGTCTCTGAGAGGCTTTGGATG & ACAGCTTGGGTGTTCAGAAACC \\
\hline RBFOX1 & CTAAGTGCACTACATGGTCACC & ACTGCCAAGAAGAGCTTCTTCC \\
\hline LOC730100 & AAAGATTGACCTCAGAGCC & GTAAATATGCTGCAGAGAC \\
\hline IGKV1-33 & TACAACTGCCAATCATGTGGTC & AGAAACCCTATGCCTTCTCTGG \\
\hline IGKV1D-33 & ATAGAGAAGGTACAACTGCC & CAGAAACCCTATGCCTTCTC \\
\hline BAZ2B & TGCTAAGGTAATCAAAGTG & CTTTGAGAGAGTTTCACTC \\
\hline TANC2 & TGTGAGAATCCTCCACTTTGG & ATGAGGTAGCAGTGAACTGTG \\
\hline SLX4IP & GGAAATTCTCATATGGCTGG & GCTATTCCCAACAGTTTGTG \\
\hline \multicolumn{3}{|c|}{$\begin{array}{l}\text { ' Forward primers have appended the last 5'-3' } 34 \text { bases of the TruSeq adaptor sequence: } \\
\text { TACACTCTTTCCCTACACGACGCTCTTCCGATCT } \\
\text { ' } \text { Reverse primers have appended the first 3'-5' } 34 \text { bases of the TruSeq adaptor sequence: } \\
\text { GTGACTGGAGTTCAGACGTGTGCTCTTCCGATCT }\end{array}$} \\
\hline
\end{tabular}




\section{Author Contributions}

Conceptualization, C.F.-G. and E.A.; Methodology, C.F.-G., G.G.-G., and E.A.; Investigation, C.F.-G., G.G.-G., E.G.-R., and M.D.S.; Writing - Original Draft, C.F.-G.; Writing - Review \& Editing, G.G.-G, T.J., R.P.V.-M., J.M.M., and E.A.; Resources, R.V.P.-M., C.A., and E.A.; Supervision, T.J., R.P.V.M., J.M.M., and E.A.; Funding Acquisition, J.M.M. and E.A.

\section{Acknowledgements}

We thank the patients involved in this study and the patient associations Retina CV and FARPE. We thank the CIBERER biobank (Valencia, Spain) for sharing the skin biopsy-derived HDFs from one of the control patients, and we also thank dermatologist Montserrat Évole for the medical procedure. We also thank Paul E. Gutteridge for the grammatical revision of the English. We acknowledge Sheila Zúñiga at the Medical Research Institute Hospital La Fe and Galo A. Goig from the Genomics and Health Unit (Fundación para el Fomento de la Investigación Sanitaria y Biomédica de la Comunitat Valenciana [FISABIO]) for help with the bioinformatics analysis. We are grateful to Dr. Juan Bueren (Centro de Investigaciones Energéticas, Medioambientales y Tecnológicas [CIEMAT]) and Dr. Lluís Montoliu (Centro Nacional de Biotecnología-Centro Superior de Investigaciones Científicas [CNB-CSIC]) for their technical support. This work was financially supported by the Institute of Health Carlos III and FEDER funds (ISCIII; grants PI13/00638, PI16/00425, PI16/00539, and PIE13/00046), Fundación ONCE (grant 2015/0398), XVIII Fundaluce-FARPE, and "Telemaratón: Todos Somos Raros, Todos Somos Únicos" (grant IP58). C.F.-G. is a recipient of a fellowship (grant IFI14/00021) from the ISCIII. R.P.V.-M. is a Miguel Servet researcher (grant CP11/00090 funded by ISCIII, Madrid, Spain). The funds from the ISCIII are partially supported by the European Regional Development Fund. R.-P.V.M. is also a Marie Curie fellow (grant CIG322034 from the European Commission). 



\section{CHAPTER II}

\section{High-throughput sequencing for the molecular diagnosis of Usher syndrome reveals 42 novel mutations and consolidates CEP250 as Usher-like disease causative}

Carla Fuster-García ${ }^{1}$, Gema García-García ${ }^{1,2}$, Teresa Jaijo ${ }^{1,2,3}$, Neus Fornés ${ }^{1}$, Carmen Ayuso ${ }^{2,4}$, Miguel Fernández-Burriel ${ }^{5}$, Ana Sánchez-De la Morena ${ }^{6}$, Elena Aller ${ }^{1,2,3}$, and José M. Millán ${ }^{1,2}$.

\footnotetext{
${ }^{1}$ Grupo de Investigación en Biomedicina Molecular, Celular y Genómica, Instituto de Investigación Sanitaria La Fe (IIS La Fe), Valencia, Spain. ${ }^{2}$ CIBER de Enfermedades Raras (CIBERER), Madrid, Spain. ${ }^{3}$ Unidad de Genética y Diagnóstico Prenatal, Hospital Universitario y Politécnico La Fe, Valencia, Spain. ${ }^{4}$ Servicio de Genética, Fundación Jiménez Díaz, University Hospital, Instituto de Investigación Sanitaria Fundación Jiménez Díaz IIS-FJD, UAM, Madrid, Spain. 5Unidad de Genética, Hospital de Mérida, Mérida, Badajoz, Spain. 6Servicio de Oftalmología, Hospital de Mérida, Mérida, Badajoz, Spain. Elena Aller and José M. Millán contributed equally.
}

Scientific Reports, Volume 8, Article number: 17113 (2018) doi: 10.1038/s41598-018-35085-0. (Adapted to meet the format of the present dissertation) 


\section{Abstract}

Usher syndrome is a rare disorder causing retinitis pigmentosa, together with sensorineural hearing loss. Due to the phenotypic and genetic heterogeneity of this disease, the best method to screen the causative mutations is by high-throughput sequencing. In this study, we tested a semiconductor chip based sequencing approach with 77 unrelated patients, as a molecular diagnosis routine. In addition, Multiplex Ligation-dependent Probe Amplification and microarray-based Comparative Genomic Hybridization techniques were applied to detect large rearrangements, and minigene assays were performed to confirm the mRNA processing aberrations caused by splice-site mutations. The designed panel included all the USH causative genes (MYO7A, USH1C, CDH23, PCDH15, USH1G, CIB2, USH2A, ADGRV1, WHRN and CLRN1) as well as four uncertainly associated genes (HARS, PDZD7, CEP250 and C20rf71). The outcome showed an overall mutation detection ratio of $82.8 \%$ and allowed the identification of 42 novel putatively pathogenic mutations. Furthermore, we detected two novel nonsense mutations in CEP250 in a patient with a disease mimicking Usher syndrome that associates visual impairment due to cone-rod dystrophy and progressive hearing loss. Therefore, this approach proved reliable results for the molecular diagnosis of the disease and also allowed the consolidation of the CEP250 gene as disease causative for an Usher-like phenotype. 


\section{Introduction}

Usher syndrome (USH) is a rare autosomal recessive disease that associates retinitis pigmentosa (RP), sensorineural hearing loss ( $\mathrm{SNHL}$ ) and, in some cases, vestibular dysfunction. It is the most common form of hereditary disease combining hearing and vision impairment, with a prevalence ranging from 3 to 6.2 per 100,000 (Boughman et al. 1983, Cohen et al. 2007). Three types of USH are distinguished depending on the severity and progression of the pathology: Type 1 (USH1) is typically characterized by a severe-profound congenital hearing loss, onset of RP usually within the first decade of life, and vestibular dysfunction. Type 2 (USH2) patients present with a moderate-severe congenital hearing impairment, a pubertal onset of RP and normal vestibular function. Type 3 (USH3) is defined by progressive hearing loss starting after post-lingual phase and an age-variable onset of RP, whereas the vestibular dysfunction is variable (Millán et al. 2011). Despite the three major divisions of the disorder, some patients display a clinical profile not matching any of these categories, being classified as atypical USH.

As well as clinically, USH is genetically heterogeneous. To date, 13 genes have been associated with the disease and these do not explain all the reported cases, suggesting other still unknown genes may be responsible for the disorder (Mathur and Yang 2015).

USH1 is commonly caused by mutations in six genes: MYO7A, USH1C, CDH23, PCDH15, USH1G and CIB2. On the other hand, USH2A, ADGRV1 and WHRN are the three genes usually responsible for $\mathrm{USH} 2$, whilst the $C L R N 1$ gene is the only one currently associated to USH3 cases.

In addition, other genes have been related to the disease. The PDZD7gene has been reported to behave as a modifier of retinal disease with USH2A and a contributor to digenic inheritance with ADGRVI (Ebermann et al. 2010). Recently, HARS was proposed as a novel causative gene of USH3, based on a mutation found in two patients (Puffenberger et al. 2012) and CEP250 has been reported as responsible for an atypical Usher syndrome with SNHL and a relatively mild RP(Khateb et al. 2014).

Most of the USH-causing mutations are private and most of the involved genes are of a large size. These issues can be overcome with the use of high-throughput sequencing (HTS) tools, which enable a rapid, feasible method for the genetic diagnosis of the disease, and they are being increasingly employed (Aparisi et al. 2014, Jiang et al. 2015, Eandi et al. 2017, Neuhaus et al. 2017, Kooshavar et al. 2018). The main objective of the present study is the molecular diagnosis of a large cohort of USH patients by means of a HTS screening. Thus, 
we developed a custom targeted exome design, including the ten disease causative genes and four additional candidates, for its use in lon Torrent platforms.

\section{Methods}

Patients

A cohort of 77 USH patients was selected for this study. The probands were classified into the different USH subtypes according to their clinical records. The data (when feasible) consisted of the patient's ophthalmological studies, including best-corrected visual acuity measurements (BCVA), fundus ophthalmoscopy, visual field examination and electrophysiological examination; and audiological tests (Kumar et al. 1984, Möller et al. 1989, Seeliger et al. 1999). Hearing loss severity was established as mild (between $>25$ and $\leq 40 \mathrm{~dB}$ ), moderate (between $>40$ and $\leq 70 \mathrm{~dB}$ ) or severe/profound ( $>70 \mathrm{~dB}$ ). Patients presenting a bilateral severe congenital hearing loss ( $>70 \mathrm{~dB}$ ), early RP onset and altered vestibular function were diagnosed as USH1. Patients suffering from bilateral congenital moderate-severe hearing loss $(40-70 \mathrm{~dB})$ and adolescent-to-adult onset of RP were categorized as USH2. If the patients displayed progressive hearing loss, with or without vestibular dysfunction, and late onset RP, were recognized as USH3. Patients with a profile not quite matching any of these three categories were diagnosed as atypical USH cases. When the clinical data was insufficient, the type was stated as general USH. For case RP1973, further ophthalmological examinations were performed, which included measurements of fundus autofluorescence (FAF), optical coherence tomography (OCT) (acquired with a Heidelberg Spectralis OCT Bluepeak) and visual fields 30-2 and 120-2 strategies by the Humphrey Visual Field Analyzer. Full-field electroretinography was performed according to the International Society for Clinical Electrophysiology of Vision Standards (McCulloch et al. 2015).

From all the patients included, 19 were assigned to a test group in order to evaluate the sequencing platform performance. Eight cases out of these already had a complete molecular diagnosis (at least two USH causative mutations) and 11 where partially solved with only one previously known disease causing mutation. The test group comprised a total of 4 Copy Number Variations (CNVs) and 22 point mutations, represented by variants of different nature (Table 1). Finally, a cohort of 58 previously unscreened USH patients of Spanish origin were recruited for this study in order to determine their genetic diagnosis. Among these to be characterized, 15 were USH1, 31 USH2, and 12 undetermined USH. 
Segregation analysis was performed by conventional Sanger sequencing when DNA samples of family members were available.

\section{Ethics Statement}

This study was approved by the Hospital La Fe Ethics Committee and authorizations from all the patients and the participating relatives were obtained by signing an informed consent form. All research was performed in accordance with the relevant guidelines and regulations.

\section{Samples}

Genomic DNA (gDNA) from the probands was obtained and purified using standard procedures. The concentration of the resulting DNA samples was determined with Nanodrop and Qubit fluorometer (Thermo Fisher Scientific).

\section{Targeted USH exome sequencing design}

A customized AmpliSeq panel was designed using Ion AmpliSeq Designer tool from Thermo Fisher Scientific (www.ampliseq.com) to generate the targeted library. The designed targeted exome (Table 2) included all exons contemplated in all isoforms of 14 genes: the 10 USH causative genes (MYOTA, USH1C, CDH23, PCDH15, USH1G, CIB2, USH2A, ADGRV1, WHRN and $(L R N 1$ ), the additional locus comprising the c.7595-2144A $>\mathrm{G}$ intronic mutation in USH2A (Vaché et al. 2012), and 4 USH associated genes (HARS, PDZD7, CEP250 and C2orf71). 


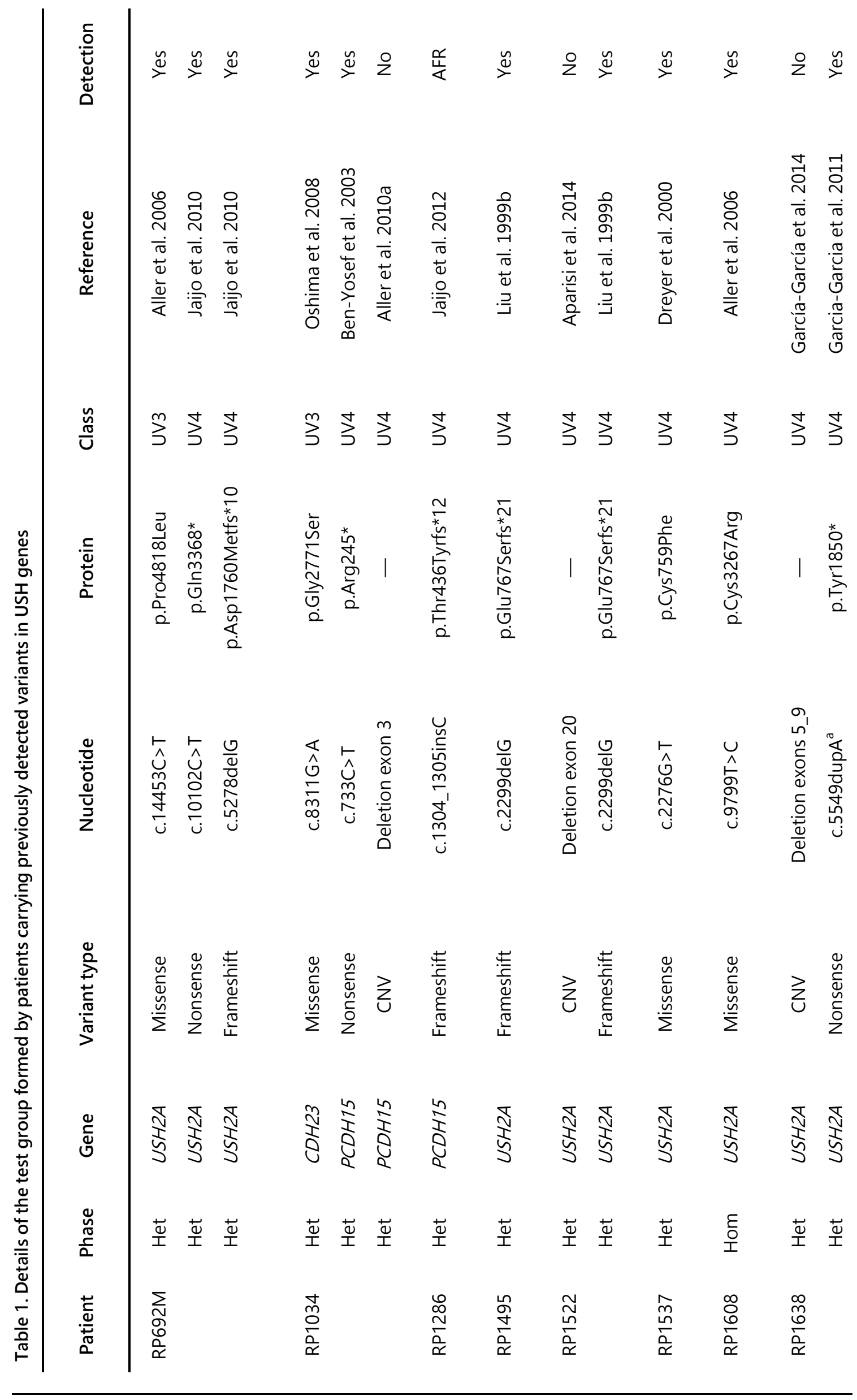




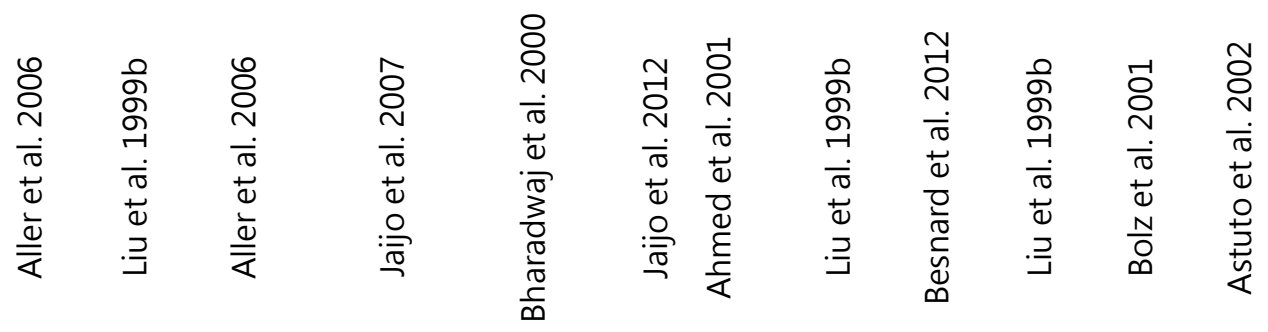

$3^{m} 3^{*} 3^{m} 3^{+} 3^{+} 3^{+} 3^{+} 3^{+}$

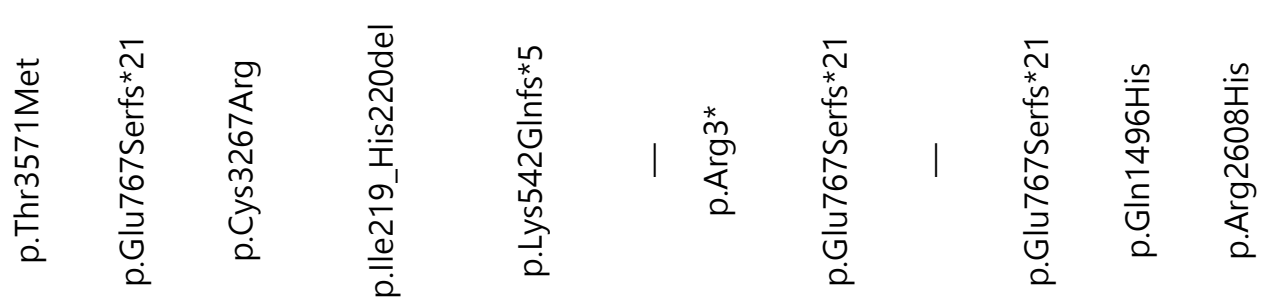

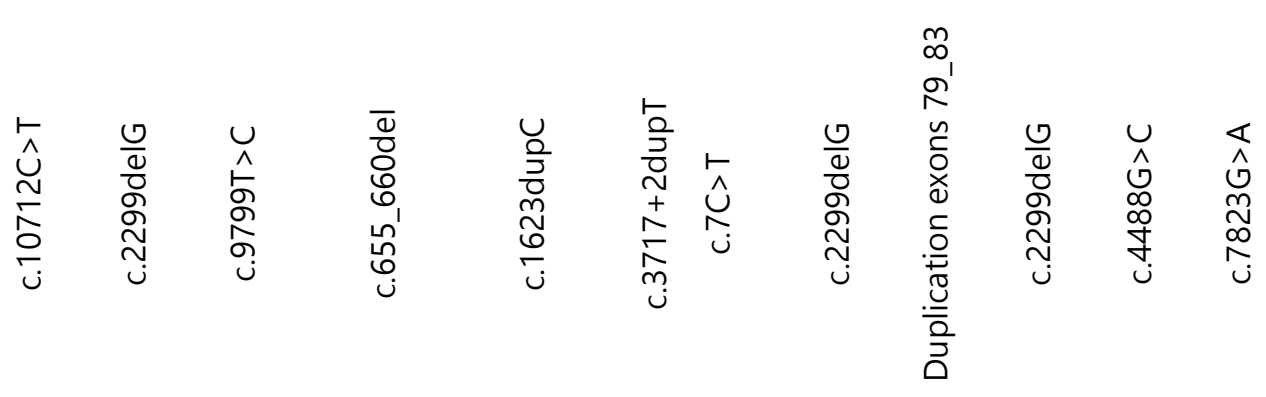

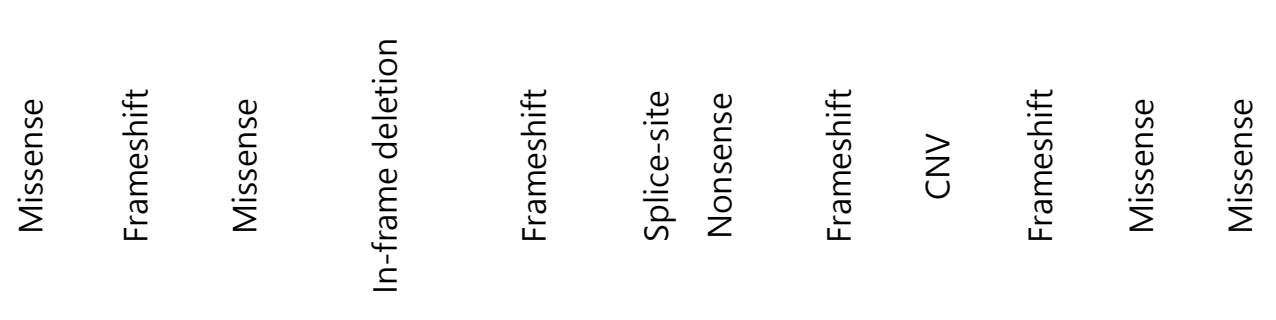

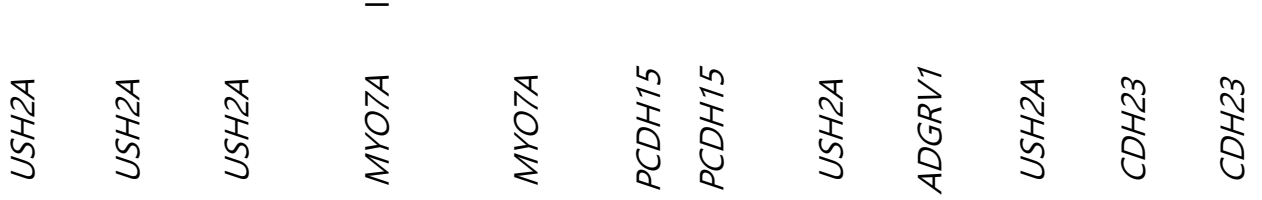

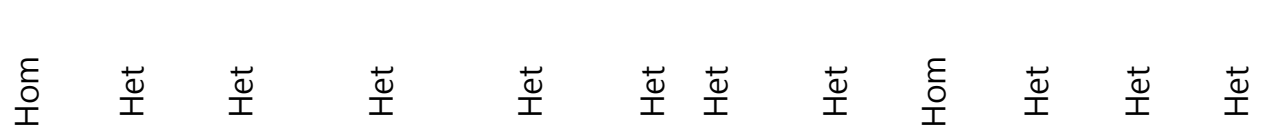

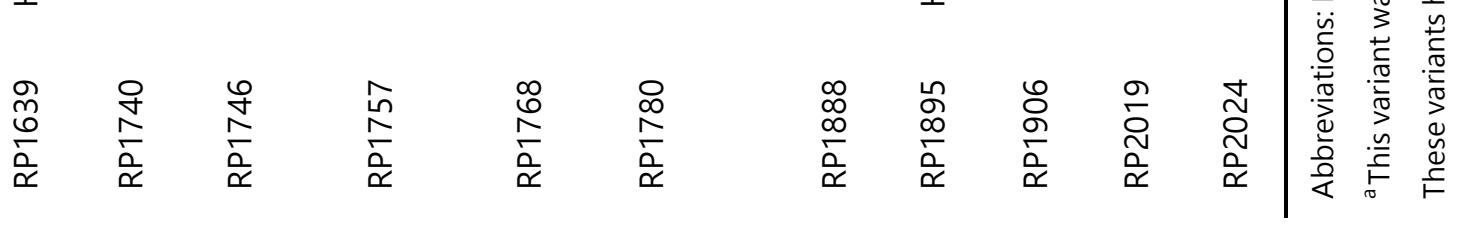




\section{Sequence enrichment and HTS}

The amplification of the targets was performed according to the Ion AmpliSeq Library Kit 2.0 protocol (Thermo Fisher Scientific) for lon Torrent sequencing. The sequencing was carried out with a theoretical minimum coverage of 500x either on the PGM (Ion 318 chip, 500 flows) or Proton system (Ion PI chip, 520 flows).

\section{Variant filtering and analysis}

The resulting sequencing data were analyzed with Ion Reporter Software tool (https://ionreporter.thermofisher.com) in regard to the human assembly GRCh37/hg19. The annotated variants were filtered according to a Minor Allele Frequency (MAF) value $\leq 0.01$, the frequency of the variants was explored in the Exome Aggregation Consortium (ExAC) database, their annotation in the dbSNP (www.ncbi.nlm.nih.gov/SNP/), their description in the Usher syndrome mutation database (https://grenada.lumc.nl/LOVD2/Usher_montpellier/) and the mutation type.

In order to determine the pathogenicity of novel missense or splice-site mutations, the variants were analyzed using several in silico prediction tools according to the nature of the mutation. Aminoacid change effects were examinated using the SIFT (Kumar et al. 2009), PolyPhen-2 (Adzhubei et al. 2010) and PROVEAN (Choi and Chan 2015) programs and the additional tools ATGpr (Salamov et al. 1998), NetStart(Pedersen and Nielsen 1997) and TIS Miner (Liu et al. 2005) were applied when concerning translation start loss variants. Putative variants affecting the splicing pattern were investigated with the Human Splicing Finder 3.1 (Desmet et al. 2009), MaxEnt (Yeo and Burge 2004) and NNSplice (Reese et al. 1997) algorithms.

All the putative pathogenic variants were validated through conventional Sanger sequencing. All the poorly or null covered regions were screened by conventional Sanger for all the cases with only one or none putative disease causing mutations detected through HTS. Additionally, the same patients were screened by Sanger sequencing for recently identified deep intronic mutations that were published after the start of this study and could therefore not be included in the panel design: four in USH2A, namely c.14134-3169A>G (Baux et al. 2017), c.5573-843A>G, c.8845+628C>T, c.9959-4159A>G (Liquori et al. 2016); and variant c.254-649T> G of CLRN1 (Khan et al. 2017). 


\section{Copy Number Variation analysis}

The screening for large rearrangements was performed in all patients where either none or only one mutation was detected with the panel, using either multiplex ligationdependent probe amplification (MLPA) or a custom microarray-based Comparative Genomic Hybridisation (aCGH).

The MLPA technique (MRC-Holland) allows the identification of large rearrangements for the USH2A (probemixes P361 and P362) and PCDH15 (probemix P292) genes.

In order to screen possible CNVs in the remaining genes, aCGH was designed covering all the genes included in this study. The resulting custom $60 \mathrm{~K}$ microarray (Agilent Technologies, AMADID-082310) contained 62976 probes. Three DNA samples with known CNVs from the test group (RP1895, RP1522, RP1034) were used as positive controls in the first batch of the analysis, in order to validate the custom design of the array. The gDNAs were prepared according to the manufacturer's protocol, as described before (Aller et al. 2010a).

\section{Splicing Effect Analysis by Minigenes}

Minigene assay was performed for all novel intronic mutations found in this study in order to confirm the splicing alterations, adopting a procedure previously described (Aparisi et al. 2013) and using HEK293 cells. All experiments were performed in duplicate.

\section{Extended exome screening}

Whole exome sequencing (WES) using SureSelect Human All Exon V6 kit (Agilent Technologies) for Illumina platform was performed for sample RP1973 to discard mutations in other genes, in view of the results obtained for this case. 


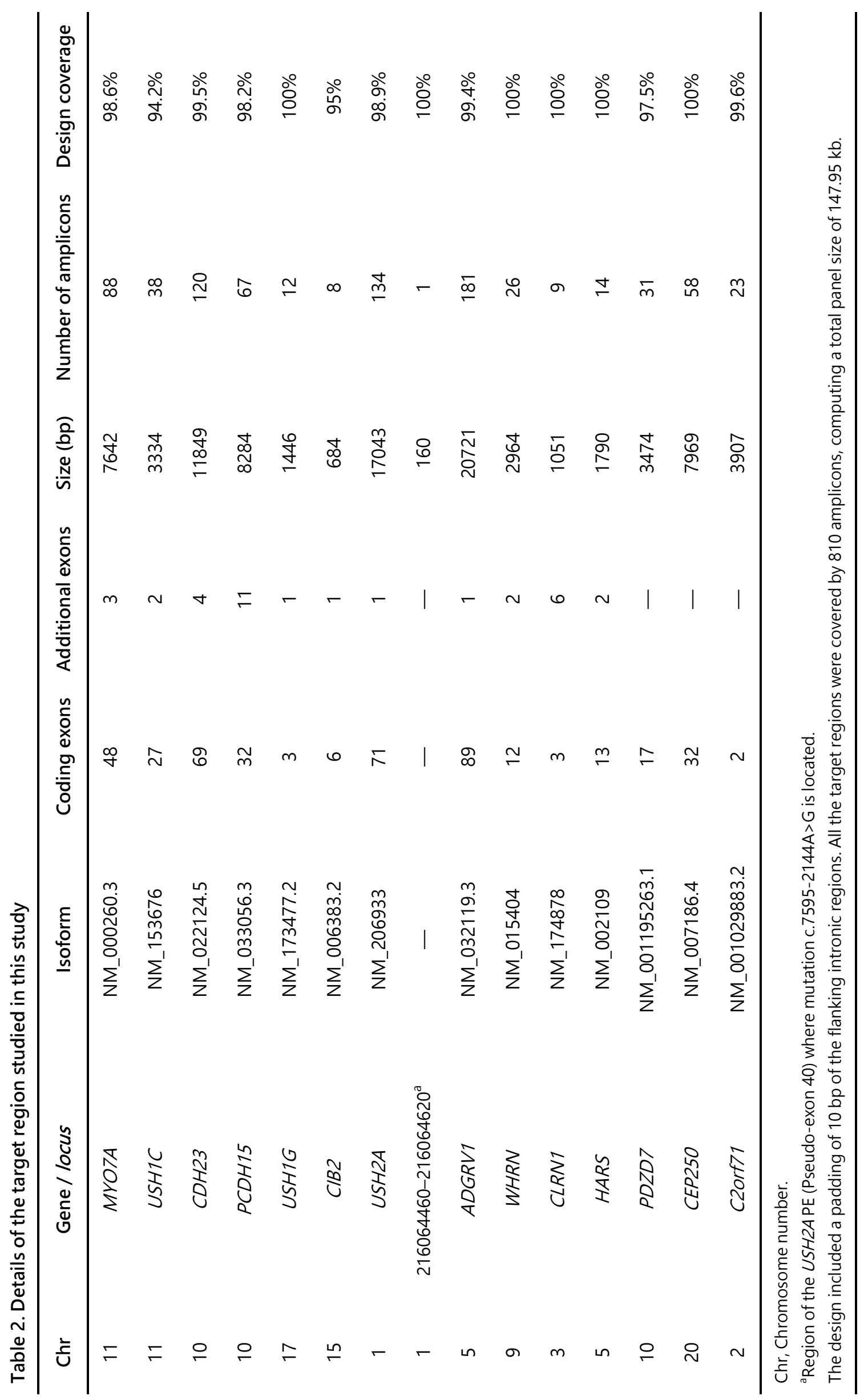




\section{Results}

\section{Test group}

The sequencing results allowed us to identify 20 of the 22 point mutations from the positive controls, while none of the CNVs was detected. When forcing a general parameters relaxation, the two previously undetected changes consisting of frameshift duplications were then recognized. These results and detailed information are summarized in Table 1.

In this study, the second disease causing mutation was detected in 7 out of the 11 patients included in the test group in whom only one of the pathological alleles was previously registered and, therefore, their genetic diagnosis was fulfilled (Table 3). These included 6 novel mutations: two nonsense mutations, two CNVs, 1 frameshift and 1 splicesite mutation.

\section{Cohort of previously unscreened USH patients}

We identified both pathogenic variants in 45 out of the 58 the analyzed cases and in 6 patients only one mutation was detected. No likely pathogenic mutations were found in other 7 probands.

This work allowed to detect mutations of different nature, from which 42 were novel variants (Table 3). Among these novel changes, we were able to detect 8 missense, 14 nonsense, 11 frameshift, 4 splice-site, 1 start loss variant and 4 large rearrangements (Tables 3 and 4). Regarding all the detected mutations, USH2A shows the highest prevalence, accounting for $48 \%$ of the causative variants (Figure 1 ).

Custom aCGH unveiled three CNVs in the ADGRV1 gene: one large heterozygous duplication involving exons 79-83 in patient RP580, the heterozygous deletion of exon 85 in patient RP1936, and one large homozygous deletion comprising exons 28-33 in proband RP2011. The latter was also suspected beforehand by the null coverage of that region on the HTS sequencing results. 


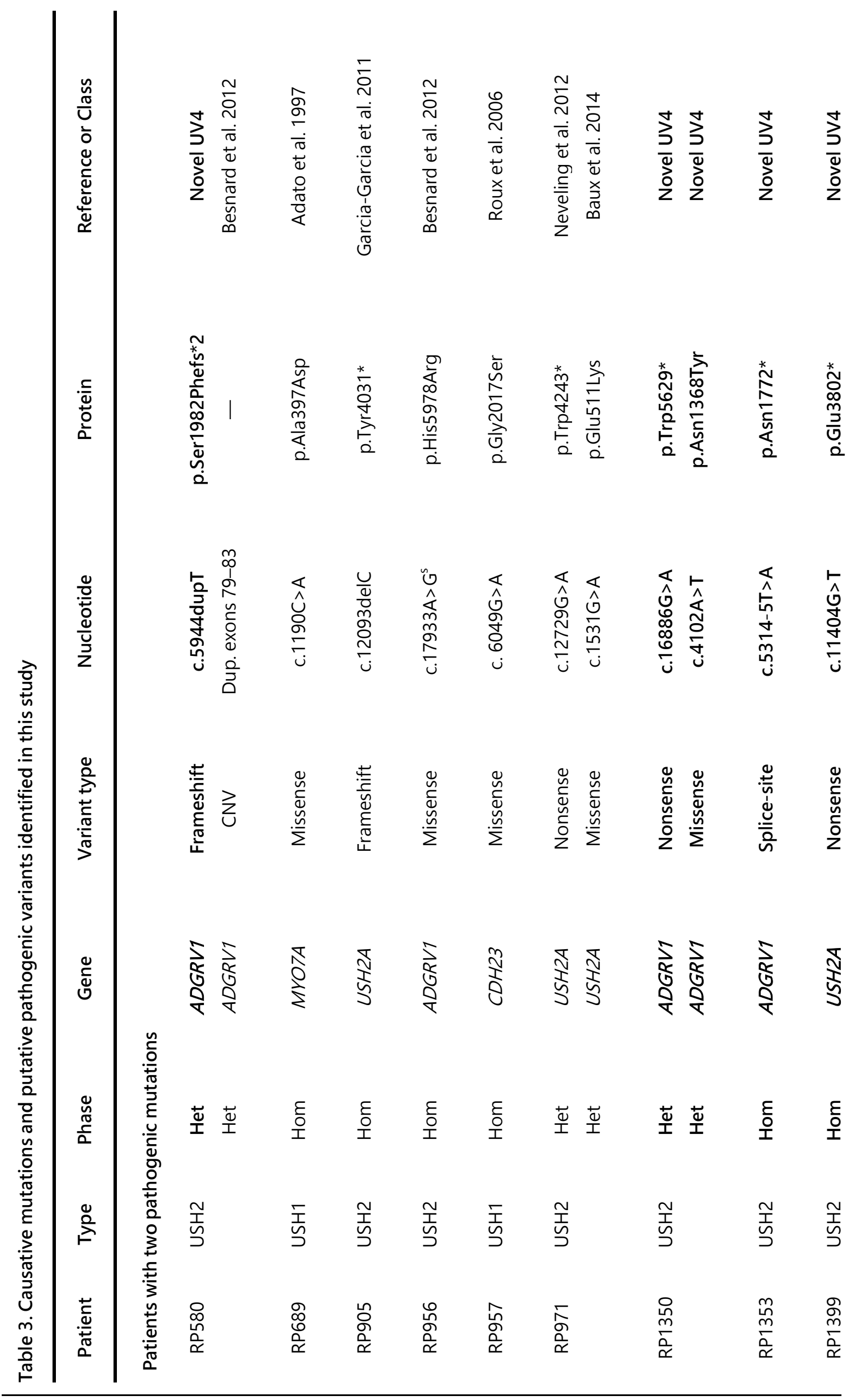




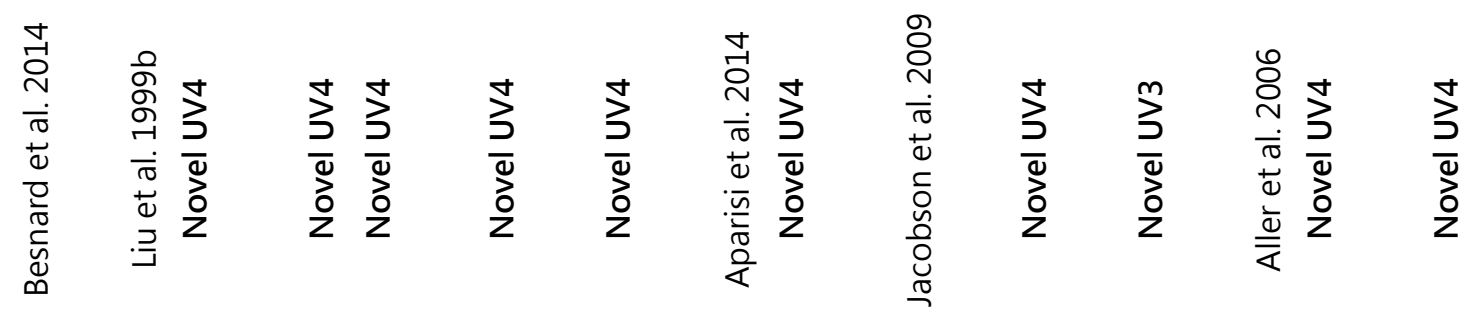

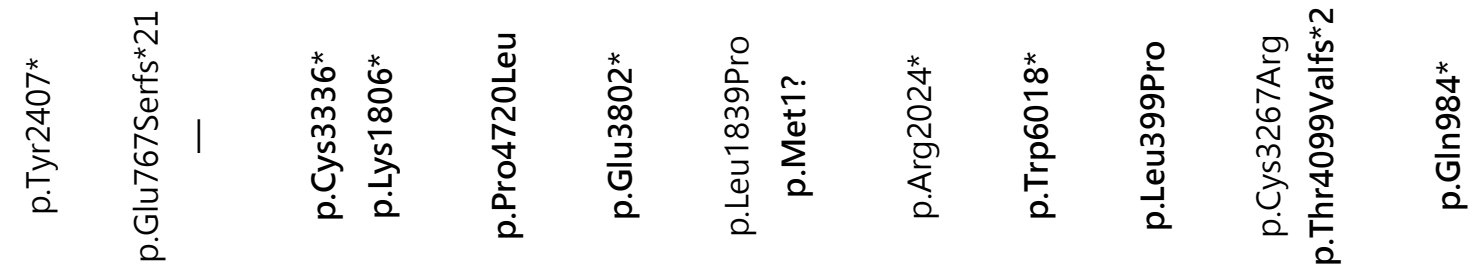

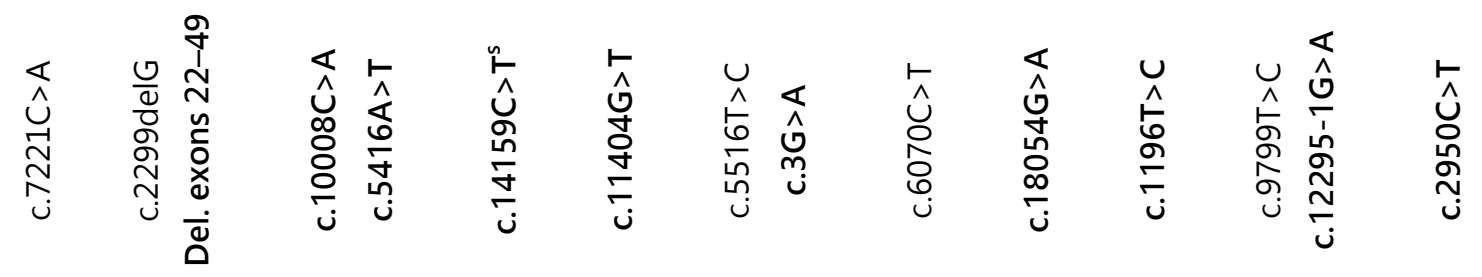

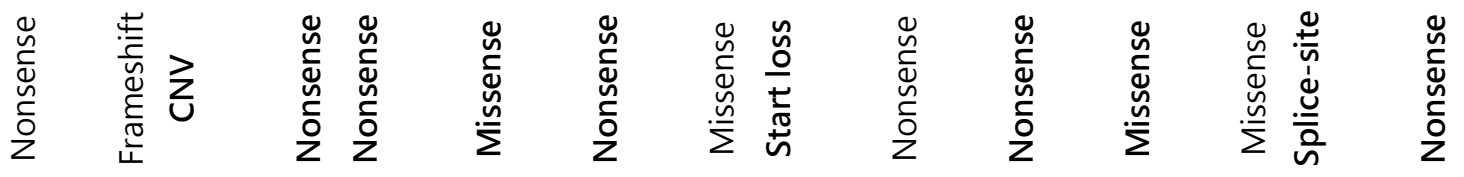

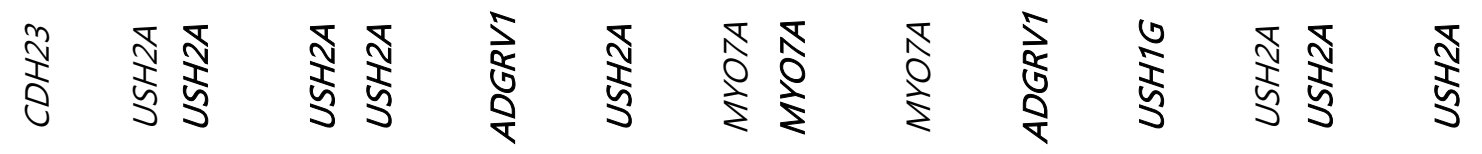

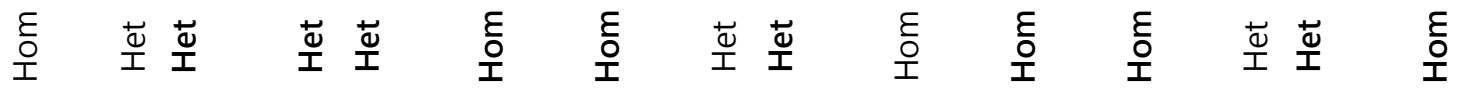

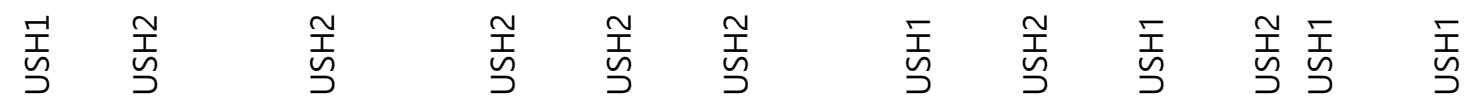

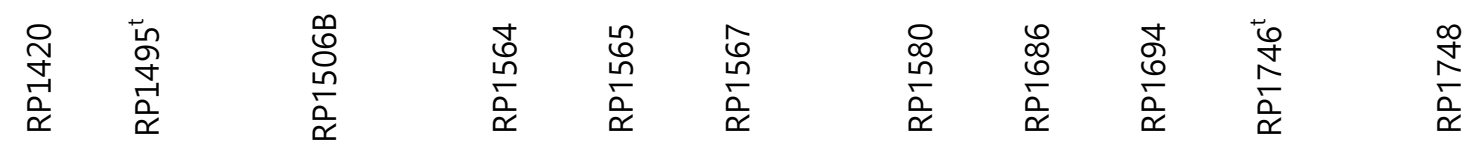




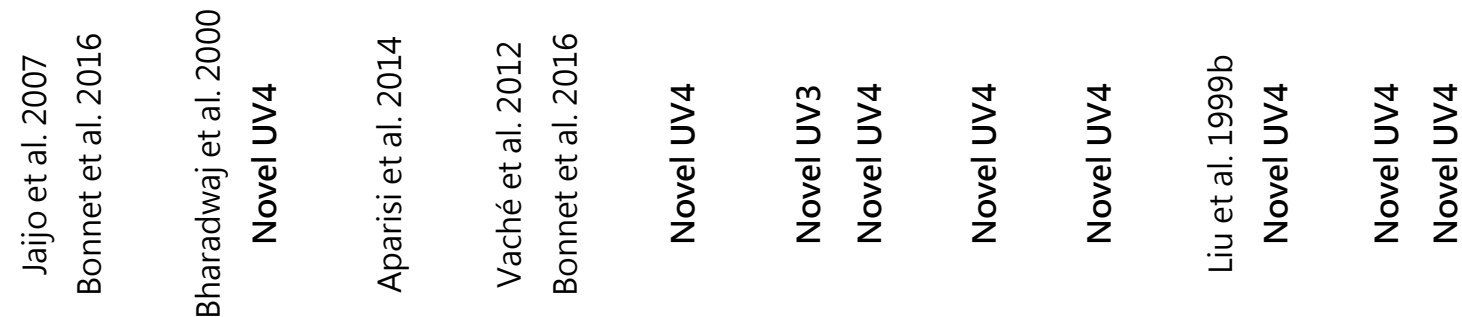

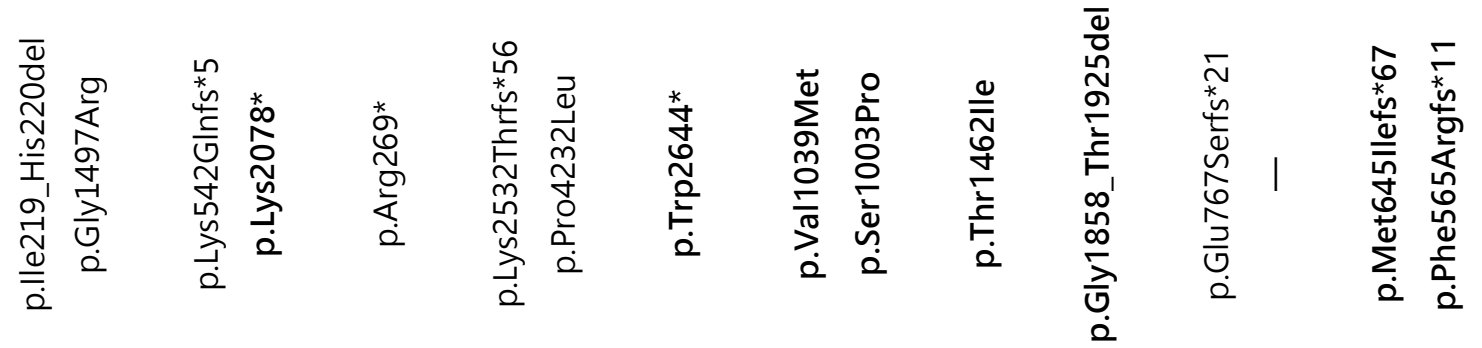

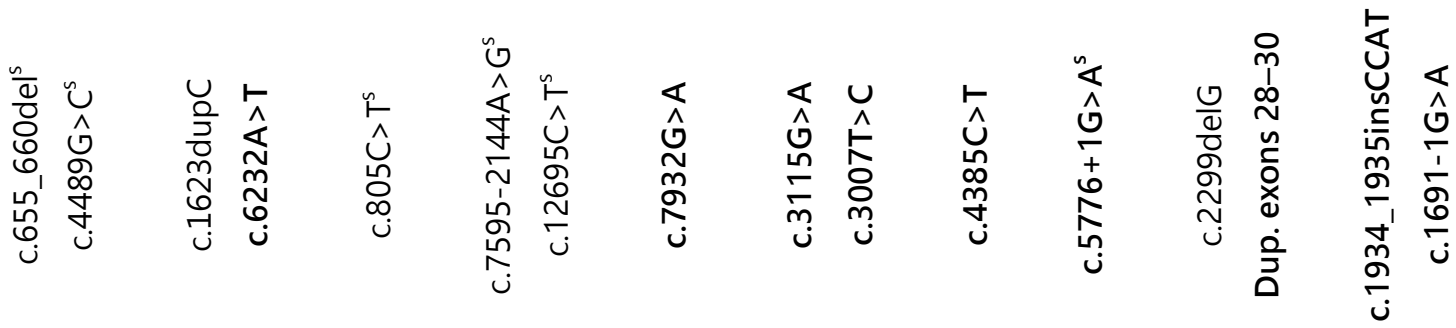

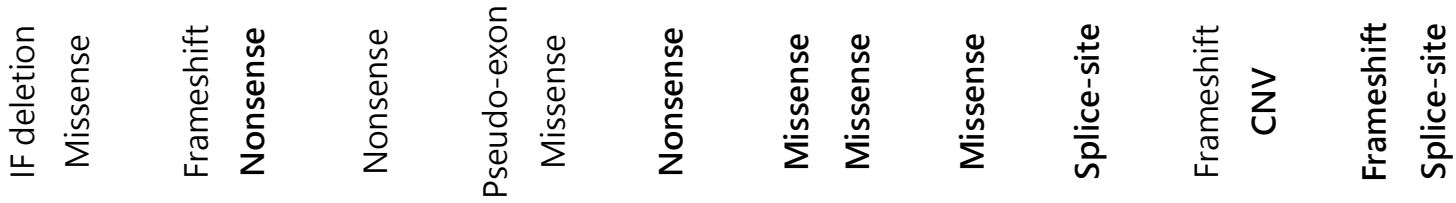

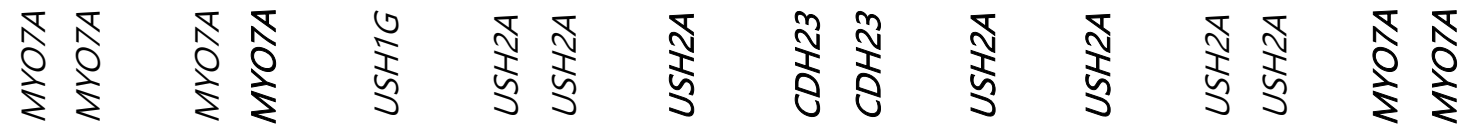

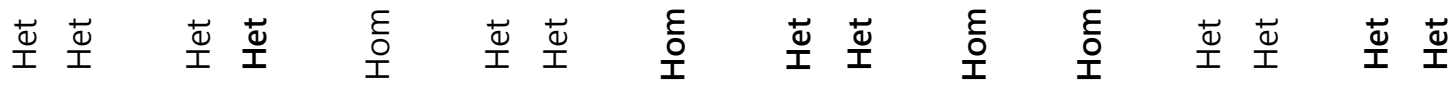

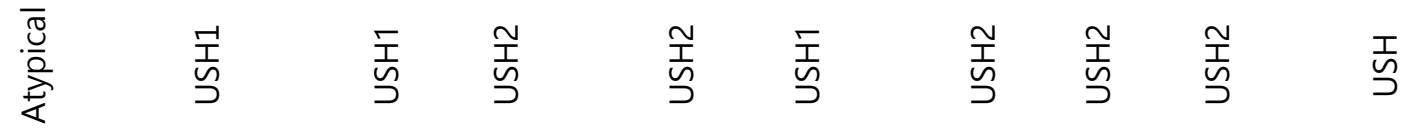

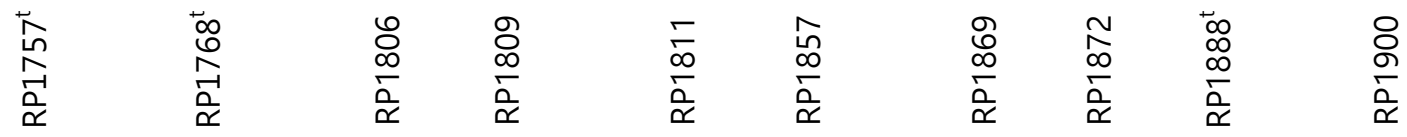




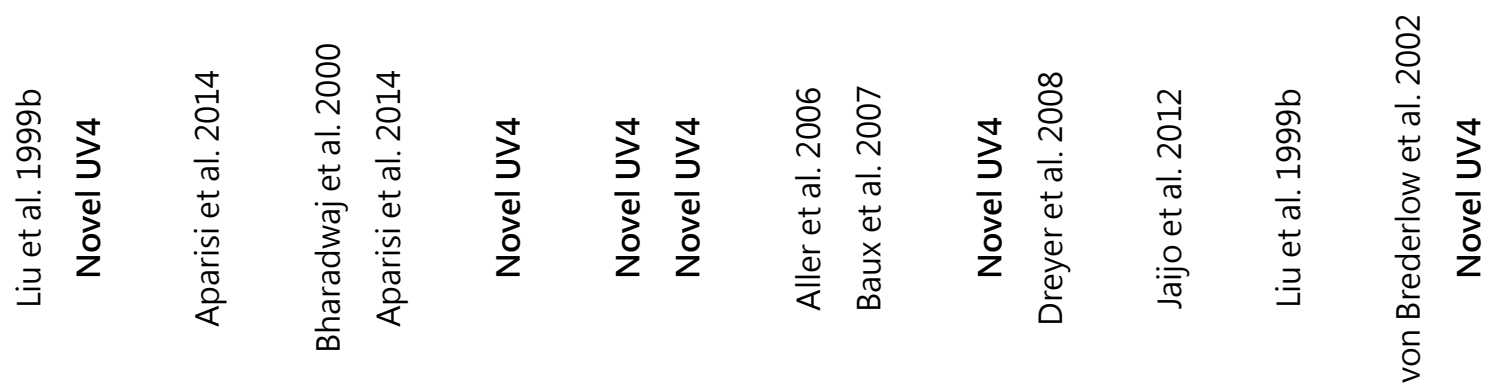

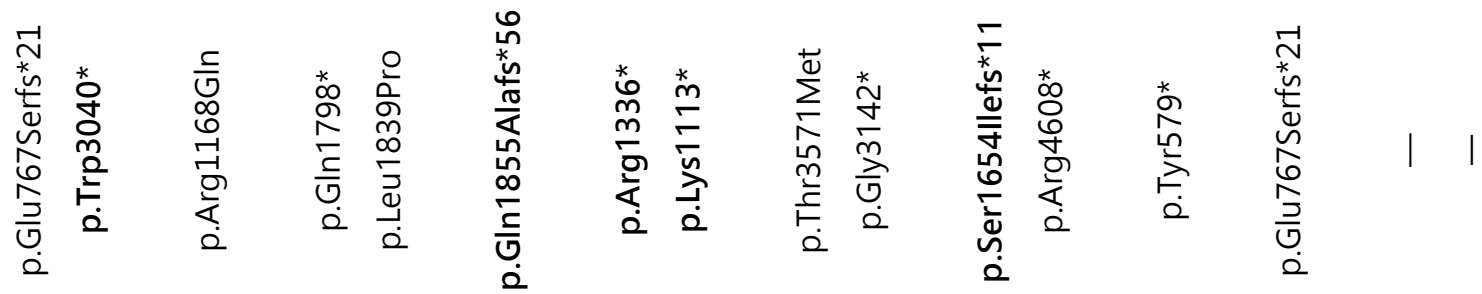

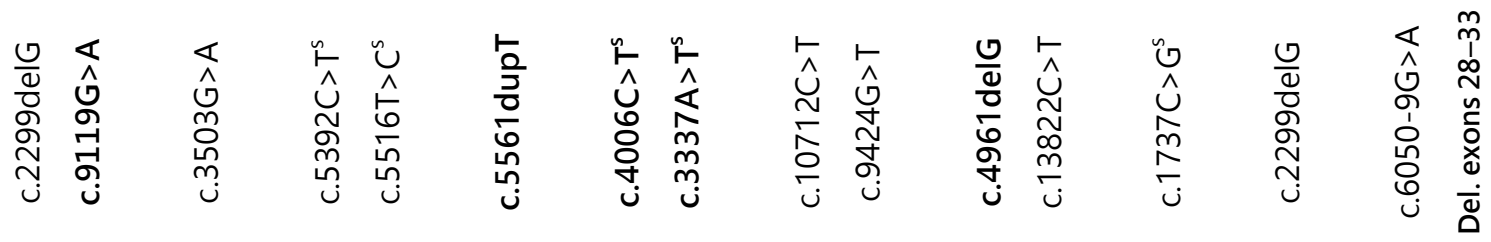

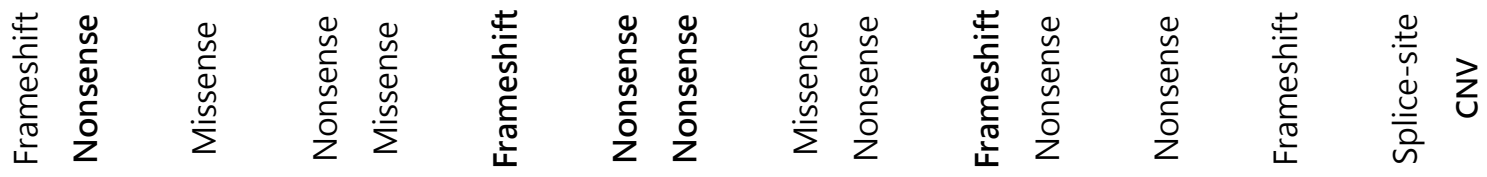

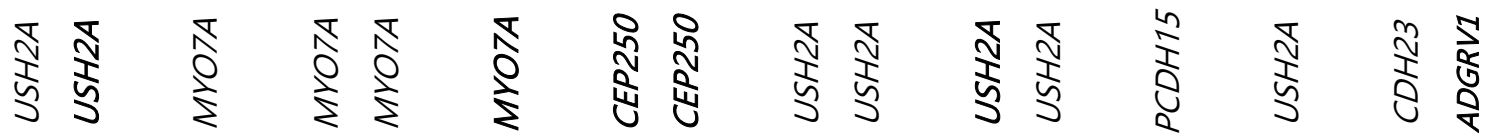

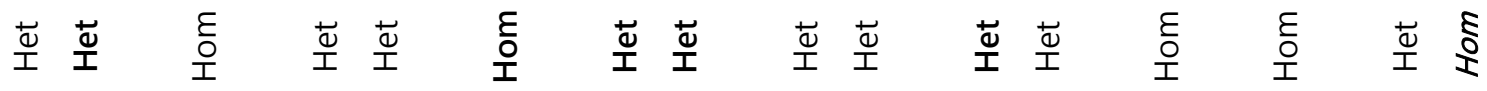

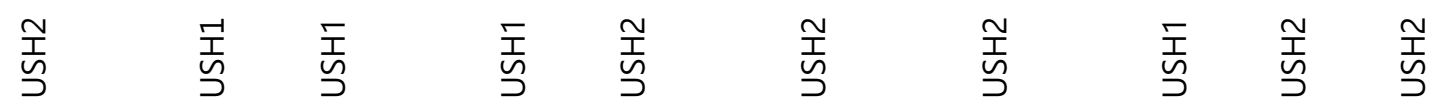

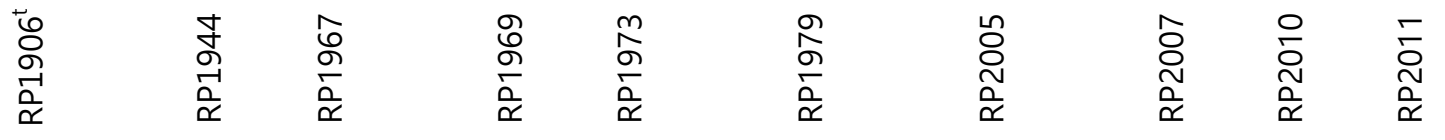




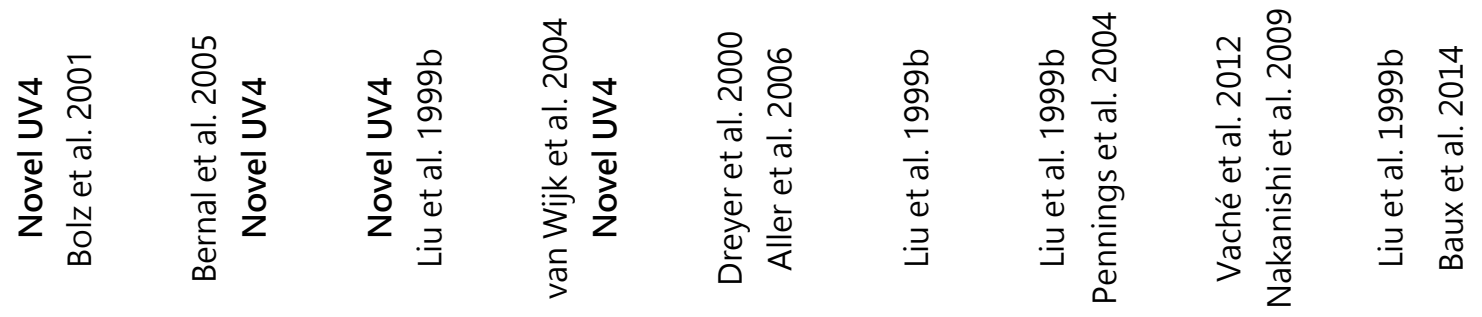

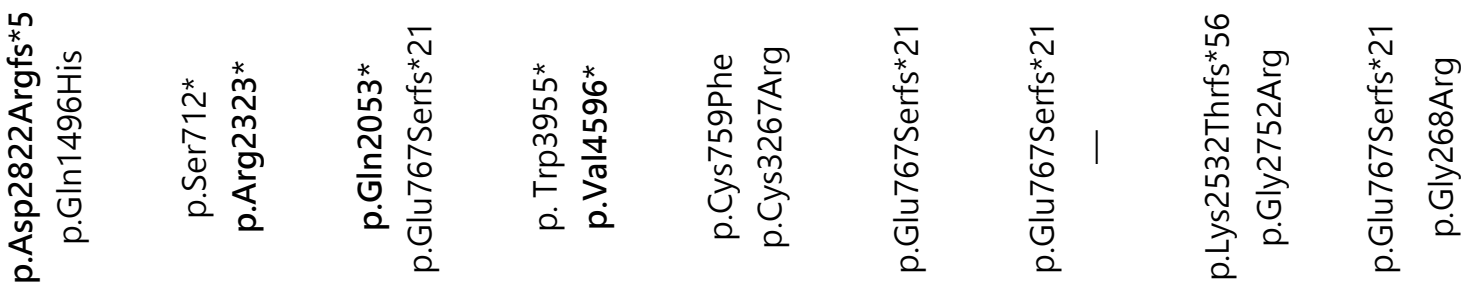

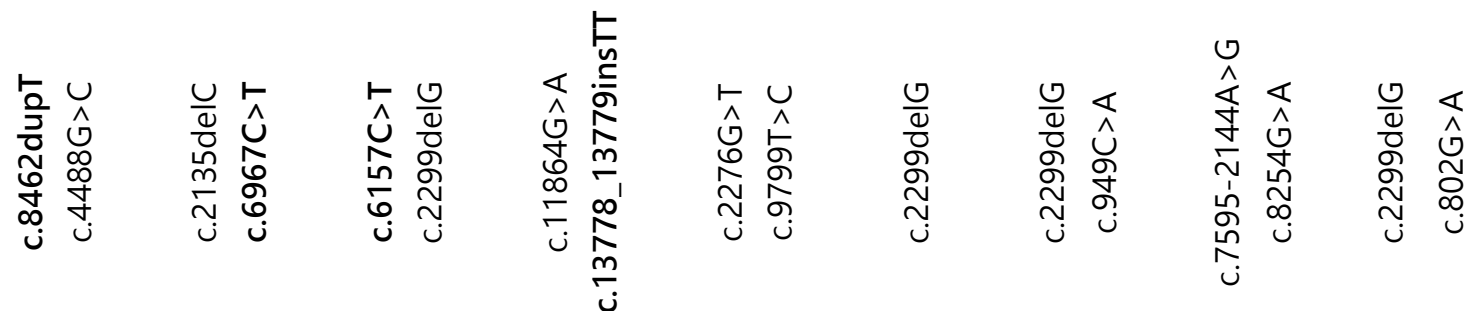

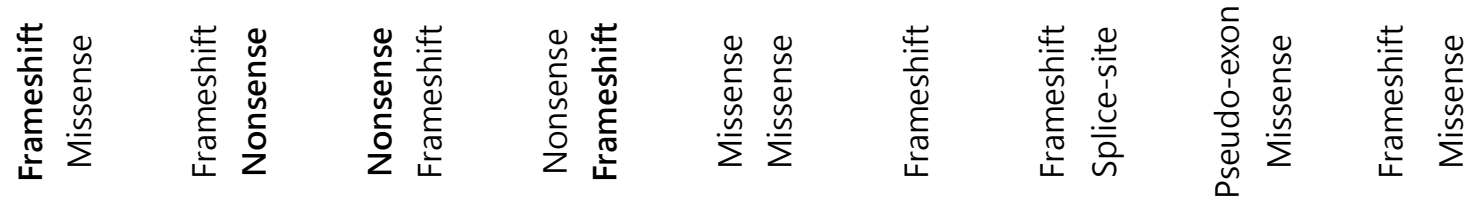

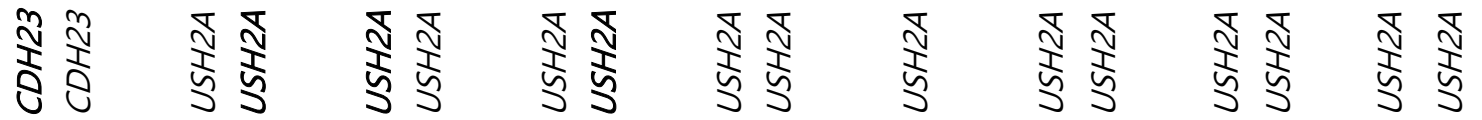

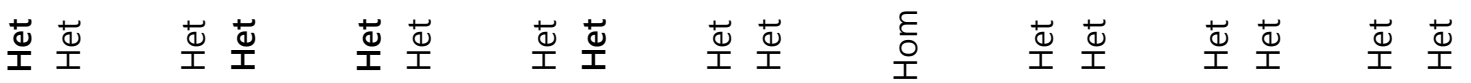

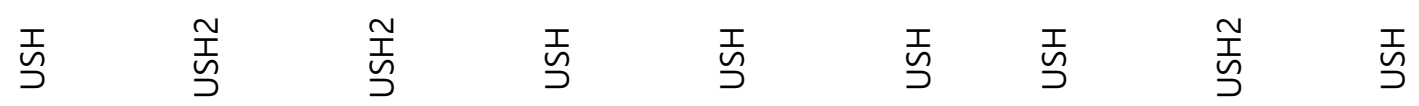

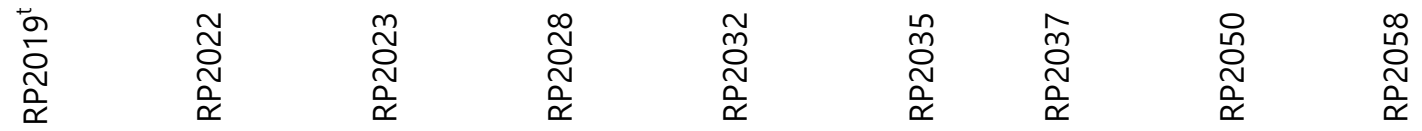




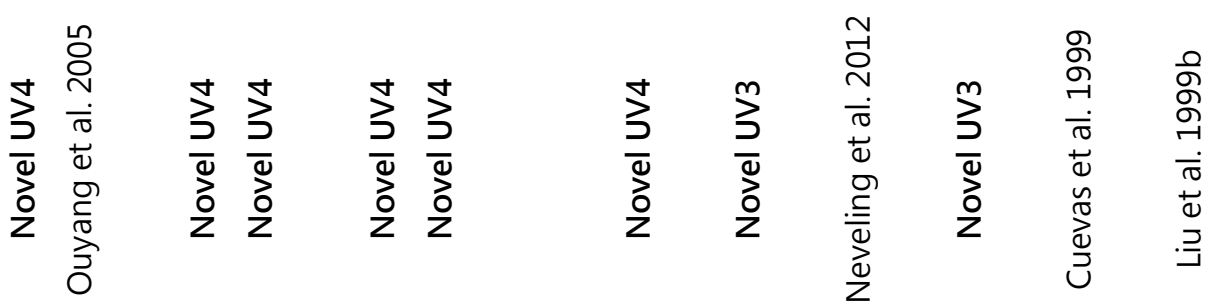

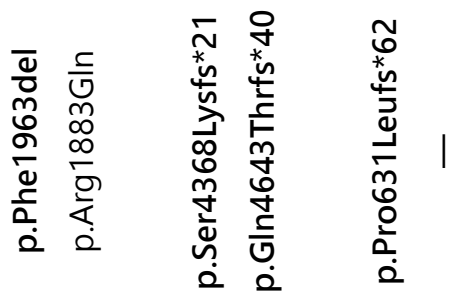

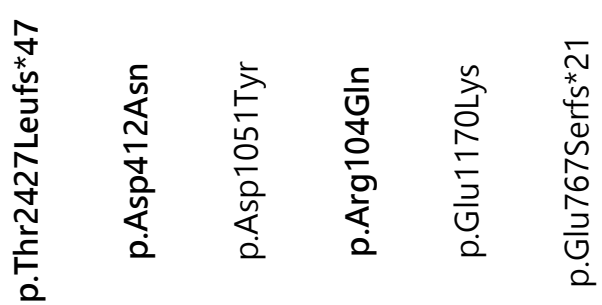

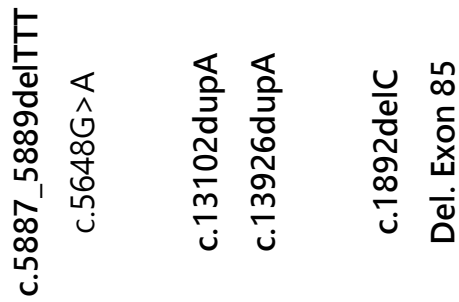

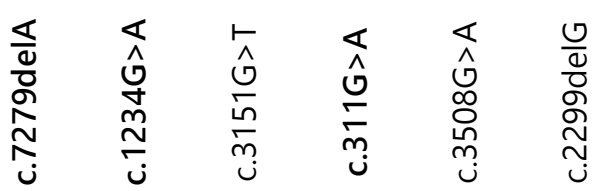

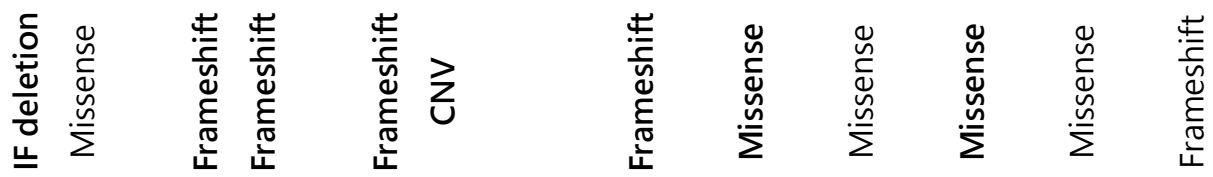

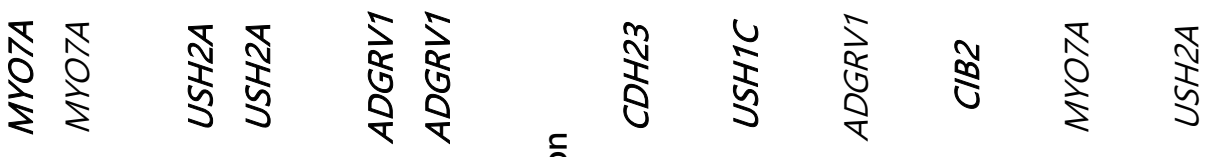

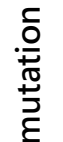

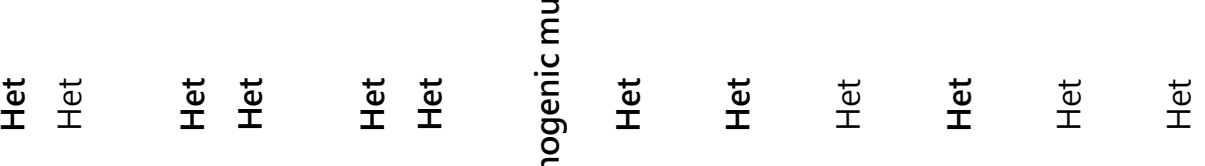

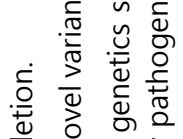

离

产言产

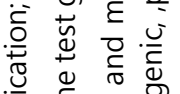

势

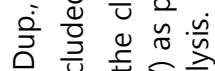

बे

है

足

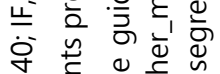

ป

खें

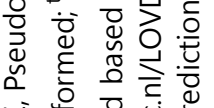

岹

造

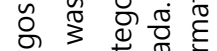

त्र

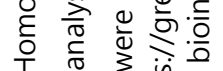

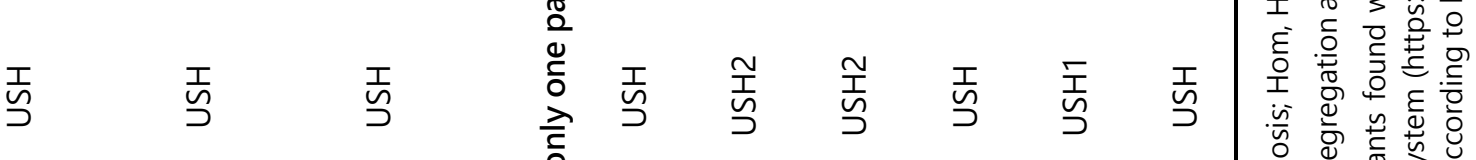

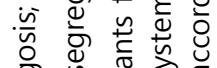

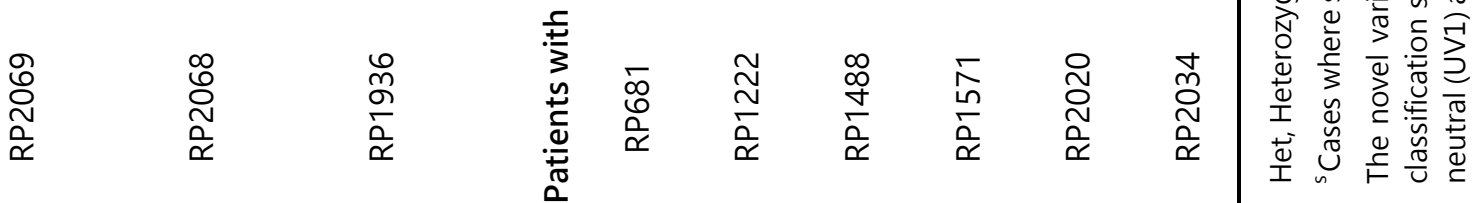


60

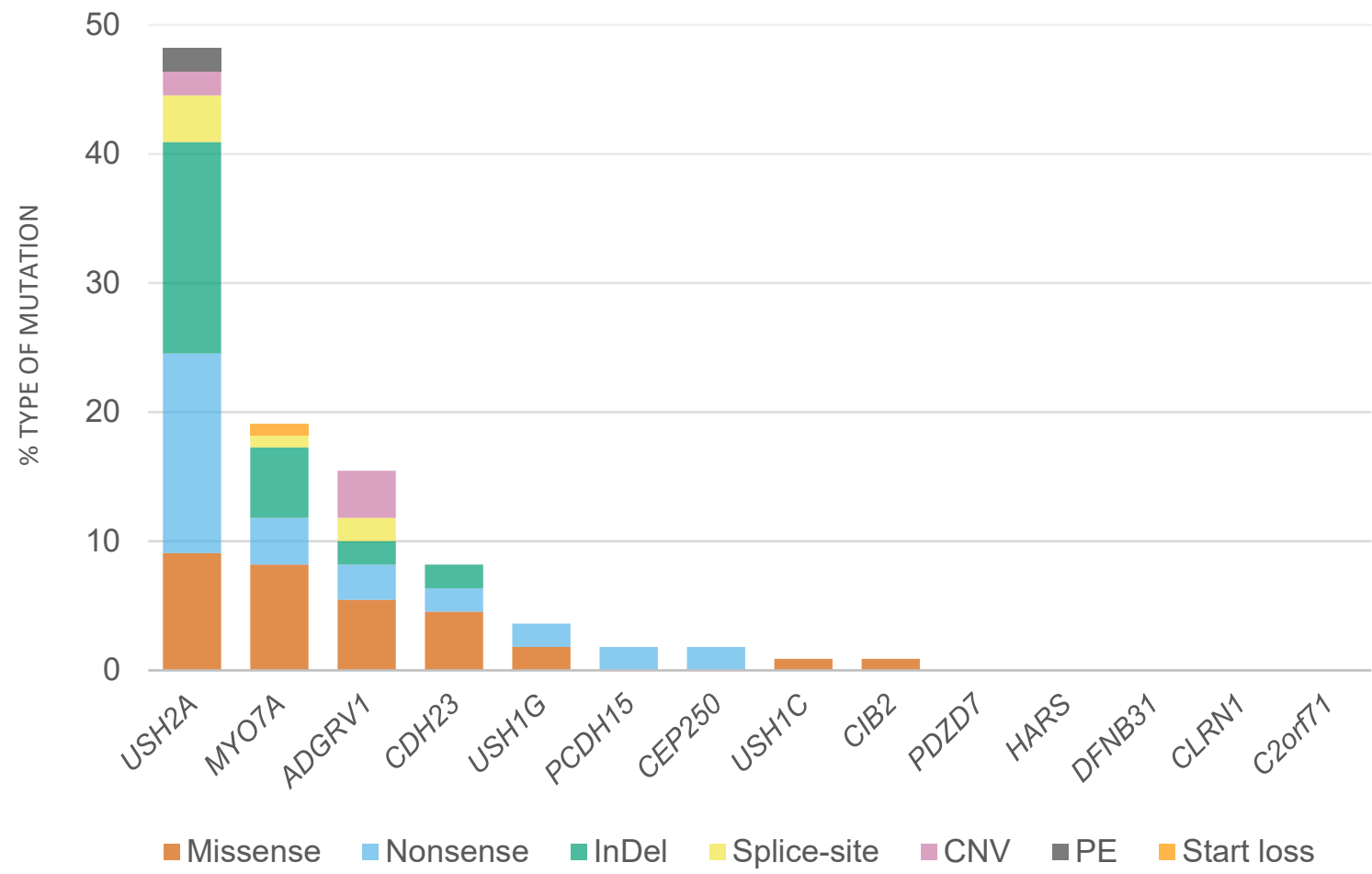

Figure 1. Recurrence of mutated genes included in the design of this study and distribution of the type of mutations. The data includes all the disease causative variants from the previously unscreened cohort and from the seven ultimately solved patients of the test group, which at the beginning of the study had only one causing mutation identified and the second was finally detected with the technology used in this work. Abbreviations: PE, Pseudo-exon; InDel, Insertion/Deletion; CNV, Copy Number Variation.

\section{Minigene splice assay analysis}

We detected 3 canonical splice-site mutations (c.1691-1G>A, MYO7A; c.5776+1G>A, USH2A; c.12295-1G>A, USH2A) and one variant with dubious consequences (c.5314-5T>A, ADGRV1) (Table 4). These variant candidates were tested through minigenes and for all of them the exon skipping was proved, confirming therefore the pathogenicity of the mutations (Figure 2).

For the c.1691-1G>A MYO7A mutation, the minigene assay was of particular interest. Besides the skipping of exon 15, the mutant allele displayed an additional aberrant band (Figure 2c). This additional fragment corresponds to the recognition of the first guanine of the exon as the acceptor site (the mutation is a transition of $G>A$ ), resulting in a frameshift effect starting at the first base of the exon. The in silico algorithms had predicted the same consequence (Table 4). 


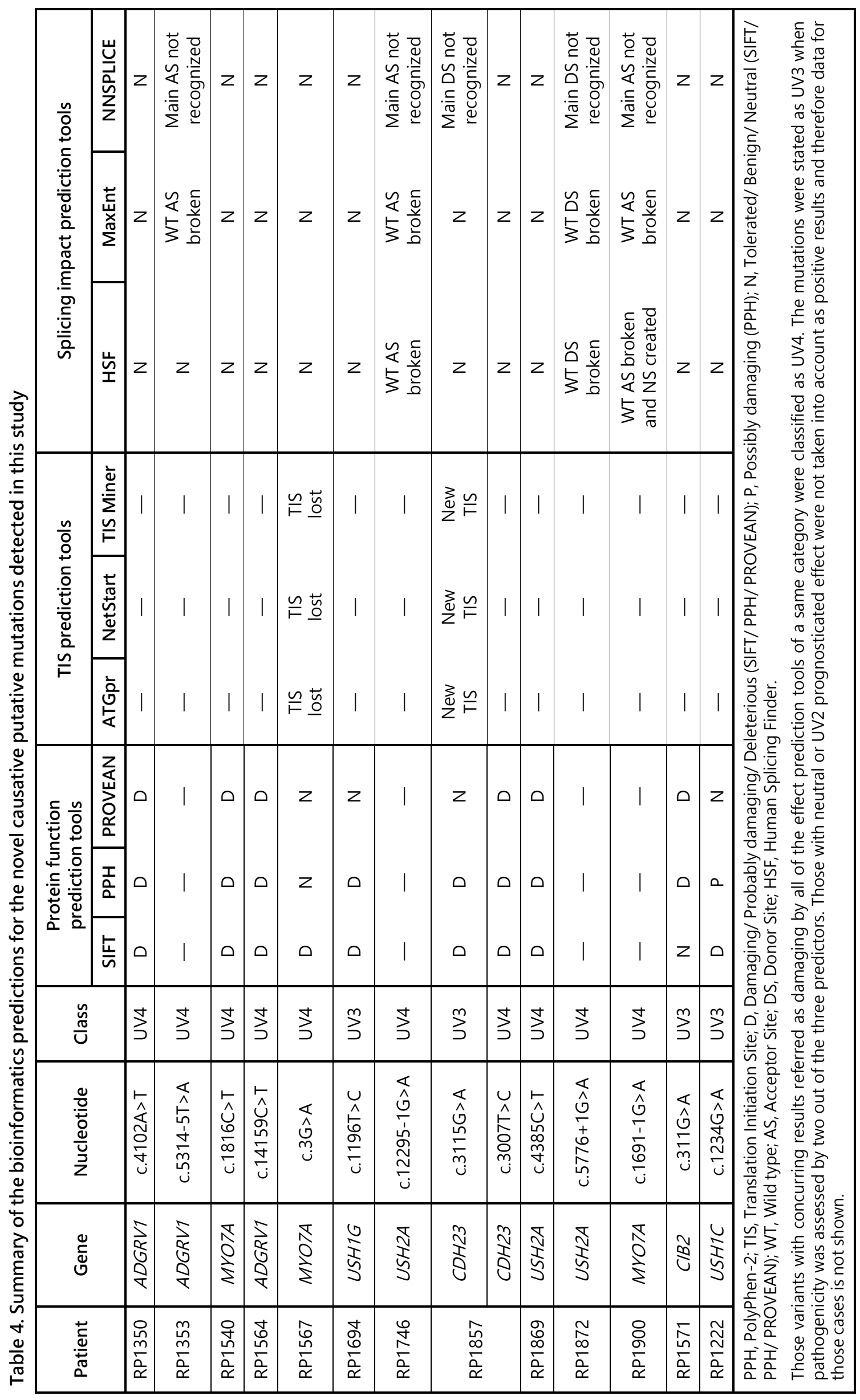



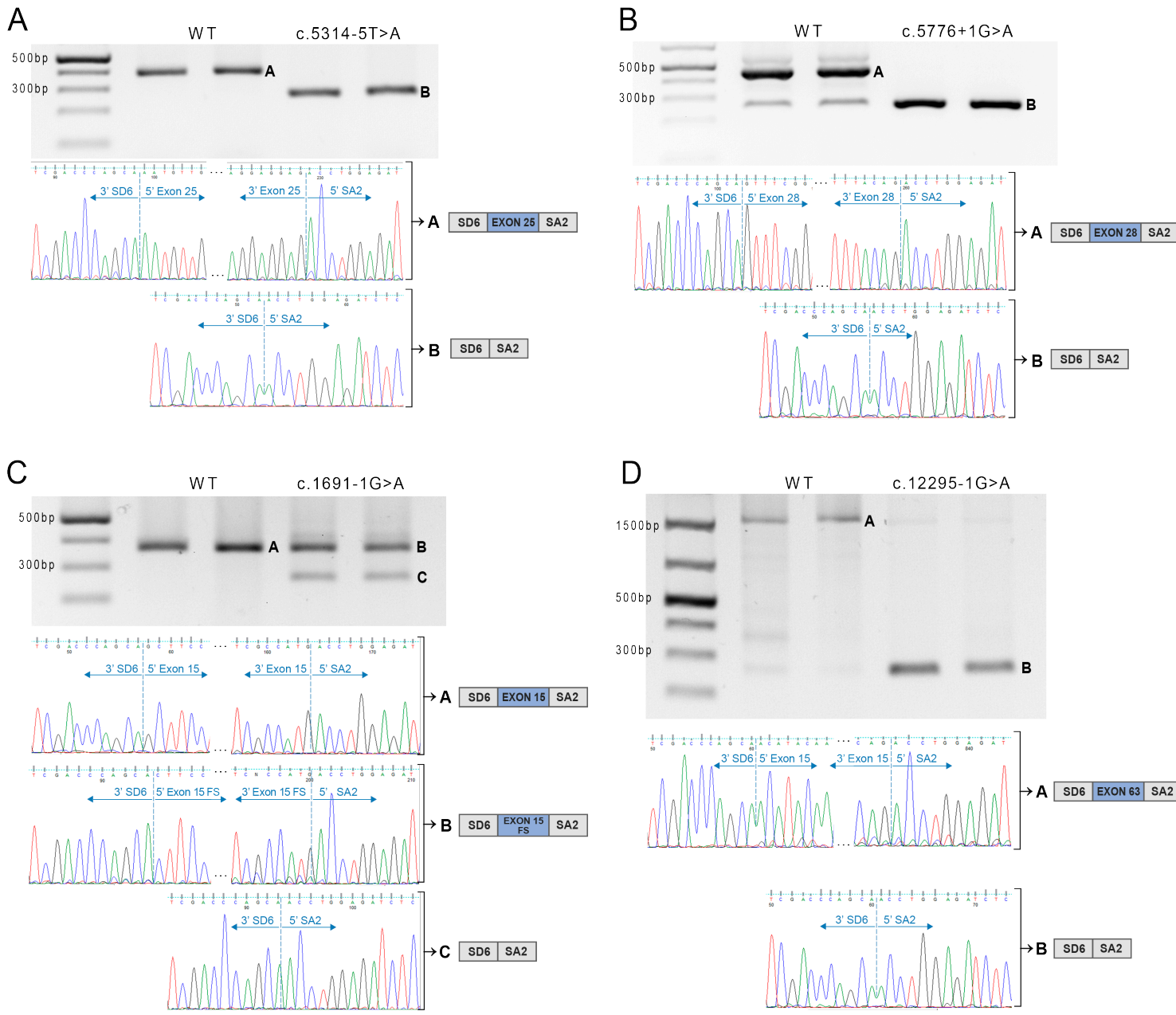

Figure 2. Minigene assay results for the four splicing mutations. The gel electrophoresis displays the splicing outcome of the minigene transcription for the WT and mutant alleles. In vitro experiments were performed in duplicate and therefore the results show both repetitions. Sanger sequencing of the results confirm the splicing processes by evidencing the transcript joints. SD6 and SA2 are the exons included in the PSPL3 exon trapping vector used in the assay. (A) c.5314-5T>A (ADGRVI). Band A corresponds to the correct transcript of exon 25. Band $\mathrm{B}$ from the mutant construction denotes the skipping of the same exon. If the transcript harboring the mutation were translated, the newly generated protein would of 1,772 amino acids in length, p.Asn1772*. (B) c.5776+1G >A (USH2A). Band $A$ is the correct transcript corresponding to the exon 28 and Band $B$ is the skipping of the same exon. If the aberrant transcript were translated, it would generate a new truncated protein of 5,134 amino acids in length, p.Gly1858_Thr1925del. (C) c.1691-1G>A (MYO7A). Band A corresponds to the correct transcript of exon 25. Band B is the aberrant splicing process due to the new site generated by the lack of a guanine at the acceptor site, entailing therefore a frameshift effect. The fragment $C$ corresponds to de exon skipping of exon 15 . If the transcript with the mutation were translated, it would generate the two proteins p. Gly564Alafs*58 and p.Phe565Argfs*11. (D) c.12295$1 G>A(U S H 2 A)$. Band A corresponds to the correct transcript of exon 63 and band $B$, from the mutant allele, evidences the skipping of the exon. The displayed images of the gels have been cropped to improve the clarity of the presentation, and the full-length gels are presented in Supplementary Figure 2. 


\section{Clinical description of RP1973}

A remarkable case was RP1973, which was found to be a compound heterozygous for two nonsense mutations in CEP250. Both nonsense mutations segregate with the family, which is composed of both parents and an unaffected sibling (Figure 3A). Patient RP1973 suffered from bilateral moderate-severe progressive hearing loss manifested at 13 years old (Figure 3B) and late-onset progressive diminution of vision in both eyes with photophobia (first ophthalmologic examination at 44 years old). There is no history of any similar condition in any other family member. The BCVA was 0.6 in the right eye and 0.5 in the left eye (Snellen). The anterior segment findings were within normal limits, but fundus examination revealed migration of pigment in a bone-spicule pattern within a midperipheral annular zone of both eyes and narrowing of the peripheral retinal blood vessels (Figure 3C). The left eye showed a glistening reflex of the inner retinal surface secondary to an epiretinal membrane. The macula of the right eye was relatively normal. Humphrey perimetry revealed peripheral visual field constriction with relative defects in the paracentral region in both eyes that has remained stable for the last five years. Macular autofluorescence images were normal in both eyes. The OCT shows a normal macular thickness with discontinuity of the outer segment layer of the photoreceptors around the foveal center in both eyes (Figure 3C). Full-field electroretinography showed only mild alterations in the scotopic flash electroretinography (ERG), as the amplitudes of the b-wave were reduced in the right eye and absent in the left eye. Macular ERG showed an absence of response in both eyes, and Visual Evoked Potentials (VEP) were altered (Supplementary Figure 1). Due to the symptoms, the nature of the variants leading to a premature stop codon and the cosegregation analysis we consider both mutations as disease causing for an USH-like phenotype.

The analysis of the targeted panel and WES results showed no additional putative pathogenic mutations, except for one heterozygous missense variant in USH2A (rs773526991: c.4561C>T/p.Arg1521Cys), presenting an allele frequency of 0.00002 in ExAC and for which the in silico tools implied a deleterious effect. Nevertheless, no other potential mutation was identified in USH2A. 
A

M1: CEP250 c.3337A>T, p.Lys1113*

M2: CEP250 c. 4006C>T, p.Arg1336
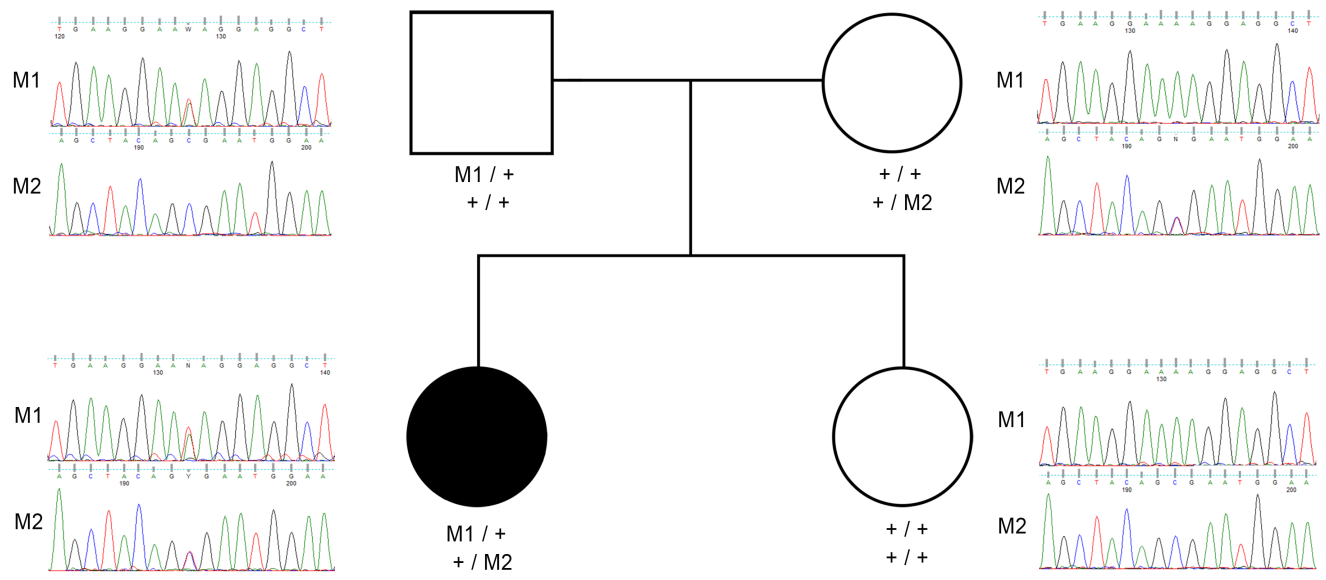

$\mathrm{B}$
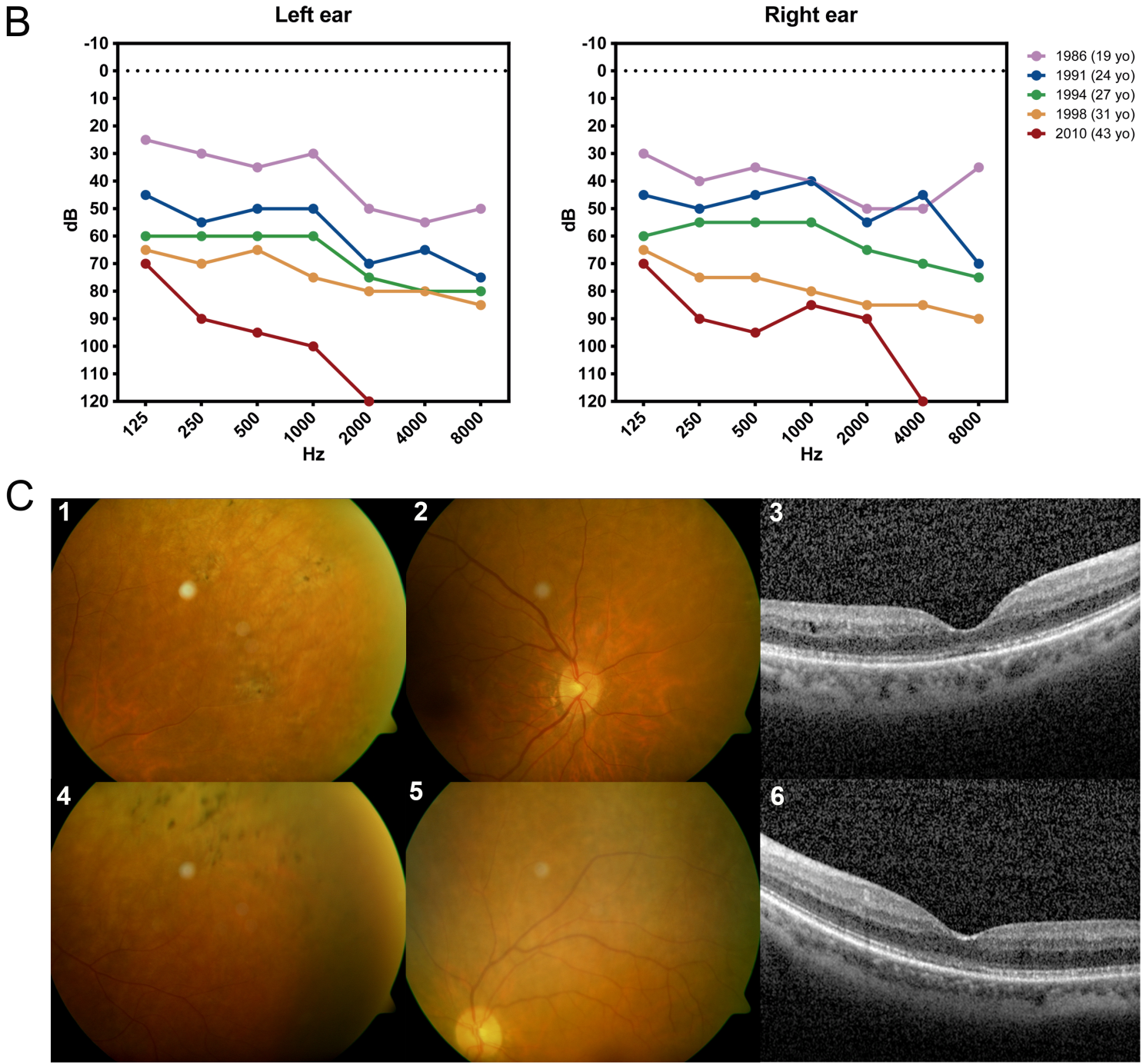

Figure 3. Clinical and molecular data of patient RP1973 harboring the nonsense mutations in CEP250. (A) Family pedigree with the Sanger sequencing results revealing the segregation pattern of the mutations. (B) Audiometric results evincing the progression of the bilateral hearing loss. (C) Ocular phenotype. Upper images correspond to the right eye, bottom images are from the left eye. Fundus pictures showing pigment clumps $(C 1, C 4)$ and thinning of the peripheral arterioles $(\mathrm{C} 2, \mathrm{C} 5)$. OCT images of the foveal region showing loss and discontinuity of the retinal pigment epithelium layer (C3, C6). Abbreviations: yo, years old; dB, decibel; Hz, hertz. 


\section{Discussion}

Usher syndrome is genetically heterogeneous mostly due to the high number of genes involved and their large size. The genetic etiopathogeny relies on all kinds of mutations among these genes and additionally, most of the variants are private. For that reason, it is very difficult to perform molecular diagnosis by conventional genotyping or direct gene sequencing. In our study, we were able to detect biallelic mutations in an USH gene in 45 out of the 58 previously unscreened patients (77.6\%) and we identified 96 out of the 116 expected mutated alleles ( $82.8 \%$ detection ratio). That percentage difference is due to the fact that 6 cases were carriers of only one pathogenic variant (Table 3). The remaining undiscovered second mutation, as well as both variants of unresolved cases, may be located either in other USH responsible still unknown genes or in other non-coding regions that were not incorporated in our design. The pathogenic deep intronic mutation c.7595$2144 \mathrm{~A}>\mathrm{G}$ in $U S H 2 A$ was included in the study, but five other have been recently designated to be pathogenic (Liquori et al. 2016, Baux et al. 2017, Khan et al. 2017), which proves that still many deep intronic mutations may remain unveiled and further whole gene screen studies are of great interest.

The output of the analysis of the raw data is very dependent on the algorithm used for the mapping and variant calling. Two control variants, consisting of frameshift duplications, were detected only when relaxing the software quality parameters, suggesting a possible hindrance for the Ion Torrent mapping algorithm to align homopolymers. Indeed, other studies have reported these homopolymer-associated errors and even over and undercalling errors in non-homopolymer regions (Bragg et al. 2013, Song et al. 2017). Additional factors for this technology suggested by other authors, such as the biases produced by the GC content or the underestimation of the quality scores (Loman et al. 2012, Bragg et al. 2013), probably contribute to the false negative calling errors.

The platform and panel design provided a $91 \%$ reliability based on the point mutation detection rate of the test group, but it reached a 100\% of accuracy when thresholds of the mapping and annotation variables were decreased. However, no additional causative variants were found in the group of unresolved cases after applying the same procedure. Nevertheless, the failure to detect these variants could also fall on the HTS system used for the study, escaping variant detection independently on the resulting data management.

Among the study, two patients from the previously unscreened group presented mutations in genes that were not consistent with their clinical diagnosis, being these genes 
usually responsible for another USH subtype. One USH1 patient (RP1748) carried biallelic mutations in USH2A and an USH2 case in the MYO7A gene (RP1567). Still, the event of a molecular diagnosis not quite matching the clinical phenotype is not unusual and has been previously reported in other studies (Bonnet et al. 2011, Aparisi et al. 2014). Indeed, this supports the further investigation of USH patients by HTS to establish better genotypephenotype associations.

Many previous studies have evidenced the presence of large rearrangements among different USH populations, establishing them as a significant genetic alteration causing the disease. PCDH15 and USH2A are the most common genes displaying such CNVs (Aller et al. 2010a, García-García et al. 2014), but also large rearrangements have been found in MYO7A, CDH23 and ADGRV1 (Roux et al. 2011, Besnard et al. 2012).

A CNVs survey based on the coverage of the sequencing results was not possible due to the wide deviation of the target enrichment technique by loci amplification. However, large homozygous deletions could be inferred from null covered regions corresponding to several adjacent probes, when observed in punctual cases. The supplemental analysis by MLPA or aCGH allowed us to detect a total of five large rearrangements among the test group and the previously unscreened cohort, four of these rearrangements being novel. Concerning our series of patients without prior genetic diagnosis, the CNVs account for $5.2 \%$ of the total identified pathogenic alleles.

Four of the novel mutations were intronic variants located in splicing regions that, though all but one were set on canonical \pm 1 loci, a sort of functional analysis would provide further support of their pathogenicity. Certainly, the minigene assays proved that all these four mutations cause an aberrant splicing.

Regarding the compound heterozygous case for the two nonsense mutations in CEP250, our study provides sufficient data for the gene to be classified as USH-like causative. The association was firstly introduced in a study of a consanguineous family of Iranian Jewish origin characterized by early onset hearing loss and mild RP (Khateb et al. 2014) and, very recently, Kubota et al. (2018) presented a Japanese family carrying compound heterozygous nonsense mutations in CEP250, with a clinical phenotype of cone-rod dystrophy and sensorineural hearing loss. Our patient with the CEP250 mutations (RP1973) presented with progressive hearing loss and mild macular affectation with lowering of the visual acuity and photophobia, which are similar symptoms to those of the latter work, thus consolidating its role as a gene responsible for mimicking Usher syndrome. It has to be remarked that RP1973 
shows a clearly progressive SNHL, yet the aforementioned studies do not give any details about the deafness evolution and, thus, a full comparative analysis is not feasible. There is another study correlating CEP250 with non-syndromic RP (nsRP) due to a detected homozygous missense mutation (de Castro-Miró et al. 2016). These findings are in agreement with ours and other authors observations that different diseases can be caused by the same gene depending on specific mutations, such as USH2A that can cause either nsRP or USH, or the USH genes MYOTA, USH1C, CDH23, PCDH15, USH1G, WHRN or CIB2 that can cause non-syndromic hearing loss or USH (Weil et al. 1997, Bork et al. 2001, Ahmed et al. 2002, 2003, Ouyang et al. 2002, Mburu et al. 2003, Riazuddin et al. 2012, Maria Oonk et al. 2015). In view of the different but closely related phenotypes associated to CEP250, thorough clinical examinations of the cases should be performed to better understand the consequences of mutations in this gene, particularly those regarding cone affectation.

In the last years, the USH molecular diagnosis through HTS approaches have replaced the traditional techniques based on Sanger sequencing (Bonnet et al. 2011, Le Quesne Stabej et al. 2012). The more recent next generation sequencing approaches enable a detection ratio between $50-100 \%$, depending on the cohort and design of study (Aparisi et al. 2014, Besnard et al. 2014, Oishi et al. 2014, Jiang et al. 2015, Qu et al. 2015, Bonnet et al. 2016, Eandi et al. 2017). Here, we provide a HTS method based on targeted exome library generation by amplification and the subsequent ion sensing-based sequencing that allows an average allele detection ratio compared to the other mentioned studies. It is, though, unfair to compare these varying efficiencies, since they do not only rely on the sequencing system, but also on the cohort selection criteria of the samples. For instance, the group analyzed by Qu et al. (2015), Besnard et al. (2014) and Eandi et al. (2017) consisted of only five, thirteen and seventeen probands respectively, a rather scarce number of samples that might bias the efficiency outcome. Additionally, those and other studies such as (Aparisi et al. (2014) and Bonnet et al. (2016) involved only well USH characterized patients. Our study not only included a larger number of samples, but also some unclassified USH cases. Therefore, another partial reason for the unsolved cases could be the misdiagnosis of some patients as USH, who could harbor several mutations in other genes that together may mimic the syndrome. From the seven unresolved patients without genetic diagnosis, three lack in detailed clinical notes that clearly support the cases as USH. The remaining four patients do not fully harmonize with the syndrome, since they present a late-onset hearing impairment. If we were not to take these samples into account, the detection ratio would increase from the $82.8 \%$ up to $94.1 \%$. Even displaying such a solid outcome, this HTS 
approach falls short of CNV detection, yet it allows the use of only $10 \mathrm{ng}$ of starting DNA (admitting as well some degradation). All these features shall be taken in consideration, depending on the requirements and resources of each center and the group of study.

Our updated custom design for USH targeted exome sequencing is a reliable tool for molecular diagnosis of the disease, and its implementation in the health care system would lead to a great profit for the patients. Furthermore, CEP250 should be officially recognized as a gene causative of Usher-like syndrome.

\section{Data Availability Statement}

The datasets generated and analyzed during the current study are available from the corresponding author on reasonable request.

\section{Acknowledgements}

Acknowledgements Tis work was supported by the Institute of Health Carlos III (ISCIII) and the European Development Regional Funds (grants PI13/00638, PI16/00425, PI16/00539), and by a grant from Fundación ONCE (grant 2015/0398). C.F.G. is a recipient of a fellowship from the ISCIII and the European Social Fund (IFI14/00021). G.G.G. is recipient of a senior postdoctoral contract from CIBERER. Ion Proton and PGM were acquired thanks to a grant (PIE13/00046) bestowed by the ISCIII.

\section{Author Contributions}

C.F.G., E.A. and J.M.M. conceived and designed the study. C.F.G., G.G.G., T.J., N.F., E.A. and J.M.M. performed the molecular experiments and analyzed the data. M.F.B. and A.S.D.M. provided the RP1973 sample and carried out the clinical evaluation of the patient. C.F.G. drafted the manuscript. J.M.M. and C.A. obtained the funding and provided the samples. C.F.G., G.G.G., T.J., E.A. and J.M.M. reviewed the manuscript.

\section{Additional Information}

Supplementary information accompanies this paper at https://doi.org/10.1038/s41598-018-35085-0 and in the Appendix section of the present dissertation document. 




\section{CHAPTER III}

\section{Expanding the genetic landscape of Usher-like phenotypes}

Carla Fuster-García ${ }^{1,2}$, Gema García-García ${ }^{1,2}$, Teresa Jaijo ${ }^{1,2,3}$, Fiona Blanco-Kelly ${ }^{2,4}$, Lifeng $\operatorname{Tian}^{5}$, Hakon Hakonarson ${ }^{5,6}$, Carmen Ayuso ${ }^{2,4}$, Elena Aller ${ }^{1,2,3}$, José M Millán ${ }^{1,2}$.

\footnotetext{
${ }^{1}$ Grupo de Investigación en Biomedicina Molecular, Celular y Genómica, Instituto de Investigación Sanitaria La Fe (IIS La Fe), Valencia, Spain. ${ }^{2}$ CIBER de Enfermedades Raras (CIBERER), Madrid, Spain. ${ }^{3}$ Unidad de Genética y Diagnóstico Prenatal, Hospital Universitario y Politécnico La Fe, Valencia, Spain. ${ }^{4}$ Servicio de Genética, Fundación Jiménez Díaz, University Hospital, Instituto de Investigación Sanitaria Fundación Jiménez Díaz IIS-FJD, UAM, Madrid, Spain. ${ }^{5}$ Center for Applied Genomics, The Children's Hospital of Philadelphia, Pennsylvania, USA; ${ }^{6}$ Department of Pediatrics, The Perelman School of Medicine, University of Pennsylvania, Philadelphia, PA, USA.
}

Investigative Ophalmology \& Visual Science, Volume 60, p4701-4710 (2019) doi: 10.1167/iovs.19-27470 (Adapted to meet the format of the present dissertation) 


\section{Abstract}

Purpose: Usher syndrome (USH) is a rare disorder characterized by retinitis pigmentosa (RP) and sensorineural hearing loss. Several genes are responsible for the disease, but not all cases are explained by mutations in any of these, supporting the fact that there remain other unknown genes that have a role in the syndrome. We aimed to find the genetic cause of presumed USH patients lacking pathogenic mutations in the known USH genes.

Methods: Whole exome sequencing was performed on a priori USH-diagnosed subjects from nine unrelated families, which had shown negative results for an USHtargeted panel in a previous study.

Results: We identified possible pathogenic variants in six of the studied families. One patient harbored mutations in REEPG and TECTA, each gene tentatively causative of one of the two main symptoms of the disease, mimicking the syndrome. In three patients, only the retinal degeneration causative mutations were detected (involving EYS, WDR19, and CNGB1 genes). Another family manifested a dementia-linked retinal dystrophy dependent on an allele dosage in the GRN gene. Last, another case presented a homozygous mutation in $A S I C 5$, a gene not yet associated with USH.

Conclusions: Our findings demonstrate that pending cases should be clinically and genetically carefully assessed, since more patients than expected may be either related phenocopies or affected by a more complex disease encompassing additional symptoms rather than classical USH. 


\section{Introduction}

Usher syndrome (USH) is considered the principal hereditary disorder involving sensorineural bilateral hearing loss $(\mathrm{HL})$ and retinitis pigmentosa (RP). It is an autosomal recessive disease, with a prevalence up to 6.2/100,000 (Millán et al. 2011). There are three clinical types of USH depending on the severity and progression of the symptoms. Type 1 (USH1) is the most severe category and it is characterized by a severe-profound congenital $\mathrm{HL}$ and onset of RP during childhood. Additionally, patients with this type also present with vestibular dysfunction. Type 2 (USH2) is the most common type and the patients display moderate-severe congenital hearing impairment and adult-onset RP. Type 3 (USH3) is defined by progressive postlingual $\mathrm{HL}$, variable onset of $\mathrm{RP}$, and sometimes also absence of vestibular function (Millán et al. 2011).

USH is a genetically heterogeneous disease, since there are currently 10 responsible genes, namely MYO7A, USH1C, CDH23, PCDH15, USH1G, CIB2, USH2A, ADGRV1, WHRN, and CLRN1 (Mathur and Yang 2015). In addition, another five genes also have been associated with the disease in some studies, yet it is more sensible still to consider them as causative of a non-USH form of deafblindness, given that the symptoms of these cases do not fully match the usual clinical picture and some even manifest other comorbidities: ARSG, CEP250, CEP78, ESPN, HARS, and PDZD7 (Ebermann et al. 2010, Puffenberger et al. 2012, Khateb et al. 2014, 2018, Fu et al. 2017, Ahmed et al. 2018).

Consequently, the gold standard to date for the molecular diagnosis of USH patients is by means of targeted exome sequencing (Oishi et al. 2014, Eandi et al. 2017, Fuster-García et al. 2018). However, not all USH cases are explained by mutations in the coding regions of any of the USH genes, implying that there remain other unknown genes causing the disease or pathogenic variants in the non-coding regions of the USH genes.

Furthermore, some cases could result from concurrence of the two main symptoms caused by mutations in separate genes; therefore, mimicking the syndrome (DeLuca et al. 2015, Neuhaus et al. 2017), or due to other syndromes that also associate a retinal dystrophy (RD) and $\mathrm{HL}$, such as polyneuropathy, hearing loss, ataxia, retinitis pigmentosa and cataracts (PHARC) or Heimler syndrome (Raas-Rothschild et al. 2002, Eisenberger et al. 2012, FusterGarcía et al. 2018). Taking this prospect into account, the genes responsible for nonsyndromic RP (nsRP) and HL independently should be considered, as well as those associated with more complex diseases with those symptoms among its spectrum. 
We unveil the genetic landscape underlying cases with an USH-like phenotype yet negative for the USH genes, and unveil new insights of either new candidate genes or to resolve the genetic puzzle. For this purpose, we performed whole exome sequencing (WES) in probands from nine unrelated families that had been screened previously through our implemented targeted panel (Fuster-García et al. 2018).

\section{Methods}

This study was approved by the Hospital La Fe and the FJD Ethics Committee, according to the tenets of the Declaration of Helsinki, and all research was performed in accordance with the relevant guidelines and regulations. Authorizations from all the patients and the participating relatives were obtained by signing an informed consent form.

\section{Subjects}

A total of 10 Spanish patients with suspected Usher syndrome from nine unrelated families were selected for the WES analysis. These probands consisted of unsolved cases from a previous screening assay through a custom USH targeted panel (Fuster-García et al. 2018). Subjects from families FRP-480, FRP-581, FRP-613, FRP-616, and FRP-621 were recruited by the Hospital La Fe. Patients belonging to families FRP-70, FRP-426, FRP-520, and FRP-539 were referred from the Fundación Jiménez Díaz University Hospital.

\section{WES and data analytic workflow}

Genomic DNA (gDNA) from the probands was obtained and purified using standard procedures. The concentration of the resulting DNA samples was determined with Nanodrop and Qubit fluorometer (Thermo Fisher Scientific, Waltham, MA, USA). WES was performed in all USH probands, except for a large family where only one affected sibling was sequenced (FRP-480). Sequencing and data processing before the filtering was done at the Center for Applied Genomics of The Children's Hospital of Philadelphia. Exome enrichment of the samples was performed using Agilent Select Human All Exome V5 kit.

The Dynamic Read Analysis for GENomics platform (DRAGEN, version 2.3.1; Illumina, San Diego, CA, USA) was used for the read mapping, duplicate reads marking, and haplotype-based variant calling in regards of the GRCh37 with decoy sequences (hs37d5) reference human genome. The ANNOVAR tool was used for the variant annotation (Wang et al. 2010). 
The resulting variants were filtered based on cutoff for the maximum minor allele frequency $\leq 1 \%$ in the International Genome Sample Resource (1000 Genomes Project, 1000g), gnomAD, and ExAC. Nonsense, frameshift, splice-site, and pathogenic-predicted missense and synonymous variants were prioritized. The pathogenicity of missense and synonymous variants was determined according to the prediction of several in silico tools depending on the type of mutation. Missense mutations were evaluated using the scores provided by SIFT, PolyPhen, and Mutation Taster. Synonymous variants were considered when located near the exon boundaries and with a predicted effect by the Human Splicing Finder 3.1. Additional deleteriousness analyses based on conservation parameters were performed for the missense variants, specially in regards to the assessment of novel amino acid changes. To this end, GERP++, phyloP, and SiPhy score values were taken into account (Garber et al. 2009, Davydov et al. 2010, Pollard et al. 2010), and alignment variant-enclosing amino acid sequence across several species was performed. The pathogenicity interpretation of all the novel variants presented in this study was rated according to the American College of Medical Genetics and Genomics (ACMG).

Additionally, a focalized survey was done, namely of variants already described as pathogenic in ClinVar or the Human Gene Mutation Database (HGMD), and of genes matching the phenotype. The latter assessment was performed using the genes associated with either nsRP, HL, or syndromes involving those symptoms, as listed in the Retinal Information Network (RetNet), the Deafness Variation Database, and OMIM.

Furthermore, an analysis to explore possible copy number variations (CNVs) was conducted using the DECoN too (Fowler et al. 2016).

In general, variants concordant with the expected inheritance were more exhaustively scrutinized, but no genetic scenario was discarded.

The validation of the candidate mutations and segregation analysis were performed through conventional Sanger sequencing. Primer sequences are available upon request.

\section{Mitochondrial mutational survey}

The genetic causes producing sensorineural $\mathrm{HL}$ are very variable, and many cases presenting the symptom are due to mitochondrial mutations. The m.1555A>G and $\mathrm{m} .1494 \mathrm{C}>\mathrm{T}$ in the MT-RNR1 gene are a frequent cause of aminoglycoside-induced and non-syndromic HL (Usami and Nishio 1993). Another common mitochondrial variant associated to hearing impairment is $\mathrm{m} .3243 \mathrm{~A}>\mathrm{G}$ in $M T-T L 1$, which usually leads to syndromic HL and to a lesser extent non-syndromic HL (Tamagawa et al. 1997, Pickett et al. 
2018). In those cases where the HL was not explained by any of the variants found after the high-throughput sequencing screening, an additional targeted analysis through direct Sanger sequencing was performed looking for said deafness-associated mitochondrial variants, which were not contemplated in the WES design used in this study.

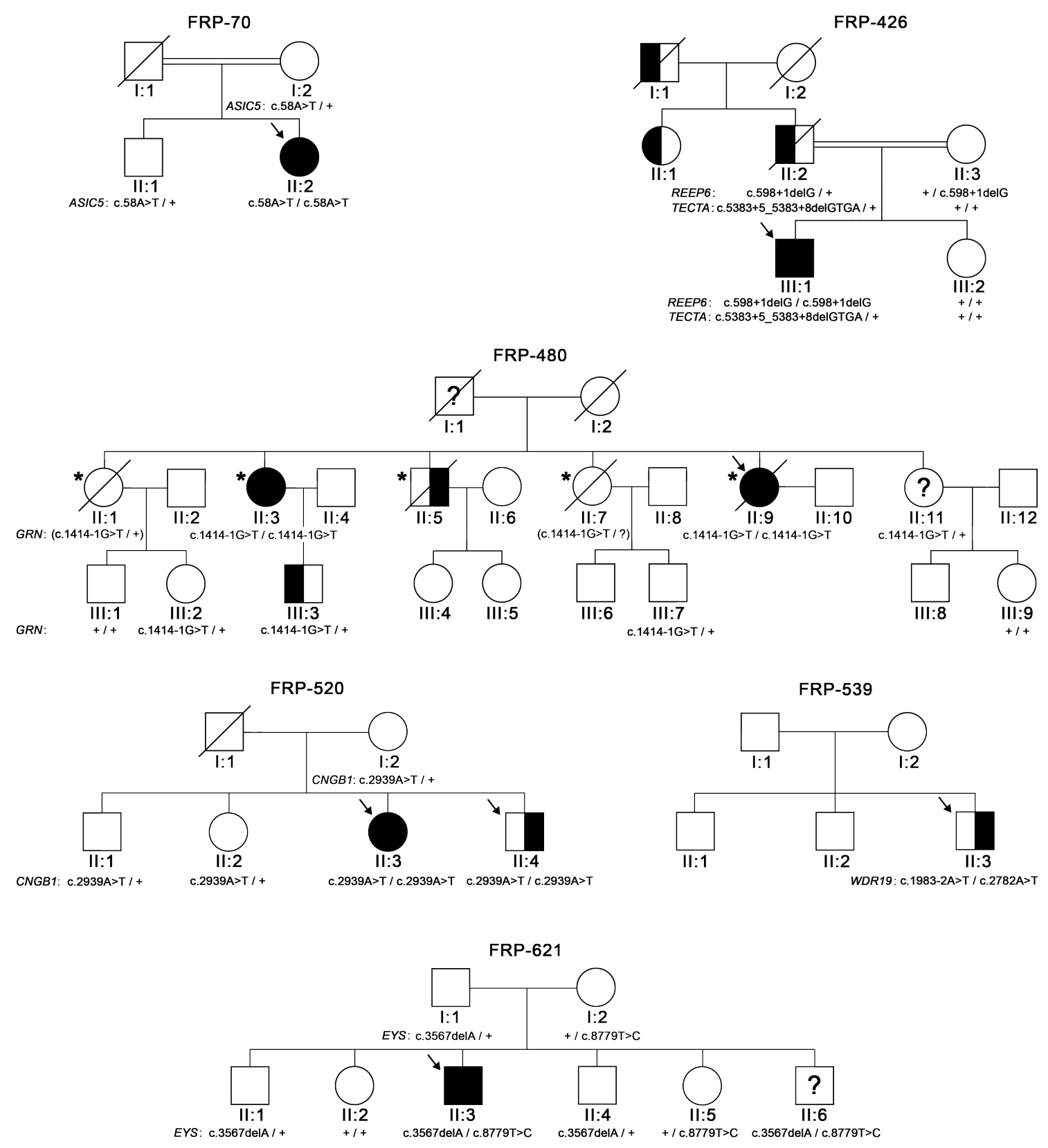

Figure 1. Pedigrees of the families with genetic findings. Left dark filling indicates affected by HL. Right dark filling indicates affected by RP. *Affected by dementia. Bracketed mutations are inferred from the confirmed genotype of the descendants. 


\section{Results}

Six of the nine families investigated harbored either the causative variants in known disease-associated genes, or candidate mutations in new genes suggesting a possible role in the phenotype (see the pertinent pedigrees in Figure 1). Basic clinical data were obtained before the variant analysis; however, the information was extended afterwards to check if the findings matched the related phenotype, as well as for those cases where the causative mutation was not detected firsthand. For an overview of the clinical evidences see Table 1. All causative mutations and the proposed putative pathogenic variants detected in this study are available in Table 2. Information about the conservation of the missense changes and ACMG classification of the novel variants is available at Supplementary Table 1, 2 and 3, respectively.

\section{Family FRP-70}

The sporadic proband of this consanguineous family was referred as a typical USH1 patient, as he presented with profound congenital $\mathrm{HL}$ and early onset RP. The homozygous nonsense variant c.58A > T (p.Lys20*) in AS/C5 (OMIM: 616693), a gene of unknown function, was identified in the patient and cosegregation among the family members was confirmed (Figure 1). The variant was absent in all the databases (1000g, ExAC, gnomAD, dbSNP), albeit for a European (non-Finnish) carrier in heterozygosis among the gnomAD database excluded from the control dataset, accounting for an allele frequency of 0.000004 .

\section{Family FRP-426}

The proband from this family was referred to us as having $\mathrm{USH} 2$, since he presented with moderate-severe congenital HL and late-onset RP. This is a consanguineous family, since the parents of the patient are second cousins, and there were no other RP affected cases in the family.

Analysis of the WES results revealed the novel homozygous pathogenic (as per AMCG standards) mutation c.598+1delG in the REEP6 gene (OMIM: 609346)(Arno et al. 2016), which is described as responsible for autosomal recessive RP (ARRP) and cosegregated with this symptom in the family. In addition, we detected the heterozygous small deletion c.5383+5_5383+8delGTGA in TECTA (OMIM: 602574) (Hildebrand et al. 2011, Lezirovitz et al. 2012, Kim et al. 2015), a gene causative of autosomal dominant and recessive deafness. After these results, new family assessment of $\mathrm{HL}$ demonstrated that the father, and the paternal aunt and grandfather also presented with deafness (Figure 1). 


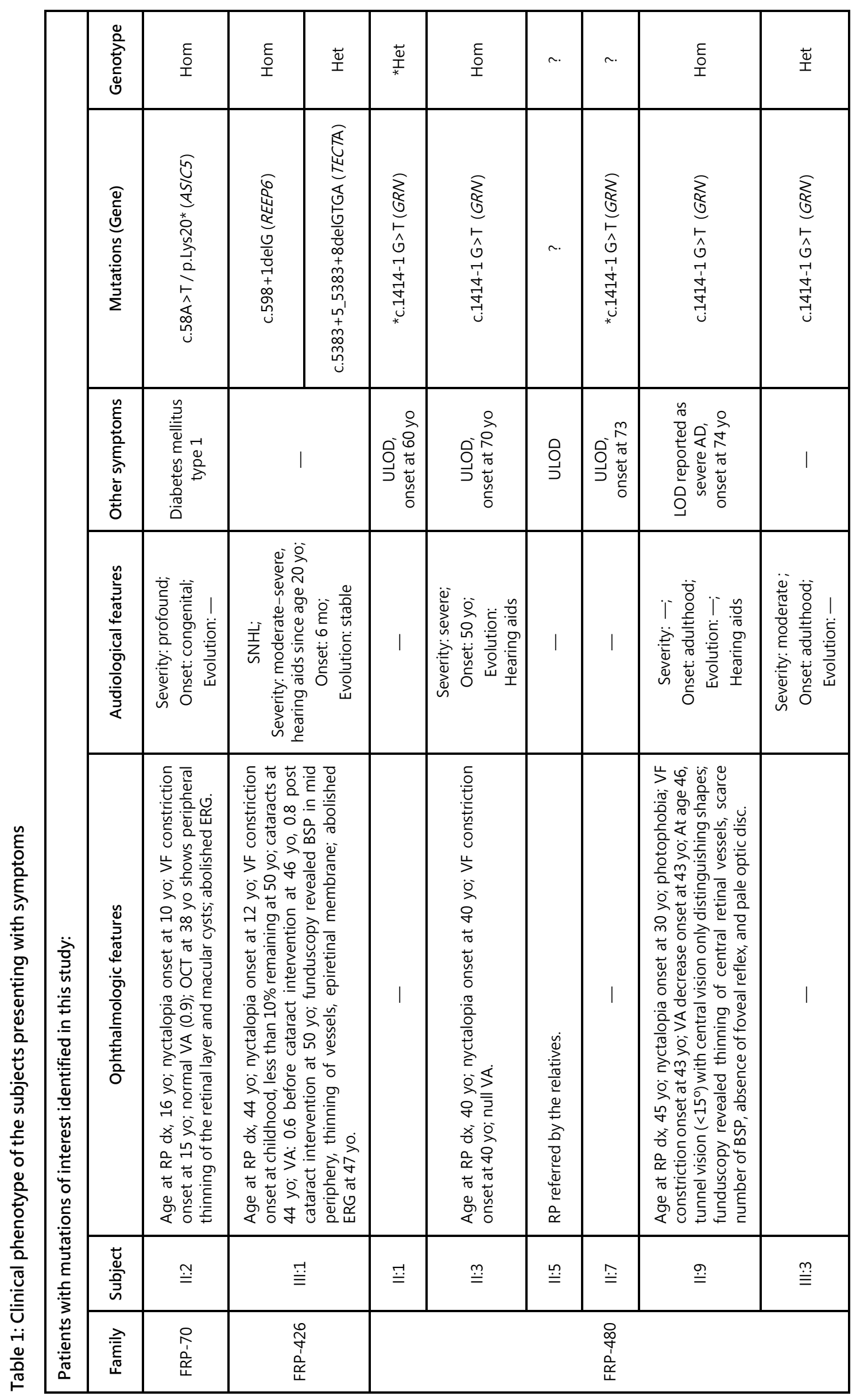




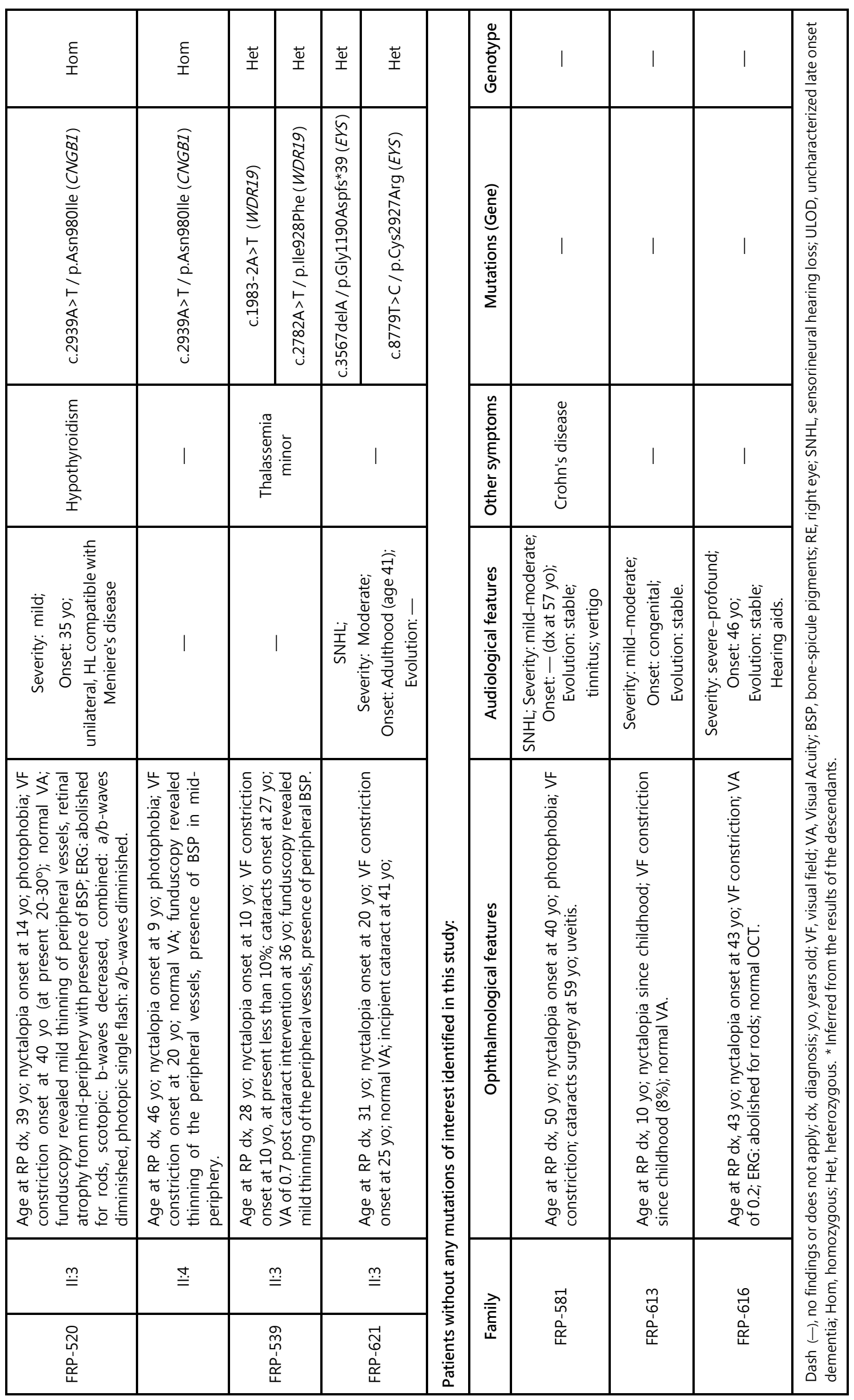




\section{Family FRP-480}

The referred patient from this family (Il:9) presented with late-onset retinal degeneration with a very rapid progression and HL. In addition, she also suffered from an uncharacterized dementia starting in her seventies, which was referred to as severe Alzheimer's disease (AD). Analysis of the sequencing results exposed the splice-site mutation c.1414-1G>T in GRN (OMIM: 138945) in the homozygous state, a gene mainly associated with frontotemporal dementia (FTD) or neuronal ceroid lipofuscinosis (NCL) depending on the allele dosage (Ward et al. 2017).

Members within this same family presented with variable clinical manifestations (Table 1 and Figure 1). Both progenitors ( $1: 1$ and $I: 2)$ must have been obligate carriers of the mutation. The father died of lung cancer at 55 years of age, making impossible to know if he would have manifested the disease later in his life. The mother did not display any of the visual or neurological symptoms, yet two of her brothers had manifested behavior changes compatible with FTD (not shown in the pedigree). Concerning the sibs, clinical history and the genetic screening were hampered by the fact that the majority were deceased, but some genotypes could be inferred by testing the alleles of the descendants. The only to date completely unaffected sister (II:11) also is a carrier of the mutation in progranulin. However, she is presently 74 years old, which is more or less the same age when most of her siblings started to manifest the dementia symptoms, and therefore, her health status remains unclear.

\section{Family FRP-520}

Both affected siblings were included in the sequencing study, which revealed the homozygous mutation c.2939A>T (p.Asn980lle) in the CNGB1 gene (OMIM: 600724), previously reported as causative of ARRP (Simpson et al. 2011). No likely pathogenic variants explaining the $\mathrm{HL}$ were found.

\section{Family FRP-539}

The only affected member of this family was diagnosed with RP at 28 years of age, but he stated he began noticing the beginning of the symptoms in childhood (Table 2). Sequencing analysis revealed that he was compound heterozygous for the two novel mutations c.1983-2A>T and c.2782A>T (p.lle928Phe) in WDR19 (OMIM: 608151), a gene 
mostly related to multisyndromic RP (Bredrup et al. 2011). In concordance with the evolutionary constraint scores obtained by the conservation-based programs (Supplementary Table 1), the interspecies alignment of the amino acid sequence comprising the novel missense variant revealed that the position is highly conserved (Supplementary Table 2). The segregation analysis could not be fulfilled, as none of the other family members was willing to collaborate in the study. As a result, only the splicing variant was ranked as pathogenic according to $A C M G$, but not so the $c .2782 \mathrm{~A}>\mathrm{T}$ missense variant, which still must be classified as of unknown significance (Supplementary Table 3).

\section{Family FRP-621}

The proband from this family began to notice the typical RP symptoms in his twenties, but he was not clinically diagnosed until he was 31 old. In addition, he suffered from a mild sensorineural $\mathrm{HL}$ at high frequencies of adult onset. Variants c.3567delA (p.Gly1190Aspfs*39) and c.8779T >C (p.Cys2927Arg) in EYS (OMIM: 612424) were identified, which already are described as causative of ARRP (Audo et al. 2010, Pierrottet et al. 2014). Segregation analysis was confirmed, except for the youngest sibling (III:6), who initially was referred to as unaffected (Figure 1 ) and subsequently was determined to be carrier of both mutations.

No likely pathogenic variants explaining the HL were found.
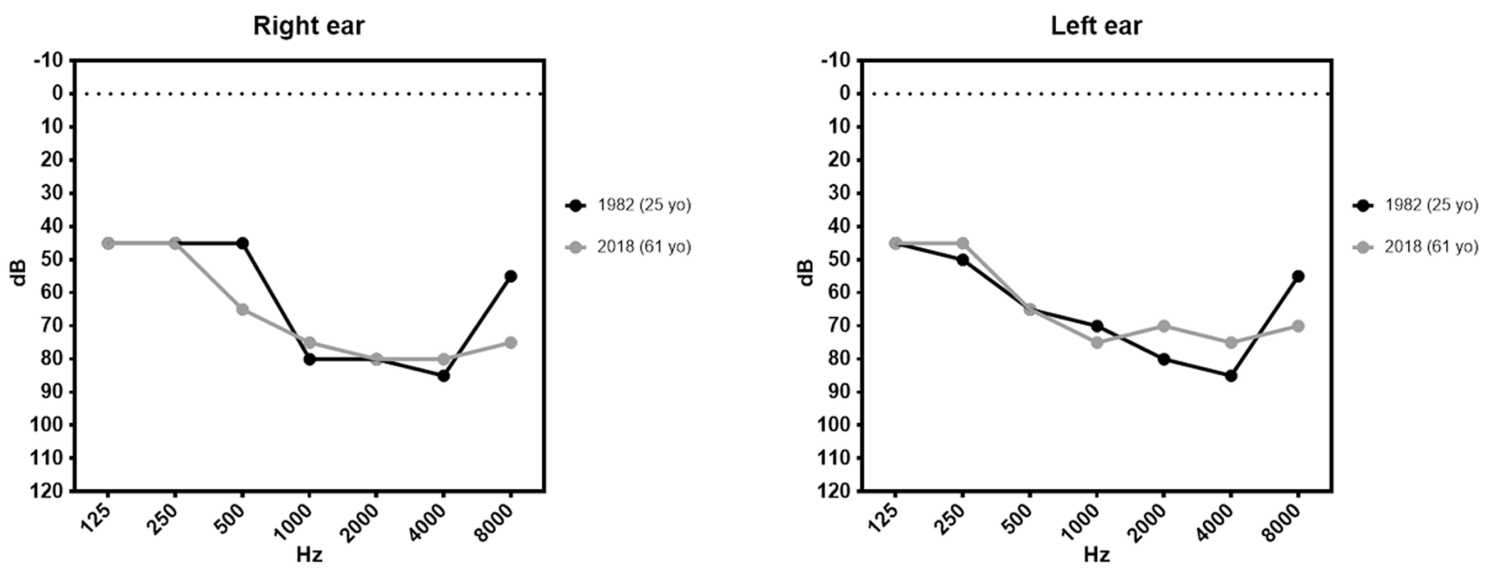

Figure 2. Audiograms from patient III:1 (FRP-426) at two different times. Results show a moderate-severe bilateral $\mathrm{HL}$ affecting all frequencies, that has remained stable in a 33-year time lapse. The audiograms present a " $U$ " shape, which is a distinctive pattern associated with the TECTA gene. yo, years old; $\mathrm{dB}$, decibels; $\mathrm{Hz}, \mathrm{Hertz}$. 


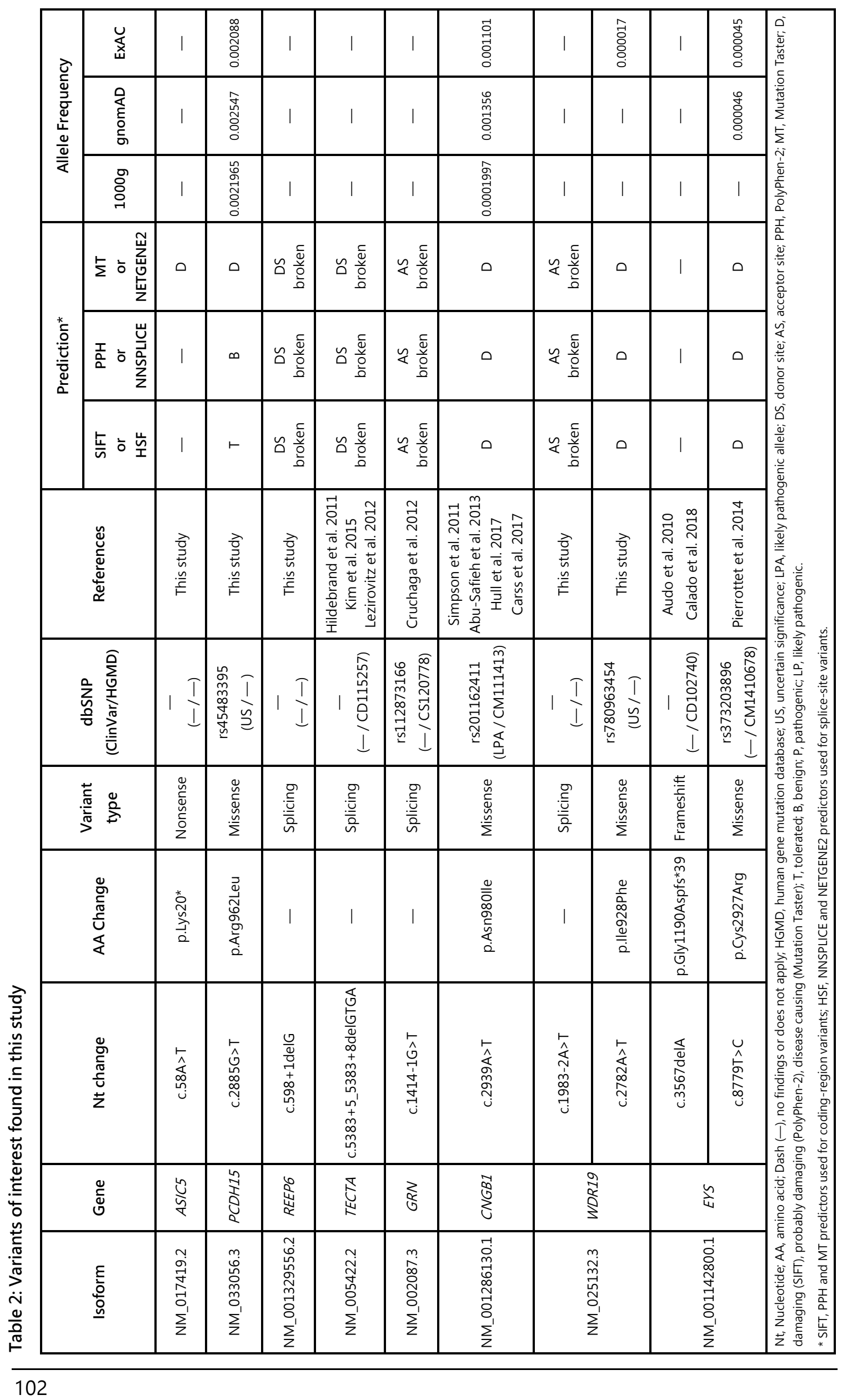




\section{Discussion}

\section{USH phenocopies}

\section{Family FRP-426}

For this case, the distinct genetic origins of the RP and $\mathrm{HL}$ have been ascertained by the mutations identified in REEP and TECTA. Regarding the latter, the dominant causality of the splicing variant may prompt a distrust, as the general train of thought is that missense variants in the gene are the ones responsible for this type of inheritance pattern, whereas truncating mutations are characteristic of a recessive trait. It should be noted that a synonymous and another splice-site variant in the same exon-intron boundary have been reported to likewise result in the skipping of exon 16 , in patients featuring a dominant $\mathrm{HL}$ phenotype (Collin et al. 2008, Hildebrand et al. 2011). The suppression of this exon, though, has been proved to maintain the reading frame (Lezirovitz et al. 2012). Therefore, the aforementioned changes actually stand as noninactivating TECTA mutations, consistently with the initial mainstream theory. In addition, $\mathrm{HL}$ due to mutations in TECTA display a distinct audiometric profile that matches the audiogram of the patient (Figure 2) (Naz et al. 2003).

These revelations supported the causative role of this variant for the deafness phenotype.

\section{Family FRP-621}

Regarding the apparent genotype-phenotype discrepancy of the one sib carrying both pathogenic mutations, the reason might be that, due to his young age, either the RP has not yet debuted or that he has unperceived inceptive symptoms. Unfortunately, he was not willing to undergo ophthalmologic evaluations, thus making it impossible to determine his genuine phenotype.

With respect to the genetically unsolved $\mathrm{HL}$, other possibilities must be contemplated. Considering the mild condition that only comprises the high-frequencies, it could be a case of presbycusis, which can begin as early as the third decade of life and for which a great number of risk factors, not only genetic, are at stake (Cech and Martin 2012). Indeed, the subject suffered from loud occupational noise exposure; therefore, the deafness in this case also could be noise-induced. 


\section{Partially misdiagnosed cases}

\section{Family FRP-480}

The c.1414-1G>T variant in the progranulin gene was detected in the sequenced patient of this family. Mutations in this gene generally are reported to cause FTD when presented in heterozygosis, and adult onset NCL if both alleles are compromised (Smith et al. 2012, Ward et al. 2017). The course of FTD includes cognitive and behavioral changes, whereas NCL is a more severe condition that usually involves additional neuropathological features, such as motor deterioration or epilepsy. Apart from the severe neurologic implications, a common symptom of NCL is retinal degeneration (Birch 1999, Smith et al. 2012, Ward et al. 2014), which matches the retinopathy presented in our index case, who manifested a severe RP-like phenotype that quickly ended up compromising her central vision as well.

The c.1414-1G>T mutation has been reported previously in the heterozygous state in a study where the subjects were first diagnosed with late-onset $A D$, though they were later reassessed by the authors as FTD cases due to the genetic findings (Cruchaga et al. 2012). The family presented in this study is reminiscent of those misdiagnoses, as it is not completely clear whether the symptomatic individuals suffer from either AD or FTD. Due to the molecular findings and symptoms of other relatives, we believe it to be FTD. Indeed, more cases have been reported to be inaccurately characterized with a posterior alternate diagnosis (Berkovic et al. 2016). Therefore, the boundaries between these diseases should not be strict, at least when progranulin is involved.

Taking into account the homozygosity of the variant, the proband manifested a rather mild phenotype when compared to other subjects with NCL carrying homozygous null mutations in the $G R N$, since the retinal and neurologic degeneration appeared in later stages. However, progranulin deficiency also has been repetitively associated with other related diseases, such as $A D$, amyotrophic lateral sclerosis, or corticobasal syndrome, depending on the allele dosage and type of mutation. Another study described a case of FTD with a mutation affecting the same splice-site domain, namely c.1414-2A $>G$ (Yu et al. 2010). Remarkably, the investigators of this work performed ex vivo splicing analysis of the variants and determined a pathogenic effect, yet the aberrant splicing process had only a partial effect. Thus, in vivo exon skipping due to homozygous mutations in that region could not be absolute in all cases; therefore, leading to a rather milder version of the phenotype. Not only has GRN a pleiotropic effect, but its age at onset is variable even within members of the same family (van Swieten and Heutink 2008), as occurs with the one presented herein. 
Other factors might be conditioning the appearance of the disease, and supporting this is the fact that some studies have nominated genetic modifiers (Wauters et al. 2017). In addition, the gene is estimated to have $90 \%$ penetrance by an advanced age, leaving a small amount of carriers possibly unaffected (Hsiung and Feldman 1993).

In brief, we believe that this particular mutation is responsible for standard FTD and, when both alleles are affected, for mild adult onset NCL.

Nonetheless, this assumption should be considered carefully, since most of the clinical information comes from a retrospective interrogation of the relatives which could not be precise. Unfortunately, because that this was an old family in which most of the members were deceased and some of the descendants were unwilling to participate, we could not perform a more extensive study that could have provided more insights.

As for the hearing impairment affecting two of the sibs, it seems that the feature segregates independently from the other presented symptoms. We did not find any likely causative variant, but, in view of the scarce clinical information, it could very well be due to presbycusis or other non-genetic factors. Even more, hearing deficits have been linked to patients with dementia (Gurgel et al. 2014, Hardy et al. 2016), so the progranulin deficiency also may be responsible for the $\mathrm{HL}$ in these cases.

\section{Family FRP-520}

Due to the lack of genetic findings regarding the hearing impairment in this family, further clinical inquiries were made. We discovered that the index case (II:3) had been misdiagnosed as having USH, since the proband did not suffer from sensorineural $\mathrm{HL}$, but rather from unilateral HL characterized as Meniere's syndrome, and the other affected brother did not manifest any hearing impairment at all. Therefore, this case was finally concluded as typical ARRP due to the aforementioned mutations in CNGB1.

\section{Family FRP-539}

The WDR19 gene has been reported as causative of a broad range of ciliopathies with $\mathrm{RP}$, such as nephronophthisis and Senior-Løken syndrome, but in the last years it has been associated with non-syndromic RP (Coussa et al. 2013, Fehrenbach et al. 2014). Again, no additional mutations explaining the $\mathrm{HL}$ were detected, neither in new nor in deafnessassociated genes. A new interview with the patient revealed that this was another misdiagnosed case, since the HL had been a self-diagnosed perception that was discarded after audiological examinations. The clinical reports of the patients and personal 
interrogation do not state any renal pathologies. For all these reasons, and cautious of the ACMG assessment of the missense variant, we considered this another putative solved case of non-syndromic ARRP caused by the compound heterozygous mutations in the WDR19 gene, which further supported the statements of previous studies of the gene being responsible for a wide phenotypic spectrum. In this way, there already was enough evidence to consider WDR19 not limited to nephropathy-associated IRDs, but also responsible for isolated RP.

\section{Unsolved cases}

\section{Family FRP-70}

The study proband presented a stop gained mutation in the gene encoding for protein member 5 of the acid-sensing ion channel family. Not a single homozygous loss-of-function (LoF) variant in that gene was present in the public databases from control subjects, suggesting that truncation of the protein probably has a visible pathogenic impact in the phenotype.

Acid-sensing ion channels (ASICS) are proteins that belong to the amiloride-sensitive $\mathrm{Na}+$ channel and degenerin ( $\mathrm{NaC} / \mathrm{DEG}$ ) family, comprising five paralogous genes (AS/C1, $A S / C 2, A S / C 3, A S / C 4$, and ASIC5)(Hanukoglu 2017). These genes are preserved among the chordate species and are expressed mainly in the central and peripheral nervous system (Cheng et al. 2018), being ASIC5 specific to a type of cells from the vestibulocerebellum and dorsal cochlear nucleus identified as unipolar brush cells, according to a gene reporter study in mice (Boiko et al. 2014). Previous studies in rodents showed expression of the gene predominantly in brain, liver, and intestine (Sakai et al. 1999, Schaefer et al. 2000). Those findings neither support nor contradict the pathogenic role insinuated in this study, since the molecular mechanism is yet unknown and it could be involved in several pathways. In fact, other USH genes also are expressed in the intestine and brain (Mathur and Yang 2015), as well as other ciliary tissues (Vaché et al. 2010).

It also is noteworthy that other genes of this family of proteins, particularly $A S / C 2$ and $A S / C 3$, have been found to contribute in retinal and auditory function in animal models (Ettaiche et al. 2004, 2009, Peng et al. 2004, Wu et al. 2009); thus, providing more hints of a possible equal role of $A S I C 5$.

Furthermore, ASICs also have been associated to mechanosensation and nociception (Cheng et al. 2018), in keeping with some other USH causative genes that have been proven to be involved in these processes (Frenzel et al. 2012, White et al. 2013). 
Apart from this truncating protein, a missense variant cosegregating in the family was detected and also should be contemplated (Table 2). The change c.2885G > T (p.Arg962Leu) in $P C D H 15$, a gene responsible for USH1, was detected in the homozygous state in the proband. However, this is a variant of uncertain significance, mostly predicted to be benign, and found in homozygosity in a control subject from the population databases. Moreover, conservation analyses (Supplementary Tables 1 and 2) suggest that this position is subject of considerable substitution rates. Therefore, we considered that this variant should be ruled out as the possible causative variant.

Due to the lack of more supporting data and despite the fact that no further convincing variants were found in the patient, we were unable to strictly propose the $A S / C 5$ gene as candidate for an USH-like phenotype at the present time. Nevertheless, it indeed could be responsible for the phenotype, and for that reason, we have highlighted this case to be of help to other present and future studies. We believe that it would be very interesting to test the functional role of this gene in an animal model, if more cases harboring mutations in $A S / C 5$ are found.

\section{Other unexplained cases}

Three additional cases in this study could not be solved, namely FRP-581, FRP-613, and FRP-616. Probably, the genetic cause of these cases may be either due to variants in regions not contemplated in this study, such as introns or UTRs, or because the mutations are located in still uncharacterized genes. Though most of the genes are labeled to date, there presently is little to no information for many of them, which makes it difficult to designate them as responsible for a certain disease, despite the availability of other parameters, such as conservation, expression, variant segregation, and so forth. A sensible approach for another attempt to molecularly diagnose these patients could be the performance of whole genome sequencing. With this method, not only the (supposedly) non-coding regions are contemplated, but also the read-depth remains steadier across the covered genome given that no capture step is needed. This enables the survey of other types of large rearrangements, such as translocations and inversions, and statistically more robust CNVs tests. However, the massive output of variants requires that other members of the family are included in the study to help in the search by allowing segregation filtering, and samples of the relatives are not always available. 


\section{Conclusions}

USH is the major disorder accounting for combined hearing and visual impairment, yet it is not the only one. Other disorders also manifest with similar features, such as Wolfram, Alström, Norrie, Heimler, Refsum, or PHARC syndromes, although they usually present with additional symptoms. Therefore, a rigorous evaluation of each case is needed, clinically and genetically, to establish better phenotype-genotype correlations. Cases FRP-520 and FRP539 , both being inaccurately diagnosed, evidence this need of a robust clinical evaluation before a genetic screening. It not only is essential for selection of the best application, such as targeted or whole exome sequencing, but also for an efficient data curation based on the symptoms. The proficiency of the diagnosis, however, depends greatly on the health care system and resources of each country. Retinal dystrophies and hearing loss are presented in multiple forms on their own; hence, they become harder to characterize when syndromic and prone to be misdiagnosed, especially if patients do not undergo exhaustive examination by specialists. We believe that an interdisciplinary medical diagnosis of patients manifesting at least one rare feature is key to understanding the molecular role of new and already known disease-associated genes. The GRN(FRP-480) gene also stands as a fair example for this, since it is mainly associated with FTD and NCL, but this and other previous studies have supplied cases that suggest it to be responsible of an array of neurologic disorders or disease continuum. It seems clear that mutations in the granulin precursor are involved in neurodegenerative diseases, but further genotype-phenotype associations, or research on disease modifiers and gene penetrance, should be conducted. Altogether, the findings in GRN and WDR19 attest the need to reevaluate the phenotypic spectrum caused, depending on the type and state of the mutations.

Despite RP having a low prevalence in the population, $\mathrm{HL}$ loss is not uncommon; therefore, the potential of uncovering an USH phenocopy must be kept in mind, as we showed with families FRP-426 and FRP-621. The latter lacks the molecular diagnosis for the $H L$, yet it remains unclear if the cause is genetic. Even so, hearing impairment is genetically extremely heterogeneous due to the variability of the causative elements and inheritance patterns known to date, making the diagnosis approach arduous.

Nevertheless, it must be remarked that results suggest that a greater than expected number of cases may be due to a combination of mutated genes concealed as an USH appearance. The outcome of this study proved that WES is a powerful tool to genetically decipher unsolved or misdiagnosed USH cases, and the several genetic scenarios have brought new insights into the mutational spectrum of Usher-like phenotypes. 


\section{Acknowledgements}

The authors thank the patients involved in this study and the associations Retina CV, FARPE, and Asociación Retina Asturias.

Supported by the Institute of Health Carlos III (ISCIII) and the European Development Regional Funds (Grants PI16/00539, PI16/ 00425), Fundación ONCE, by RAREGenomics, which is funded by Regional Government of Madrid (CAM; Grants B2017 and BMD37) and partially supported by FEDER (European Regional Development Fund), by a fellowship from the ISCIII and the European Social Fund (IFI14/00021; CFG), and by a senior postdoctoral contract from CIBERER (GGG).

\section{Authorship}

CFG, GGG, TJ, EA and JMM conceived and designed the study. CFG conducted the computational analysis, performed the molecular experiments and drafted the manuscript. FBK and CA referred patients, provided their samples and obtained their clinical data. LT performed the mapping and variant calling of the WES samples. $\mathrm{HH}$ coordinated the data processing and provided advice on the analysis. JMM and CA obtained the funding. GGG, TJ, EA, CA and JMM reviewed the results and the manuscript.

\section{Additional Information}

Supplementary information accompanies this paper at http://iovs.arvojournals.org/article.aspx?articleid=2755678 and in the Appendix section of the present dissertation document. 

GENERAL DISCUSSION 


\section{GENERAL DISCUSSION}

Usher syndrome is a rare disease and this trait makes it less prone to be researched to understand the underlying molecular mechanisms and to seek prospective cures. The concerned population being far smaller compared to other more common ailments, rare diseases are sometimes regarded as less relevant in terms of funding or the time spent researching. However, USH is not so forlorn, as many groups focus their investigation efforts on it and other related disorders, stepwise yielding many positive breakthroughs with regard to both the basic functional knowledge and translational advances.

The results of this doctoral thesis disclose the worthiness of exploring the new therapeutic approaches based on the prominent yet still-polemical genome editing nucleases towards a future precision medicine aimed to tackle the root of the disease. Since this goal is conditioned to the genotype, this dissertation also emphasizes on tracing the genetic cause of a sizeable group of Spanish Usher syndrome patients using a cost-effective HTS method, with the added purpose of implementing the procedure in the clinical practice foreseeing the periodical incoming of new cases. Furthermore, it contributes to the genetic intelligence of the disorder by molecularly diagnosing some complex cases with unusual mutations.

\section{Apropos the CRISPR-based edition approach}

The feasibility of correcting the most prevalent USH mutation, c.2299delG, in patientderived cells as proven in this work, represents a great leap forward in the disease field. However, this achievement is still a callow step in the scope of potential therapies, since the allelic repair rate in the assayed fibroblasts is too low to expect any real positive effect if directly applied to the retinal and cochlear cells of patients. The edition outcome must be improved before really considering the approach as a potential treatment option.

However, it must be remarked that neonatal dermal fibroblasts are considered to be one of the most unresponsive cells for transfection and edition (Lin et al. 2014a), and all the more if they are of adult origin. Therefore, they are not an exemplary model to hinge on. The mature photoreceptors and hair cells bear the non-dividing hallmark, the stakes being that the repair outcome would be at least as low as in fibroblasts. Yet again, the efficiency of gene editing in said cells via the CRISPR system remains unknown. If the proportion of geneticallyfixed cells came to be higher than expected, it might be sufficiently beneficial, even if it means preserving only a scant partial visual/hearing function. 
The in vivo studies targeting photoreceptors or hair cells in mouse models are actually conducted on cells that may conserve proliferation capacity even if they are claimed to be conducted at end-stages of the degeneration, because the assays are performed in the most early life stages of the animals that represent an accelerated course of disease model (Lamba et al. 2009, Singh et al. 2013, Santos-Ferreira et al. 2015, Gao et al. 2018, Collin et al. 2019). Therefore, they are not representative of the competence of the system in the real human adult tissues for which most therapeutic approaches are actually contemplated. It is true, though, that the success of these studies in developing tissues does not exclude a similar or more modest effectiveness in mature tissues. Besides, the onset of the hearing or visual impairment is prelingual in some diseases, and the results of these studies do apply in this context.

Nevertheless, given the potential of the CRISPR system, it has become the golden research field of the decade and there is an exponential number of groups working on its structure, mechanism of action, efficiency improvements, delivery options, and in vitro/in vivo applications, which altogether are yielding innovative progresses. Therefore, the same design here tested could be of major relevance in a near future if upgraded features of the system are used.

\section{Cas9 engineered modifications for increased on-target specificity}

The two most worrying issues in the community are the off-target risk and the NHEJ repair supremacy over the HDR pathway. Regarding the former, one of the major improvements of the CRISPR complex is the generation of "high-fidelity" versions of the Cas9 enzyme, reported to display less to null off-target activity while preserving on-target efficiency. Some of these first enzyme modifications, namely eSpCas9(1.1) or SpCas9-HF1 that are attributed to leaders in the field, were obtained by introducing mutations initially thought to weaken the polar forces at the recognition domain so that its attachment to the target DNA was restrained (Kleinstiver et al. 2016, Slaymaker et al. 2016). Yet this theory did not explain why the empirical reduction in the activity was constrained to the off-target regions instead of having an overall performance impact.

Later studies have unveiled the crux of the matter and it seems that those genetic changes rather lead to the arrestment of Cas9 in a cleavage-inactive sate if the heteroduplex formed by the guide RNA (gRNA) and the targeted DNA is not completely homologous. This quiescent configuration is only allosterically reversed into the active state if the hybridization is mismatch-free like the one offered by the on-target sequence (Chen et al. 2017, Dagdas 
et al. 2017, Singh et al. 2018a, Yang et al. 2018). Based on these observations, other rational modifications of these Cas9 subject to these dynamic conformational alterations, like HypaCas9, have been engineered to obtain finer versions of these unerring enzymes (Chen et al. 2017). Provided that these new endonucleases indeed ensure such a controlled checkpoint, the possibility to produce undesired off-targets is practically ruled out, making the oncoming genome editing trials safer.

Other forms of engineered Cas9 endonucleases are those in which the cleavage capacity is partially or completely depleted. Cas9 nickases (nCas9) are able to produce single-stranded breaks and the resulting one-side gaps are not repaired through the NHEJ but via the base excision repair pathway, thus resulting in fewer to no genomic scars (Jinek et al. 2012, Trevino and Zhang 2014). These maimed nucleases were initially used in pairs to produce DSBs with a reduced off-target risk, since non-target regions had to present homologous sequences for both constructions in the near vicinity (Ran et al. 2013a). The dual usage of site-specific nicking enzymes produces a staggered DSB with complementary overhangs. Despite the often subsequent end resection, a double-stranded cohesive fragment can be supplied to replace the region flanked by the two gRNAs, thus enabling knock-in via NHEJ-mediated DNA insertion (Ran et al. 2013a).

Lastly, the dead Cas9 (dCas9) is a completely disarmed version that only preserves the ability to attach to the specific DNA sequence (Qi et al. 2013). What appears to be a useless enzyme has in fact provided many useful possibilities. The mere binding to the DNA displaces the DNA strands and the resulting bulge, upon co-delivery with a ssDNA repair template, can induce slight HDR without the need of damaging the endogenous genomic sequence (Richardson et al. 2016). A therapeutic approach based on reiterative ministrations should be seriously considered, taking into account the drastic reduction of genetic collateral damages. Although, it must be kept in mind that plenty of independent doses would be needed to reach a minimum edition threshold, which could in turn be harming by themselves. This may be particularly hazardous in the eye, where subretinal injections are believed to produce adverse effects like retinal detachment, transient inflammation, photoreceptor damage or ocular hemorrhage (Becker et al. 2017, Peng et al. 2017).

Yet the applications of the dCas9 do not end here. Other approaches have taken leverage of this simple approximation ability to direct other compounds to a specific genomic locus. For instance, it can be used to change methylation patterns or for nucleotide conversion using the novel base-editing approaches that enable this type of genomic editing thanks to the enzymes attached to the complex (Rees and Liu 2018, Xie et al. 2018). 
The latter example is unfortunately limited to some point mutations, but the large assortment of missense pathogenic variants responsible for USH warrants many suitable candidates for this modality.

Depending on the nature of the variant, different types of these Cas9 options should be explored.

\section{The matter of NHEJ offshoots and predominance over HDR}

The other major drawback of the CRISPR system is that the NHEJ process surpasses the HDR rate. For in vivo procedures, this entails a great inconvenience, for successfully edited subpopulations cannot be enriched or selected, even less so in postmitotic cells. The resulting problem does not so much lie in the mutations produced by this error-prone repair mechanism, at least for recessive diseases like USH, because they would not damage the cells given that all alleles already carry pathogenic variants compromising the protein function. Instead, the bigger issue concerns the locus alteration amidst that proportion of cleaved cells, which would hamper further recognition by the gRNA and thereby deter the option of performing recurrent assays to meet a cumulative suitable correction rate.

It must be said, too, that the indels produced by the NHEJ repair pathway, which initially were thought to be a random process, are actually dependent on the immediate surrounding genomic sequence, and prediction of these mutational byproducts is possible to some extent using machine-learning algorithms (van Overbeek et al. 2016, Shen et al. 2018, Allen et al. 2019, Chakrabarti et al. 2019). This insight is not only useful to predict the resulting heterogeneous indel distribution, and thus the most probable functional impact, but also to have another template-free option at disposal to generate deliberate changes (Shen et al. 2018). Still, this proposed edition method based on NHEJ-derived mutation prediction is not suitable for any locus, given that the range of possible uncontrolled modifications is conditioned to the region, and it is thus only compatible for a limited set of mutations. Frameshift variants would be the main susceptible niche, due to the fact that the most prevalent type of lesion engendered after NHEJ are small indels, which might stand a chance of rebuilding the reading frame.

\section{$\underline{\text { Towards knock-in enhancement }}$}

In any case, there are many efforts focused on improving the HDR efficiency or decreasing the NHEJ frequency in order to enhance the HDR:indel ratio, either based in the 
CRISPR substrates (like the already commented template modifications) or in secondary operators involved in favoring the different repair mechanisms.

Some approaches revolve around NHEJ-inhibition to tip the balance in favor of the HDR, such as the suppression of the key enzymes Ku70, Ku80, DNA Ligase IV or the DNAPKcs (Chu et al. 2015, Maruyama et al. 2015, Robert et al. 2015), or the expression alteration of modulators like p53 binding protein 1 or Rad52 (Paulsen et al. 2017, Canny et al. 2018). In parallel, other strategies aim to directly boost the HDR, for example through supplementation of HR-stimulating small molecules (like RS-1, L755507 or Brefeldin A) (Jayathilaka et al. 2008, Pinder et al. 2015, Yu et al. 2015, Song et al. 2016). However, some genomic regions may still require the NHEJ repair pathway and the indiscriminate discharge of either of these types of compounds could lead to unpredicted side effects.

Accordingly, site-specific biasing of the repair mechanism premised on compound approximation has been lately explored, bringing forth astute tactics based on the fusion of the Cas9/gRNA complex with other molecules. There is the Cas9/RecA system, where the complex is linked to the bacterial recombinase $A(\operatorname{Rec} A)$ known to enhance mammalian HR (Lin et al. 2017, Cai et al. 2019); the covalent tethering of the ssODN to facilitate the access to the template right after the DSB (Aird et al. 2018); fusion of either Cas9 or dCas9 with CtIP, an HR-inducing protein key in the end resection process (Liu et al. 2019); or the hRad51Cas9 nickase, with the usage of the semi-ablated enzyme producing a single-stranded cut linked to mutant dormant versions of Rad51 (Rees et al. 2019).

Regarding Rad51, which is the human homolog of the RecA, intense research has been conducted due to its involvement in the cellular repair mechanisms through homologous recombination. Though there has been some controversy about the exact action of the protein, a recent breakthrough study (though not yet peer-reviewed) has unveiled that Rad51 rather promotes the interhomolog repair, a so-to-say homozygosity converser, instead of increasing the overall knock-in efficiency (Wilde et al. 2018). The protein, which forms nucleofilaments that aid in the repair template recruitment by promoting strand invasion, is essential for the canonical HR pathway occurring during cell division and it is also activated upon the aggressive incidental DSBs to increase the chances of a proper sequence restitution (Mazina and Mazin 2004, Heyer et al. 2010, Davis and Maizels 2014, Wilde et al. 2018). At the same time, though, it prevents recombinogenic events when milder damages in form of nicks happen, in order to preserve genomic stability by favoring the more reliable and simple gap-ligation repair pathway (Davis and Maizels 2016). Consequently, a promising option to obtain higher knock-in frequencies without risking (or at least 
minimizing) the undesired NHEJ events is the inhibition of this cardinal protein in combination with usage of the less-injurious Cas9 nickase (nCas9) (Rees et al. 2019). Moreover, the mere creation of an allele-specific DSB might prove to be a valid templatefree method to correct heterozygous mutations, by prompting the recombination of the targeted region with the healthy locus of the other chromosome.

An easy mistake is considering that HR-mediated repair is driven by the same mechanisms as meiotic recombination. Another fresh work release has exposed that the single-stranded template repair is dependent on the Fanconi anemia pathway, auguring further global research on the mechanism to take leverage of key factors promoting the recombination efficiency (Richardson et al. 2018).

These are only some examples of the exponentially-arising advances in the race to find safer and more efficient modifications of the CRISPR system, which sooner or later will surely provide the scientific community with the proper tools to take more daring steps in the edition of the human genome as a treatment option.

\section{Reaching the target organ}

Even if any of these CRISPR optimizations turned to be befitting to treat USH, or any other disease, there are other issues raised in the last years that attempt to hamper their translation into clinics.

The first one is the delivery method, since some of the methods that have rendered good results in in vitro assays, or in in vivo experiments at embryonic stages, are not suitable for the full-developed adult tissues. To date, the use of viral carriers constitutes the most sensible proceeding, because they have been already approved for other human gene therapy approaches in several organs (including the retina). However, this approach is limited to the delivery of nucleic acids, ruling out the use of some of the above mentioned system refinements that differ in the format presentation of the components.

Some of the usual lipofection mediums, and procedures based in electroporation, are not appropriate because of their toxicity. There are some similar alternatives of these encapsulating carriers currently under research, which allow varied types of cargo, such as niosomes, cell-penetrating peptides, bacterial pore-forming toxins, or inorganic nanoparticles (Mout et al. 2017, Lino et al. 2018, Grijalvo et al. 2019). Even though the majority still lack the approval for human use, the safety and biocompatibility of many will probably be demonstrated in the upcoming years, widening the spectrum of delivery options. 
Strikingly, some groups perform in vivo retinal electroporation supposedly without major damage to the tissue and allowing the entry of the compounds, yet again, mostly on development stages (Matsuda and Cepko 2004, Nickerson et al. 2014, Latella et al. 2016, de Melo and Blackshaw 2018, Vagni et al. 2019). Fewer equivalent studies of this membrane permeabilization method in the inner ear can be found (Brigande et al. 2009, Wang et al. 2012). This practice is instinctively perceived as an aggressive method, and the available studies do not help to dispel the doubts, as no detailed assessment of the damage is procured. Still, if the technique proves to be not as invasive as the rational thinking prompts, it would proffer an easy enough option for naked delivery of CRISPR compounds, a significant gain for the field of delivery. Further studies on the matter are therefore very interesting.

\section{Cas9 human immunogenicity}

Setting aside the delivery issues, not long ago a study revealed that more than half the population presents antibodies against Cas9 (Charlesworth et al. 2019). This means that even if efficiently delivered to the organ, in many patients the CRISPR compounds might be invalidated through the immune system or induce the counter-productive apoptosis of the edition-targeted cells. Luckily, though, the eye is an immune-privileged organ, since it is quite isolated from the general immunologic processes, giving an advantage for the use of otherwise potential antigenic molecules in it. Omitting this tolerogenic feature of this organ in question, it is important to note that despite the general fuss that followed the disclosures about the CRISPR immunogenicity, the case might not be as grave as initially thought to be. In the original publication, the only immunologic response for the wild type Cas9 coming from Streptococcus pyogenes was detected for the humoral mechanism, all the tested individuals lacking anti-Cas9 T-cells. Given that there seems to be no cellular immunity to the protein, the CRISPR compounds should not be necessarily blocked as long as they remain shut off from the extracellular environment (Crudele and Chamberlain 2018). Thereon, in vivo trials shall be designed to assure there are no free-circulating Cas9 proteins, but preferably inside coated systems or intracellularly secluded. This being said, a couple of recent studies partly refute the absence of T-cells-mediated response (Ferdosi et al. 2019, Wagner et al. 2019). Thus, the immunologic topic still needs to be fully elucidated.

In any case, the problem might be circumvented through other strategies. For shortterm exposures to Cas9, patient could undergo transient immune-suppression, a widespread clinical practice used previous to another (or as a direct) treatment, including 
AAV gene therapy. Furthermore, epitopes could be eliminated by introducing neutrally functional missense mutations, if they are not already cleared in the above mentioned Cas 9 mutant versions (Ferdosi et al. 2019).

Regardless of the immunologic threat, ex vivo assays stand as another possible solution. As commented in the introductory section of this dissertation, a therapeutic approach for retinal diseases that is being clinically assessed is the restocking of the light-sensitive cells. Some limitations must still be addressed, such as correct maturation, organization and the polarization of the grafted photoreceptors, as well as other factors involving the recipient tissue, like the tumorigenicity when using cells retaining some pluripotency, or the aberrant synaptogenesis and retinal gliosis that offshoots in many degenerated retinas at advanced stages (Singh et al. 2018b, Gagliardi et al. 2019). In addition, the cell replacement strategy (for both RP and SNHL) still deals with two additional challenges. First, if the method is in reliance on allotransplantation there might still be some immunologic rejection even in the retina, despite the eye being immune-privileged. Otherwise, if the procedure is founded on autologous transplantation, the substitute cells would still carry the genetic defects eventually leading to the same fate as the original cells. This is where the CRISPR technology comes into play. With the new gene editing tools that are being improved every year, the latter issue might be bypassed by an ex vivo mutation correction step prior to the transplantation. Nevertheless, we will need to wait to assess the function-related results of the clinical trials with unmodified transplanted cells.

Altogether, the CRISPR system seems to be a potential therapeutic field to treat genetic diseases, especially those concerning retinal disorders. Moreover, the technology has also propelled the basic research field, which also renders discoveries that eventually will end up being medically beneficial. Setting aside the current existing USH animal models and those going to come more easily thanks to these tools, the current possibility to obtain human retinal organoids offers the chance to assay the CRISPR approaches in in vitro models that resemble a bit more to the retinal tissue. Moreover, the CRISPR system offers the possibility to perform disease modeling on these 3D cups. In this regard, organoids with patientspecific genetic background with and without a corrected disease-causing mutation can be generated, in order to study the pathogenic molecular mechanism derived from the variant or even to ascertain if a dubious mutation indeed elicits a pathogenic effect (Nie and Hashino 2017, Deng et al. 2018). 


\section{On the subject of the HTS venture}

The use of HTS in the last decade has evolved from being an exclusive procedure to almost a routine practice for addressing various problems.

Concerning the second-generation sequencing options, Illumina and Ion Torrent have overthrown the rest and are the current platforms used for HTS, though the former practically monopolizes the field. As a general overview and regardless of the inherent instrumental workflow, Illumina and Ion Torrent present several main differences. First, Illumina reads are the same length, whereas in lon Torrent reads have variable length (within a range) due to the flow order of the nucleotides. Ion Torrent presents both a faster library preparation and run time, yet Illumina has a higher output capacity and for this reason it is the broadly used system for WES and WGS (Quail et al. 2012). Another feature is that Illumina uses capture protocols for the selection of the regions, whilst lon Torrent relies directly on amplification for target selection and enrichment, which enables sequencing of samples of lower quality, but at the same time it is more biased on the coverage and hampers large rearrangement analyses. It appears also that the instruments and runs are usually less expensive in lon Torrent system, especially when a large cohort is used for the same design, which might be of use for systematic clinical diagnosis (Liu et al. 2012, Loman et al. 2012).

It must be noted that, since Illumina has been the dominant sequencing platform throughout these years, most of the read processing tools have been developed for this system. The fact that there are scarce platform-specific algorithms probably has undermined mapping and variant calling results for other systems like Ion Torrent, which may prove better otherwise.

Aside from that, HTS tosses a great number of variants, whose functional impact must be gauged to find the genetic cause of a disease. Considering that WES of one sample, for instance, yields around 100,000 variants, the data filtering proves to be a challenging endeavor. Manually dealing with each of the variants is inconceivable and the task must rather be computationally operated. Consequently, the Bioinformatics sector has thrived on this necessity, and it is currently indispensable for many applications in Biology. There are several algorithms and pipelines that are pivotal to obtain correct results and that are constantly being optimized and recreated.

Many of these determinant factors are intrinsic to the computational domain, such as the functional/conformational prediction softwares or the read-aligning algorithms. However, the starting material from which this field nourishes has a direct repercussion on 
the final outcome as well, and it also goes through continual evolution. Since the complete human genetic code cracking back in 2001 there have been several versions of the reference genome as it was refined in accordance with every new batch of sequenced genomes. Even the most mature GRCh38 release is still sketchy despite the full sequence itself being known, because the genome is not fully assembled due to the short-fragment sequencing process. Thus, there are some so called contigs that consist in regions without an assigned position or orientation along the genome, which are then allocated to a genome patch that can be more dynamically updated without altering the order of the main genome sequence.

In addition, the ever-growing number of sequenced genomes of (supposedly) healthy individuals, that enables the variant frequency determination collected in the several demographic databases, is fundamental to dismiss the polymorphisms from the set of candidate variants. Similarly, the cataloguing of disease-correlated mutations sometimes allows the quick identification of disease-causing variants. On this subject, not only the human genomic knowledge is informative, but the DNA composition of other species also offers important insights, since the conservation scores of amino acids or whole proteins are based on the sequence preservation across organisms.

For all these reasons, it is recommendable to perform periodic reanalyses of unsolved samples from the very beginning using the newest knowledge on variants and the revised computational tools (Wright et al. 2018).

\section{The enigma of the USH unsolved cases}

Despite the refinement of the sequencing approaches, the genetic cause of some USH cases, from this and other works, has yet to be elucidated. The pathogenic variant might have been missed because of the shortage of the bioinformatics algorithms employed or due to errors at the sequencing step itself. However, there are many other reasons that could be likely responsible, such as the existence of yet-uncharacterized USH genes or the implication of less studied loci like UTRs or intronic regions in the known disease-causative genes. The latter assumption is supported by the fact that several cases have been partially solved by the detection of only one of the damaging variants, without a trace of the second amidst the examined regions. Indeed, at the outset of the TES study herein presented, only the c.7595-2144A> G deep-intronic mutation in USH2A was known, yet four additional ones in the same gene and another in CLRN1 were revealed shortly after (Liquori et al. 2016, Baux et al. 2017, Khan et al. 2017). 
Moreover, some of the variants might have been prematurely casted aside based on a presumed neutrality, such as synonymous mutations or benign-predicted missense changes. Aside from their effect upon the reading frame, certain exonic variants can be part of splice-recognition motifs or exonic splicing enhancers (ESEs), their alteration having pathological consequences. In addition, in view of the fact that the USH transcriptomic set of the known genes is still not completely ascertained, some of these discarded elements could prove to have a truncating impact with respect to another isoform, sufficing to produce the pathogenic phenotype.

Either way, the interpretation of the damage degree of novel missense variants is also a challenging issue. There are many in silico programs that establish a pathogenic score for variants of unknown significance (VUS), based on biochemical properties and conservation criteria. However, these evaluations are mere predictions and sometimes further functional studies, which are time-consuming, are required.

The computation prediction of the three-dimensional skeletal configuration of the protein, and consequently the mayhap structural alterations due to amino acid chances, would also be a very enlightening resource. However, this Omics domain is yet struggling to obtain accurate and timely efficient algorithms. Most of the current ratified protein structures have been somehow experimentally confirmed with X-ray crystallography or nuclear magnetic resonance spectroscopy measurements. Or, alternatively, using other similar proteins as a starting point, a method known as template-based modeling (Lee et al. 2009). The challenge resides in the ab initio protein structure prediction, which is the calculation of the protein folding framework from scratch (Delarue and Koehl 2018). Hopefully, though, considering how rapidly the computational field is progressing, we may have reliable algorithms available before long that will enable solid appraisals of missense variants.

In any case, more extensive studies in those USH cases, including whole genome survey, should be conducted in order to increase the molecular knowledge of the disease.

\section{The importance of an accurate clinical assessment}

The expansion of the covered area, though, can also lead to unexpected outcomes. From the nine families studied through WES, two of the screened families (FRP-520 and FRP539) were finally exposed as clinical misdiagnoses, since the $\mathrm{HL}$ in the patients was wrongly assessed. In addition, a different one resulted to be an unequivocal USH phenocopy (FRP426), and another two presumably share the same status (FRP-480 and FRP-621) that cannot 
be confirmed for the moment in regards to the lack of identified pathogenic variants explaining the HL. Had the four most evident non-USH families (FRP-426, FRP-480, FRP-520 and FRP-539) been initially thoroughly evaluated, they would not have been considered for the TES cohort and the molecular diagnosis rate would have been significantly higher. It must be taken in that the genetic diagnosis is not an alternative to the clinical assessment, but a synergistic resource towards the case characterization. Thus, it is important to emphasize again the importance of an accurate phenotypic evaluation of the patients.

\section{Reconsidering past and future USH genetic disclosures}

On the other hand, the phenocopy cases lead to wonder about the number of unsolved cases from other works that, instead of being caused by mutations in new USH genes yet to be uncovered, might rather be similar cases of concomitance of two allelic gene sets producing the deafblindness phenotype. Furthermore, the displayed findings may even raise the doubts as to the genuine causality of certain USH genes, as it is the case of CIB2. Since the original published association, the gene has not been reported to be responsible for any other USH case, but meanwhile correlated to HL in several other studies (Giese et al. 2017, Michel et al. 2017, Wang et al. 2017). Suspiciously so, mutations in this gene might only account for the hearing impairment (Booth et al. 2018), meaning that the affected members of that family could actually represent other phenocopy cases of the disease with the visual impairment being caused by mutations in any of the many other nsRP genes. This said, the study provided robust data on CIB2 implication in both the hair cells and photoreceptors consistent with a role in $\mathrm{Ca}^{2+}$ homeostasis, thus, mutations in the gene must still be heeded as a cause of USH.

The arrival of HTS has simplified the tracking of disease-causing genes by enabling an easy and affordable method to directly survey the molecular foundations of any person. However, in return, it has exposed the vast amount of genomic variation, which by itself is the major challenge upon narrowing down the search for the hunted gene. To date, the association of a gene to a certain disorder is only accepted after the sequencing screening results are reaffirmed by further functional validations and similar independent cases. The previous methods to pinpoint a gene took more time and effort, something that could have fallaciously warranted the robustness of the results. Viewed from the current perspective, it leads to wonder whether the limitations of those techniques could have sometimes caused the inadvertence of relevant variants and, thereby, the hasty designation of a gene. 
Concerning the Genomics field, this is an era defined by the massive data production, although most of the output has an uncertain significance and sharing the knowledge should be mandatory to aid in its interpretation. In this regard, not only the peer-reviewed works are important, but also the intergroup information sharing. Given that some findings are not deemed satisfactory enough to be published, the direct query amidst the research collective enhances collaboration opportunities that will speed up the process of gene discovery. Several web-based platforms or disease consortiums with this cooperative purpose are already in use, such as the Matchmaker Exchange (Philippakis et al. 2015) or the more specific to the field European Retinal Disease Consortium (ERDC, www.erdc.info), that will become more and more profitable as this practice gets standardized within the gene diagnosis community. 


CONCLUSIONS 


\section{CONCLUSIONS}

1 The CRISPR model developed in the present work, based on gRNA-1 leading sequence, is an effective design to precisely target exon 13 of the USH2A gene with at least $6 \%$ site-specific cleavage rate in patient-derived fibroblasts and without off-target activity.

2 The USH2A gene editing approach based on the gRNA-1/Cas9 complex delivery and the endogenous repair mechanism is a valid method to invitrously correct the prevalent c.2299delG pathogenic variant, yet the limited 2.5\% knock-in efficiency exposes adult patient-derived dermal fibroblasts as a low respondent cell type.

3 The targeted gene panel produced in this work for the ion sensing high-throughput sequencing platform is a sound method for the molecular diagnosis of Usher syndrome patients, since $82.8 \%$ of the expected pathogenic alleles were detected in a cohort of 58 previously unscreened cases.

4 The amplification capture strategy here used does not allow the detection of large rearrangements due to the read-depth variability throughout the covered regions, and the contingency of such aberrations must be inspected through complementary techniques.

5 A substantial proportion of the variants causing Usher syndrome are private, given that almost half of the pathogenic variants identified in the study (42 out of 96) have not been previously described. 
6 Mutations in the CEP250 gene can cause a non-USH deafblindness phenotype, in which the vision impairment is a consequence of a cone-rod dystrophy.

7 WES allows the identification of USH phenocopies: two individuals in the studied set of patients by whole exome sequencing were not USH cases but actually phenocopies of the disease, being the cause of the hearing loss and the retinitis pigmentosa of independent origin.

8 A robust clinical appraisal of the patient and a proper familiar anamensis preceding the molecular study is essential to efficiently achieve an accurate genetic diagnosis. Three of the TES-negative cases of this work were ultimately exposed as misdiagnosis of Usher syndrome after the WES survey, as the hearing impairment had been wrongly assessed for two of them and the third showed a more complex phenotype.

9 The findings of the present study provide further evidence that mutations in the genes WDR19 and GRN are responsible for a wider disease spectrum than the usually associated phenotypes.

10 The detected stopgain mutation in $A S / C 5$ identified in this study is not enough to postulate the latter as a candidate gene for either hearing loss, retinal degeneration, or the combination of both symptoms. Nonetheless, the evidences provided in this and other works indicate that the gene is at least worth heeding in the context of said symptoms. 

APPENDIX 


\section{APPENDIX}

\section{Supplementary information appertaining Chapter II}

a

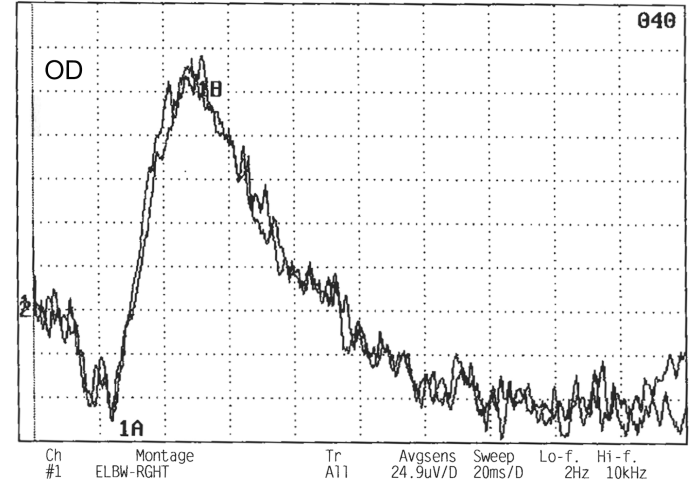

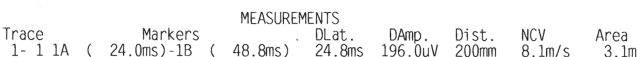

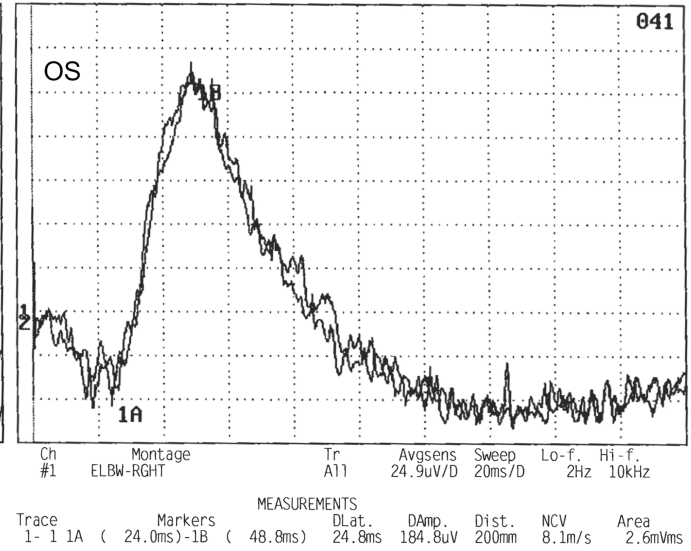

b
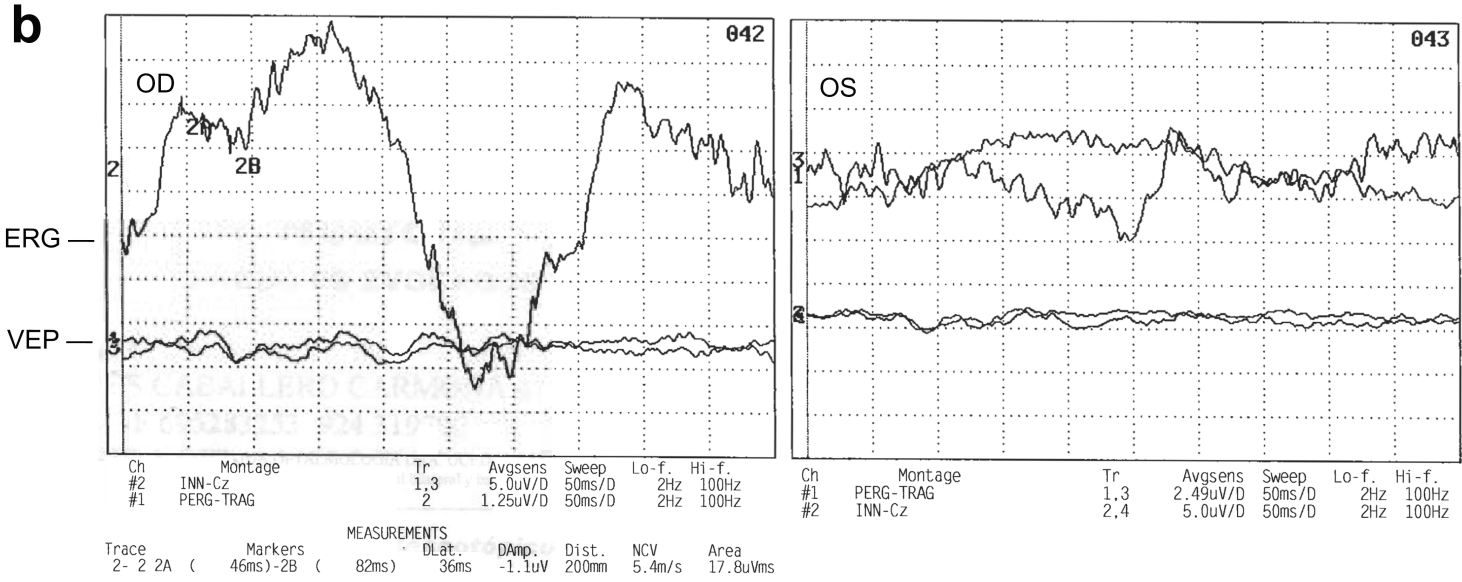

OS

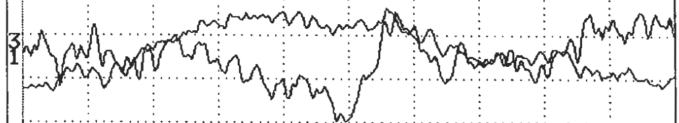

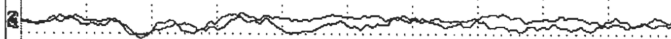

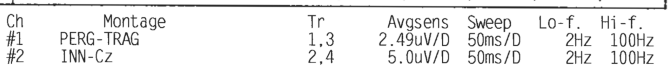

Supplementary Figure 1. ERG results. (a) Only light alterations are seen in dark adapted at $3 \mathrm{~cd}$ (cone and rod mixed response). (b) In the macular light adapted, the alterations are more severe, affecting also the VEPs. Abbreviations: $O D$, right eye; $O S$, left eye. 
a

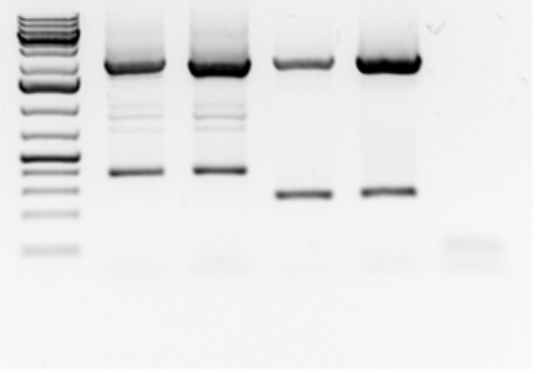

C

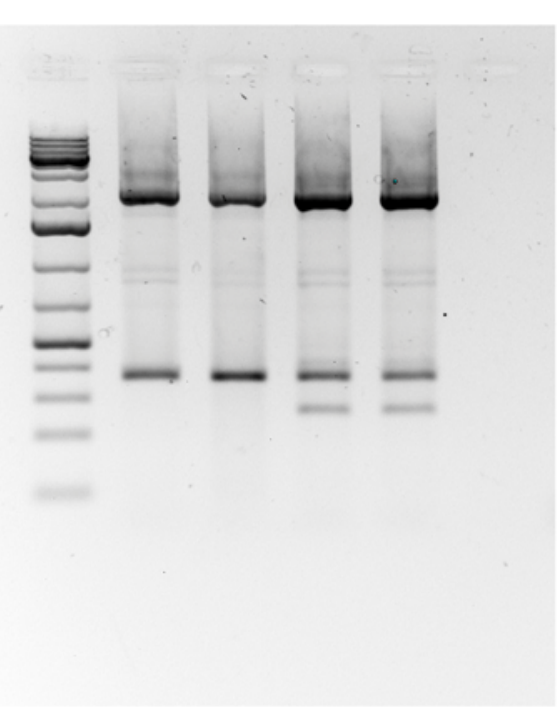

b

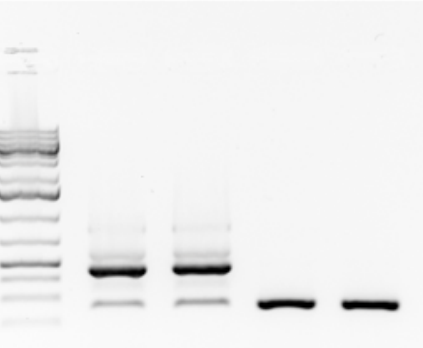

d

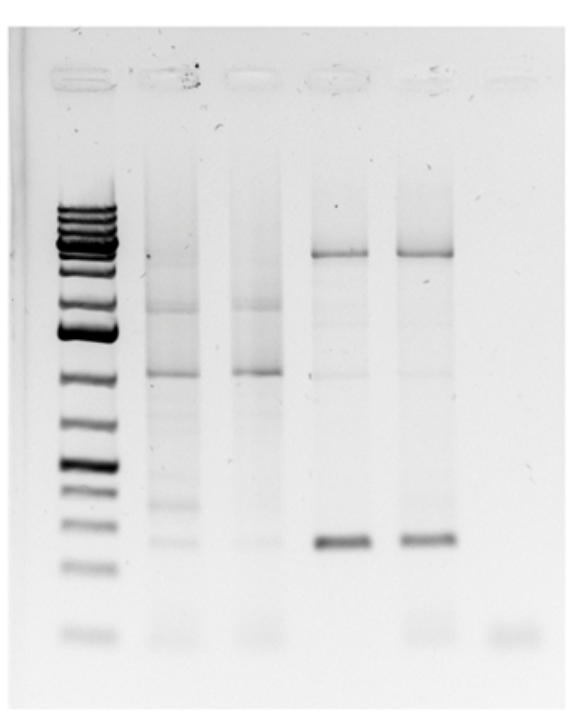

Supplementary Figure 2. Full-length gels from Figure 2. Gel corresponding to the minigene assay for the (a) c.53145T>A mutation (ADGRV1), (b) c.5776+1G>A mutation (USH2A), (c) c.1691-1G>A mutation (MYO7A), (d) c.12295$1 \mathrm{G}>\mathrm{A}$ mutation (USH2A). 


\section{Supplementary information appertaining Chapter III}

Supplementary Table 1: Assessment of the missense variants using conservation algorithms

\begin{tabular}{|c|c|c|c|c|c|}
\hline \multirow{2}{*}{ Gene } & \multirow{2}{*}{ Nucleotide change } & \multirow{2}{*}{ Amino acid change } & \multicolumn{3}{|c|}{$\begin{array}{c}\text { Conservation scores* } \\
{\text { (Deleteriousness interpretation })^{\dagger}}^{\dagger}\end{array}$} \\
\hline & & & GERP ++ & PhyloP & SiPhy \\
\hline PCDH15 & c. $2885 G>T$ & p.Arg962Leu & $\begin{array}{c}1.68 \\
\text { (Neutral) }\end{array}$ & $\begin{array}{c}0.548 \\
\text { (Neutral) }\end{array}$ & $\begin{array}{c}9.078 \\
\text { (Neutral) }\end{array}$ \\
\hline$C N G B 1$ & c.2939A > T & p.Asn980lle & $\begin{array}{c}5.2 \\
\text { (Deleterious) }\end{array}$ & $\begin{array}{c}1.968 \\
\text { (Deleterious) }\end{array}$ & $\begin{array}{c}8.876 \\
\text { (Neutral) }\end{array}$ \\
\hline WDR19 & c. $2782 \mathrm{~A}>\mathrm{T}$ & p.lle928Phe & $\begin{array}{l}5.49 \\
\text { (Deleterious) }\end{array}$ & $\begin{array}{c}2.075 \\
\text { (Deleterious) }\end{array}$ & $\begin{array}{l}15.595 \\
\text { (Deleterious) }\end{array}$ \\
\hline EYS & c.8779T>C & p.Cys2927Arg & $\begin{array}{c}5.08 \\
\text { (Deleterious) }\end{array}$ & $\begin{array}{c}1.920 \\
\text { (Deleterious) }\end{array}$ & $\begin{array}{c}13.438 \\
\text { (Deleterious) }\end{array}$ \\
\hline \multicolumn{6}{|c|}{$\begin{array}{l}\text { * The larger the score, the more conserved. Score ranges: GERP }++ \text { from }-12.36 \text { to } 6.18 \text {; PhyloP from }-14 \text { to } 3 \text {; SiPhy from } 0 \text { to } \\
37.9718 \text {. } \\
{ }^{+} \text {According to Dong et al. (2015) deleterious thresholds are }>4.4 \text { for GERP }++,>1.6 \text { for PhyloP, }>12.17 \text { for SiPhy. }\end{array}$} \\
\hline
\end{tabular}


Supplementary Table 2: Alignments and conservation across different species for the amino acid changes

\begin{tabular}{|c|c|c|c|c|c|c|c|c|c|c|c|c|c|c|c|c|c|c|c|c|c|c|c|c|c|c|}
\hline \multicolumn{27}{|c|}{ PCDH15： p.Arg962Leu } \\
\hline Human & $E$ & $\mathrm{~F}$ & $I$ & S & A & $\mathrm{P}$ & Y & $\mathrm{P}$ & $\mathrm{F}$ & Q & $\mathrm{V}$ & D & $\mathrm{D}$ & $\mathrm{V}$ & $\mathrm{R}$ & Y & $\mathrm{R}$ & $\mathrm{V}$ & $\mathbf{R}$ & S & $\mathrm{A}$ & $\mathrm{P}$ & L & G & \multirow{2}{*}{\multicolumn{2}{|c|}{ intron }} \\
\hline Chimp & $\mathrm{D}$ & $\mathrm{F}$ & I & S & A & $\mathrm{P}$ & Y & $\mathrm{P}$ & $\mathrm{F}$ & $Q$ & $\mathrm{~V}$ & $\mathrm{D}$ & $\mathrm{D}$ & $\mathrm{V}$ & $\mathrm{R}$ & Y & $\mathrm{R}$ & $\mathrm{V}$ & $\mathbf{R}$ & S & A & $\mathrm{P}$ & $\mathrm{L}$ & G & \multirow{2}{*}{\multicolumn{2}{|c|}{$\begin{array}{l}\text { intron } \\
\text { intron }\end{array}$}} \\
\hline Rhesus & $\mathrm{D}$ & $\mathrm{F}$ & I & S & A & $\mathrm{P}$ & Y & $\mathrm{P}$ & $\mathrm{F}$ & Q & $\mathrm{V}$ & $\mathrm{D}$ & $\mathrm{D}$ & $\mathrm{V}$ & $\mathrm{R}$ & Y & $\mathrm{R}$ & V & $\mathbf{R}$ & S & A & $\mathrm{P}$ & L & G & & \\
\hline Mouse & D & $\mathrm{F}$ & I & S & A & $\mathrm{P}$ & $\mathrm{Y}$ & $\mathrm{P}$ & $\mathrm{F}$ & $Q$ & V & D & D & V & $\mathrm{R}$ & $Y$ & $\mathrm{R}$ & V & $\mathbf{R}$ & S & A & $\mathrm{P}$ & M & G & \multicolumn{2}{|c|}{ intron } \\
\hline Rabbit & D & $\mathrm{F}$ & I & S & A & $P$ & $\mathrm{Y}$ & $\mathrm{P}$ & $\mathrm{F}$ & $Q$ & $\mathrm{~V}$ & D & $\mathrm{D}$ & V & $\mathrm{R}$ & $Y$ & $\mathrm{R}$ & $\mathrm{V}$ & $\mathbf{R}$ & S & A & $\mathrm{P}$ & $\mathrm{L}$ & G & \multicolumn{2}{|c|}{ intron } \\
\hline Pig & D & $\mathrm{F}$ & I & S & A & $\mathrm{P}$ & Y & $\mathrm{P}$ & $\mathrm{F}$ & $Q$ & I & D & D & V & $\mathrm{R}$ & Y & $\mathrm{R}$ & V & $\mathbf{R}$ & S & A & $\mathrm{P}$ & L & G & \multicolumn{2}{|c|}{ intron } \\
\hline Elephant & D & $\mathrm{F}$ & I & S & A & $P$ & $Y$ & $\mathrm{P}$ & $\mathrm{F}$ & $Q$ & V & D & D & V & $\mathrm{R}$ & Y & $\mathrm{R}$ & V & $\mathbf{R}$ & $S$ & A & $\mathrm{P}$ & $\mathrm{L}$ & G & \multicolumn{2}{|c|}{ intron } \\
\hline Platypus & D & $\mathrm{F}$ & I & $\mathrm{T}$ & $\mathrm{A}$ & $\mathrm{P}$ & $Y$ & $\mathrm{P}$ & Y & $Q$ & $I$ & $\mathrm{D}$ & D & V & K & Y & $\mathrm{R}$ & V & $\mathbf{R}$ & $S$ & $\mathrm{P}$ & $\mathrm{P}$ & $\mathrm{T}$ & G & \multicolumn{2}{|c|}{ intron } \\
\hline Chicken & & & & & & & & & & & & & & & & & & & & & & & & & & \\
\hline Lizard & D & $\mathrm{F}$ & I & S & A & S & Y & $\mathrm{P}$ & $\mathrm{F}$ & $Q$ & $\mathrm{~V}$ & V & $\mathrm{D}$ & $\mathrm{V}$ & $\mathrm{K}$ & Y & $\mathrm{R}$ & $\mathrm{V}$ & $\mathbf{R}$ & S & A & $\mathrm{P}$ & $\mathrm{T}$ & G & intro & \\
\hline Frog & D & $\mathrm{F}$ & I & S & A & S & Y & $\mathrm{P}$ & $\mathrm{F}$ & Q & V & V & D & V & K & Y & $\mathrm{R}$ & V & $\mathbf{K}$ & S & A & P & $\mathrm{T}$ & G & intro & \\
\hline Zebrafish & $=$ & $=$ & $=$ & $=$ & $=$ & $=$ & $=$ & $=$ & $=$ & $=$ & $=$ & $=$ & $=$ & $=$ & $=$ & $=$ & $=$ & $=$ & $=$ & $=$ & $=$ & $=$ & $=$ & $=$ & $=$ & \\
\hline CNGB1: p.A & & JII & & & & & & & & & & & & & & & & & & & & & & & & \\
\hline Human & intr & & $\mathrm{K}$ & K & $\mathrm{C}$ & V & Y & D & $\mathbf{N}$ & $\mathrm{P}$ & $\mathrm{L}$ & $\mathrm{Y}$ & V & V & S & $\mathrm{R}$ & L & $\mathrm{R}$ & K & L & $\mathrm{M}$ & $\mathrm{D}$ & $\mathrm{F}$ & I & $\mathrm{M}$ & $Q$ \\
\hline Chimp & intr & & K & K & $\mathrm{C}$ & $\mathrm{V}$ & Y & $\mathrm{D}$ & $\mathbf{N}$ & $\mathrm{P}$ & $\mathrm{L}$ & Y & V & V & S & $\mathrm{R}$ & L & $\mathrm{R}$ & K & L & $\mathrm{M}$ & $\mathrm{D}$ & $\mathrm{F}$ & I & M & $Q$ \\
\hline Rhesus & intr & & K & K & $\mathrm{C}$ & V & Y & $\mathrm{D}$ & $\mathbf{N}$ & $\mathrm{P}$ & $\mathrm{L}$ & Y & V & V & S & $\mathrm{R}$ & L & $\mathrm{R}$ & $\mathrm{K}$ & L & $\mathrm{M}$ & $\mathrm{D}$ & $\mathrm{F}$ & I & M & $Q$ \\
\hline Mouse & intr & con & K & K & $\mathrm{C}$ & V & Y & $\mathrm{D}$ & $\mathbf{N}$ & $\mathrm{P}$ & $\mathrm{L}$ & Y & V & V & S & $\mathrm{R}$ & $\mathrm{L}$ & $\mathrm{R}$ & K & L & M & $\mathrm{D}$ & $\mathrm{F}$ & I & $\mathrm{M}$ & $Q$ \\
\hline Rabbit & intr & & K & K & $\mathrm{C}$ & V & Y & $\mathrm{D}$ & $\mathbf{N}$ & $\mathrm{P}$ & L & Y & $\mathrm{V}$ & V & S & $\mathrm{R}$ & L & $\mathrm{R}$ & K & L & M & $\mathrm{D}$ & $\mathrm{F}$ & I & M & Q \\
\hline Pig & intr & & $\mathrm{K}$ & K & $\mathrm{C}$ & $\mathrm{V}$ & Y & $\mathrm{D}$ & $\mathbf{N}$ & $\mathrm{P}$ & $\mathrm{L}$ & Y & V & $\mathrm{V}$ & S & $\mathrm{R}$ & L & $\mathrm{R}$ & K & L & M & $\mathrm{D}$ & $\mathrm{F}$ & I & M & $Q$ \\
\hline Elephant & intr & & K & K & C & V & Y & $\mathrm{D}$ & $\mathbf{N}$ & $\mathrm{P}$ & L & Y & V & V & S & $\mathrm{R}$ & $\mathrm{L}$ & $\mathrm{R}$ & K & $\mathrm{L}$ & $\mathrm{M}$ & $\mathrm{D}$ & $\mathrm{F}$ & I & $\mathrm{M}$ & $Q$ \\
\hline Platypus & intr & & K & K & $\mathrm{C}$ & V & Y & D & $\mathbf{N}$ & $\mathrm{P}$ & L & Y & $\mathrm{V}$ & V & S & $\mathrm{R}$ & L & $\mathrm{R}$ & K & $\mathrm{L}$ & M & D & $\mathrm{F}$ & I & M & $Q$ \\
\hline Chicken & intr & & K & K & $\mathrm{C}$ & V & F & D & $\mathbf{N}$ & $\mathrm{P}$ & $\mathrm{L}$ & Y & V & V & S & $\mathrm{R}$ & $\mathrm{L}$ & $\mathrm{R}$ & K & $\mathrm{L}$ & M & D & $\mathrm{F}$ & I & M & $Q$ \\
\hline Lizard & intr & & K & K & $\mathrm{C}$ & $\mathrm{V}$ & F & $\mathrm{D}$ & G & $\mathrm{P}$ & $\mathrm{L}$ & Y & $\mathrm{V}$ & I & S & K & L & $\mathrm{R}$ & L & L & $\mathrm{M}$ & $\mathrm{D}$ & $\mathrm{C}$ & I & $\mathrm{M}$ & Q \\
\hline Frog & intr & & K & K & $\mathrm{C}$ & V & Y & $\mathrm{D}$ & G & $\mathrm{P}$ & L & Y & V & V & S & $\mathrm{R}$ & L & $\mathrm{R}$ & K & L & $\mathrm{M}$ & $\mathrm{D}$ & Y & I & $\mathrm{M}$ & $Q$ \\
\hline Zebrafish & intr & & $\mathrm{K}$ & $\mathrm{E}$ & $\mathrm{C}$ & $\mathrm{V}$ & $\mathrm{F}$ & D & G & $\mathrm{P}$ & L & Y & V & V & S & K & $\mathrm{L}$ & $\mathrm{R}$ & K & $\mathrm{L}$ & M & D & $\mathrm{F}$ & I & M & Q \\
\hline WDR19: P.I & & 51 & & & & & & & & & & & & & & & & & & & & & & & & \\
\hline Human & & V & A & Y & $\mathrm{E}$ & $\mathrm{N}$ & A & K & $Q$ & W & $Q$ & S & V & I & $\mathrm{R}$ & I & Y & $\mathrm{L}$ & D & $\mathrm{H}$ & $\mathrm{L}$ & $\mathrm{N}$ & $\mathrm{N}$ & $\mathrm{P}$ & $\mathrm{E}$ & K \\
\hline Chimp & & V & A & Y & $\mathrm{E}$ & $\mathrm{N}$ & A & K & $Q$ & W & $Q$ & S & V & I & $\mathrm{R}$ & I & Y & L & $\mathrm{D}$ & $\mathrm{H}$ & L & $\mathrm{N}$ & $\mathrm{N}$ & P & $\mathrm{E}$ & K \\
\hline Rhesus & & V & A & Y & $\mathrm{E}$ & $\mathrm{N}$ & A & K & Q & W & $Q$ & S & V & I & $\mathrm{R}$ & I & Y & L & $\mathrm{D}$ & $\mathrm{H}$ & L & $\mathrm{N}$ & $\mathrm{N}$ & $\mathrm{P}$ & $\mathrm{E}$ & K \\
\hline Mouse & & V & A & Y & $\mathrm{E}$ & $\mathrm{N}$ & A & K & $Q$ & W & $\mathrm{N}$ & S & V & I & $\mathrm{R}$ & I & Y & L & D & $\mathrm{H}$ & $\mathrm{L}$ & $\mathrm{N}$ & $\mathrm{N}$ & $\mathrm{P}$ & $\mathrm{E}$ & K \\
\hline Rabbit & & V & A & Y & $\mathrm{E}$ & $\mathrm{N}$ & A & K & $Q$ & W & $\mathrm{D}$ & S & V & I & $\mathrm{R}$ & $I$ & Y & $\mathrm{L}$ & D & $\mathrm{H}$ & $\mathrm{L}$ & $\mathrm{N}$ & $\mathrm{N}$ & $\mathrm{P}$ & $\mathrm{E}$ & K \\
\hline Pig & & V & A & Y & $\mathrm{E}$ & $\mathrm{N}$ & A & K & Q & W & $\mathrm{N}$ & S & V & I & $\mathrm{R}$ & I & $Y$ & $\mathrm{~L}$ & D & $\mathrm{H}$ & $\mathrm{L}$ & $\mathrm{N}$ & $\mathrm{N}$ & $\mathrm{P}$ & $\mathrm{E}$ & K \\
\hline Elephant & & A & $\mathrm{A}$ & Y & $\mathrm{E}$ & $\mathrm{N}$ & A & K & Q & W & $\mathrm{N}$ & S & V & I & $\mathrm{R}$ & I & Y & $\mathrm{L}$ & $\mathrm{D}$ & $\mathrm{H}$ & $\mathrm{L}$ & $\mathrm{N}$ & $\mathrm{N}$ & $\mathrm{P}$ & $\mathrm{E}$ & K \\
\hline Platypus & & V & A & Y & $\mathrm{E}$ & $\mathrm{N}$ & A & K & Q & W & $\mathrm{D}$ & S & V & I & $\mathrm{R}$ & $I$ & $Y$ & $\mathrm{~L}$ & D & $\mathrm{H}$ & $\mathrm{L}$ & S & $\mathrm{N}$ & $\mathrm{P}$ & $\mathrm{E}$ & K \\
\hline Chicken & & V & A & Y & $\mathrm{E}$ & $\mathrm{N}$ & A & K & Q & W & D & S & $\mathrm{V}$ & I & $\mathrm{R}$ & L & $\mathrm{C}$ & $\mathrm{L}$ & D & $\mathrm{H}$ & $\mathrm{L}$ & $\mathrm{N}$ & $\mathrm{N}$ & P & $\mathrm{E}$ & $\mathrm{R}$ \\
\hline Lizard & & L & A & Y & $\mathrm{E}$ & $\mathrm{N}$ & A & K & Q & W & D & $\mathrm{N}$ & $\mathrm{V}$ & I & $\mathrm{R}$ & L & Y & L & $\mathrm{D}$ & $\mathrm{H}$ & L & $\mathrm{N}$ & $\mathrm{N}$ & P & $\mathrm{E}$ & K \\
\hline Frog & & $\mathrm{L}$ & A & Y & $\mathrm{E}$ & $\mathrm{N}$ & $\mathrm{A}$ & K & $\mathrm{D}$ & W & D & $\mathrm{N}$ & $\mathrm{V}$ & I & $\mathrm{R}$ & I & S & L & D & $\mathrm{H}$ & L & $\mathrm{N}$ & $\mathrm{N}$ & $\mathrm{P}$ & $\mathrm{E}$ & K \\
\hline Zebrafish & & M & A & Y & $\mathrm{E}$ & $\mathrm{S}$ & $\mathrm{A}$ & $\mathrm{R}$ & $\mathrm{D}$ & W & $\mathrm{D}$ & $\mathrm{N}$ & $\mathrm{V}$ & $I$ & $\mathrm{R}$ & I & L & $\mathrm{L}$ & $\mathrm{E}$ & $\mathrm{H}$ & $\mathrm{L}$ & $\mathrm{N}$ & $\mathrm{N}$ & $\mathrm{P}$ & $\mathrm{E}$ & $\mathrm{E}$ \\
\hline EYS: $p$. & & $A I$ & & & & & & & & & & & & & & & & & & & & & & & & \\
\hline Human & & $\mathrm{C}$ & L & $\mathrm{C}$ & $\mathrm{S}$ & $\mathrm{Y}$ & S & $\mathrm{F}$ & $\mathrm{S}$ & $Q$ & $\mathrm{D}$ & $\mathrm{P}$ & I & C & L & S & $Q$ & $\mathrm{H}$ & L & $\mathrm{C}$ & $\mathrm{L}$ & $\mathrm{N}$ & $\mathrm{N}$ & $\mathrm{L}$ & $\mathrm{C}$ & S \\
\hline Chimp & & $\mathrm{C}$ & L & $\mathrm{C}$ & S & Y & S & $\mathrm{F}$ & S & Q & $\mathrm{D}$ & P & I & C & L & S & $Q$ & $\mathrm{H}$ & L & C & L & $\mathrm{N}$ & $\mathrm{N}$ & L & $\mathrm{C}$ & S \\
\hline Rhesus & & $\mathrm{C}$ & L & $\mathrm{C}$ & S & Y & S & $\mathrm{F}$ & S & $Q$ & D & $\mathrm{P}$ & I & $\mathrm{C}$ & L & S & $Q$ & $\mathrm{H}$ & $\mathrm{L}$ & C & $\mathrm{L}$ & $\mathrm{N}$ & $\mathrm{N}$ & $\mathrm{L}$ & $\mathrm{C}$ & Y \\
\hline Mouse & & $=$ & $=$ & $=$ & $=$ & $=$ & $=$ & $=$ & $=$ & $=$ & $=$ & $=$ & $=$ & $=$ & $=$ & $=$ & $=$ & $=$ & $=$ & $=$ & $=$ & $=$ & $=$ & $=$ & $=$ & $=$ \\
\hline Rabbit & & $\mathrm{C}$ & $\mathrm{L}$ & $\mathrm{C}$ & S & Y & S & $\mathrm{F}$ & S & $\mathrm{R}$ & D & $\mathrm{P}$ & I & C & $\mathrm{L}$ & S & $Q$ & $\mathrm{H}$ & $\mathrm{P}$ & $\mathrm{C}$ & $\mathrm{P}$ & $\mathrm{N}$ & $\mathrm{N}$ & $\mathrm{L}$ & $Y$ & $\mathrm{H}$ \\
\hline Pig & & $\mathrm{C}$ & $\mathrm{L}$ & $\mathrm{C}$ & $\mathrm{N}$ & Y & S & $\mathrm{F}$ & A & $Q$ & $\mathrm{~N}$ & $\mathrm{P}$ & I & C & $\mathrm{L}$ & S & $Q$ & $\mathrm{H}$ & $\mathrm{L}$ & $\mathrm{C}$ & $\mathrm{L}$ & $\mathrm{N}$ & $\mathrm{N}$ & $\mathrm{L}$ & $\mathrm{C}$ & Y \\
\hline Elephant & & $\mathrm{C}$ & L & $\mathrm{C}$ & S & Y & S & $\mathrm{F}$ & S & $\mathrm{E}$ & D & $\mathrm{P}$ & V & C & $\mathrm{L}$ & S & $Q$ & $\mathrm{H}$ & L & C & L & $\mathrm{N}$ & $\mathrm{N}$ & L & C & $\mathrm{Y}$ \\
\hline Platypus & & $\mathrm{C}$ & A & $\mathrm{C}$ & S & Y & S & $\mathrm{F}$ & $\mathrm{T}$ & $\mathrm{N}$ & D & $\mathrm{P}$ & I & C & $\mathrm{L}$ & S & Q & $\mathrm{H}$ & $Q$ & $\mathrm{C}$ & K & $\mathrm{N}$ & $\mathrm{N}$ & L & C & $\mathrm{N}$ \\
\hline Chicken & & $\mathrm{C}$ & $\mathrm{V}$ & $\mathrm{C}$ & $\mathrm{T}$ & Y & S & $\mathrm{L}$ & $\mathrm{L}$ & $\mathrm{P}$ & $Q$ & $\mathrm{P}$ & I & C & $\mathrm{L}$ & A & $Q$ & S & $\mathrm{R}$ & $\mathrm{C}$ & $\mathrm{R}$ & $\mathrm{N}$ & $\mathrm{H}$ & $\mathrm{L}$ & C & $\mathrm{H}$ \\
\hline Lizard & & $\mathrm{C}$ & M & $\mathrm{C}$ & $\mathrm{T}$ & $Y$ & S & $\mathrm{F}$ & L & $\mathrm{P}$ & $\mathrm{N}$ & $\mathrm{P}$ & L & C & I & G & G & $\mathrm{H}$ & L & C & K & $\mathrm{N}$ & $\mathrm{H}$ & S & $\mathrm{C}$ & Y \\
\hline Frog & & & & & & & & & & & & & & & & & & & & & & & & & & \\
\hline Zebrafish & & $\mathrm{C}$ & $\mathrm{M}$ & $\mathrm{C}$ & S & $\mathrm{Y}$ & S & A & S & $\mathrm{T}$ & $\mathrm{N}$ & $\mathrm{H}$ & I & $\mathrm{C}$ & $\mathrm{V}$ & $\mathrm{S}$ & $\mathrm{N}$ & $\mathrm{H}$ & $\mathrm{Q}$ & $\mathrm{C}$ & $\mathrm{L}$ & $\mathrm{N}$ & $\mathrm{N}$ & $\mathrm{L}$ & $\mathrm{C}$ & $\mathrm{Q}$ \\
\hline & & & & & & & & & & & & & & & & & & & & & & & & & & \\
\hline & & & & & & & & & & & & & & & & & & & & & & & & & & \\
\hline $\begin{array}{l}\text { Double line } \\
\text { more bases is }\end{array}$ & & & are th & & & & & & & & & & & & & & & & & & & & & 1 & one or & \\
\hline
\end{tabular}


Supplementary Table 3: Pathogenicity assessment of the novel variants according to ACMG guidelines (Richards et al. 2015)

\begin{tabular}{|c|c|c|c|c|c|c|}
\hline \multirow{2}{*}{ Gene } & \multirow{2}{*}{ Variant } & \multicolumn{4}{|c|}{ Evidence for } & \multirow{2}{*}{ Classification } \\
\hline & & Very Strong & Strong & Moderate & Supporting & \\
\hline ASICS & c. $58 \mathrm{~A}>\mathrm{T}$ & - & - & PM2 & PP3 & VUS \\
\hline PCDH15 & c. $2885 G>T$ & - & - & - & PP1 & VUS \\
\hline REEP6 & c.598+1delG & PVS1 & - & PM2, PM4 & PP1, PP3, PP4 & Pathogenic \\
\hline WDR19 & c. $1983-2 A>T$ & PVS1 & - & PM2 & PP3, PP4 & Pathogenic \\
\hline WDR19 & c. $2782 \mathrm{~A}>\mathrm{T}$ & - & - & PM2 & PP3, PP4 & VUS \\
\hline
\end{tabular}

Abbreviations:

PVS1, Pathogenic Very Strong criterion 1: Null variant (nonsense, frameshift, canonical \pm 1 or 2 splice sites, initiation codon, single or multiexon deletion) in a gene where LOF is a known mechanism of disease.

PM2, Pathogenic Moderate criterion 2: Absent from controls (or at extremely low frequency if recessive) in Exome Sequencing Project, 1000 Genomes Project, or Exome Aggregation Consortium.

PM4, Pathogenic Moderate criterion 4: Protein length changes as a result of in-frame deletions/insertions in a nonrepeat region or stop-loss variants.

PP1, Pathogenic Supporting criterion 1: Cosegregation with disease in multiple affected family members in a gene definitively known to cause the disease.

PP3, Pathogenic Supporting criterion 3: Multiple lines of computational evidence support a deleterious effect on the gene or gene product (conservation, evolutionary, splicing impact, etc.).

PP4, Pathogenic Supporting criterion 4: Patient' s phenotype or family history is highly specific for a disease with a single genetic etiology

VUS, Variant of Unknown Significance. 




\section{REFERENCES}

Abdelkader, E., Enani, L., Schatz, P., and Safieh, L., 2018. Severe retinal degeneration at an early age in Usher syndrome type $1 \mathrm{~B}$ associated with homozygous splice site mutations in MYO7A gene. Saudi Journal of Ophthalmology, 32 (2), 119-125.

Abu-Safieh, L., Alrashed, M., Anazi, S., Alkuraya, H., Khan, A.O., Al-Owain, M., Al-Zahrani, J., Al-Abdi, L., Hashem, M., Al-Tarimi, S., Sebai, M.-A., Shamia, A., Ray-Zack, M.D., Nassan, M., Al-Hassnan, Z.N., Rahbeeni, Z., Waheeb, S., Alkharashi, A., Abboud, E., Al-Hazzaa, S.A.F., and Alkuraya, F.S., 2013. Autozygome-guided exome sequencing in retinal dystrophy patients reveals pathogenetic mutations and novel candidate disease genes. Genome Research, 23 (2), 236-247.

Adato, A., Lefèvre, G., Delprat, B., Michel, V., Michalski, N., Chardenoux, S., Weil, D., El-Amraoui, A., and Petit, C., 2005a. Usherin, the defective protein in Usher syndrome type IIA, is likely to be a component of interstereocilia ankle links in the inner ear sensory cells. Human Molecular Genetics, 14 (24), 3921-3932.

Adato, A., Michel, V., Kikkawa, Y., Reiners, J., Alagramam, K.N., Weil, D., Yonekawa, H., Wolfrum, U., El-Amraoui, A., and Petit, C., 2005b. Interactions in the network of Usher syndrome type 1 proteins. Human Molecular Genetics, 14 (3), 347-356.

Adato, A., Vreugde, S., Joensuu, T., Avidan, N., Hamalainen, R., Belenkiy, O., Olender, T., Bonne-Tamir, B., Ben-Asher, E., Espinos, C., Millán, J.M., Lehesjoki, A.-E., Flannery, J.G., Avraham, K.B., Pietrokovski, S., Sankila, E.-M., Beckmann, J.S., and Lancet, D., 2002. USH3A transcripts encode clarin-1, a four-transmembrane-domain protein with a possible role in sensory synapses. European journal of human genetics: EJHG, 10 (6), 339-350.

Adato, A., Weil, D., Kalinski, H., Pel-Or, Y., Ayadi, H., Petit, C., Korostishevsky, M., and Bonne-Tamir, B., 1997. Mutation profile of all 49 exons of the human myosin VIIA gene, and haplotype analysis, in Usher 1B families from diverse origins. American Journal of Human Genetics, 61 (4), 813-821.

Adzhubei, I.A., Schmidt, S., Peshkin, L., Ramensky, V.E., Gerasimova, A., Bork, P., Kondrashov, A.S., and Sunyaev, S.R., 2010. A method and server for predicting damaging missense mutations. Nature Methods, 7 (4), 248-249.

Ahmed, Z.M., Goodyear, R., Riazuddin, S., Lagziel, A., Legan, P.K., Behra, M., Burgess, S.M., Lilley, K.S., Wilcox, E.R., Riazuddin, S., Griffith, A.J., Frolenkov, G.l., Belyantseva, I.A., Richardson, G.P., and Friedman, T.B., 2006. The tip-link antigen, a protein associated with the transduction complex of sensory hair cells, is protocadherin-15. The Journal of Neuroscience: The Official Journal of the Society for Neuroscience, 26 (26), 7022-7034.
Ahmed, Z.M., Jaworek, T.J., Sarangdhar, G.N., Zheng, L., Gul, K., Khan, S.N., Friedman, T.B., Sisk, R.A., Bartles, J.R., Riazuddin, S., and Riazuddin, S., 2018. Inframe deletion of human ESPN is associated with deafness, vestibulopathy and vision impairment. Journal of Medical Genetics, 55 (7), 479-488.

Ahmed, Z.M., Riazuddin, S., Ahmad, J., Bernstein, S.L., Guo, Y., Sabar, M.F., Sieving, P., Riazuddin, S., Griffith, A.J., Friedman, T.B., Belyantseva, I.A., and Wilcox, E.R., 2003. $\mathrm{PCDH} 15$ is expressed in the neurosensory epithelium of the eye and ear and mutant alleles are responsible for both USH1F and DFNB23. Human Molecular Genetics, 12 (24), 3215-3223.

Ahmed, Z.M., Riazuddin, S., Aye, S., Ali, R.A., Venselaar, H., Anwar, S., Belyantseva, P.P., Qasim, M., Riazuddin, S., and Friedman, T.B., 2008. Gene structure and mutant alleles of PCDH15: nonsyndromic deafness DFNB23 and type 1 Usher syndrome. Human Genetics, 124 (3), 215-223.

Ahmed, Z.M., Riazuddin, S., Bernstein, S.L., Ahmed, Z., Khan, S., Griffith, A.J., Morell, R.J., Friedman, T.B., Riazuddin, S., and Wilcox, E.R., 2001. Mutations of the protocadherin gene PCDH15 cause Usher syndrome type 1F. American Journal of Human Genetics, 69 (1), 25-34.

Ahmed, Z.M., Smith, T.N., Riazuddin, S., Makishima, T., Ghosh, M., Bokhari, S., Menon, P.S.N., Deshmukh, D., Griffith, A.J., Riazuddin, S., Friedman, T.B., and Wilcox, E.R., 2002. Nonsyndromic recessive deafness DFNB18 and Usher syndrome type IC are allelic mutations of USHIC. Human Genetics, 110 (6), 527-531.

Aird, E.J., Lovendahl, K.N., St. Martin, A., Harris, R.S., and Gordon, W.R., 2018. Increasing Cas9-mediated homology-directed repair efficiency through covalent tethering of DNA repair template. Communications Biology, 1.

Alagramam, K.N., Gopal, S.R., Geng, R., Chen, D.H.-C., Nemet, I., Lee, R., Tian, G., Miyagi, M., Malagu, K.F., Lock, C.J., Esmieu, W.R.K., Owens, A.P., Lindsay, N.A., Ouwehand, K., Albertus, F., Fischer, D.F., Bürli, R.W., MacLeod, A.M., Harte, W.E., Palczewski, K., and Imanishi, Y., 2016. A small molecule mitigates hearing loss in a mouse model of Usher syndrome III. Nature chemical biology, 12 (6), 444-451.

Alagramam, K.N., Yuan, H., Kuehn, M.H., Murcia, C.L., Wayne, S., Srisailpathy, C.R.S., Lowry, R.B., Knaus, R., Van Laer, L., Bernier, F.P., Schwartz, S., Lee, C., Morton, C.C., Mullins, R.F., Ramesh, A., Van Camp, G., Hagemen, G.S., Woychik, R.P., and Smith, R.J.H., 2001. Mutations in the novel protocadherin PCDH15 cause Usher syndrome type 1F. Human Molecular Genetics, 10 (16), 1709-1718. 
Allen, F., Crepaldi, L., Alsinet, C., Strong, A.J., Kleshchevnikov, V., De Angeli, P., Páleníková, P., Khodak, A., Kiselev, V., Kosicki, M., Bassett, A.R., Harding, H., Galanty, Y., Muñoz-Martínez, F., Metzakopian, E., Jackson, S.P., and Parts, L., 2019. Predicting the mutations generated by repair of Cas9-induced doublestrand breaks. Nature Biotechnology, 37 (1), 64-72.

Aller, E., Jaijo, T., Beneyto, M., Nájera, C., Oltra, S., Ayuso, C., Baiget, M., Carballo, M., Antiñolo, G., Valverde, D., Moreno, F., Vilela, C., Collado, D., Pérez-Garrigues, H., Navea, A., and Millán, J.M., 2006. Identification of 14 novel mutations in the long isoform of USH2A in Spanish patients with Usher syndrome type II. Journal of Medical Genetics, 43 (11), e55.

Aller, E., Jaijo, T., García-García, G., Aparisi, M.J., Blesa, D., Díaz-Llopis, M., Ayuso, C., and Millán, J.M., 2010a. Identification of large rearrangements of the PCDH15 gene by combined MLPA and a CGH: large duplications are responsible for Usher syndrome. Investigative Ophthalmology \& Visual Science, 51 (11), 5480-5485.

Aller, E., Larrieu, L., Jaijo, T., Baux, D., Espinós, C., GonzálezCandelas, F., Nájera, C., Palau, F., Claustres, M., Roux, A.F., and Millán, J.M., 2010b. The USH2A c.2299delG mutation: dating its common origin in a Southern European population. European Journal of Human Genetics, 18 (7), 788-793.

Aller, E., Nájera, C., Millán, J.M., Oltra, J.S., Pérez-Garrigues, H., Vilela, C., Navea, A., and Beneyto, M., 2004. Genetic analysis of 2299delG and C759F mutations (USH2A) in patients with visual and/or auditory impairments. European journal of human genetics: EJHG, 12 (5), 407410.

Anderson, E.M., Haupt, A., Schiel, J.A., Chou, E., Machado, H.B., Strezoska, Ž., Lenger, S., McClelland, S., Birmingham, A., Vermeulen, A., and Smith, A. van B., 2015. Systematic analysis of CRISPR-Cas9 mismatch tolerance reveals low levels of off-target activity. Journal of Biotechnology, 211, 56-65.

Aparisi, M.J., Aller, E., Fuster-García, C., García-García, G., Rodrigo, R., Vázquez-Manrique, R.P., Blanco-Kelly, F., Ayuso, C., Roux, A.-F., Jaijo, T., and Millán, J.M., 2014. Targeted next generation sequencing for molecular diagnosis of Usher syndrome. Orphanet Journal of Rare Diseases, 9, 168.

Aparisi, M.J., García-García, G., Aller, E., Sequedo, M.D., Martínez-Fernández de la Cámara, C., Rodrigo, R., Armengot, M., Cortijo, J., Milara, J., Díaz-LLopis, M., Jaijo, T., and Millán, J.M., 2013. Study of USH1 Splicing Variants through Minigenes and Transcript Analysis from Nasal Epithelial Cells. PLOSONE, 8 (2).

Araya-Secchi, R., Neel, B.L., and Sotomayor, M., 2016. An elastic element in the protocadherin-15 tip link of the inner ear. Nature Communications, 7, 13458.
Arno, G., Agrawal, S.A., Eblimit, A., Bellingham, J., Xu, M., Wang, F., Chakarova, C., Parfitt, D.A., Lane, A., Burgoyne, T., Hull, S., Carss, K.J., Fiorentino, A., Hayes, M.J., Munro, P.M., Nicols, R., Pontikos, N., Holder, G.E., UKIRDC, Asomugha, C., Raymond, F.L., Moore, A.T., Plagnol, V., Michaelides, M., Hardcastle, A.J., Li, Y., Cukras, C., Webster, A.R., Cheetham, M.E., and Chen, R., 2016. Mutations in REEP6 Cause Autosomal-Recessive Retinitis Pigmentosa. American Journal of Human Genetics, 99 (6), 1305-1315.

Ashmore, J., 2018. Outer Hair Cells and Electromotility. Cold Spring Harbor Perspectives in Medicine.

Astuto, L.M., Bork, J.M., Weston, M.D., Askew, J.W., Fields, R.R., Orten, D.J., Ohliger, S.J., Riazuddin, S., Morell, R.J., Khan, S., Riazuddin, S., Kremer, H., van Hauwe, P., Moller, C.G., Cremers, C.W.R.J., Ayuso, C., Heckenlively, J.R., Rohrschneider, K., Spandau, U., Greenberg, J., Ramesar, R., Reardon, W., Bitoun, P., Millan, J., Legge, R., Friedman, T.B., and Kimberling, W.J., 2002. CDH23 mutation and phenotype heterogeneity: a profile of 107 diverse families with Usher syndrome and nonsyndromic deafness. American Journal of Human Genetics, 71 (2), 262-275.

Audo, I., Bujakowska, K., Mohand-Saïd, S., Tronche, S., Lancelot, M.-E., Antonio, A., Germain, A., Lonjou, C., Carpentier, W., Sahel, J.-A., Bhattacharya, S., and Zeitz, C., 2011. A novel DFNB31 mutation associated with Usher type 2 syndrome showing variable degrees of auditory loss in a consanguineous Portuguese family. Molecular Vision, 17, 1598-1606.

Audo, I., Sahel, J.-A., Mohand-Saïd, S., Lancelot, M.-E., Antonio, A., Moskova-Doumanova, V., Nandrot, E.F., Doumanov, J., Barragan, I., Antinolo, G., Bhattacharya, S.S., and Zeitz, C., 2010. EYS is a major gene for rod-cone dystrophies in France. Human Mutation, 31 (5), E14061435.

Bae, S., Park, J., and Kim, J.-S., 2014. Cas-OFFinder: a fast and versatile algorithm that searches for potential offtarget sites of Cas9 RNA-guided endonucleases. Bioinformatics, 30 (10), 1473-1475.

Bahloul, A., Michel, V., Hardelin, J.-P., Nouaille, S., Hoos, S., Houdusse, A., England, P., and Petit, C., 2010. Cadherin23, myosin Vlla and harmonin, encoded by Usher syndrome type I genes, form a ternary complex and interact with membrane phospholipids. Human Molecular Genetics, 19 (18), 3557-3565.

Barber, A.C., Hippert, C., Duran, Y., West, E.L., Bainbridge, J.W.B., Warre-Cornish, K., Luhmann, U.F.O., Lakowski, J., Sowden, J.C., Ali, R.R., and Pearson, R.A., 2013. Repair of the degenerate retina by photoreceptor transplantation. Proceedings of the National Academy of Sciences of the United States of America, 110 (1), 354-359. 
Barnea-Cramer, A.O., Wang, W., Lu, S.-J., Singh, M.S., Luo, C., Huo, H., McClements, M.E., Barnard, A.R., MacLaren, R.E., and Lanza, R., 2016. Function of human pluripotent stem cell-derived photoreceptor progenitors in blind mice. Scientific Reports, 6, 29784.

Barnes, D.E., 2001. Non-homologous end joining as a mechanism of DNA repair. Current biology: $C B, 11$ (12), R455-457.

Bartsch, T.F., Hengel, F.E., Oswald, A., Dionne, G., Chipendo, I.V., Mangat, S.S., El Shatanofy, M., Shapiro, L., Müller, U., and Hudspeth, A.J., 2019. Elasticity of individual protocadherin 15 molecules implicates tip links as the gating springs for hearing. Proceedings of the National Academy of Sciences of the United States of America.

Bashir, R., Fatima, A., and Naz, S., 2010. A frameshift mutation in SANS results in atypical Usher syndrome. Clinical Genetics, 78 (6), 601-603.

Bauß, K., Knapp, B., Jores, P., Roepman, R., Kremer, H., Wijk, E.V., Märker, T., and Wolfrum, U., 2014. Phosphorylation of the Usher syndrome $1 \mathrm{G}$ protein SANS controls Magi2-mediated endocytosis. Human Molecular Genetics, 23 (15), 3923-3942.

Baux, D., Blanchet, C., Hamel, C., Meunier, I., Larrieu, L., Faugère, V., Vaché, C., Castorina, P., Puech, B., Bonneau, D., Malcolm, S., Claustres, M., and Roux, A.-F., 2014. Enrichment of LOVD-USHbases with 152 USH2A genotypes defines an extensive mutational spectrum and highlights missense hotspots. Human Mutation, 35 (10), 1179-1186.

Baux, D., Faugère, V., Larrieu, L., Le Guédard-Méreuze, S., Hamroun, D., Béroud, C., Malcolm, S., Claustres, M., and Roux, A.-F., 2008. UMD-USHbases: a comprehensive set of databases to record and analyse pathogenic mutations and unclassified variants in seven Usher syndrome causing genes. Human Mutation, 29 (8), E7687.

Baux, D., Larrieu, L., Blanchet, C., Hamel, C., Ben Salah, S., Vielle, A., Gilbert-Dussardier, B., Holder, M., Calvas, P., Philip, N., Edery, P., Bonneau, D., Claustres, M., Malcolm, S., and Roux, A.-F., 2007. Molecular and in silico analyses of the full-length isoform of usherin identify new pathogenic alleles in Usher type II patients. Human Mutation, 28 (8), 781-789.

Baux, D., Vaché, C., Blanchet, C., Willems, M., Baudoin, C., Moclyn, M., Faugère, V., Touraine, R., Isidor, B., DupinDeguine, D., Nizon, M., Vincent, M., Mercier, S., Calais, C., García-García, G., Azher, Z., Lambert, L., PerdomoTrujillo, Y., Giuliano, F., Claustres, M., Koenig, M., Mondain, M., and Roux, A.F., 2017. Combined genetic approaches yield a $48 \%$ diagnostic rate in a large cohort of French hearing-impaired patients. Scientific Reports, 7.
Becirovic, E., Ebermann, I., Nagy, D., Zrenner, E., Seeliger, M.W., and Bolz, H.J., 2008. Usher syndrome type 1 due to missense mutations on both $\mathrm{CDH} 23$ alleles: investigation of mRNA splicing. Human Mutation, 29 (3), 452.

Becker, S., Wang, H., Stoddard, G.J., and Hartnett, M.E., 2017. Effect of subretinal injection on retinal structure and function in a rat oxygen-induced retinopathy model. Molecular Vision, 23, 832-843.

Benhar, I., London, A., and Schwartz, M., 2012. The privileged immunity of immune privileged organs: the case of the eye. Frontiers in Immunology, 3.

Ben-Yosef, T., Ness, S.L., Madeo, A.C., Bar-Lev, A., Wolfman, J.H., Ahmed, Z.M., Desnick, R.J., Willner, J.P., Avraham, K.B., Ostrer, H., Oddoux, C., Griffith, A.J., and Friedman, T.B., 2003. A mutation of PCDH15 among Ashkenazi Jews with the type 1 Usher syndrome. The New England Journal of Medicine, 348 (17), 1664-1670.

Berger, W., Kloeckener-Gruissem, B., and Neidhardt, J., 2010. The molecular basis of human retinal and vitreoretinal diseases. Progress in Retinal and Eye Research, 29 (5), 335-375.

Berkovic, S.F., Staropoli, J.F., Carpenter, S., Oliver, K.L., Kmoch, S., Anderson, G.W., Damiano, J.A., Hildebrand, M.S., Sims, K.B., Cotman, S.L., Bahlo, M., Smith, K.R., Cadieux-Dion, M., Cossette, P., Jedličková, I., Přistoupilová, A., and Mole, S.E., 2016. Diagnosis and misdiagnosis of adult neuronal ceroid lipofuscinosis (Kufs disease). Neurology, 87 (6), 579-584.

Berlin, S. and Isacoff, E.Y., 2017. Synapses in the spotlight with synthetic optogenetics. EMBO Reports, 18 (5), 677692.

Bernal, S., Medà, C., Solans, T., Ayuso, C., Garcia-Sandoval, B., Valverde, D., Del Rio, E., and Baiget, M., 2005. Clinical and genetic studies in Spanish patients with Usher syndrome type II: description of new mutations and evidence for a lack of genotype--phenotype correlation. Clinical Genetics, 68 (3), 204-214.

Besnard, T., García-García, G., Baux, D., Vaché, C., Faugère, V., Larrieu, L., Léonard, S., Millan, J.M., Malcolm, S., Claustres, M., and Roux, A.-F., 2014. Experience of targeted Usher exome sequencing as a clinical test. Molecular Genetics \& Genomic Medicine, 2 (1), 30-43.

Besnard, T., Vaché, C., Baux, D., Larrieu, L., Abadie, C., Blanchet, C., Odent, S., Blanchet, P., Calvas, P., Hamel, C., Dollfus, H., Lina-Granade, G., Lespinasse, J., David, A., Isidor, B., Morin, G., Malcolm, S., Tuffery-Giraud, S., Claustres, M., and Roux, A.-F., 2012. Non-USH2A mutations in USH2 patients. Human Mutation, 33 (3), 504-510. 
Bharadwaj, A.K., Kasztejna, J.P., Huq, S., Berson, E.L., and Dryja, T.P., 2000. Evaluation of the myosin VIIA gene and visual function in patients with Usher syndrome type I. Experimental Eye Research, 71 (2), 173-181.

Bhattacharya, G., Miller, C., Kimberling, W.J., Jablonski, M.M., and Cosgrove, D., 2002. Localization and expression of usherin: a novel basement membrane protein defective in people with Usher' s syndrome type Ila. Hearing Research, 163 (1-2), 1-11.

Birch, D.G., 1999. Retinal degeneration in retinitis pigmentosa and neuronal ceroid lipofuscinosis: An overview. Molecular Genetics and Metabolism, 66 (4), 356-366.

Bitner-Glindzicz, M., Lindley, K.J., Rutland, P., Blaydon, D., Smith, V.V., Milla, P.J., Hussain, K., Furth-Lavi, J., Cosgrove, K.E., Shepherd, R.M., Barnes, P.D., O' Brien, R.E., Farndon, P.A., Sowden, J., Liu, X.Z., Scanlan, M.J., Malcolm, S., Dunne, M.J., Aynsley-Green, A., and Glaser, B., 2000. A recessive contiguous gene deletion causing infantile hyperinsulinism, enteropathy and deafness identifies the Usher type $1 C$ gene. Nature Genetics, 26 (1), 56-60.

Blanco-Sánchez, B., Clément, A., Fierro, J., Washbourne, P., and Westerfield, M., 2014. Complexes of Usher proteins preassemble at the endoplasmic reticulum and are required for trafficking and ER homeostasis. Disease Models \& Mechanisms, 7 (5), 547-559.

Bloch, E., Luo, Y., and da Cruz, L., 2019. Advances in retinal prosthesis systems. Therapeutic Advances in Ophthalmology, 11.

Boëda, B., El-Amraoui, A., Bahloul, A., Goodyear, R., Daviet, L., Blanchard, S., Perfettini, I., Fath, K.R., Shorte, S., Reiners, J., Houdusse, A., Legrain, P., Wolfrum, U., Richardson, G., and Petit, C., 2002. Myosin VIla, harmonin and cadherin 23 , three Usher I gene products that cooperate to shape the sensory hair cell bundle. The EMBO journal, 21 (24), 6689-6699.

Boiko, N., Kucher, V., Wang, B., and Stockand, J.D., 2014. Restrictive expression of acid-sensing ion channel 5 (asic5) in unipolar brush cells of the vestibulocerebellum. PloS One, 9 (3), e91326.

Bolz, H., von Brederlow, B., Ramírez, A., Bryda, E.C., Kutsche, K., Nothwang, H.G., Seeliger, M., del C-Salcedó Cabrera, M., Vila, M.C., Molina, O.P., Gal, A., and Kubisch, C., 2001. Mutation of $\mathrm{CDH} 23$, encoding a new member of the cadherin gene family, causes Usher syndrome type 1D. Nature Genetics, 27 (1), 108-112.

Bonneau, D., Raymond, F., Kremer, C., Klossek, J.M., Kaplan, J., and Patte, F., 1993. Usher syndrome type I associated with bronchiectasis and immotile nasal cilia in two brothers. Journal of Medical Genetics, 30 (3), 253254.
Bonnet, C., Grati, M., Marlin, S., Levilliers, J., Hardelin, J.-P., Parodi, M., Niasme-Grare, M., Zelenika, D., Délépine, M., Feldmann, D., Jonard, L., El-Amraoui, A., Weil, D., Delobel, B., Vincent, C., Dollfus, H., Eliot, M.-M., David, A., Calais, C., Vigneron, J., Montaut-Verient, B., Bonneau, D., Dubin, J., Thauvin, C., Duvillard, A., Francannet, C., Mom, T., Lacombe, D., Duriez, F., Drouin-Garraud, V., ThuillierObstoy, M.-F., Sigaudy, S., Frances, A.-M., Collignon, P., Challe, G., Couderc, R., Lathrop, M., Sahel, J.-A., Weissenbach, J., Petit, C., and Denoyelle, F., 2011. Complete exon sequencing of all known Usher syndrome genes greatly improves molecular diagnosis. Orphanet Journal of Rare Diseases, 6, 21.

Bonnet, C., Riahi, Z., Chantot-Bastaraud, S., Smagghe, L., Letexier, M., Marcaillou, C., Lefèvre, G.M., Hardelin, J.-P., El-Amraoui, A., Singh-Estivalet, A., Mohand-Saïd, S., Kohl, S., Kurtenbach, A., Sliesoraityte, I., Zobor, D., Gherbi, S., Testa, F., Simonelli, F., Banfi, S., Fakin, A., Glavač, D., Jarc-Vidmar, M., Zupan, A., Battelino, S., Martorell Sampol, L., Claveria, M.A., Catala Mora, J., Dad, S., Møller, L.B., Rodriguez Jorge, J., Hawlina, M., Auricchio, A., Sahel, J.-A., Marlin, S., Zrenner, E., Audo, I., and Petit, C., 2016. An innovative strategy for the molecular diagnosis of Usher syndrome identifies causal biallelic mutations in 93\% of European patients. European journal of human genetics: EJHG, 24 (12), 1730-1738.

Booth, K.T., Kahrizi, K., Babanejad, M., Daghagh, H., Bademci, G., Arzhangi, S., Zareabdollahi, D., Duman, D., El-Amraoui, A., Tekin, M., Najmabadi, H., Azaiez, H., and Smith, R.J., 2018. Variants in CIB2 cause DFNB48 and not USH1J. Clinical Genetics, 93 (4), 812-821.

Bork, J.M., Peters, L.M., Riazuddin, S., Bernstein, S.L., Ahmed, Z.M., Ness, S.L., Polomeno, R., Ramesh, A., Schloss, M., Srisailpathy, C.R., Wayne, S., Bellman, S., Desmukh, D., Ahmed, Z., Khan, S.N., Kaloustian, V.M., Li, X.C., Lalwani, A., Riazuddin, S., Bitner-Glindzicz, M., Nance, W.E., Liu, X.Z., Wistow, G., Smith, R.J., Griffith, A.J., Wilcox, E.R., Friedman, T.B., and Morell, R.J., 2001. Usher syndrome $1 D$ and nonsyndromic autosomal recessive deafness DFNB12 are caused by allelic mutations of the novel cadherin-like gene $\mathrm{CDH} 23$. American Journal of Human Genetics, 68 (1), 26-37.

van den Bosch, M., Lohman, P.H.M., and Pastink, A., 2002. DNA double-strand break repair by homologous recombination. Biological Chemistry, 383 (6), 873-892.

Boughman, J.A., Vernon, M., and Shaver, K.A., 1983. Usher syndrome: definition and estimate of prevalence from two high-risk populations. Journal of Chronic Diseases, 36 (8), 595-603.

Bragg, L.M., Stone, G., Butler, M.K., Hugenholtz, P., and Tyson, G.W., 2013. Shining a Light on Dark Sequencing: Characterising Errors in lon Torrent PGM Data. PLOS Computational Biology, 9 (4). 
von Brederlow, B., Bolz, H., Janecke, A., La O Cabrera, A., Rudolph, G., Lorenz, B., Schwinger, E., and Gal, A., 2002. Identification and in vitro expression of novel $\mathrm{CDH} 23$ mutations of patients with Usher syndrome type 1D. Human Mutation, 19 (3), 268-273.

Bredrup, C., Saunier, S., Oud, M.M., Fiskerstrand, T., Hoischen, A., Brackman, D., Leh, S.M., Midtbø, M., Filhol, E., Bole-Feysot, C., Nitschké, P., Gilissen, C., Haugen, O.H., Sanders, J.-S.F., Stolte-Dijkstra, I., Mans, D.A., Steenbergen, E.J., Hamel, B.C.J., Matignon, M., Pfundt, R., Jeanpierre, C., Boman, H., Rødahl, E., Veltman, J.A., Knappskog, P.M., Knoers, N.V.A.M., Roepman, R., and Arts, H.H., 2011. Ciliopathies with Skeletal Anomalies and Renal Insufficiency due to Mutations in the IFT-A Gene WDR19. American Journal of Human Genetics, 89 (5), 634-643.

Brigande, J.V., Gubbels, S.P., Woessner, D.W., Jungwirth, J.J., and Bresee, C.S., 2009. Electroporation-Mediated Gene Transfer to the Developing Mouse Inner Ear. Methods in molecular biology (Clifton, N.J.), 493, 125139.

Brunak, S., Engelbrecht, J., and Knudsen, S., 1991. Prediction of human mRNA donor and acceptor sites from the DNA sequence. Journal of Molecular Biology, 220 (1), 49-65.

Bujakowska, K.M., Consugar, M., Place, E., Harper, S., Lena, J., Taub, D.G., White, J., Navarro-Gomez, D., Weigel DiFranco, C., Farkas, M.H., Gai, X., Berson, E.L., and Pierce, E.A., 2014. Targeted exon sequencing in Usher syndrome type I. Investigative Ophthalmology \& Visual Science, 55 (12), 8488-8496.

Burgess, D.J., 2013. Technology: a CRISPR genome-editing tool. Nature Reviews. Genetics, 14 (2), 80.

Caberlotto, E., Michel, V., Foucher, I., Bahloul, A., Goodyear, R.J., Pepermans, E., Michalski, N., Perfettini, I., Alegria-Prévot, O., Chardenoux, S., Do Cruzeiro, M., Hardelin, J.-P., Richardson, G.P., Avan, P., Weil, D., and Petit, C., 2011. Usher type $1 G$ protein sans is a critical component of the tip-link complex, a structure controlling actin polymerization in stereocilia. Proceedings of the National Academy of Sciences of the United States of America, 108 (14), 5825-5830.

Cai, Y., Cheng, T., Yao, Y., Li, X., Ma, Y., Li, L., Zhao, H., Bao, J., Zhang, M., Qiu, Z., and Xue, T., 2019. In vivo genome editing rescues photoreceptor degeneration via a Cas9/RecA-mediated homology-directed repair pathway. Science Advances, 5 (4).

Calado, S.M., Garcia-Delgado, A.B., De la Cerda, B., PonteZuñiga, B., Bhattacharya, S.S., and Díaz-Corrales, F.J., 2018. Generation of a human iPS cell line from a patient with retinitis pigmentosa due to EYS mutation. Stem Cell Research, 33, 251-254.
Canny, M.D., Moatti, N., Wan, L.C.K., Fradet-Turcotte, A., Krasner, D., Mateos-Gomez, P.A., Zimmermann, M., Orthwein, A., Juang, Y.-C., Zhang, W., Noordermeer, S.M., Seclen, E., Wilson, M.D., Vorobyov, A., Munro, M., Ernst, A., Ng, T.F., Cho, T., Cannon, P.M., Sidhu, S.S., Sicheri, F., and Durocher, D., 2018. Inhibition of 53BP1 favors homology-dependent DNA repair and increases CRISPR-Cas9 genome-editing efficiency. Nature Biotechnology, 36 (1), 95-102.

Carss, K.J., Arno, G., Erwood, M., Stephens, J., Sanchis-Juan, A., Hull, S., Megy, K., Grozeva, D., Dewhurst, E., Malka, S., Plagnol, V., Penkett, C., Stirrups, K., Rizzo, R., Wright, G., Josifova, D., Bitner-Glindzicz, M., Scott, R.H., Clement, E., Allen, L., Armstrong, R., Brady, A.F., Carmichael, J., Chitre, M., Henderson, R.H.H., Hurst, J., MacLaren, R.E., Murphy, E., Paterson, J., Rosser, E., Thompson, D.A., Wakeling, E., Ouwehand, W.H., Michaelides, M., Moore, A.T., Webster, A.R., and Raymond, F.L., 2017. Comprehensive Rare Variant Analysis via Whole-Genome Sequencing to Determine the Molecular Pathology of Inherited Retinal Disease. American Journal of Human Genetics, 100 (1), 75-90.

Cashman, S.M., McCullough, L., and Kumar-Singh, R., 2007. Improved Retinal Transduction In Vivo and Photoreceptor-specific Transgene Expression Using Adenovirus Vectors With Modified Penton Base. Molecular Therapy, 15 (9), 1640-1646.

de Castro-Miró, M., Tonda, R., Escudero-Ferruz, P., Andrés, R., Mayor-Lorenzo, A., Castro, J., Ciccioli, M., Hidalgo, D.A., Rodríguez-Ezcurra, J.J., Farrando, J., PérezSantonja, J.J., Cormand, B., Marfany, G., and GonzàlezDuarte, R., 2016. Novel Candidate Genes and a Wide Spectrum of Structural and Point Mutations Responsible for Inherited Retinal Dystrophies Revealed by Exome Sequencing. PLOS ONE, 11 (12).

Cech, D.J. and Martin, S. "Tink" , 2012. Chapter 10 Sensory System Changes. Im. D.J. Cech and S. "Tink" Martin, eds. Functional Movement Development Across the Life Span (Third Edition). Saint Louis: W.B. Saunders, 213-238.

Chakrabarti, A.M., Henser-Brownhill, T., Monserrat, J., Poetsch, A.R., Luscombe, N.M., and Scaffidi, P., 2019. Target-Specific Precision of CRISPR-Mediated Genome Editing. Molecular Cell, 73 (4), 699-713.e6.

Charlesworth, C.T., Deshpande, P.S., Dever, D.P., Camarena, J., Lemgart, V.T., Cromer, M.K., Vakulskas, C.A., Collingwood, M.A., Zhang, L., Bode, N.M., Behlke, M.A., Dejene, B., Cieniewicz, B., Romano, R., Lesch, B.J., Gomez-Ospina, N., Mantri, S., Pavel-Dinu, M., Weinberg, K.I., and Porteus, M.H., 2019. Identification of preexisting adaptive immunity to Cas 9 proteins in humans. Nature Medicine, 25 (2), 249-254. 
Chemi, G., Brindisi, M., Brogi, S., Relitti, N., Butini, S., Gemma, S., and Campiani, G., 2019. A light in the dark: state of the art and perspectives in optogenetics and optopharmacology for restoring vision. Future Medicinal Chemistry, 11 (5), 463-487.

Chen, F., Pruett-Miller, S.M., Huang, Y., Gjoka, M., Duda, K., Taunton, J., Collingwood, T.N., Frodin, M., and Davis, G.D., 2011. High-frequency genome editing using ssDNA oligonucleotides with zinc-finger nucleases. Nature Methods, 8 (9), 753-755.

Chen, J.S., Dagdas, Y.S., Kleinstiver, B.P., Welch, M.M., Sousa, A.A., Harrington, L.B., Sternberg, S.H., Joung, J.K., Yildiz, A., and Doudna, J.A., 2017. Enhanced proofreading governs CRISPR-Cas9 targeting accuracy. Nature, 550 (7676), 407-410.

Chen, X., Rinsma, M., Janssen, J.M., Liu, J., Maggio, I., and Gonçalves, M.A.F.V., 2016. Probing the impact of chromatin conformation on genome editing tools. Nucleic Acids Research, gkw524.

Chen, X., Sheng, X., Liu, X., Li, H., Liu, Y., Rong, W., Ha, S., Liu, W., Kang, X., Zhao, K., and Zhao, C., 2014. Targeted next-generation sequencing reveals novel USH2A mutations associated with diverse disease phenotypes: implications for clinical and molecular diagnosis. P/oS One, 9 (8), e105439.

Chen, Z.Y., Hasson, T., Kelley, P.M., Schwender, B.J., Schwartz, M.F., Ramakrishnan, M., Kimberling, W.J., Mooseker, M.S., and Corey, D.P., 1996. Molecular cloning and domain structure of human myosin-VIla, the gene product defective in Usher syndrome $1 \mathrm{~B}$. Genomics, 36 (3), 440-448.

Cheng, L., Yu, H., Jiang, Y., He, J., Pu, S., Li, X., and Zhang, L., 2017. Identification of a novel MYO7A mutation in Usher syndrome type 1. Oncotarget, 9 (2), 2295-2303.

Cheng, Y.-R., Jiang, B.-Y., and Chen, C.-C., 2018. Acidsensing ion channels: dual function proteins for chemosensing and mechano-sensing. Journal of Biomedical Science, 25.

Choi, Y. and Chan, A.P., 2015. PROVEAN web server: a tool to predict the functional effect of amino acid substitutions and indels. Bioinformatics, 31 (16), 27452747.

Chu, V.T., Weber, T., Wefers, B., Wurst, W., Sander, S., Rajewsky, K., and Kühn, R., 2015. Increasing the efficiency of homology-directed repair for CRISPRCas9-induced precise gene editing in mammalian cells. Nature Biotechnology, 33 (5), 543-548.

Ciardo, M.G., Andrés-Bordería, A., Cuesta, N., Valente, P., Camprubí-Robles, M., Yang, J., Planells-Cases, R., and Ferrer-Montiel, A., 2016. Whirlin increases TRPV1 channel expression and cellular stability. Biochimica et Biophysica Acta (BBA) - Molecular Cell Research, 1863 (1), 115-127.
Cohen, M., Bitner-Glindzicz, M., and Luxon, L., 2007. The changing face of Usher syndrome: clinical implications. International Journal of Audiology, 46 (2), 82-93.

Collin, J., Zerti, D., Queen, R., Santos-Ferreira, T., Bauer, R., Coxhead, J., Hussain, R., Steel, D., Mellough, C., Ader, M., Sernagor, E., Armstrong, L., and Lako, M., 2019. CRX Expression in Pluripotent Stem Cell-Derived Photoreceptors Marks a Transplantable Subpopulation of Early Cones. Stem Cells (Dayton, Ohio), 37 (5), 609.

Collin, R.W.J. and Garanto, A., 2017. Applications of antisense oligonucleotides for the treatment of inherited retinal diseases. Current Opinion in Ophthalmology, 28 (3), 260-266.

Collin, R.W.J., de Heer, A.-M.R., Oostrik, J., Pauw, R.-J., Plantinga, R.F., Huygen, P.L., Admiraal, R., de Brouwer, A.P.M., Strom, T.M., Cremers, C.W.R.J., and Kremer, H., 2008. Mid-frequency DFNA8/12 hearing loss caused by a synonymous TECTA mutation that affects an exonic splice enhancer. European Journal of Human Genetics, 16 (12), 1430-1436.

Cong, L., Ran, F.A., Cox, D., Lin, S., Barretto, R., Habib, N., Hsu, P.D., Wu, X., Jiang, W., Marraffini, L.A., and Zhang, F., 2013. Multiplex genome engineering using CRISPR/Cas systems. Science (New York, N.Y.), 339 (6121), 819-823.

Coonrod, A., Li, F.Q., and Horwitz, M., 1997. On the mechanism of DNA transfection: efficient gene transfer without viruses. Gene Therapy, 4 (12), 1313-1321.

Coussa, R., Otto, E., Gee, H.-Y., Arthurs, P., Ren, H., Lopez, I., Keser, V., Fu, Q., Faingold, R., Khan, A., Schwartzentruber, J., Majewski, J., Hildebrandtand, F., and Koenekoop, R., 2013. WDR19: An ancient, retrograde, intraflagellar ciliary protein is mutated in autosomal recessive retinitis pigmentosa and in SeniorLoken syndrome. Clinical genetics, 84 (2), 150-159.

Cox, D.B.T., Platt, R.J., and Zhang, F., 2015. Therapeutic Genome Editing: Prospects and Challenges. Nature medicine, 21 (2), 121-131.

Cruchaga, C., Chakraverty, S., Mayo, K., Vallania, F.L.M., Mitra, R.D., Faber, K., Williamson, J., Bird, T., DiazArrastia, R., Foroud, T.M., Boeve, B.F., Graff-Radford, N.R., St. Jean, P., Lawson, M., Ehm, M.G., Mayeux, R., and Goate, A.M., 2012. Rare Variants in APP, PSEN1 and PSEN2 Increase Risk for AD in Late-Onset Alzheimer' $\mathrm{s}$ Disease Families. PLOS ONE, 7 (2).

Crudele, J.M. and Chamberlain, J.S., 2018. Cas9 immunity creates challenges for CRISPR gene editing therapies. Nature Communications, 9 (1), 3497. 
da Cruz, L., Dorn, J.D., Humayun, M.S., Dagnelie, G., Handa, J., Barale, P.-O., Sahel, J.-A., Stanga, P.E., Hafezi, F., Safran, A.B., Salzmann, J., Santos, A., Birch, D., Spencer, R., Cideciyan, A.V., de Juan, E., Duncan, J.L., Eliott, D., Fawzi, A., Olmos de Koo, L.C., Ho, A.C., Brown, G., Haller, J., Regillo, C., Del Priore, L.V., Arditi, A., and Greenberg, R.J., 2016. Five-year safety and performance results from the Argus II Retinal Prosthesis System clinical trial. Ophthalmology, 123 (10), 2248-2254.

Cuevas, J.M., Espinós, C., Millán, J.M., Sánchez, F., Trujillo, M.J., Ayuso, C., Beneyto, M., and Nájera, C., 1999. Identification of three novel mutations in the MYO7A gene. Human Mutation, 14 (2), 181.

Dabrowski, M., Bukowy-Bieryllo, Z., and Zietkiewicz, E., 2018. Advances in therapeutic use of a drug-stimulated translational readthrough of premature termination codons. Molecular Medicine, 24.

Dad, S., Rendtorff, N.D., Tranebjærg, L., Grønskov, K., Karstensen, H.G., Brox, V., Nilssen, Ø., Roux, A., Rosenberg, T., Jensen, H., and Møller, L.B., 2016. Usher syndrome in Denmark: mutation spectrum and some clinical observations. Molecular Genetics \& Genomic Medicine, 4 (5), 527-539.

Dagdas, Y.S., Chen, J.S., Sternberg, S.H., Doudna, J.A., and Yildiz, A., 2017. A conformational checkpoint between DNA binding and cleavage by CRISPR-Cas9. Science Advances, 3 (8).

Dai, W.-J., Zhu, L.-Y., Yan, Z.-Y., Xu, Y., Wang, Q.-L., and Lu, X.-J., 2016. CRISPR-Cas9 for in vivo Gene Therapy: Promise and Hurdles. Molecular Therapy. Nucleic Acids, 5 (8), e349.

Dalkara, D., Goureau, O., Marazova, K., and Sahel, J.-A., 2016. Let There Be Light: Gene and Cell Therapy for Blindness. Human Gene Therapy, 27 (2), 134-147.

Davenport, S.L.H. and Omenn, G.S., 1977. The heterogeneity of Usher Syndrome, Abstract 215.

Davis, L. and Maizels, N., 2014. Homology-directed repair of DNA nicks via pathways distinct from canonical double-strand break repair. Proceedings of the National Academy of Sciences of the United States of America, 111 (10), E924-E932.

Davis, L. and Maizels, N., 2016. Two Distinct Pathways Support Gene Correction by Single-stranded Donors at DNA Nicks. Cell reports, 17 (7), 1872-1881.

Davydov, E.V., Goode, D.L., Sirota, M., Cooper, G.M., Sidow, A., and Batzoglou, S., 2010. Identifying a High Fraction of the Human Genome to be under Selective Constraint Using GERP++. PLOS Computational Biology, 6 (12), e1001025.

Delarue, M. and Koehl, P., 2018. Combined approaches from physics, statistics, and computer science for ab initio protein structure prediction: ex unitate vires (unity is strength)? F1000Research, 7 .
Delprat, B., Michel, V., Goodyear, R., Yamasaki, Y., Michalski, N., El-Amraoui, A., Perfettini, I., Legrain, P., Richardson, G., Hardelin, J.-P., and Petit, C., 2005. Myosin $\mathrm{XVa}$ and whirlin, two deafness gene products required for hair bundle growth, are located at the stereocilia tips and interact directly. Human Molecular Genetics, 14 (3), 401-410.

Deltcheva, E., Chylinski, K., Sharma, C.M., Gonzales, K., Chao, Y., Pirzada, Z.A., Eckert, M.R., Vogel, J., and Charpentier, E., 2011. CRISPR RNA maturation by transencoded small RNA and host factor RNase III. Nature, 471 (7340), 602-607.

Deluca, A.P., Weed, M.C., Haas, C.M., Halder, J.A., and Stone, E.M., 2015. Apparent Usher Syndrome Caused by the Combination of BBS1-Associated Retinitis Pigmentosa and SLC26A4-Associated Deafness. JAMA ophthalmology, 133 (8), 967-968.

Deng, W.-L., Gao, M.-L., Lei, X.-L., Lv, J.-N., Zhao, H., He, K.W., Xia, X.-X., Li, L.-Y., Chen, Y.-C., Li, Y.-P., Pan, D., Xue, T., and Jin, Z.-B., 2018. Gene Correction Reverses Ciliopathy and Photoreceptor Loss in iPSC-Derived Retinal Organoids from Retinitis Pigmentosa Patients. Stem Cell Reports, 10 (4), 1267-1281.

Desmet, F.-O., Hamroun, D., Lalande, M., Collod-Béroud, G., Claustres, M., and Béroud, C., 2009. Human Splicing Finder: an online bioinformatics tool to predict splicing signals. Nucleic Acids Research, 37 (9), e67.

Dias, M.F., Joo, K., Kemp, J.A., Fialho, S.L., da Silva Cunha, A., Woo, S.J., and Kwon, Y.J., 2018. Molecular genetics and emerging therapies for retinitis pigmentosa: Basic research and clinical perspectives. Progress in Retinal and Eye Research, 63, 107-131.

Dong, C., Wei, P., Jian, X., Gibbs, R., Boerwinkle, E., Wang, K., and Liu, X., 2015. Comparison and integration of deleteriousness prediction methods for nonsynonymous SNVs in whole exome sequencing studies. Human Molecular Genetics, 24 (8), 2125-2137.

Doudna, J.A. and Charpentier, E., 2014. Genome editing. The new frontier of genome engineering with CRISPRCas9. Science (New York, N.Y.), 346 (6213), 1258096.

Dreyer, B., Brox, V., Tranebjaerg, L., Rosenberg, T., Sadeghi, A.M., Möller, C., and Nilssen, O., 2008. Spectrum of USH2A mutations in Scandinavian patients with Usher syndrome type II. Human Mutation, 29 (3), 451.

Dreyer, B., Tranebjaerg, L., Brox, V., Rosenberg, T., Möller, C., Beneyto, M., Weston, M.D., Kimberling, W.J., Cremers, C.W., Liu, X.Z., and Nilssen, O., 2001. A common ancestral origin of the frequent and widespread 2299delG USH2A mutation. American Journal of Human Genetics, 69 (1), 228-234. 
Dreyer, B., Tranebjaerg, L., Rosenberg, T., Weston, M.D., Kimberling, W.J., and Nilssen, O., 2000. Identification of novel USH2A mutations: implications for the structure of USH2A protein. European journal of human genetics: EJHG, 8 (7), 500-506.

Dulon, D., Papal, S., Patni, P., Cortese, M., Vincent, P.F., Tertrais, M., Emptoz, A., Tlili, A., Bouleau, Y., Michel, V., Delmaghani, S., Aghaie, A., Pepermans, E., AlegriaPrevot, O., Akil, O., Lustig, L., Avan, P., Safieddine, S., Petit, C., and El-Amraoui, A., 2018. Clarin-1 gene transfer rescues auditory synaptopathy in model of Usher syndrome. The Journal of Clinical Investigation, 128 (8), 3382-3401.

Eandi, C.M., Dallorto, L., Spinetta, R., Micieli, M.P., Vanzetti, M., Mariottini, A., Passerini, I., Torricelli, F., Alovisi, C., and Marchese, C., 2017. Targeted next generation sequencing in Italian patients with Usher syndrome: phenotype-genotype correlations. Scientific Reports, 7.

Ebermann, I., Phillips, J.B., Liebau, M.C., Koenekoop, R.K., Schermer, B., Lopez, I., Schäfer, E., Roux, A.-F., Dafinger, C., Bernd, A., Zrenner, E., Claustres, M., Blanco, B., Nürnberg, G., Nürnberg, P., Ruland, R., Westerfield, M., Benzing, T., and Bolz, H.J., 2010. PDZD7 is a modifier of retinal disease and a contributor to digenic Usher syndrome. The Journal of Clinical Investigation, 120 (6), 1812-1823.

Ebermann, I., Scholl, H.P.N., Charbel Issa, P., Becirovic, E., Lamprecht, J., Jurklies, B., Millán, J.M., Aller, E., Mitter, D., and Bolz, H., 2007. A novel gene for Usher syndrome type 2: mutations in the long isoform of whirlin are associated with retinitis pigmentosa and sensorineural hearing loss. Human Genetics, 121 (2), 203-211.

Ebrahim, S., Ingham, N.J., Lewis, M.A., Rogers, M.J.C., Cui, R., Kachar, B., Pass, J.C., and Steel, K.P., 2016. Alternative Splice Forms Influence Functions of Whirlin in Mechanosensory Hair Cell Stereocilia. Cell Reports, 15 (5), 935-943.

Eisenberger, T., Di Donato, N., Baig, S.M., Neuhaus, C., Beyer, A., Decker, E., Mürbe, D., Decker, C., Bergmann, C., and Bolz, H.J., 2014. Targeted and genomewide NGS data disqualify mutations in MYO1A, the 'DFNA48 gene' , as a cause of deafness. Human Mutation, 35 (5), 565-570.

Eisenberger, T., Slim, R., Mansour, A., Nauck, M., Nürnberg, G., Nürnberg, P., Decker, C., Dafinger, C., Ebermann, I., Bergmann, C., and Bolz, H.J., 2012. Targeted nextgeneration sequencing identifies a homozygous nonsense mutation in ABHD12, the gene underlying PHARC, in a family clinically diagnosed with Usher syndrome type 3. Orphanet Journal of Rare Diseases, 7, 59.
El-Amraoui, A., Schonn, J.-S., Küssel-Andermann, P., Blanchard, S., Desnos, C., Henry, J.-P., Wolfrum, U., Darchen, F., and Petit, C., 2002. MyRIP, a novel Rab effector, enables myosin VIla recruitment to retinal melanosomes. EMBO reports, 3 (5), 463-470.

Emptoz, A., Michel, V., Lelli, A., Akil, O., Boutet de Monvel, J., Lahlou, G., Meyer, A., Dupont, T., Nouaille, S., Ey, E., Franca de Barros, F., Beraneck, M., Dulon, D., Hardelin, J.P., Lustig, L., Avan, P., Petit, C., and Safieddine, S., 2017. Local gene therapy durably restores vestibular function in a mouse model of Usher syndrome type 1G. Proceedings of the National Academy of Sciences of the United States of America, 114 (36), 9695-9700.

Ettaiche, M., Deval, E., Pagnotta, S., Lazdunski, M., and Lingueglia, E., 2009. Acid-sensing ion channel 3 in retinal function and survival. Investigative Ophthalmology \& Visual Science, 50 (5), 2417-2426.

Ettaiche, M., Guy, N., Hofman, P., Lazdunski, M., and Waldmann, R., 2004. Acid-sensing ion channel 2 is important for retinal function and protects against lightinduced retinal degeneration. The Journal of Neuroscience: The Official Journal of the Society for Neuroscience, 24 (5), 1005-1012.

Eudy, J.D., Weston, M.D., Yao, S., Hoover, D.M., Rehm, H.L., Ma-Edmonds, M., Yan, D., Ahmad, I., Cheng, J.J., Ayuso, C., Cremers, C., Davenport, S., Moller, C., Talmadge, C.B., Beisel, K.W., Tamayo, M., Morton, C.C., Swaroop, A., Kimberling, W.J., and Sumegi, J., 1998. Mutation of a gene encoding a protein with extracellular matrix motifs in Usher syndrome type Ila. Science (New York, N.Y.), 280 (5370), 1753-1757.

Farrar, G.J., Carrigan, M., Dockery, A., Millington-Ward, S., Palfi, A., Chadderton, N., Humphries, M., Kiang, A.S., Kenna, P.F., and Humphries, P., 2017. Toward an elucidation of the molecular genetics of inherited retinal degenerations. Human Molecular Genetics, 26 (R1), R2R11.

Fehrenbach, H., Decker, C., Eisenberger, T., Frank, V., Hampel, T., Walden, U., Amann, K.U., Krüger-Stollfuß, I., Bolz, H.J., Häffner, K., Pohl, M., and Bergmann, C., 2014. Mutations in WDR19 encoding the intraflagellar transport component IFT144 cause a broad spectrum of ciliopathies. Pediatric Nephrology (Berlin, Germany), 29 (8), 1451-1456.

Ferdosi, S.R., Ewaisha, R., Moghadam, F., Krishna, S., Park, J.G., Ebrahimkhani, M.R., Kiani, S., and Anderson, K.S., 2019. Multifunctional CRISPR-Cas9 with engineered immunosilenced human $\mathrm{T}$ cell epitopes. Nature Communications, 10 (1), 1842.

Fernández, A., Josa, S., and Montoliu, L., 2017. A history of genome editing in mammals. Mammalian Genome: Official Journal of the International Mammalian Genome Society, 28 (7-8), 237-246. 
Fokkema, I.F.A.C., Taschner, P.E.M., Schaafsma, G.C.P., Celli, J., Laros, J.F.J., and Dunnen, J.T. den, 2011. LOVD v.2.0: the next generation in gene variant databases. Human Mutation, 32 (5), 557-563.

Fortnum, H.M., Davis, A., Summerfield, A.Q., Marshall, D.H., Davis, A.C., Bamford, J.M., Yoshinaga-Itano, C., and Hind, S., 2001. Prevalence of permanent childhood hearing impairment in the United Kingdom and implications for universal neonatal hearing screening: questionnaire based ascertainment studyCommentary: Universal newborn hearing screening: implications for coordinating and developing services for deaf and hearing impaired children. BMJ, 323 (7312), 536.

Fowler, A., Mahamdallie, S., Ruark, E., Seal, S., Ramsay, E., Clarke, M., Uddin, I., Wylie, H., Strydom, A., Lunter, G., and Rahman, N., 2016. Accurate clinical detection of exon copy number variants in a targeted NGS panel using DECoN. Wellcome Open Research, 1.

Fraefel, C., Mendes-Madeira, A., Mabon, O., Lefebvre, A., Le Meur, G., Ackermann, M., Moullier, P., and Rolling, F., 2005. In vivo gene transfer to the rat retina using herpes simplex virus type 1 (HSV-1)-based amplicon vectors. Gene Therapy, 12 (16), 1283-1288.

Frenzel, H., Bohlender, J., Pinsker, K., Wohlleben, B., Tank, J., Lechner, S.G., Schiska, D., Jaijo, T., Rüschendorf, F., Saar, K., Jordan, J., Millán, J.M., Gross, M., and Lewin, G.R., 2012. A genetic basis for mechanosensory traits in humans. PLoS biology, 10 (5), e1001318.

Fu, Q., Xu, M., Chen, X., Sheng, X., Yuan, Z., Liu, Y., Li, H., Sun, Z., Li, H., Yang, L., Wang, K., Zhang, F., Li, Y., Zhao, C., Sui, $R$., and Chen, R., 2017. CEP78 is mutated in a distinct type of Usher syndrome. Journal of Medical Genetics, 54 (3), 190-195.

Fu, Y., Sander, J.D., Reyon, D., Cascio, V.M., and Joung, J.K., 2014. Improving CRISPR-Cas nuclease specificity using truncated guide RNAs. Nature Biotechnology, 32 (3), 279-284.

Fuster-García, C., García-García, G., Jaijo, T., Blanco-Kelly, F., Tian, L., Hakonarson, H., Ayuso, C., Aller, E., and Millan, J.M., 2019. Expanding the genetic landscape of Usherlike phenotypes. Investigative Ophthalmology \& Visual Science, (In Press).

Fuster-García, C., García-García, G., Jaijo, T., Fornés, N., Ayuso, C., Fernández-Burriel, M., Morena, A.S.-D. la, Aller, E., and Millán, J.M., 2018. High-throughput sequencing for the molecular diagnosis of Usher syndrome reveals 42 novel mutations and consolidates CEP250 as Usher-like disease causative. Scientific Reports, 8 (1), 17113.

Gagliardi, G., Ben M' Barek, K., and Goureau, O., 2019. Photoreceptor cell replacement in macular degeneration and retinitis pigmentosa: A pluripotent stem cell-based approach. Progress in Retinal and Eye Research.
Gao, X., Tao, Y., Lamas, V., Huang, M., Yeh, W.-H., Pan, B., Hu, Y.-J., Hu, J.H., Thompson, D.B., Shu, Y., Li, Y., Wang, H., Yang, S., Xu, Q., Polley, D.B., Liberman, M.C., Kong, W.-J., Holt, J.R., Chen, Z.-Y., and Liu, D.R., 2018. Treatment of autosomal dominant hearing loss by in vivo delivery of genome editing agents. Nature, 553 (7687), 217-221.

Garber, M., Guttman, M., Clamp, M., Zody, M.C., Friedman, $\mathrm{N}$., and Xie, X., 2009. Identifying novel constrained elements by exploiting biased substitution patterns. Bioinformatics, 25 (12), i54-i62.

García-García, G., Aller, E., Jaijo, T., Aparisi, M.J., Larrieu, L., Faugère, V., Blanco-Kelly, F., Ayuso, C., Roux, A.-F., and Millán, J.M., 2014. Novel deletions involving the USH2A gene in patients with Usher syndrome and retinitis pigmentosa. Molecular Vision, 20, 1398-1410.

Garcia-Garcia, G., Aparisi, M.J., Jaijo, T., Rodrigo, R., Leon, A.M., Avila-Fernandez, A., Blanco-Kelly, F., Bernal, S., Navarro, R., Diaz-Llopis, M., Baiget, M., Ayuso, C., Millan, J.M., and Aller, E., 2011. Mutational screening of the USH2A gene in Spanish USH patients reveals 23 novel pathogenic mutations. Orphanet Journal of Rare Diseases, 6, 65 .

Gasparini, S.J., Llonch, S., Borsch, O., and Ader, M., 2019. Transplantation of photoreceptors into the degenerative retina: Current state and future perspectives. Progress in Retinal and Eye Research, 69, $1-37$

Géléoc, G.S.G. and Holt, J.R., 2014. Sound Strategies for Hearing Restoration. Science (New York, N.Y.), 344 (6184), 1241062

Geng, R., Geller, S.F., Hayashi, T., Ray, C.A., Reh, T.A., Bermingham-McDonogh, O., Jones, S.M., Wright, C.G., Melki, S., Imanishi, Y., Palczewski, K., Alagramam, K.N., and Flannery, J.G., 2009. Usher syndrome IIIA gene clarin-1 is essential for hair cell function and associated neural activation. Human Molecular Genetics, 18 (15), $2748-2760$

Geng, R., Omar, A., Gopal, S.R., Chen, D.H.-C., Stepanyan, R., Basch, M.L., Dinculescu, A., Furness, D.N., Saperstein, D., Hauswirth, W., Lustig, L.R., and Alagramam, K.N., 2017. Modeling and Preventing Progressive Hearing Loss in Usher Syndrome III. Scientific Reports, 7 (1), 13480.

Gibbs, D., Diemer, T., Khanobdee, K., Hu, J., Bok, D., and Williams, D.S., 2010. Function of MYO7A in the human RPE and the validity of shaker1 mice as a model for Usher syndrome 1B. Investigative Ophthalmology \& Visual Science, 51 (2), 1130-1135.

Gibbs, D., Kitamoto, J., and Williams, D.S., 2003. Abnormal phagocytosis by retinal pigmented epithelium that lacks myosin VIla, the Usher syndrome 1B protein. Proceedings of the National Academy of Sciences of the United States of America, 100 (11), 6481-6486. 
Giese, A.P.J., Tang, Y.-Q., Sinha, G.P., Bowl, M.R., Goldring, A.C., Parker, A., Freeman, M.J., Brown, S.D.M., Riazuddin, S., Fettiplace, R., Schafer, W.R., Frolenkov, G.l., and Ahmed, Z.M., 2017. CIB2 interacts with TMC1 and TMC2 and is essential for mechanotransduction in auditory hair cells. Nature Communications, 8.

Goldmann, T., Overlack, N., Möller, F., Belakhov, V., van Wyk, M., Baasov, T., Wolfrum, U., and Nagel-Wolfrum, K., 2012. A comparative evaluation of NB30, NB54 and PTC124 in translational read-through efficacy for treatment of an USH1C nonsense mutation. EMBO Molecular Medicine, 4 (11), 1186-1199.

Goldmann, T., Overlack, N., Wolfrum, U., and NagelWolfrum, K., 2011. PTC124-mediated translational readthrough of a nonsense mutation causing Usher syndrome type 1C. Human Gene Therapy, 22 (5), 537547.

Gong, C., Bongiorno, P., Martins, A., Stephanou, N.C., Zhu, H., Shuman, S., and Glickman, M.S., 2005. Mechanism of nonhomologous end-joining in mycobacteria: a lowfidelity repair system driven by $\mathrm{Ku}$, ligase $\mathrm{D}$ and ligase $\mathrm{C}$. Nature Structural \& Molecular Biology, 12 (4), 304-312.

Gonzalez-Cordero, A., West, E.L., Pearson, R.A., Duran, Y., Carvalho, L.S., Chu, C.J., Naeem, A., Blackford, S.J.l., Georgiadis, A., Lakowski, J., Hubank, M., Smith, A.J., Bainbridge, J.W.B., Sowden, J.C., and Ali, R.R., 2013. Photoreceptor precursors derived from threedimensional embryonic stem cell cultures integrate and mature within adult degenerate retina. Nature Biotechnology, 31 (8), 741-747.

Gopal, S.R., Lee, Y.T., Stepanyan, R., McDermott, B.M., and Alagramam, K.N., 2019. Unconventional secretory pathway activation restores hair cell mechanotransduction in an USH3A model. Proceedings of the National Academy of Sciences of the United States of America, 116 (22), 11000-11009.

Goyal, N. and Narayanaswami, P., 2018. Making sense of antisense oligonucleotides: A narrative review. Muscle \& Nerve, 57 (3), 356-370.

von Gräfe, A., 1858. Exceptionelles Verhalten des Gesichtsfeldes bei Pigmententartung der Netzhaut. Archiv für Ophthalmologie, 4, 250-253.

Grati, M. and Kachar, B., 2011. Myosin VIla and sans localization at stereocilia upper tip-link density implicates these Usher syndrome proteins in mechanotransduction. Proceedings of the National Academy of Sciences of the United States of America, 108 (28), 11476-11481.

Grijalvo, S., Puras, G., Zárate, J., Sainz-Ramos, M., Qtaish, N.A.L., López, T., Mashal, M., Attia, N., Díaz Díaz, D., Pons, R., Fernández, E., Pedraz, J.L., and Eritja, R., 2019. Cationic Niosomes as Non-Viral Vehicles for Nucleic Acids: Challenges and Opportunities in Gene Delivery. Pharmaceutics, 11 (2).
Grillet, N., Xiong, W., Reynolds, A., Kazmierczak, P., Sato, T., Lillo, C., Dumont, R.A., Hintermann, E., Sczaniecka, A., Schwander, M., Williams, D., Kachar, B., Gillespie, P.G., and Müller, U., 2009. Harmonin mutations cause mechanotransduction defects in cochlear hair cells. Neuron, 62 (3), 375-387.

Grobarczyk, B., Franco, B., Hanon, K., and Malgrange, B., 2015. Generation of Isogenic Human iPS Cell Line Precisely Corrected by Genome Editing Using the CRISPR/Cas9 System. Stem Cell Reviews, 11 (5), 774787.

Guadagni, V., Novelli, E., Piano, I., Gargini, C., and Strettoi, E., 2015. Pharmacological approaches to retinitis pigmentosa: A laboratory perspective. Progress in Retinal and Eye Research, 48, 62-81.

Gurgel, R.K., Ward, P.D., Schwartz, S., Norton, M.C., Foster, N.L., and Tschanz, J.T., 2014. Relationship of Hearing loss and Dementia: a Prospective, Population-based Study. Otology \& neurotology: official publication of the American Otological Society, American Neurotology Society [and] European Academy of Otology and Neurotology, 35 (5), 775-781.

Guschin, D.Y., Waite, A.J., Katibah, G.E., Miller, J.C., Holmes, M.C., and Rebar, E.J., 2010. A rapid and general assay for monitoring endogenous gene modification. Methods in Molecular Biology (Clifton, N.J.), 649, 247-256.

György, B., Meijer, E.J., Ivanchenko, M.V., Tenneson, K., Emond, F., Hanlon, K.S., Indzhykulian, A.A., Volak, A., Karavitaki, K.D., Tamvakologos, P.I., Vezina, M., Berezovskii, V.K., Born, R.T., O' Brien, M., Lafond, J.-F., Arsenijevic, Y., Kenna, M.A., Maguire, C.A., and Corey, D.P., 2019. Gene Transfer with AAV9-PHP.B Rescues Hearing in a Mouse Model of Usher Syndrome $3 A$ and Transduces Hair Cells in a Non-human Primate. Molecular Therapy. Methods \& Clinical Development, 13, 1-13.

Han, C., Sun, X., Liu, L., Jiang, H., Shen, Y., Xu, X., Li, J., Zhang, G., Huang, J., Lin, Z., Xiong, N., and Wang, T., 2016. Exosomes and Their Therapeutic Potentials of Stem Cells. Stem Cells International, 2016.

Hanukoglu, I., 2017. ASIC and ENaC type sodium channels: conformational states and the structures of the ion selectivity filters. The FEBS journal, 284 (4), 525-545.

Hardy, C.J.D., Marshall, C.R., Golden, H.L., Clark, C.N., Mummery, C.J., Griffiths, T.D., Bamiou, D.-E., and Warren, J.D., 2016. Hearing and dementia. Journal of Neurology, 263 (11), 2339-2354.

Hartong, D.T., Berson, E.L., and Dryja, T.P., 2006. Retinitis pigmentosa. Lancet (London, England), 368 (9549), 1795-1809. 
Hashimoto, T., Gibbs, D., Lillo, C., Azarian, S.M., Legacki, E., Zhang, X.-M., Yang, X.-J., and Williams, D.S., 2007. Lentiviral gene replacement therapy of retinas in a mouse model for Usher syndrome type 1B. Gene Therapy, 14 (7), 584-594.

Heyer, W.-D., Ehmsen, K.T., and Liu, J., 2010. Regulation of homologous recombination in eukaryotes. Annual Review of Genetics, 44, 113-139.

Hibbitt, O.C. and Wade-Martins, R., 2006. Delivery of large genomic DNA inserts $>100 \mathrm{~kb}$ using HSV-1 amplicons. Current Gene Therapy, 6 (3), 325-336.

Hildebrand, M.S., Morín, M., Meyer, N.C., Mayo, F., Modamio-Hoybjor, S., Mencía, A., Olavarrieta, L., Morales-Angulo, C., Nishimura, C.J., Workman, $H_{\text {., }}$ DeLuca, A.P., Castillo, I. del, Taylor, K.R., Tompkins, B., Goodman, C.W., Schrauwen, I., Wesemael, M.V., Lachlan, K., Shearer, A.E., Braun, T.A., Huygen, P.L.M., Kremer, H., Camp, G.V., Moreno, F., Casavant, T.L., Smith, R.J.H., and Moreno-Pelayo, M.A., 2011. DFNA8/12 Caused by TECTA Mutations is the Most Identified Subtype of Nonsyndromic Autosomal Dominant Hearing Loss. Human Mutation, 32 (7), 825

Hodgkins, A., Farne, A., Perera, S., Grego, T., Parry-Smith, D.J., Skarnes, W.C., and lyer, V., 2015. WGE: a CRISPR database for genome engineering. Bioinformatics, 31 (18), 3078-3080.

Hoefsloot, L.H., Feenstra, I., Kunst, H.P.M., and Kremer, H., 2014. Genotype phenotype correlations for hearing impairment: approaches to management. Clinical Genetics, 85 (6), 514-523.

Holme, R.H., Kiernan, B.W., Brown, S.D.M., and Steel, K.P., 2002. Elongation of hair cell stereocilia is defective in the mouse mutant whirler. The Journal of Comparative Neurology, 450 (1), 94-102.

Homma, K., Okamoto, S., Mandai, M., Gotoh, N., Rajasimha, H.K., Chang, Y.-S., Chen, S., Li, W., Cogliati, T., Swaroop, A., and Takahashi, M., 2013. Developing Rods Transplanted into the Degenerating Retina of CrxKnockout Mice Exhibit Neural Activity Similar to Native Photoreceptors. STEM CELLS, 31 (6), 1149-1159.

Hoshino, A.C.H., Echegoyen, A., Goffi-Gomez, M.V.S., Tsuji, R.K., and Bento, R.F., 2017. Outcomes of Late Implantation in Usher Syndrome Patients. International Archives of Otorhinolaryngology, 21 (2), 140-143.

Hsiung, G.-Y.R. and Feldman, H.H., 1993. GRN-Related Frontotemporal Dementia. Ir. M.P. Adam, H.H. Ardinger, R.A. Pagon, S.E. Wallace, L.J. Bean, K. Stephens, and A. Amemiya, eds. GeneReviews $\AA$. Seattle (WA): University of Washington, Seattle.

Hsu, P.D., Lander, E.S., and Zhang, F., 2014. Development and applications of CRISPR-Cas9 for genome engineering. Cell, 157 (6), 1262-1278.
Hu, Z. and Ulfendahl, M., 2013. The potential of stem cells for the restoration of auditory function in humans. Regenerative medicine, 8 (3), 309-318.

Huang, D., Chen, Y.-S., and Rupenthal, I.D., 2017. Hyaluronic Acid Coated Albumin Nanoparticles for Targeted Peptide Delivery to the Retina. Molecular Pharmaceutics.

Huang, X.-F., Xiang, P., Chen, J., Xing, D.-J., Huang, N., Min, Q., Gu, F., Tong, Y., Pang, C.-P., Qu, J., and Jin, Z.-B., 2013. Targeted Exome Sequencing Identified Novel USH2A Mutations in Usher Syndrome Families. PLOS ONE, 8 (5).

Hull, S., Attanasio, M., Arno, G., Carss, K., Robson, A.G., Thompson, D.A., Plagnol, V., Michaelides, M., Holder, G.E., Henderson, R.H., Raymond, F.L., Moore, A.T., and Webster, A.R., 2017. Clinical Characterization of CNGB1Related Autosomal Recessive Retinitis Pigmentosa. JAMA ophthalmology, 135 (2), 137-144.

Hunter, D.G., Fishman, G.A., Mehta, R.S., and Kretzer, F.L., 1986. Abnormal sperm and photoreceptor axonemes in Usher's syndrome. Archives of Ophthalmology (Chicago, III.: 1960), 104 (3), 385-389.

Inoue, A. and Ikebe, M., 2003. Characterization of the motor activity of mammalian myosin VIIA. The Journal of Biological Chemistry, 278 (7), 5478-5487.

Isgrig, K., Shteamer, J.W., Belyantseva, I.A., Drummond, M.C., Fitzgerald, T.S., Vijayakumar, S., Jones, S.M., Griffith, A.J., Friedman, T.B., Cunningham, L.L., and Chien, W.W., 2017. Gene Therapy Restores Balance and Auditory Functions in a Mouse Model of Usher Syndrome. Molecular Therapy, 25 (3), 780-791.

Ivanova, M.E., Trubilin, V.N., Atarshchikov, D.S., Demchinsky, A.M., Strelnikov, V.V., Tanas, A.S., Orlova, O.M., Machalov, A.S., Overchenko, K.V., Markova, T.V., Golenkova, D.M., Anoshkin, K.I., Volodin, I.V., Zaletaev, D.V., Pulin, A.A., Nadelyaeva, I.I., Kalinkin, A.I., and Barh, D., 2018. Genetic screening of Russian Usher syndrome patients toward selection for gene therapy. Ophthalmic Genetics, 39 (6), 706-713.

Jacobson, S.G., Aleman, T.S., Sumaroka, A., Cideciyan, A.V., Roman, A.J., Windsor, E.A.M., Schwartz, S.B., Rehm, H.L., and Kimberling, W.J., 2009. Disease boundaries in the retina of patients with Usher syndrome caused by MYO7A gene mutations. Investigative Ophthalmology \& Visual Science, 50 (4), 1886-1894.

Jacoszek, A., Pollak, A., Płoski, R., and Ołdak, M., 2017. Advances in genetic hearing loss: $\mathrm{ClB} 2$ gene. European Archives of Oto-Rhino-Laryngology, 274 (4), 17911795.

Jaiganesh, A., Narui, Y., Araya-Secchi, R., and Sotomayor, M., 2018. Beyond Cell-Cell Adhesion: Sensational Cadherins for Hearing and Balance. Cold Spring Harbor Perspectives in Biology, 10 (9). 
Jaijo, T., Aller, E., Beneyto, M., Najera, C., Graziano, C., Turchetti, D., Seri, M., Ayuso, C., Baiget, M., Moreno, F., Morera, C., Perez-Garrigues, H., and Millan, J.M., 2007. MYO7A mutation screening in Usher syndrome type I patients from diverse origins. Journal of Medical Genetics, 44 (3), e71-e71.

Jaijo, T., Aller, E., García-García, G., Aparisi, M.J., Bernal, S., Avila-Fernández, A., Barragán, I., Baiget, M., Ayuso, C., Antiñolo, G., Díaz-Llopis, M., Külm, M., Beneyto, M., Nájera, C., and Millán, J.M., 2010. Microarray-based mutation analysis of 183 Spanish families with Usher syndrome. Investigative Ophthalmology \& Visual Science, 51 (3), 1311-1317.

Jaijo, T., Oshima, A., Aller, E., Carney, C., Usami, S., Millán, J.M., and Kimberling, W.J., 2012. Mutation screening of the PCDH15 gene in Spanish patients with Usher syndrome type I. Molecular Vision, 18, 1719-1726.

Jain, P.K., Lalwani, A.K., Li, X.C., Singleton, T.L., Smith, T.N., Chen, A., Deshmukh, D., Verma, I.C., Smith, R.J., and Wilcox, E.R., 1998. A gene for recessive nonsyndromic sensorineural deafness (DFNB18) maps to the chromosomal region 11p14-p15.1 containing the Usher syndrome type 1C gene. Genomics, 50 (2), 290-292.

Jayathilaka, K., Sheridan, S.D., Bold, T.D., Bochenska, K., Logan, H.L., Weichselbaum, R.R., Bishop, D.K., and Connell, P.P., 2008. A chemical compound that stimulates the human homologous recombination protein RAD51. Proceedings of the National Academy of Sciences of the United States of America, 105 (41), 15848-15853.

Jia, Y., Li, X., Yang, D., Xu, Y., Guo, Y., and Li, X., 2018. Identification of two novel pathogenic compound heterozygous MYO7A mutations in Usher syndrome by whole exome sequencing. International Journal of Pediatric Otorhinolaryngology, 104, 186-190.

Jiang, L., Liang, X., Li, Y., Wang, J., Zaneveld, J.E., Wang, H., Xu, S., Wang, K., Wang, B., Chen, R., and Sui, R., 2015. Comprehensive molecular diagnosis of 67 Chinese Usher syndrome probands: high rate of ethnicity specific mutations in Chinese USH patients. Orphanet Journal of Rare Diseases, 10, 110.

Jinek, M., Chylinski, K., Fonfara, I., Hauer, M., Doudna, J.A., and Charpentier, E., 2012. A programmable dual-RNAguided DNA endonuclease in adaptive bacterial immunity. Science (New York, N.Y.), 337 (6096), 816821.

Joensuu, T., Hämäläinen, R., Yuan, B., Johnson, C., Tegelberg, S., Gasparini, P., Zelante, L., Pirvola, U., Pakarinen, L., Lehesjoki, A.E., de la Chapelle, A., and Sankila, E.M., 2001. Mutations in a novel gene with transmembrane domains underlie Usher syndrome type 3. American Journal of Human Genetics, 69 (4), 673-684.
Jouret, G., Poirsier, C., Spodenkiewicz, M., Jaquin, C., Gouy, E., Arndt, C., Labrousse, M., Gaillard, D., Doco-Fenzy, M., and Lebre, A.-S., 2019. Genetics of Usher Syndrome: New Insights From a Meta-analysis. Otology \& Neurotology: Official Publication of the American Otological Society, American Neurotology Society [and] European Academy of Otology and Neurotology, 40 (1), 121-129.

Kalay, E., de Brouwer, A.P.M., Caylan, R., Nabuurs, S.B., Wollnik, B., Karaguzel, A., Heister, J.G.A.M., Erdol, H., Cremers, F.P.M., Cremers, C.W.R.J., Brunner, H.G., and Kremer, H., 2005. A novel D458V mutation in the SANS PDZ binding motif causes atypical Usher syndrome. Journal of Molecular Medicine, 83 (12), 1025-1032.

Kanzaki, S., 2018. Gene Delivery into the Inner Ear and Its Clinical Implications for Hearing and Balance. Molecules: A Journal of Synthetic Chemistry and Natural Product Chemistry, 23 (10).

Kazmierczak, P., Sakaguchi, H., Tokita, J., Wilson-Kubalek, E.M., Milligan, R.A., Müller, U., and Kachar, B., 2007. Cadherin 23 and protocadherin 15 interact to form tiplink filaments in sensory hair cells. Nature, 449 (7158), 87-91.

Kelley, P.M., Weston, M.D., Chen, Z.Y., Orten, D.J., Hasson, T., Overbeck, L.D., Pinnt, J., Talmadge, C.B., Ing, P., Mooseker, M.S., Corey, D., Sumegi, J., and Kimberling, W.J., 1997. The genomic structure of the gene defective in Usher syndrome type Ib (MYO7A). Genomics, 40 (1), 73-79.

Kersten, F.F.J., van Wijk, E., van Reeuwijk, J., van der Zwaag, B., Märker, T., Peters, T.A., Katsanis, N., Wolfrum, U., Keunen, J.E.E., Roepman, R., and Kremer, H., 2010. Association of whirlin with Cav1.3 (alpha1D) channels in photoreceptors, defining a novel member of the usher protein network. Investigative Ophthalmology \& Visual Science, 51 (5), 2338-2346.

Khan, A.O., Becirovic, E., Betz, C., Neuhaus, C., Altmüller, J., Riedmayr, L.M., Motameny, S., Nürnberg, G., Nürnberg, P., and Bolz, H.J., 2017. A deep intronic CLRN1 ( USH3A) founder mutation generates an aberrant exon and underlies severe Usher syndrome on the Arabian Peninsula. Scientific Reports, 7 (1), 1411.

Khani, S.C., Pawlyk, B.S., Bulgakov, O.V., Kasperek, E., Young, J.E., Adamian, M., Sun, X., Smith, A.J., Ali, R.R., and $\mathrm{Li}, \mathrm{T} ., 2007$. AAV-mediated expression targeting of rod and cone photoreceptors with a human rhodopsin kinase promoter. Investigative Ophthalmology \& Visual Science, 48 (9), 3954-3961.

Khateb, S., Kowalewski, B., Bedoni, N., Damme, M., Pollack, N., Saada, A., Obolensky, A., Ben-Yosef, T., Gross, M., Dierks, T., Banin, E., Rivolta, C., and Sharon, D., 2018. A homozygous founder missense variant in arylsulfatase $G$ abolishes its enzymatic activity causing atypical Usher syndrome in humans. Genetics in Medicine: Official Journal of the American College of Medical Genetics, 20 (9), 1004-1012. 
Khateb, S., Zelinger, L., Ben-Yosef, T., Merin, S., CrystalShalit, O., Gross, M., Banin, E., and Sharon, D., 2012. Exome Sequencing Identifies a Founder Frameshift Mutation in an Alternative Exon of USH1C as the Cause of Autosomal Recessive Retinitis Pigmentosa with LateOnset Hearing Loss. PLOS ONE, 7 (12).

Khateb, S., Zelinger, L., Mizrahi-Meissonnier, L., Ayuso, C., Koenekoop, R.K., Laxer, U., Gross, M., Banin, E., and Sharon, D., 2014. A homozygous nonsense CEP250 mutation combined with a heterozygous nonsense C2orf71 mutation is associated with atypical Usher syndrome. Journal of Medical Genetics, 51 (7), 460-469.

Kikkawa, Y., Mburu, P., Morse, S., Kominami, R., Townsend, S., and Brown, S.D.M., 2005. Mutant analysis reveals whirlin as a dynamic organizer in the growing hair cell stereocilium. Human Molecular Genetics, 14 (3), 391400.

Kim, H.J., Lee, H.J., Kim, H., Cho, S.W., and Kim, J.-S., 2009. Targeted genome editing in human cells with zinc finger nucleases constructed via modular assembly. Genome Research, 19 (7), 1279-1288.

Kim, N.K.D., Kim, A.R., Park, K.T., Kim, S.Y., Kim, M.Y., Nam, J.-Y., Woo, S.J., Oh, S.-H., Park, W.-Y., and Choi, B.Y., 2015. Whole-exome sequencing reveals diverse modes of inheritance in sporadic mild to moderate sensorineural hearing loss in a pediatric population. Genetics in Medicine: Official Journal of the American College of Medical Genetics, 17 (11), 901-911.

Kim, S., Kim, D., Cho, S.W., Kim, J., and Kim, J.-S., 2014. Highly efficient RNA-guided genome editing in human cells via delivery of purified Cas9 ribonucleoproteins. Genome Research, 24 (6), 1012-1019.

Kimberling, W.J., Möller, C.G., Davenport, S., Priluck, I.A., Beighton, P.H., Greenberg, J., Reardon, W., Weston, M.D., Kenyon, J.B., and Grunkemeyer, J.A., 1992. Linkage of Usher syndrome type I gene (USH1B) to the long arm of chromosome 11. Genomics, 14 (4), 988-994.

Kimberling, W.J., Weston, M.D., Möller, C., van Aarem, A., Cremers, C.W., Sumegi, J., Ing, P.S., Connolly, C., Martini, A., and Milani, M., 1995. Gene mapping of Usher syndrome type lla: localization of the gene to a 2.1-cM segment on chromosome 1q41. American Journal of Human Genetics, 56 (1), 216-223.

Kimberling, W.J., Weston, M.D., Möller, C., Davenport, S.L., Shugart, Y.Y., Priluck, I.A., Martini, A., Milani, M., and Smith, R.J., 1990. Localization of Usher syndrome type II to chromosome 1q. Genomics, 7 (2), 245-249.

Kleinstiver, B.P., Pattanayak, V., Prew, M.S., Tsai, S.Q., Nguyen, N.T., Zheng, Z., and Joung, J.K., 2016. Highfidelity CRISPR-Cas9 nucleases with no detectable genome-wide off-target effects. Nature, 529 (7587), 490-495.
Kooshavar, D., Razipour, M., Movasat, M., and Keramatipour, M., 2018. Targeted next generation sequencing identified a novel mutation in MYO7A causing Usher syndrome type 1 in an Iranian consanguineous pedigree. International Journal of Pediatric Otorhinolaryngology, 104, 10-13.

Koparir, A., Karatas, O.F., Atayoglu, A.T., Yuksel, B., Sagiroglu, M.S., Seven, M., Ulucan, H., Yuksel, A., and Ozen, M., 2015. Whole-exome sequencing revealed two novel mutations in Usher syndrome. Gene, 563 (2), 215218.

Kouranova, E., Forbes, K., Zhao, G., Warren, J., Bartels, A., Wu, Y., and Cui, X., 2016. CRISPRs for Optimal Targeting: Delivery of CRISPR Components as DNA, RNA, and Protein into Cultured Cells and Single-Cell Embryos. Human Gene Therapy, 27 (6), 464-475.

Krawitz, P.M., Schiska, D., Krüger, U., Appelt, S., Heinrich, V., Parkhomchuk, D., Timmermann, B., Millan, J.M., Robinson, P.N., Mundlos, S., Hecht, J., and Gross, M., 2014. Screening for single nucleotide variants, small indels and exon deletions with a next-generation sequencing based gene panel approach for Usher syndrome. Molecular Genetics \& Genomic Medicine, 2 (5), 393-401.

Kros, C.J., Marcotti, W., van Netten, S.M., Self, T.J., Libby, R.T., Brown, S.D.M., Richardson, G.P., and Steel, K.P., 2002. Reduced climbing and increased slipping adaptation in cochlear hair cells of mice with Myo7a mutations. Nature Neuroscience, 5 (1), 41-47.

Kubota, D., Gocho, K., Kikuchi, S., Akeo, K., Miura, M., Yamaki, K., Takahashi, H., and Kameya, S., 2018. CEP250 mutations associated with mild cone-rod dystrophy and sensorineural hearing loss in a Japanese family. Ophthalmic Genetics, 1-8.

Kumar, A., Fishman, G., and Torok, N., 1984. Vestibular and auditory function in Usher' s syndrome. The Annals of Otology, Rhinology, and Laryngology, 93 (6 Pt 1), 600608.

Kumar, P., Henikoff, S., and Ng, P.C., 2009. Predicting the effects of coding non-synonymous variants on protein function using the SIFT algorithm. Nature Protocols, 4 (7), 1073-1081.

Kumar-Singh, R., 2008. Barriers for retinal gene therapy: Separating fact from fiction. Vision Research, 48 (16), 1671-1680.

Lamba, D.A., Gust, J., and Reh, T.A., 2009. Transplantation of human embryonic stem cell-derived photoreceptors restores some visual function in $\mathrm{Crx}$-deficient mice. Cell Stem Cell, 4 (1), 73-79. 
Landrum, M.J., Lee, J.M., Benson, M., Brown, G.R., Chao, C., Chitipiralla, S., Gu, B., Hart, J., Hoffman, D., Jang, W., Karapetyan, K., Katz, K., Liu, C., Maddipatla, Z., Malheiro, A., McDaniel, K., Ovetsky, M., Riley, G., Zhou, G., Holmes, J.B., Kattman, B.L., and Maglott, D.R., 2018. ClinVar: improving access to variant interpretations and supporting evidence. Nucleic Acids Research, 46 (D1), D1062-D1067.

Latella, M.C., Salvo, M.T.D., Cocchiarella, F., Benati, D., Grisendi, G., Comitato, A., Marigo, V., and Recchia, A., 2016. In vivo Editing of the Human Mutant Rhodopsin Gene by Electroporation of Plasmid-based CRISPR/Cas9 in the Mouse Retina. Molecular Therapy - Nucleic Acids, 5.

Le Quesne Stabej, P., Saihan, Z., Rangesh, N., SteeleStallard, H.B., Ambrose, J., Coffey, A., Emmerson, J., Haralambous, E., Hughes, Y., Steel, K.P., Luxon, L.M., Webster, A.R., and Bitner-Glindzicz, M., 2012. Comprehensive sequence analysis of nine Usher syndrome genes in the UK National Collaborative Usher Study. Journal of Medical Genetics, 49 (1), 27-36.

Lee, J., Goh, U., Lee, H.-J., Kim, J., Jeong, M., and Park, J.-H., 2016. Effective Retinal Penetration of Lipophilic and Lipid-Conjugated Hydrophilic Agents Delivered by Engineered Liposomes. Molecular Pharmaceutics.

Lee, J., Wu, S., and Zhang, Y., 2009. Ab Initio Protein Structure Prediction. In. D.J. Rigden, ed. From Protein Structure to Function with Bioinformatics. Dordrecht: Springer Netherlands, 3-25.

Lee, M.Y. and Park, Y.-H., 2018. Potential of Gene and Cell Therapy for Inner Ear Hair Cells. BioMed Research International, 2018, 8137614.

Lenarduzzi, S., Vozzi, D., Morgan, A., Rubinato, E., D' Eustacchio, A., Osland, T.M., Rossi, C., Graziano, C., Castorina, P., Ambrosetti, U., Morgutti, M., and Girotto, G., 2015. Usher syndrome: an effective sequencing approach to establish a genetic and clinical diagnosis. Hearing Research, 320, 18-23.

Lenassi, E., Vincent, A., Li, Z., Saihan, Z., Coffey, A.J., SteeleStallard, H.B., Moore, A.T., Steel, K.P., Luxon, L.M., Héon, E., Bitner-Glindzicz, M., and Webster, A.R., 2015. A detailed clinical and molecular survey of subjects with nonsyndromic USH2A retinopathy reveals an allelic hierarchy of disease-causing variants. European Journal of Human Genetics, 23 (10), 1318-1327.

Lentz, J.J., Jodelka, F.M., Hinrich, A.J., McCaffrey, K.E., Farris, H.E., Spalitta, M.J., Bazan, N.G., Duelli, D.M., Rigo, F., and Hastings, M.L., 2013. Rescue of hearing and vestibular function by antisense oligonucleotides in a mouse model of human deafness. Nature Medicine, 19 (3), 345-350.
Lezirovitz, K., Batissoco, A.C., Lima, F.T., Auricchio, M.T.B.M., Nonose, R.W., dos Santos, S.R., Guilherme, L., Oiticica, J., and Mingroni-Netto, R.C., 2012. Aberrant transcript produced by a splice donor site deletion in the TECTA gene is associated with autosomal dominant deafness in a Brazilian family. Gene, 511 (2), 280-284.

Li, H.L., Gee, P., Ishida, K., and Hotta, A., 2016. Efficient genomic correction methods in human iPS cells using CRISPR-Cas9 system. Methods, 101, 27-35.

Li, J., He, Y., Weck, M.L., Lu, Q., Tyska, M.J., and Zhang, M., 2017. Structure of Myo7b/USH1C complex suggests a general PDZ domain binding mode by MyTH4-FERM myosins. Proceedings of the National Academy of Sciences of the United States of America, 114 (19), E3776-E3785.

Li, J., Wang, Y., Zhu, Y., and Oupický, D., 2013. Recent advances in delivery of drug-nucleic acid combinations for cancer treatment. Journal of Controlled Release: Official Journal of the Controlled Release Society, 172 (2), 589-600.

Liang, X., Potter, J., Kumar, S., Zou, Y., Quintanilla, R., Sridharan, M., Carte, J., Chen, W., Roark, N., Ranganathan, S., Ravinder, N., and Chesnut, J.D., 2015. Rapid and highly efficient mammalian cell engineering via Cas9 protein transfection. Journal of Biotechnology, 208, 44-53.

Licastro, D., Mutarelli, M., Peluso, I., Neveling, K., Wieskamp, N., Rispoli, R., Vozzi, D., Athanasakis, E., D' Eustacchio, A., Pizzo, M., D' Amico, F., Ziviello, C., Simonelli, F., Fabretto, A., Scheffer, H., Gasparini, P., Banfi, S., and Nigro, V., 2012. Molecular diagnosis of Usher syndrome: application of two different next generation sequencing-based procedures. PloS One, 7 (8), e43799.

Lin, L., Petersen, T.S., Jensen, K.T., Bolund, L., Kühn, R., and Luo, Y., 2017. Fusion of SpCas9 to E. coli Rec A protein enhances CRISPR-Cas9 mediated gene knockout in mammalian cells. Journal of Biotechnology, 247, 42-49.

Lin, S., Staahl, B.T., Alla, R.K., and Doudna, J.A., 2014a. Enhanced homology-directed human genome engineering by controlled timing of CRISPR/Cas9 delivery. eLife, 3, e04766.

Lin, Y., Cradick, T.J., Brown, M.T., Deshmukh, H., Ranjan, P., Sarode, N., Wile, B.M., Vertino, P.M., Stewart, F.J., and Bao, G., 2014b. CRISPR/Cas9 systems have off-target activity with insertions or deletions between target DNA and guide RNA sequences. Nucleic Acids Research, 42 (11), 7473-7485.

Lino, C.A., Harper, J.C., Carney, J.P., and Timlin, J.A., 2018. Delivering CRISPR: a review of the challenges and approaches. Drug Delivery, 25 (1), 1234-1257. 
Liquori, A., Vaché, C., Baux, D., Blanchet, C., Hamel, C., Malcolm, S., Koenig, M., Claustres, M., and Roux, A.-F., 2016. Whole USH2A Gene Sequencing Identifies Several New Deep Intronic Mutations. Human Mutation, 37 (2), 184-193.

Liu, H., Han, H., Li, J., and Wong, L., 2005. DNAFSMiner: a web-based software toolbox to recognize two types of functional sites in DNA sequences. Bioinformatics (Oxford, England), 21 (5), 671-673.

Liu, L., Li, Y., Li, S., Hu, N., He, Y., Pong, R., Lin, D., Lu, L., and Law, M., 2012. Comparison of Next-Generation Sequencing Systems. Journal of Biomedicine and Biotechnology, 2012.

Liu, M., Rehman, S., Tang, X., Gu, K., Fan, Q., Chen, D., and $M a$, W., 2019. Methodologies for Improving HDR Efficiency. Frontiers in Genetics, 9.

Liu, X., Bulgakov, O.V., Darrow, K.N., Pawlyk, B., Adamian, M., Liberman, M.C., and Li, T., 2007. Usherin is required for maintenance of retinal photoreceptors and normal development of cochlear hair cells. Proceedings of the National Academy of Sciences of the United States of America, 104 (11), 4413-4418.

Liu, X., Udovichenko, I.P., Brown, S.D., Steel, K.P., and Williams, D.S., 1999a. Myosin VIla participates in opsin transport through the photoreceptor cilium. The Journal of Neuroscience: The Official Journal of the Society for Neuroscience, 19 (15), 6267-6274.

Liu, X.Z., Hope, C., Liang, C.Y., Zou, J.M., Xu, L.R., Cole, T., Mueller, R.F., Bundey, S., Nance, W., Steel, K.P., and Brown, S.D., 1999b. A mutation (2314delG) in the Usher syndrome type IIA gene: high prevalence and phenotypic variation. American Journal of Human Genetics, 64 (4), 1221-1225.

Liu, X.Z., Hope, C., Walsh, J., Newton, V., Ke, X.M., Liang, C.Y., Xu, L.R., Zhou, J.M., Trump, D., Steel, K.P., Bundey, S., and Brown, S.D., 1998. Mutations in the myosin VIIA gene cause a wide phenotypic spectrum, including atypical Usher syndrome. American Journal of Human Genetics, 63 (3), 909-912.

Loman, N.J., Misra, R.V., Dallman, T.J., Constantinidou, C., Gharbia, S.E., Wain, J., and Pallen, M.J., 2012. Performance comparison of benchtop high-throughput sequencing platforms. Nature Biotechnology, 30 (5), 434-439.

Long, C., Amoasii, L., Mireault, A.A., McAnally, J.R., Li, H., Sanchez-Ortiz, E., Bhattacharyya, S., Shelton, J.M., Bassel-Duby, R., and Olson, E.N., 2016. Postnatal genome editing partially restores dystrophin expression in a mouse model of muscular dystrophy. Science (New York, N.Y.), 351 (6271), 400-403.
Lopes, V.S., Boye, S.E., Louie, C.M., Boye, S., Dyka, F., Chiodo, V., Fofo, H., Hauswirth, W.W., and Williams, D.S., 2013. Retinal gene therapy with a large MYO7A CDNA using adeno-associated virus. Gene therapy, 20 (8), 824-833.

Lopes, V.S. and Williams, D.S., 2015. Gene Therapy for the Retinal Degeneration of Usher Syndrome Caused by Mutations in MYO7A. Cold Spring Harbor Perspectives in Medicine, 5 (6).

Loundon, N., Marlin, S., Busquet, D., Denoyelle, F., Roger, G., Renaud, F., and Garabedian, E.N., 2003. Usher syndrome and cochlear implantation. Otology \& Neurotology: Official Publication of the American Otological Society, American Neurotology Society [and] European Academy of Otology and Neurotology, 24 (2), 216-221.

Ma, Y., Wise, A.K., Shepherd, R.K., and Richardson, R.T., 2019. New molecular therapies for the treatment of hearing loss. Pharmacology \& Therapeutics.

MacLaren, R.E., Pearson, R.A., MacNeil, A., Douglas, R.H., Salt, T.E., Akimoto, M., Swaroop, A., Sowden, J.C., and Ali, R.R., 2006. Retinal repair by transplantation of photoreceptor precursors. Nature, 444 (7116), 203-207.

Maerker, T., van Wijk, E., Overlack, N., Kersten, F.F.J., McGee, J., Goldmann, T., Sehn, E., Roepman, R., Walsh, E.J., Kremer, H., and Wolfrum, U., 2008. A novel Usher protein network at the periciliary reloading point between molecular transport machineries in vertebrate photoreceptor cells. Human Molecular Genetics, 17 (1), 71-86.

Mahmoudi, P., Veladi, H., and Pakdel, F.G., 2017. Optogenetics, Tools and Applications in Neurobiology. Journal of Medical Signals and Sensors, 7 (2), 71-79.

Manor, U., Disanza, A., Grati, M., Andrade, L., Lin, H., Di Fiore, P.P., Scita, G., and Kachar, B., 2011. Regulation of stereocilia length by myosin $\mathrm{XVa}$ and whirlin depends on the actin-regulatory protein Eps8. Current biology: CB, 21 (2), 167-172

Marc, R., Pfeiffer, R., and Jones, B., 2014. Retinal Prosthetics, Optogenetics, and Chemical Photoswitches. ACS Chemical Neuroscience, 5 (10), 895-901.

Maria Oonk, A.M., van Huet, R.A.C., Leijendeckers, J.M., Oostrik, J., Venselaar, H., van Wijk, E., Beynon, A., Kunst, H.P.M., Hoyng, C.B., Kremer, H., Schraders, M., and Pennings, R.J.E., 2015. Nonsyndromic hearing loss caused by USH1G mutations: widening the USH1G disease spectrum. Ear and Hearing, 36 (2), 205-211.

Martínez-Fernández de la Cámara, C., Hernández-Pinto, A.M., Olivares-González, L., Cuevas-Martín, C., SánchezAragó, M., Hervás, D., Salom, D., Cuezva, J.M., de la Rosa, E.J., Millán, J.M., and Rodrigo, R., 2015. Adalimumab Reduces Photoreceptor Cell Death in A Mouse Model of Retinal Degeneration. Scientific Reports, 5, 11764. 
Maruyama, T., Dougan, S.K., Truttmann, M.C., Bilate, A.M., Ingram, J.R., and Ploegh, H.L., 2015. Increasing the efficiency of precise genome editing with CRISPR-Cas9 by inhibition of nonhomologous end joining. Nature Biotechnology, 33 (5), 538-542.

Mathur, P. and Yang, J., 2015. Usher syndrome: Hearing loss, retinal degeneration and associated abnormalities. Biochimica Et Biophysica Acta, 1852 (3), 406-420.

Mathur, P.D. and Yang, J., 2019. Usher syndrome and nonsyndromic deafness: Functions of different whirlin isoforms in the cochlea, vestibular organs, and retina. Hearing Research, 375, 14-24.

Matsuda, T. and Cepko, C.L., 2004. Electroporation and RNA interference in the rodent retina in vivo and in vitro. Proceedings of the National Academy of Sciences of the United States of America, 101 (1), 16-22.

Mazina, O.M. and Mazin, A.V., 2004. Human Rad54 protein stimulates DNA strand exchange activity of hRad51 protein in the presence of $\mathrm{Ca} 2+$. The Journal of Biological Chemistry, 279 (50), 52042-52051.

Mburu, P., Mustapha, M., Varela, A., Weil, D., El-Amraoui, A., Holme, R.H., Rump, A., Hardisty, R.E., Blanchard, S., Coimbra, R.S., Perfettini, I., Parkinson, N., Mallon, A.-M., Glenister, P., Rogers, M.J., Paige, A.J., Moir, L., Clay, J., Rosenthal, A., Liu, X.Z., Blanco, G., Steel, K.P., Petit, C., and Brown, S.D.M., 2003. Defects in whirlin, a PDZ domain molecule involved in stereocilia elongation, cause deafness in the whirler mouse and families with DFNB31. Nature Genetics, 34 (4), 421-428.

McCulloch, D.L., Marmor, M.F., Brigell, M.G., Hamilton, R., Holder, G.E., Tzekov, R., and Bach, M., 2015. ISCEV Standard for full-field clinical electroretinography (2015 update). Documenta Ophthalmologica. Advances in Ophthalmology, 130 (1), 1-12.

McGee, T.L., Seyedahmadi, B.J., Sweeney, M.O., Dryja, T.P., and Berson, E.L., 2010. Novel mutations in the long isoform of the USH2A gene in patients with Usher syndrome type II or non-syndromic retinitis pigmentosa. Journal of Medical Genetics, 47 (7), 499506.

McGrath, J., Roy, P., and Perrin, B.J., 2017. Stereocilia morphogenesis and maintenance through regulation of actin stability. Seminars in cell \& developmental biology, 65, 88-95.

McKusick, V.A., 2007. Mendelian Inheritance in Man and Its Online Version, OMIM. American Journal of Human Genetics, 80 (4), 588-604.

McMillan, D.R., Kayes-Wandover, K.M., Richardson, J.A., and White, P.C., 2002. Very large $G$ protein-coupled receptor-1, the largest known cell surface protein, is highly expressed in the developing central nervous system. The Journal of Biological Chemistry, 277 (1), 785-792.
Melendez, M.E., Fraefel, C., and Epstein, A.L., 2014. Herpes simplex virus type 1 (HSV-1)-derived amplicon vectors. Methods in Molecular Biology (Clifton, N.J.), 1144, 8198.

de Melo, J. and Blackshaw, S., 2018. In Vivo Electroporation of Developing Mouse Retina. Methods in molecular biology (Clifton, N.J.), 1715, 101-111.

Michalski, N., Michel, V., Bahloul, A., Lefèvre, G., Barral, J., Yagi, H., Chardenoux, S., Weil, D., Martin, P., Hardelin, J.P., Sato, M., and Petit, C., 2007. Molecular characterization of the ankle-link complex in cochlear hair cells and its role in the hair bundle functioning. The Journal of Neuroscience: The Official Journal of the Society for Neuroscience, 27 (24), 6478-6488.

Michel, V., Booth, K.T., Patni, P., Cortese, M., Azaiez, H., Bahloul, A., Kahrizi, K., Labbé, M., Emptoz, A., Lelli, A., Dégardin, J., Dupont, T., Aghaie, A., Oficjalska-Pham, D., Picaud, S., Najmabadi, H., Smith, R.J., Bowl, M.R., Brown, S.D., Avan, P., Petit, C., and El-Amraoui, A., 2017. CIB2, defective in isolated deafness, is key for auditory hair cell mechanotransduction and survival. EMBO Molecular Medicine, 9 (12), 1711-1731.

Millán, J.M., Aller, E., Jaijo, T., Blanco-Kelly, F., GimenezPardo, A., and Ayuso, C., 2011. An Update on the Genetics of Usher Syndrome. Journal of Ophthalmology, 2011.

Miller, J.C., Holmes, M.C., Wang, J., Guschin, D.Y., Lee, Y.-L., Rupniewski, I., Beausejour, C.M., Waite, A.J., Wang, N.S., Kim, K.A., Gregory, P.D., Pabo, C.O., and Rebar, E.J., 2007. An improved zinc-finger nuclease architecture for highly specific genome editing. Nature Biotechnology, 25 (7), 778-785.

Mishra, G.P., Bagui, M., Tamboli, V., and Mitra, A.K., 2011. Recent applications of liposomes in ophthalmic drug delivery. Journal of Drug Delivery, 2011, 863734.

Mittal, R., Nguyen, D., Patel, A.P., Debs, L.H., Mittal, J., Yan, D., Eshraghi, A.A., Van De Water, T.R., and Liu, X.Z., 2017. Recent Advancements in the Regeneration of Auditory Hair Cells and Hearing Restoration. Frontiers in Molecular Neuroscience, 10.

Möller, C.G., Kimberling, W.J., Davenport, S.L., Priluck, I., White, V., Biscone-Halterman, K., Odkvist, L.M., Brookhouser, P.E., Lund, G., and Grissom, T.J., 1989. Usher syndrome: an otoneurologic study. The Laryngoscope, 99 (1), 73-79.

Mortensen, R., 2007. Overview of gene targeting by homologous recombination. Current Protocols in Neuroscience, Chapter 4, Unit 4.29.

Moshourab, R., Bégay, V., Wetzel, C., Walcher, J., Middleton, S., Gross, M., and Lewin, G.R., 2017. Congenital deafness is associated with specific somatosensory deficits in adolescents. Scientific Reports, 7. 
Mout, R., Ray, M., Tonga, G.Y., Lee, Y.-W., Tay, T., Sasaki, K., and Rotello, V.M., 2017. Efficient Gene Editing through Direct Cytosolic Delivery of CRISPR/Cas9Ribonucleoprotein. ACS nano, 11 (3), 2452-2458.

Mustapha, M., Chouery, E., Torchard-Pagnez, D., Nouaille, S., Khrais, A., Sayegh, F.N., Mégarbané, A., Loiselet, J., Lathrop, M., Petit, C., and Weil, D., 2002. A novel locus for Usher syndrome type I, USH1G, maps to chromosome 17q24-25. Human Genetics, 110 (4), 348350.

Nakanishi, H., Ohtsubo, M., Iwasaki, S., Hotta, Y., Mizuta, K., Mineta, H., and Minoshima, S., 2009. Identification of 11 novel mutations in USH2A among Japanese patients with Usher syndrome type 2. Clinical Genetics, 76 (4), 383-391.

Naz, S., Alasti, F., Mowjoodi, A., Riazuddin, S., Sanati, M.H., Friedman, T.B., Griffith, A.J., Wilcox, E.R., and Riazuddin, S., 2003. Distinctive audiometric profile associated with DFNB21 alleles of TECTA. Journal of Medical Genetics, 40 (5), 360-363.

Nelson, C.E., Hakim, C.H., Ousterout, D.G., Thakore, P.I., Moreb, E.A., Castellanos Rivera, R.M., Madhavan, S., Pan, X., Ran, F.A., Yan, W.X., Asokan, A., Zhang, F., Duan, D., and Gersbach, C.A., 2016. In vivo genome editing improves muscle function in a mouse model of Duchenne muscular dystrophy. Science (New York, N.Y.), 351 (6271), 403-407.

Ness, S.L., Ben-Yosef, T., Bar-Lev, A., Madeo, A.C., Brewer, C.C., Avraham, K.B., Kornreich, R., Desnick, R.J., Willner, J.P., Friedman, T.B., and Griffith, A.J., 2003. Genetic homogeneity and phenotypic variability among Ashkenazi Jews with Usher syndrome type III. Journal of Medical Genetics, 40 (10), 767-772.

Neuhaus, C., Eisenberger, T., Decker, C., Nagl, S., Blank, C., Pfister, M., Kennerknecht, I., Müller-Hofstede, C., Charbel Issa, P., Heller, R., Beck, B., Rüther, K., Mitter, D., Rohrschneider, K., Steinhauer, U., Korbmacher, H.M., Huhle, D., Elsayed, S.M., Taha, H.M., Baig, S.M., Stöhr, H., Preising, M., Markus, S., Moeller, F., Lorenz, B., NagelWolfrum, K., Khan, A.O., and Bolz, H.J., 2017. Nextgeneration sequencing reveals the mutational landscape of clinically diagnosed Usher syndrome: copy number variations, phenocopies, a predominant target for translational read-through, andPEX26mutated in Heimler syndrome. Molecular Genetics \& Genomic Medicine, 5 (5), 531-552.

Neveling, K., Collin, R.W.J., Gilissen, C., van Huet, R.A.C., Visser, L., Kwint, M.P., Gijsen, S.J., Zonneveld, M.N., Wieskamp, N., de Ligt, J., Siemiatkowska, A.M., Hoefsloot, L.H., Buckley, M.F., Kellner, U., Branham, K.E., den Hollander, A.I., Hoischen, A., Hoyng, C., Klevering, B.J., van den Born, L.I., Veltman, J.A., Cremers, F.P.M., and Scheffer, H., 2012. Next-generation genetic testing for retinitis pigmentosa. Human Mutation, 33 (6), 963-972.
Ng, T.K., Tang, W., Cao, Y., Chen, S., Zheng, Y., Xiao, X., and Chen, $H_{\text {., }}$ 2019. Whole exome sequencing identifies novel USH2A mutations and confirms Usher syndrome 2 diagnosis in Chinese retinitis pigmentosa patients. Scientific Reports, 9 (1), 5628.

Nickerson, J.M., Getz, S.E., Sellers, J.T., Chrenek, M.A., Goodman, P., Bernal, C.J., and Boatright, J.H., 2014. DNA delivery in adult mouse eyes: An update with corneal endothelium outcomes. Methods in molecular biology (Clifton, N.J.), 1121, 165-177.

Nie, J. and Hashino, E., 2017. Organoid technologies meet genome engineering. EMBO Reports, 18 (3), 367-376.

Niroula, A. and Vihinen, M., 2016. Variation Interpretation Predictors: Principles, Types, Performance, and Choice. Human Mutation, 37 (6), 579-597.

Ogun, O. and Zallocchi, M., 2014. Clarin-1 acts as a modulator of mechanotransduction activity and presynaptic ribbon assembly. The Journal of Cell Biology, 207 (3), 375-391.

Oishi, M., Oishi, A., Gotoh, N., Ogino, K., Higasa, K., lida, K., Makiyama, Y., Morooka, S., Matsuda, F., and Yoshimura, N., 2014. Comprehensive molecular diagnosis of a large cohort of Japanese retinitis pigmentosa and Usher syndrome patients by next-generation sequencing. Investigative Ophthalmology \& Visual Science, 55 (11), 7369-7375.

Okano, S., Makita, Y., Katada, A., Harabuchi, Y., Kohmoto, T., Naruto, T., Masuda, K., and Imoto, I., 2019. Novel compound heterozygous $\mathrm{CDH} 23$ variants in a patient with Usher syndrome type I. Human Genome Variation, 6,8 .

Olivares-González, L., Martínez-Fernández de la Cámara, C., Hervás, D., Millán, J.M., and Rodrigo, R., 2018. HIF-1 $\alpha$ stabilization reduces retinal degeneration in a mouse model of retinitis pigmentosa. FASEB journal: official publication of the Federation of American Societies for Experimental Biology, 32 (5), 2438-2451.

Oshima, A., Jaijo, T., Aller, E., Millan, J.M., Carney, C., Usami, S., Moller, C., and Kimberling, W.J., 2008. Mutation profile of the $\mathrm{CDH} 23$ gene in 56 probands with Usher syndrome type I. Human Mutation, 29 (6), E37-46.

Ou, Z., Niu, X., He, W., Chen, Y., Song, B., Xian, Y., Fan, D., Tang, D., and Sun, $X_{\text {., }}$ 2016. The Combination of CRISPR/Cas9 and iPSC Technologies in the Gene Therapy of Human $\beta$-thalassemia in Mice. Scientific Reports, 6, 32463.

Ouyang, X.M., Xia, X.J., Verpy, E., Du, L.L., Pandya, A., Petit, C., Balkany, T., Nance, W.E., and Liu, X.Z., 2002. Mutations in the alternatively spliced exons of USH1C cause nonsyndromic recessive deafness. Human Genetics, 111 (1), 26-30. 
Ouyang, X.M., Yan, D., Du, L.L., Hejtmancik, J.F., Jacobson, S.G., Nance, W.E., Li, A.R., Angeli, S., Kaiser, M., Newton, V., Brown, S.D.M., Balkany, T., and Liu, X.Z., 2005. Characterization of Usher syndrome type I gene mutations in an Usher syndrome patient population. Human Genetics, 116 (4), 292-299.

van Overbeek, M., Capurso, D., Carter, M.M., Thompson, M.S., Frias, E., Russ, C., Reece-Hoyes, J.S., Nye, C., Gradia, S., Vidal, B., Zheng, J., Hoffman, G.R., Fuller, C.K., and May, A.P., 2016. DNA Repair Profiling Reveals Nonrandom Outcomes at Cas9-Mediated Breaks. Molecular Cell, 63 (4), 633-646.

Overlack, N., Kilic, D., Bauss, K., Märker, T., Kremer, H., van Wijk, E., and Wolfrum, U., 2011. Direct interaction of the Usher syndrome $1 \mathrm{G}$ protein SANS and myomegalin in the retina. Biochimica Et Biophysica Acta, 1813 (10), 1883-1892.

Pakarinen, L., Karjalainen, S., Simola, K.O., Laippala, P., and Kaitalo, H., 1995. Usher' s syndrome type 3 in Finland. The Laryngoscope, 105 (6), 613-617.

Pan, B., Askew, C., Galvin, A., Heman-Ackah, S., Asai, Y., Indzhykulian, A.A., Jodelka, F.M., Hastings, M.L., Lentz, J.J., Vandenberghe, L.H., Holt, J.R., and Géléoc, G.G.S., 2017. Gene Therapy Restores Auditory and Vestibular Function in a Mouse Model of Usher Syndrome Type 1c. Nature biotechnology, 35 (3), 264-272.

Pan, L., Yan, J., Wu, L., and Zhang, M., 2009. Assembling stable hair cell tip link complex via multidentate interactions between harmonin and cadherin 23. Proceedings of the National Academy of Sciences of the United States of America, 106 (14), 5575-5580.

Parks, R.J., Chen, L., Anton, M., Sankar, U., Rudnicki, M.A., and Graham, F.L., 1996. A helper-dependent adenovirus vector system: Removal of helper virus by Cre-mediated excision of the viral packaging signal. Proceedings of the National Academy of Sciences of the United States of America, 93 (24), 13565-13570.

Paulsen, B.S., Mandal, P.K., Frock, R.L., Boyraz, B., Yadav, R., Upadhyayula, S., Gutierrez-Martinez, P., Ebina, W., Fasth, A., Kirchhausen, T., Talkowski, M.E., Agarwal, S., Alt, F.W., and Rossi, D.J., 2017. Ectopic expression of RAD52 and dn53BP1 improves homology-directed repair during CRISPR-Cas9 genome editing. Nature Biomedical Engineering, 1 (11), 878-888.

Pearson, R.A., Barber, A.C., Rizzi, M., Hippert, C., Xue, T., West, E.L., Duran, Y., Smith, A.J., Chuang, J.Z., Azam, S.A., Luhmann, U.F.O., Benucci, A., Sung, C.H., Bainbridge, J.W., Carandini, M., Yau, K.-W., Sowden, J.C., and Ali, R.R., 2012. Restoration of vision after transplantation of photoreceptors. Nature, 485 (7396), 99-103.
Pearson, R.A., Gonzalez-Cordero, A., West, E.L., Ribeiro, J.R., Aghaizu, N., Goh, D., Sampson, R.D., Georgiadis, A., Waldron, P.V., Duran, Y., Naeem, A., Kloc, M., Cristante, E., Kruczek, K., Warre-Cornish, K., Sowden, J.C., Smith, A.J., and Ali, R.R., 2016. Donor and host photoreceptors engage in material transfer following transplantation of post-mitotic photoreceptor precursors. Nature Communications, 7, 13029.

Pedersen, A.G. and Nielsen, H., 1997. Neural network prediction of translation initiation sites in eukaryotes: perspectives for EST and genome analysis. Proceedings. International Conference on Intelligent Systems for Molecular Biology, 5, 226-233.

Peng, B.-G., Ahmad, S., Chen, S., Chen, P., Price, M.P., and Lin, X., 2004. Acid-sensing ion channel 2 contributes a major component to acid-evoked excitatory responses in spiral ganglion neurons and plays a role in noise susceptibility of mice. The Journal of Neuroscience: The Official Journal of the Society for Neuroscience, 24 (45), 10167-10175.

Peng, Y., Tang, L., and Zhou, Y., 2017. Subretinal Injection: A Review on the Novel Route of Therapeutic Delivery for Vitreoretinal Diseases. Ophthalmic Research, 58 (4), 217-226.

Pennings, R.J.E., Damen, G.W.J.A., Snik, A.F.M., Hoefsloot, L., Cremers, C.W.R.J., and Mylanus, E.A.M., 2006. Audiologic performance and benefit of cochlear implantation in Usher syndrome type I. The Laryngoscope, 116 (5), 717-722.

Pennings, R.J.E., Huygen, P.L.M., Orten, D.J., Wagenaar, M., van Aarem, A., Kremer, H., Kimberling, W.J., Cremers, C.W.R.J., and Deutman, A.F., 2004. Evaluation of visual impairment in Usher syndrome $1 \mathrm{~b}$ and Usher syndrome 2a. Acta Ophthalmologica Scandinavica, 82 (2), 131139.

Petit, C., 2001. Usher syndrome: from genetics to pathogenesis. Annual Review of Genomics and Human Genetics, 2, 271-297.

Philippakis, A.A., Azzariti, D.R., Beltran, S., Brookes, A.J., Brownstein, C.A., Brudno, M., Brunner, H.G., Buske, O.J., Carey, K., Doll, C., Dumitriu, S., Dyke, S.O.M., Dunnen, J.T. den, Firth, H.V., Gibbs, R.A., Girdea, M., Gonzalez, M., Haendel, M.A., Hamosh, A., Holm, I.A., Huang, L., Hurles, M.E., Hutton, B., Krier, J.B., Misyura, A., Mungall, C.J., Paschall, J., Paten, B., Robinson, P.N., Schiettecatte, F., Sobreira, N.L., Swaminathan, G.J., Taschner, P.E., Terry, S.F., Washington, N.L., Züchner, S., Boycott, K.M., and Rehm, H.L., 2015. The Matchmaker Exchange: A Platform for Rare Disease Gene Discovery [online]. Human Mutation. Available from: https://onlinelibrary.wiley.com/doi/abs/10.1002/humu. 22858 [Accessed 17 Jul 2019]. 
Pickett, S.J., Grady, J.P., Ng, Y.S., Gorman, G.S., Schaefer, A.M., Wilson, I.J., Cordell, H.J., Turnbull, D.M., Taylor, R.W., and McFarland, R., 2018. Phenotypic heterogeneity in m.3243A>G mitochondrial disease: The role of nuclear factors. Annals of Clinical and Translational Neurology, 5 (3), 333-345.

Pierrottet, C.O., Zuntini, M., Digiuni, M., Bazzanella, I., Ferri, P., Paderni, R., Rossetti, L.M., Cecchin, S., Orzalesi, N., and Bertelli, M., 2014. Syndromic and non-syndromic forms of retinitis pigmentosa: a comprehensive Italian clinical and molecular study reveals new mutations. Genetics and molecular research: GMR, 13 (4), 8815-8833.

Pinder, J., Salsman, J., and Dellaire, G., 2015. Nuclear domain 'knock-in' screen for the evaluation and identification of small molecule enhancers of CRISPRbased genome editing. Nucleic Acids Research, 43 (19), 9379-9392.

Pinello, L., Canver, M.C., Hoban, M.D., Orkin, S.H., Kohn, D.B., Bauer, D.E., and Yuan, G.-C., 2016. Analyzing CRISPR genome editing experiments with CRISPResso. Nature biotechnology, 34 (7), 695-697.

Pollard, K.S., Hubisz, M.J., Rosenbloom, K.R., and Siepel, A., 2010. Detection of nonneutral substitution rates on mammalian phylogenies. Genome Research, 20 (1), 110-121.

Powers, R.E., Gaudet, R., and Sotomayor, M., 2017. A Partial Calcium-Free Linker Confers Flexibility to Inner-Ear Protocadherin-15. Structure (London, England: 1993), 25 (3), 482-495.

Puffenberger, E.G., Jinks, R.N., Sougnez, C., Cibulskis, K., Willert, R.A., Achilly, N.P., Cassidy, R.P., Fiorentini, C.J., Heiken, K.F., Lawrence, J.J., Mahoney, M.H., Miller, C.J., Nair, D.T., Politi, K.A., Worcester, K.N., Setton, R.A., Dipiazza, R., Sherman, E.A., Eastman, J.T., Francklyn, C., Robey-Bond, S., Rider, N.L., Gabriel, S., Morton, D.H., and Strauss, K.A., 2012. Genetic mapping and exome sequencing identify variants associated with five novel diseases. PloS One, 7 (1), e28936.

Qi, L.S., Larson, M.H., Gilbert, L.A., Doudna, J.A., Weissman, J.S., Arkin, A.P., and Lim, W.A., 2013. Repurposing CRISPR as an RNA-guided platform for sequencespecific control of gene expression. Cell, 152 (5), 11731183.

Qu, L.-H., Jin, X., Xu, H.-W., Li, S.-Y., and Yin, Z.-Q., 2015. Detecting novel genetic mutations in Chinese Usher syndrome families using next-generation sequencing technology. Molecular genetics and genomics: $M G G$, 290 (1), 353-363.

Quail, M.A., Smith, M., Coupland, P., Otto, T.D., Harris, S.R., Connor, T.R., Bertoni, A., Swerdlow, H.P., and Gu, Y., 2012. A tale of three next generation sequencing platforms: comparison of Ion Torrent, Pacific Biosciences and Illumina MiSeq sequencers. BMC genomics, 13, 341
Raas-Rothschild, A., Wanders, R.J.A., Mooijer, P.A.W., Gootjes, J., Waterham, H.R., Gutman, A., Suzuki, Y., Shimozawa, N., Kondo, N., Eshel, G., Espeel, M., Roels, F., and Korman, S.H., 2002. A PEX6-defective peroxisomal biogenesis disorder with severe phenotype in an infant, versus mild phenotype resembling Usher syndrome in the affected parents. American Journal of Human Genetics, 70 (4), 1062-1068.

Rachitskaya, A.V. and Yuan, A., 2016. Argus II retinal prosthesis system: An update. Ophthalmic Genetics, 37 (3), 260-266.

Radecke, S., Radecke, F., Cathomen, T., and Schwarz, K., 2010. Zinc-finger Nuclease-induced Gene Repair With Oligodeoxynucleotides: Wanted and Unwanted Target Locus Modifications. Molecular Therapy, 18 (4), 743753.

Ramzan, K., Al-Owain, M., Huma, R., Al-Hazzaa, S.A.F., AlAgeel, S., Imtiaz, F., and Al-Sayed, M., 2018. Utility of whole exome sequencing in the diagnosis of Usher syndrome: Report of novel compound heterozygous MYO7A mutations. International Journal of Pediatric Otorhinolaryngology, 108, 17-21.

Ran, F.A., Cong, L., Yan, W.X., Scott, D.A., Gootenberg, J.S., Kriz, A.J., Zetsche, B., Shalem, O., Wu, X., Makarova, K.S., Koonin, E.V., Sharp, P.A., and Zhang, F., 2015. In vivo genome editing using Staphylococcus aureus Cas9. Nature, 520 (7546), 186-191.

Ran, F.A., Hsu, P.D., Lin, C.-Y., Gootenberg, J.S., Konermann, S., Trevino, A., Scott, D.A., Inoue, A., Matoba, S., Zhang, Y., and Zhang, F., 2013a. Double nicking by RNA-guided CRISPR Cas9 for enhanced genome editing specificity. Cell, 154 (6), 1380-1389.

Ran, F.A., Hsu, P.D., Wright, J., Agarwala, V., Scott, D.A., and Zhang, F., 2013b. Genome engineering using the CRISPR-Cas9 system. Nature Protocols, 8 (11), 22812308.

Raymond, M., Walker, E., Dave, I., and Dedhia, K., 2019. Genetic testing for congenital non-syndromic sensorineural hearing loss. International Journal of Pediatric Otorhinolaryngology, 124, 68-75.

Reddy, R., Fahiminiya, S., El Zir, E., Mansour, A., Megarbane, A., Majewski, J., and Slim, R., 2014. Molecular Genetics of the Usher Syndrome in Lebanon: Identification of 11 Novel Protein Truncating Mutations by Whole Exome Sequencing. PLOS ONE, 9 (9).

Rees, H.A. and Liu, D.R., 2018. Base editing: precision chemistry on the genome and transcriptome of living cells. Nature reviews. Genetics, 19 (12), 770-788.

Rees, H.A., Yeh, W.-H., and Liu, D.R., 2019. Development of hRad51-Cas9 nickase fusions that mediate HDR without double-stranded breaks. Nature Communications, 10. 
Reese, M.G., Eeckman, F.H., Kulp, D., and Haussler, D., 1997. Improved splice site detection in Genie. Journal of Computational Biology: A Journal of Computational Molecular Cell Biology, 4 (3), 311-323.

Reiners, J., Märker, T., Jürgens, K., Reidel, B., and Wolfrum, U., 2005a. Photoreceptor expression of the Usher syndrome type 1 protein protocadherin 15 (USH1F) and its interaction with the scaffold protein harmonin (USH1C). Molecular Vision, 11, 347-355.

Reiners, J., Nagel-Wolfrum, K., Jürgens, K., Märker, T., and Wolfrum, U., 2006. Molecular basis of human Usher syndrome: deciphering the meshes of the Usher protein network provides insights into the pathomechanisms of the Usher disease. Experimental Eye Research, 83 (1), 97-119.

Reiners, J., van Wijk, E., Märker, T., Zimmermann, U., Jürgens, K., te Brinke, $H_{\text {., }}$ Overlack, N., Roepman, R., Knipper, M., Kremer, H., and Wolfrum, U., 2005b. Scaffold protein harmonin (USH1C) provides molecular links between Usher syndrome type 1 and type 2 . Human Molecular Genetics, 14 (24), 3933-3943.

Renaud, J.-B., Boix, C., Charpentier, M., De Cian, A., Cochennec, J., Duvernois-Berthet, E., Perrouault, L., Tesson, L., Edouard, J., Thinard, R., Cherifi, Y., Menoret, S., Fontanière, S., de Crozé, N., Fraichard, A., Sohm, F., Anegon, I., Concordet, J.-P., and Giovannangeli, C., 2016. Improved Genome Editing Efficiency and Flexibility Using Modified Oligonucleotides with TALEN and CRISPR-Cas9 Nucleases. Cell Reports, 14 (9), 2263-2272.

Reyon, D., Tsai, S.Q., Khayter, C., Foden, J.A., Sander, J.D., and Joung, J.K., 2012. FLASH assembly of TALENs for high-throughput genome editing. Nature Biotechnology, 30 (5), 460-465.

Riazuddin, S., Belyantseva, I.A., Giese, A., Lee, K., Indzhykulian, A.A., Nandamuri, S.P., Yousaf, R., Sinha, G.P., Lee, S., Terrell, D., Hegde, R.S., Ali, R.A., Anwar, S., Andrade-Elizondo, P.B., Sirmaci, A., Parise, L.V., Basit, S., Wali, A., Ayub, M., Ansar, M., Ahmad, W., Khan, S.N., Akram, J., Tekin, M., Riazuddin, S., Cook, T., Buschbeck, E.K., Frolenkov, G.I., Leal, S.M., Friedman, T.B., and Ahmed, Z.M., 2012. Mutations in CIB2, a calcium and integrin binding protein, cause Usher syndrome type $1 J$ and nonsyndromic deafness DFNB48. Nature genetics, 44 (11), 1265-1271.

Riazuddin, S., Nazli, S., Ahmed, Z.M., Yang, Y., Zulfiqar, F., Shaikh, R.S., Zafar, A.U., Khan, S.N., Sabar, F., Javid, F.T., Wilcox, E.R., Tsilou, E., Boger, E.T., Sellers, J.R., Belyantseva, I.A., Riazuddin, S., and Friedman, T.B., 2008. Mutation spectrum of MYO7A and evaluation of a novel nonsyndromic deafness DFNB2 allele with residual function. Human Mutation, 29 (4), 502-511.

Ribeiro, J.C., Oliveiros, B., Pereira, P., António, N., Hummel, T., Paiva, A., and Silva, E.D., 2016. Accelerated agerelated olfactory decline among type 1 Usher patients. Scientific Reports, 6, 28309.
Richard, E.M., Santos-Cortez, R.L.P., Faridi, R., Rehman, A.U., Lee, K., Shahzad, M., Acharya, A., Khan, A.A., Imtiaz, A., Chakchouk, I., Takla, C., Abbe, I., Rafeeq, M., Liaqat, K., Chaudhry, T., Bamshad, M.J., Nickerson, D.A., University of Washington Center for Mendelian Genomics, Schrauwen, I., Khan, S.N., Morell, R.J., Zafar, S., Ansar, M., Ahmed, Z.M., Ahmad, W., Riazuddin, S., Friedman, T.B., Leal, S.M., and Riazuddin, S., 2019. Global genetic insight contributed by consanguineous Pakistani families segregating hearing loss. Human Mutation, 40 (1), 5372.

Richards, S., Aziz, N., Bale, S., Bick, D., Das, S., GastierFoster, J., Grody, W.W., Hegde, M., Lyon, E., Spector, E., Voelkerding, K., Rehm, H.L., and ACMG Laboratory Quality Assurance Committee, 2015. Standards and guidelines for the interpretation of sequence variants: a joint consensus recommendation of the American College of Medical Genetics and Genomics and the Association for Molecular Pathology. Genetics in Medicine: Official Journal of the American College of Medical Genetics, 17 (5), 405-424.

Richardson, C.D., Kazane, K.R., Feng, S.J., Zelin, E., Bray, N.L., Schäfer, A.J., Floor, S.N., and Corn, J.E., 2018. CRISPR-Cas9 genome editing in human cells occurs via the Fanconi anemia pathway. Nature Genetics, 50 (8), 1132-1139.

Richardson, C.D., Ray, G.J., DeWitt, M.A., Curie, G.L., and Corn, J.E., 2016. Enhancing homology-directed genome editing by catalytically active and inactive CRISPR-Cas9 using asymmetric donor DNA. Nature Biotechnology, 34 (3), 339-344.

Richardson, G.P., de Monvel, J.B., and Petit, C., 2011. How the Genetics of Deafness Illuminates Auditory Physiology. Annual Review of Physiology, 73 (1), 311334.

Rinaldi, C. and Wood, M.J.A., 2018. Antisense oligonucleotides: the next frontier for treatment of neurological disorders. Nature Reviews. Neurology, 14 (1), 9-21.

Rivolta, C., Sweklo, E.A., Berson, E.L., and Dryja, T.P., 2000. Missense mutation in the USH2A gene: association with recessive retinitis pigmentosa without hearing loss. American Journal of Human Genetics, 66 (6), 19751978.

Robert, F., Barbeau, M., Éthier, S., Dostie, J., and Pelletier, J., 2015. Pharmacological inhibition of DNA-PK stimulates Cas9-mediated genome editing. Genome Medicine, 7 (1).

Roux, A.-F., Faugère, V., Le Guédard, S., Pallares-Ruiz, N., Vielle, A., Chambert, S., Marlin, S., Hamel, C., Gilbert, B., Malcolm, S., Claustres, M., and French Usher Syndrome Collaboration, 2006. Survey of the frequency of USH1 gene mutations in a cohort of Usher patients shows the importance of cadherin 23 and protocadherin 15 genes and establishes a detection rate of above $90 \%$. Journal of Medical Genetics, 43 (9), 763-768. 
Roux, A.-F., Faugère, V., Vaché, C., Baux, D., Besnard, T., Léonard, S., Blanchet, C., Hamel, C., Mondain, M., Gilbert-Dussardier, B., Edery, P., Lacombe, D., Bonneau, D., Holder-Espinasse, M., Ambrosetti, U., Journel, H., David, A., Lina-Granade, G., Malcolm, S., and Claustres, M., 2011. Four-year follow-up of diagnostic service in USH1 patients. Investigative Ophthalmology \& Visual Science, 52 (7), 4063-4071.

Sahel, J.-A., Marazova, K., and Audo, I., 2015. Clinical Characteristics and Current Therapies for Inherited Retinal Degenerations. Cold Spring Harbor Perspectives in Medicine, 5 (2).

Sahly, I., Dufour, E., Schietroma, C., Michel, V., Bahloul, A., Perfettini, I., Pepermans, E., Estivalet, A., Carette, D., Aghaie, A., Ebermann, I., Lelli, A., Iribarne, M., Hardelin, J.-P., Weil, D., Sahel, J.-A., El-Amraoui, A., and Petit, C., 2012. Localization of Usher 1 proteins to the photoreceptor calyceal processes, which are absent from mice. The Journal of Cell Biology, 199 (2), 381-399.

Sahly, I., El-Amraoui, A., Abitbol, M., Petit, C., and Dufier, J.L., 1997. Expression of myosin VIIA during mouse embryogenesis. Anatomy and Embryology, 196 (2), 159-170.

Sakai, H., Lingueglia, E., Champigny, G., Mattei, M.G., and Lazdunski, M., 1999. Cloning and functional expression of a novel degenerin-like $\mathrm{Na}+$ channel gene in mammals. The Journal of Physiology, 519 Pt 2, 323-333.

Salamov, A.A., Nishikawa, T., and Swindells, M.B., 1998. Assessing protein coding region integrity in CDNA sequencing projects. Bioinformatics (Oxford, England), 14 (5), 384-390

Sander, J.D. and Joung, J.K., 2014. CRISPR-Cas systems for editing, regulating and targeting genomes. Nature Biotechnology, 32 (4), 347-355.

Sankila, E.M., Pakarinen, L., Kääriäinen, H., Aittomäki, K., Karjalainen, S., Sistonen, P., and de la Chapelle, A., 1995. Assignment of an Usher syndrome type III (USH3) gene to chromosome 3q. Human Molecular Genetics, 4 (1), 93-98.

Santana, E.E., Fuster-García, C., Aller, E., Jaijo, T., GarcíaBohórquez, B., García-García, G., Millán, J.M., and Lantigua, A., 2019. Genetic Screening of the Usher Syndrome in Cuba. Frontiers in Genetics, 10.

Santos-Ferreira, T., Postel, K., Stutzki, H., Kurth, T., Zeck, G., and Ader, M., 2015. Daylight vision repair by cell transplantation. Stem Cells (Dayton, Ohio), 33 (1), 79-90.

Schaefer, L., Sakai, H., Mattei, M., Lazdunski, M., and Lingueglia, E., 2000. Molecular cloning, functional expression and chromosomal localization of an amiloride-sensitive $\mathrm{Na}(+)$ channel from human small intestine. FEBS letters, 471 (2-3), 205-210.
Schietroma, C., Parain, K., Estivalet, A., Aghaie, A., Boutet de Monvel, J., Picaud, S., Sahel, J.-A., Perron, M., ElAmraoui, A., and Petit, C., 2017. Usher syndrome type 1associated cadherins shape the photoreceptor outer segment. The Journal of Cell Biology, 216 (6), 18491864.

Schimel, A.M., Abraham, L., Cox, D., Sene, A., Kraus, C., Dace, D.S., Ercal, N., and Apte, R.S., 2011. NAcetylcysteine Amide (NACA) Prevents Retinal Degeneration by Up-Regulating Reduced Glutathione Production and Reversing Lipid Peroxidation. The American Journal of Pathology, 178 (5), 2032-2043.

Schultz, J.M., Bhatti, R., Madeo, A.C., Turriff, A., Muskett, J.A., Zalewski, C.K., King, K.A., Ahmed, Z.M., Riazuddin, S., Ahmad, N., Hussain, Z., Qasim, M., Kahn, S.N., Meltzer, M.R., Liu, X.Z., Munisamy, M., Ghosh, M., Rehm, H.L., Tsilou, E.T., Griffith, A.J., Zein, W.M., Brewer, C.C., Riazuddin, S., and Friedman, T.B., 2011. Allelic hierarchy of $\mathrm{CDH} 23$ mutations causing non-syndromic deafness DFNB12 or Usher syndrome USH1D in compound heterozygotes. Journal of Medical Genetics, 48 (11), 767-775.

Seeliger, M., Pfister, M., Gendo, K., Paasch, S., ApfelstedtSylla, E., Plinkert, P., Zenner, H.P., and Zrenner, E., 1999. Comparative study of visual, auditory, and olfactory function in Usher syndrome. Graefe's Archive for Clinical and Experimental Ophthalmology = Albrecht Von Graefes Archiv Fur Klinische Und Experimentelle Ophthalmologie, 237 (4), 301-307.

Senften, M., Schwander, M., Kazmierczak, P., Lillo, C., Shin, J.-B., Hasson, T., Géléoc, G.S.G., Gillespie, P.G., Williams, D., Holt, J.R., and Müller, U., 2006. Physical and functional interaction between protocadherin 15 and myosin VIla in mechanosensory hair cells. The Journal of Neuroscience: The Official Journal of the Society for Neuroscience, 26 (7), 2060-2071.

Sengillo, J.D., Justus, S., Tsai, Y.-T., Cabral, T., and Tsang, S.H., 2016. Gene and cell-based therapies for inherited retinal disorders: An update. American Journal of Medical Genetics. Part C, Seminars in Medical Genetics, 172 (4), 349-366.

Shen, M.W., Arbab, M., Hsu, J.Y., Worstell, D., Culbertson, S.J., Krabbe, O., Cassa, C.A., Liu, D.R., Gifford, D.K., and Sherwood, R.I., 2018. Predictable and precise templatefree CRISPR editing of pathogenic variants. Nature, 563 (7733), 646-651.

Sheng, M. and Sala, C., 2001. PDZ domains and the organization of supramolecular complexes. Annual Review of Neuroscience, 24, 1-29.

Sheridan, C., 2018. Go-ahead for first in-body CRISPR medicine testing. Nature Biotechnology. 
Shu, H.-R., Bi, H., Pan, Y.-C., Xu, H.-Y., Song, J.-X., and Hu, J., 2015. Targeted exome sequencing reveals novel USH2A mutations in Chinese patients with simplex Usher syndrome. BMC Medical Genetics, 16.

Siemens, J., Kazmierczak, P., Reynolds, A., Sticker, M., Littlewood-Evans, A., and Müller, U., 2002. The Usher syndrome proteins cadherin 23 and harmonin form a complex by means of PDZ-domain interactions. Proceedings of the National Academy of Sciences of the United States of America, 99 (23), 14946-14951.

Simpson, D.A., Clark, G.R., Alexander, S., Silvestri, G., and Willoughby, C.E., 2011. Molecular diagnosis for heterogeneous genetic diseases with targeted highthroughput DNA sequencing applied to retinitis pigmentosa. Journal of Medical Genetics, 48 (3), 145151.

Simunovic, M.P., Shen, W., Lin, J.Y., Protti, D.A., Lisowski, L., and Gillies, M.C., 2019. Optogenetic approaches to vision restoration. Experimental Eye Research, 178, 1526.

Singh, D., Wang, Y., Mallon, J., Yang, O., Fei, J., Poddar, A., Ceylan, D., Bailey, S., and Ha, T., 2018a. Mechanisms of improved specificity of engineered Cas9s revealed by single molecule FRET analysis. Nature structural \& molecular biology, 25 (4), 347-354.

Singh, M.S., Charbel Issa, P., Butler, R., Martin, C., Lipinski, D.M., Sekaran, S., Barnard, A.R., and MacLaren, R.E., 2013. Reversal of end-stage retinal degeneration and restoration of visual function by photoreceptor transplantation. Proceedings of the National Academy of Sciences of the United States of America, 110 (3), 1101-1106.

Singh, R., Cuzzani, O., Binette, F., Sternberg, H., West, M.D., and Nasonkin, I.O., 2018b. Pluripotent Stem Cells for Retinal Tissue Engineering: Current Status and Future Prospects. Stem Cell Reviews, 14 (4), 463-483.

Slaymaker, I.M., Gao, L., Zetsche, B., Scott, D.A., Yan, W.X., and Zhang, F., 2016. Rationally engineered Cas9 nucleases with improved specificity. Science (New York, N.Y.), 351 (6268), 84-88.

Slijkerman, R.W., Vaché, C., Dona, M., García-García, G., Claustres, M., Hetterschijt, L., Peters, T.A., Hartel, B.P., Pennings, R.J., Millan, J.M., Aller, E., Garanto, A., Collin, R.W., Kremer, H., Roux, A.-F., and Van Wijk, E., 2016. Antisense Oligonucleotide-based Splice Correction for USH2A-associated Retinal Degeneration Caused by a Frequent Deep-intronic Mutation. Molecular Therapy. Nucleic Acids, 5 (10), e381.
Smith, K.R., Damiano, J., Franceschetti, S., Carpenter, S., Canafoglia, L., Morbin, M., Rossi, G., Pareyson, D., Mole, S.E., Staropoli, J.F., Sims, K.B., Lewis, J., Lin, W.-L., Dickson, D.W., Dahl, H.-H., Bahlo, M., and Berkovic, S.F., 2012. Strikingly Different Clinicopathological Phenotypes Determined by Progranulin-Mutation Dosage. American Journal of Human Genetics, 90 (6), 11021107.

Smith, R.J., Berlin, C.I., Hejtmancik, J.F., Keats, B.J., Kimberling, W.J., Lewis, R.A., Möller, C.G., Pelias, M.Z., and Tranebjaerg, L., 1994. Clinical diagnosis of the Usher syndromes. Usher Syndrome Consortium. American Journal of Medical Genetics, 50 (1), 32-38.

Smith, R.J., Lee, E.C., Kimberling, W.J., Daiger, S.P., Pelias, M.Z., Keats, B.J., Jay, M., Bird, A., Reardon, W., and Guest, M., 1992. Localization of two genes for Usher syndrome type I to chromosome 11. Genomics, 14 (4), 995-1002.

Song, F. and Stieger, K., 2017. Optimizing the DNA Donor Template for Homology-Directed Repair of DoubleStrand Breaks. Molecular Therapy. Nucleic Acids, 7, 5360.

Song, J., Yang, D., Xu, J., Zhu, T., Chen, Y.E., and Zhang, J., 2016. RS-1 enhances CRISPR/Cas9- and TALENmediated knock-in efficiency. Nature Communications, 7.

Song, L., Huang, W., Kang, J., Huang, Y., Ren, H., and Ding, K., 2017. Comparison of error correction algorithms for Ion Torrent PGM data: application to hepatitis B virus. Scientific Reports, 7.

Sorusch, N., Bauß, K., Plutniok, J., Samanta, A., Knapp, B., Nagel-Wolfrum, K., and Wolfrum, U., 2017. Characterization of the ternary Usher syndrome SANS/ush2a/whirlin protein complex. Human Molecular Genetics, 26 (6), 1157-1172.

Sorusch, N., Wunderlich, K., Bauss, K., Nagel-Wolfrum, K., and Wolfrum, U., 2014. Usher Syndrome Protein Network Functions in the Retina and their Relation to Other Retinal Ciliopathies. Retinal Degenerative Diseases, 527-533.

Sotomayor, M., Weihofen, W.A., Gaudet, R., and Corey, D.P., 2012. Structure of a force-conveying cadherin bond essential for inner-ear mechanotransduction. Nature, 492 (7427), 128-132.

Stein, C.A. and Castanotto, D., 2017. FDA-Approved Oligonucleotide Therapies in 2017. Molecular Therapy, 25 (5), 1069-1075.

Stenson, P.D., Ball, E.V., Mort, M., Phillips, A.D., Shiel, J.A., Thomas, N.S.T., Abeysinghe, S., Krawczak, M., and Cooper, D.N., 2003. Human Gene Mutation Database (HGMD): 2003 update. Human Mutation, 21 (6), 577581. 
Storici, F., Snipe, J.R., Chan, G.K., Gordenin, D.A., and Resnick, M.A., 2006. Conservative repair of a chromosomal double-strand break by single-strand DNA through two steps of annealing. Molecular and Cellular Biology, 26 (20), 7645-7657.

Sun, J.-P., Li, R., Ren, H.-Z., Xu, A.-T., Yu, X., and Xu, Z.-G., 2013. The very large $G$ protein coupled receptor (Vlgr1) in hair cells. Journal of molecular neuroscience: $M N, 50$ (1), 204-214.

Sun, T., Xu, K., Ren, Y., Xie, Y., Zhang, X., Tian, L., and Li, Y., 2018. Comprehensive Molecular Screening in Chinese Usher Syndrome Patients. Investigative Ophthalmology \& Visual Science, 59 (3), 1229-1237.

Suzuki, K., Tsunekawa, Y., Hernandez-Benitez, R., Wu, J., Zhu, J., Kim, E.J., Hatanaka, F., Yamamoto, M., Araoka, T., Li, Z., Kurita, M., Hishida, T., Li, M., Aizawa, E., Guo, S., Chen, S., Goebl, A., Soligalla, R.D., Qu, J., Jiang, T., Fu, X., Jafari, M., Esteban, C.R., Berggren, W.T., Lajara, J., NuñezDelicado, E., Guillen, P., Campistol, J.M., Matsuzaki, F., Liu, G.-H., Magistretti, P., Zhang, K., Callaway, E.M., Zhang, K., and Belmonte, J.C.I., 2016. In vivo genome editing via CRISPR/Cas9 mediated homologyindependent targeted integration. Nature, 540 (7631), 144-149.

Swarts, D.C., Mosterd, C., van Passel, M.W.J., and Brouns, S.J.J., 2012. CRISPR interference directs strand specific spacer acquisition. PloS One, 7 (4), e35888.

van Swieten, J.C. and Heutink, P., 2008. Mutations in progranulin (GRN) within the spectrum of clinical and pathological phenotypes of frontotemporal dementia. The Lancet. Neurology, 7 (10), 965-974.

Tabebordbar, M., Zhu, K., Cheng, J.K.W., Chew, W.L., Widrick, J.J., Yan, W.X., Maesner, C., Wu, E.Y., Xiao, R., Ran, F.A., Cong, L., Zhang, F., Vandenberghe, L.H., Church, G.M., and Wagers, A.J., 2016. In vivo gene editing in dystrophic mouse muscle and muscle stem cells. Science (New York, N. Y.), 351 (6271), 407-411.

Takahashi, S., Mui, V.J., Rosenberg, S.K., Homma, K., Cheatham, M.A., and Zheng, J., 2016. Cadherin 23-C Regulates Microtubule Networks by Modifying CAMSAP3's Function. Scientific Reports, 6 .

Tamagawa, Y., Kitamura, K., Hagiwara, H., Ishida, T., Nishizawa, M., Saito, T., and Iwamoto, Y., 1997. Audiologic findings in patients with a point mutation at nucleotide 3,243 of mitochondrial DNA. The Annals of Otology, Rhinology, and Laryngology, 106 (4), 338-342.

Tlili, A., Charfedine, I., Lahmar, I., Benzina, Z., Mohamed, B.A., Weil, D., Idriss, N., Drira, M., Masmoudi, S., and Ayadi, H., 2005. Identification of a novel frameshift mutation in the DFNB31/WHRN gene in a Tunisian consanguineous family with hereditary non-syndromic recessive hearing loss. Human Mutation, 25 (5), 503.
Tochitsky, I., Helft, Z., Meseguer, V., Fletcher, R.B., Vessey, K.A., Telias, M., Denlinger, B., Malis, J., Fletcher, E.L., and Kramer, R.H., 2016. How azobenzene photoswitches restore visual responses to the blind retina. Neuron, 92 (1), 100-113.

Tochitsky, I., Kienzler, M.A., Isacoff, E., and Kramer, R.H., 2018. Restoring Vision to the Blind with Chemical Photoswitches. Chemical reviews, 118 (21), 1074810773.

Trevino, A.E. and Zhang, F., 2014. Genome editing using Cas9 nickases. Methods in Enzymology, 546, 161-174.

Tucker, B.A., Mullins, R.F., Streb, L.M., Anfinson, K., Eyestone, M.E., Kaalberg, E., Riker, M.J., Drack, A.V., Braun, T.A., and Stone, E.M., 2013. Patient-specific iPSCderived photoreceptor precursor cells as a means to investigate retinitis pigmentosa. eLife, 2 .

Usami, S. and Nishio, S., 1993. Nonsyndromic Hearing Loss and Deafness, Mitochondrial. In. M.P. Adam, H.H. Ardinger, R.A. Pagon, S.E. Wallace, L.J. Bean, K. Stephens, and A. Amemiya, eds. GeneReviews $B$. Seattle (WA): University of Washington, Seattle.

Usher, C.H., 1935. On a few hereditary eye affections. Transactions of the ophthalmological societies of the United Kingdom, 55, 164-245.

Vaché, C., Besnard, T., le Berre, P., García-García, G., Baux, D., Larrieu, L., Abadie, C., Blanchet, C., Bolz, H.J., Millan, J., Hamel, C., Malcolm, S., Claustres, M., and Roux, A.-F., 2012. Usher syndrome type 2 caused by activation of an USH2A pseudoexon: implications for diagnosis and therapy. Human Mutation, 33 (1), 104-108.

Vaché, C., Besnard, T., Blanchet, C., Baux, D., Larrieu, L., Faugère, V., Mondain, M., Hamel, C., Malcolm, S., Claustres, M., and Roux, A.-F., 2010. Nasal epithelial cells are a reliable source to study splicing variants in Usher syndrome. Human Mutation, 31 (6), 734-741.

Vagni, P., Perlini, L.E., Chenais, N.A.L., Marchetti, T., Parrini, M., Contestabile, A., Cancedda, L., and Ghezzi, D., 2019. Gene editing preserves visual function in a mouse model of retinal degeneration. bioRxiv, 624858 .

Västinsalo, H., Jalkanen, R., Dinculescu, A., Isosomppi, J., Geller, S., Flannery, J.G., Hauswirth, W.W., and Sankila, E.M., 2011. Alternative splice variants of the USH3A gene Clarin 1 (CLRN1). European Journal of Human Genetics, 19 (1), 30-35.

Verbakel, S.K., van Huet, R.A.C., Boon, C.J.F., den Hollander, A.I., Collin, R.W.J., Klaver, C.C.W., Hoyng, C.B., Roepman, R., and Klevering, B.J., 2018. Non-syndromic retinitis pigmentosa. Progress in Retinal and Eye Research, 66, 157-186. 
Verpy, E., Leibovici, M., Zwaenepoel, I., Liu, X.Z., Gal, A., Salem, N., Mansour, A., Blanchard, S., Kobayashi, I., Keats, B.J., Slim, R., and Petit, C., 2000. A defect in harmonin, a PDZ domain-containing protein expressed in the inner ear sensory hair cells, underlies Usher syndrome type 1C. Nature Genetics, 26 (1), 51-55.

Vojta, A., Dobrinić, P., Tadić, V., Bočkor, L., Korać, P., Julg, B., Klasić, M., and Zoldoš, V., 2016. Repurposing the CRISPR-Cas9 system for targeted DNA methylation. Nucleic Acids Research, gkw159.

Wagner, D.L., Amini, L., Wendering, D.J., Burkhardt, L.-M., Akyüz, L., Reinke, P., Volk, H.-D., and SchmueckHenneresse, M., 2019. High prevalence of Streptococcus pyogenes Cas9-reactive $T$ cells within the adult human population. Nature Medicine, 25 (2), 242-248.

Waldron, P.V., Di Marco, F., Kruczek, K., Ribeiro, J., Graca, A.B., Hippert, C., Aghaizu, N.D., Kalargyrou, A.A., Barber, A.C., Grimaldi, G., Duran, Y., Blackford, S.J.I., Kloc, M., Goh, D., Zabala Aldunate, E., Sampson, R.D., Bainbridge, J.W.B., Smith, A.J., Gonzalez-Cordero, A., Sowden, J.C., Ali, R.R., and Pearson, R.A., 2018. Transplanted Donoror Stem Cell-Derived Cone Photoreceptors Can Both Integrate and Undergo Material Transfer in an Environment-Dependent Manner. Stem Cell Reports, 10 (2), 406-421.

Wang, K., Li, M., and Hakonarson, H., 2010. ANNOVAR: functional annotation of genetic variants from highthroughput sequencing data. Nucleic Acids Research, 38 (16), e164-e164.

Wang, L., Jiang, H., and Brigande, J.V., 2012. Gene transfer to the developing mouse inner ear by in vivo electroporation. Journal of Visualized Experiments: JoVE, (64)

Wang, Y., Li, J., Yao, X., Li, W., Du, H., Tang, M., Xiong, W., Chai, R., and Xu, Z., 2017. Loss of CIB2 Causes Profound Hearing Loss and Abolishes Mechanoelectrical Transduction in Mice. Frontiers in Molecular Neuroscience, 10, 401.

Wang, Y., Rajala, A., Cao, B., Ranjo-Bishop, M., Agbaga, M.P., Mao, C., and Rajala, R.V.S., 2016. Cell-Specific Promoters Enable Lipid-Based Nanoparticles to Deliver Genes to Specific Cells of the Retina In Vivo. Theranostics, 6 (10), 1514-1527.

Ward, M.E., Chen, R., Huang, H.-Y., Ludwig, C., Telpoukhovskaia, M., Taubes, A., Boudin, H., Minami, S.S., Reichert, M., Albrecht, P., Gelfand, J.M., CruzHerranz, A., Cordano, C., Alavi, M.V., Leslie, S., Seeley, W.W., Miller, B.L., Bigio, E., Mesulam, M.-M., Bogyo, M.S., Mackenzie, I.R., Staropoli, J.F., Cotman, S.L., Huang, E.J., Gan, L., and Green, A.J., 2017. Individuals with progranulin haploinsufficiency exhibit features of neuronal ceroid lipofuscinosis. Science translational medicine, 9 (385).
Ward, M.E., Taubes, A., Chen, R., Miller, B.L., Sephton, C.F., Gelfand, J.M., Minami, S., Boscardin, J., Martens, L.H., Seeley, W.W., Yu, G., Herz, J., Filiano, A.J., Arrant, A.E., Roberson, E.D., Kraft, T.W., Farese, R.V., Green, A., and Gan, L., 2014. Early retinal neurodegeneration and impaired Ran-mediated nuclear import of TDP-43 in progranulin-deficient FTLD. The Journal of Experimental Medicine, 211 (10), 1937-1945.

Wauters, E., Van Mossevelde, S., Van der Zee, J., Cruts, M., and Van Broeckhoven, C., 2017. Modifiers of GRNAssociated Frontotemporal Lobar Degeneration. Trends in Molecular Medicine, 23 (10), 962-979.

Wei, C., Yang, L., Cheng, J., Imani, S., Fu, S., Lv, H., Li, Y., Chen, R., Leung, E.L.-H., and Fu, J., 2018. A novel homozygous variant of GPR98 causes usher syndrome type IIC in a consanguineous Chinese family by next generation sequencing. BMC Medical Genetics, 19.

Wei, L., Levine, A.S., and Lan, L., 2016. Transcriptioncoupled homologous recombination after oxidative damage. DNA repair, 44, 76-80.

Wei, X., Sun, Y., Xie, J., Shi, Q., Qu, N., Yang, G., Cai, J., Yang, Y., Liang, Y., Wang, W., and Yi, X., 2012. Next-generation sequencing identifies a novel compound heterozygous mutation in MYO7A in a Chinese patient with Usher Syndrome 1B. Clinica Chimica Acta; International Journal of Clinical Chemistry, 413 (23-24), 1866-1871.

Weil, D., Blanchard, S., Kaplan, J., Guilford, P., Gibson, F., Walsh, J., Mburu, P., Varela, A., Levilliers, J., and Weston, M.D., 1995. Defective myosin VIIA gene responsible for Usher syndrome type 1B. Nature, 374 (6517), 60-61.

Weil, D., El-Amraoui, A., Masmoudi, S., Mustapha, M., Kikkawa, Y., Lainé, S., Delmaghani, S., Adato, A., Nadifi, S., Zina, Z.B., Hamel, C., Gal, A., Ayadi, H., Yonekawa, H., and Petit, C., 2003. Usher syndrome type I G (USH1G) is caused by mutations in the gene encoding SANS, a protein that associates with the USH1C protein, harmonin. Human Molecular Genetics, 12 (5), 463-471.

Weil, D., Küssel, P., Blanchard, S., Lévy, G., Levi-Acobas, F., Drira, M., Ayadi, H., and Petit, C., 1997. The autosomal recessive isolated deafness, DFNB2, and the Usher 1B syndrome are allelic defects of the myosin-VIIA gene. Nature Genetics, 16 (2), 191-193.

Welch, E.M., Barton, E.R., Zhuo, J., Tomizawa, Y., Friesen, W.J., Trifillis, P., Paushkin, S., Patel, M., Trotta, C.R., Hwang, S., Wilde, R.G., Karp, G., Takasugi, J., Chen, G., Jones, S., Ren, H., Moon, Y.-C., Corson, D., Turpoff, A.A., Campbell, J.A., Conn, M.M., Khan, A., Almstead, N.G., Hedrick, J., Mollin, A., Risher, N., Weetall, M., Yeh, S., Branstrom, A.A., Colacino, J.M., Babiak, J., Ju, W.D., Hirawat, S., Northcutt, V.J., Miller, L.L., Spatrick, P., He, F., Kawana, M., Feng, H., Jacobson, A., Peltz, S.W., and Sweeney, H.L., 2007. PTC124 targets genetic disorders caused by nonsense mutations. Nature, 447 (7140), 8791. 
Weston, M.D., Eudy, J.D., Fujita, S., Yao, S., Usami, S., Cremers, C., Greenberg, J., Ramesar, R., Martini, A., Moller, C., Smith, R.J., Sumegi, J., Kimberling, W.J., and Greenburg, J., 2000. Genomic structure and identification of novel mutations in usherin, the gene responsible for Usher syndrome type Ila. American Journal of Human Genetics, 66 (4), 1199-1210.

Weston, M.D., Luijendijk, M.W.J., Humphrey, K.D., Möller, C., and Kimberling, W.J., 2004. Mutations in the VLGR1 gene implicate G-protein signaling in the pathogenesis of Usher syndrome type II. American Journal of Human Genetics, 74 (2), 357-366.

White, J.K., Gerdin, A.-K., Karp, N.A., Ryder, E., Buljan, M., Bussell, J.N., Salisbury, J., Clare, S., Ingham, N.J., Podrini, C., Houghton, R., Estabel, J., Bottomley, J.R., Melvin, D.G., Sunter, D., Adams, N.C., Baker, L., Barnes, C., Beveridge, R., Cambridge, E., Carragher, D., Chana, P., Clarke, K., Hooks, Y., Igosheva, N., Ismail, O., Jackson, H., Kane, L., Lacey, R., Lafont, D.T., Lucas, M., Maguire, S., McGill, K., McIntyre, R.E., Messager, S., Mottram, L., Mulderrig, L., Pearson, S., Protheroe, H.J., Roberson, L.-A., Salsbury, G., Sanderson, M., Sanger, D., Shannon, C., Thompson, P.C., Tuck, E., Vancollie, V.E., Brackenbury, L., Bushell, W., Cook, R., Dalvi, P., Gleeson, D., Habib, B., Hardy, M., Liakath-Ali, K., Miklejewska, E., Price, S., Sethi, D., Trenchard, E., von Schiller, D., Vyas, S., West, A.P., Woodward, J., Wynn, E., Evans, A., Gannon, D., Griffiths, M., Holroyd, S., Iyer, V., Kipp, C., Lewis, M., Li, W., Oakley, D., Richardson, D., Smedley, D., Agu, C., Bryant, J., Delaney, L., Gueorguieva, N.I., Tharagonnet, H., Townsend, A.J., Biggs, D., Brown, E., Collinson, A., Dumeau, C.-E., Grau, E., Harrison, S., Harrison, J., Ingle, C.E., Kundi, H., Madich, A., Mayhew, D., Metcalf, T., Newman, S., Pass, J., Pearson, L., Reynolds, H., Sinclair, C., Wardle-Jones, H., Woods, M., Alexander, L., Brown, T., Flack, F., Frost, C., Griggs, N., Hrnciarova, S., Kirton, A., McDermott, J., Rogerson, C., White, G., Zielezinski, P., DiTommaso, T., Edwards, A., Heath, E., Mahajan, M.A., Yalcin, B., Tannahill, D., Logan, D.W., MacArthur, D.G., Flint, J., Mahajan, V.B., Tsang, S.H., Smyth, I., Watt, F.M., Skarnes, W.C., Dougan, G., Adams, D.J., Ramirez-Solis, R., Bradley, A., and Steel, K.P., 2013. Genome-wide Generation and Systematic Phenotyping of Knockout Mice Reveals New Roles for Many Genes. Cell, 154 (2), 452-464.

van Wijk, E., Pennings, R.J.E., te Brinke, H., Claassen, A., Yntema, H.G., Hoefsloot, L.H., Cremers, F.P.M., Cremers, C.W.R.J., and Kremer, H., 2004. Identification of 51 novel exons of the Usher syndrome type 2A (USH2A) gene that encode multiple conserved functional domains and that are mutated in patients with Usher syndrome type II. American Journal of Human Genetics, 74 (4), 738-744. van Wijk, E., van der Zwaag, B., Peters, T., Zimmermann, U., Te Brinke, H., Kersten, F.F.J., Märker, T., Aller, E., Hoefsloot, L.H., Cremers, C.W.R.J., Cremers, F.P.M., Wolfrum, U., Knipper, M., Roepman, R., and Kremer, $\mathrm{H}_{\text {., }}$ 2006. The DFNB31 gene product whirlin connects to the Usher protein network in the cochlea and retina by direct association with USH2A and VLGR1. Human Molecular Genetics, 15 (5), 751-765.

Wilde, J.J., Aida, T., Wienisch, M., Zhang, Q., Qi, P., and Feng, G., 2018. Efficient Zygotic Genome Editing via RAD51-Enhanced Interhomolog Repair. bioRxiv, 263699.

Williams, D.S., Chadha, A., Hazim, R., and Gibbs, D., 2017. Gene therapy approaches for prevention of retinal degeneration in Usher syndrome. Gene Therapy, 24 (2), 68-71.

Wolfrum, U. and Schmitt, A., 2000. Rhodopsin transport in the membrane of the connecting cilium of mammalian photoreceptor cells. Cell Motility and the Cytoskeleton, 46 (2), 95-107.

Wright, C.F., McRae, J.F., Clayton, S., Gallone, G., Aitken, S., FitzGerald, T.W., Jones, P., Prigmore, E., Rajan, D., Lord, J., Sifrim, A., Kelsell, R., Parker, M.J., Barrett, J.C., Hurles, M.E., FitzPatrick, D.R., and Firth, H.V., 2018. Making new genetic diagnoses with old data: iterative reanalysis and reporting from genome-wide data in 1,133 families with developmental disorders. Genetics in Medicine, 20 (10), 1216.

Wu, L., Pan, L., Wei, Z., and Zhang, M., 2011. Structure of MyTH4-FERM domains in myosin VIla tail bound to cargo. Science (New York, N.Y.), 331 (6018), 757-760.

Wu, W.-L., Wang, C.-H., Huang, E.Y.-K., and Chen, C.-C., 2009. Asic3(-/-) female mice with hearing deficit affects social development of pups. PloS One, 4 (8), e6508.

Xia, H., Hu, P., Yuan, L., Xiong, W., Xu, H., Yi, J., Yang, Z., Deng, X., Guo, Y., and Deng, H., 2017. A homozygous MYO7A mutation associated to Usher syndrome and unilateral auditory neuropathy spectrum disorder. Molecular Medicine Reports, 16 (4), 4241-4246.

Xie, N., Zhou, Y., Sun, Q., and Tang, B., 2018. Novel Epigenetic Techniques Provided by the CRISPR/Cas9 System. Stem Cells International, 2018.

Yagi, H., Tokano, H., Maeda, M., Takabayashi, T., Nagano, T., Kiyama, H., Fujieda, S., Kitamura, K., and Sato, M., 2007. Vlgr1 is required for proper stereocilia maturation of cochlear hair cells. Genes to Cells: Devoted to Molecular \& Cellular Mechanisms, 12 (2), 235-250.

Yang, J., Huang, X.-F., Tong, Y., and Jin, Z.-B., 2016. Targeted exome sequencing identified two novel truncation mutations in GPR98 causing Usher syndrome. Clinical \& Experimental Ophthalmology, 44 (3), 197-199. 
Yang, J., Liu, X., Zhao, Y., Adamian, M., Pawlyk, B., Sun, X., McMillan, D.R., Liberman, M.C., and Li, T., 2010. Ablation of whirlin long isoform disrupts the USH2 protein complex and causes vision and hearing loss. PLOS genetics, 6 (5), e1000955.

Yang, J., Wang, L., Song, H., and Sokolov, M., 2012. Current Understanding of Usher Syndrome Type II. Frontiers in bioscience : a journal and virtual library, 17, 1165-1183.

Yang, M., Peng, S., Sun, R., Lin, J., Wang, N., and Chen, C., 2018. The Conformational Dynamics of Cas9 Governing DNA Cleavage Are Revealed by Single-Molecule FRET. Cell Reports, 22 (2), 372-382.

Yang, T., Wei, X., Chai, Y., Li, L., and Wu, H., 2013. Genetic etiology study of the non-syndromic deafness in Chinese Hans by targeted next-generation sequencing. Orphanet Journal of Rare Diseases, 8, 85.

Yeo, G. and Burge, C.B., 2004. Maximum entropy modeling of short sequence motifs with applications to RNA splicing signals. Journal of Computational Biology: A Journal of Computational Molecular Cell Biology, 11 (23), 377-394.

Yoshimura, H., Iwasaki, S., Nishio, S.-Y., Kumakawa, K., Tono, T., Kobayashi, Y., Sato, H., Nagai, K., Ishikawa, K., Ikezono, T., Naito, Y., Fukushima, K., Oshikawa, C., Kimitsuki, T., Nakanishi, H., and Usami, S.-I., 2014. Massively parallel DNA sequencing facilitates diagnosis of patients with Usher syndrome type 1. PloS One, 9 (3), e90688.

Yu, C., Liu, Y., Ma, T., Liu, K., Xu, S., Zhang, Y., Liu, H., La Russa, M., Xie, M., Ding, S., and Qi, L.S., 2015. Small molecules enhance CRISPR genome editing in pluripotent stem cells. Cell Stem Cell, 16 (2), 142-147.

Yu, C.-E., Bird, T.D., Bekris, L.M., Montine, T.J., Leverenz, J.B., Steinbart, E., Galloway, N.M., Feldman, H., Woltjer, R., Miller, C.A., Wood, E.M., Grossman, M., McCluskey, L., Clark, C.M., Neumann, M., Danek, A., Galasko, D.R., Arnold, S.E., Chen-Plotkin, A., Karydas, A., Miller, B.L., Trojanowski, J.Q., Lee, V.M.-Y., Schellenberg, G.D., and Deerlin, V.M.V., 2010. The Spectrum of Mutations in Progranulin: A Collaborative Study Screening 545 Cases of Neurodegeneration. Archives of neurology, 67 (2), 161.

Zallocchi, M., Binley, K., Lad, Y., Ellis, S., Widdowson, P., lqball, S., Scripps, V., Kelleher, M., Loader, J., Miskin, J., Peng, Y.-W., Wang, W.-M., Cheung, L., Delimont, D., Mitrophanous, K.A., and Cosgrove, D., 2014. EIAV-Based Retinal Gene Therapy in the shaker1 Mouse Model for Usher Syndrome Type 1B: Development of UshStat. PLOSONE, 9 (4).
Zallocchi, M., Meehan, D.T., Delimont, D., Askew, C., Garige, S., Gratton, M.A., Rothermund-Franklin, C.A., and Cosgrove, D., 2009. Localization and expression of clarin-1, the Clrn1 gene product, in auditory hair cells and photoreceptors. Hearing Research, 255 (1-2), 109120.

Zhai, W., Jin, X., Gong, Y., Qu, L.-H., Zhao, C., and Li, Z.-H., 2015. Phenotype of Usher syndrome type II assosiated with compound missense mutations of $\mathrm{c} .721 \mathrm{C}>\mathrm{T}$ and c.1969 C>T in MYO7A in a Chinese Usher syndrome family. International Journal of Ophthalmology, 8 (4), 670-674.

Zhang, K., Xu, Z.P., Lu, J., Tang, Z.Y., Zhao, H.J., Good, D.A., and Wei, M.Q., 2014. Potential for layered double hydroxides-based, innovative drug delivery systems. International Journal of Molecular Sciences, 15 (5), 7409-7428.

Zhang, N., Wang, J., Liu, S., Liu, M., and Jiang, F., 2018. Identification of two novel compound heterozygous mutations of ADGRV1 in a Chinese family with Usher syndrome type IIC. Ophthalmic Genetics, 39 (4), 517521.

Zhao, L., Chen, G., Li, J., Fu, Y., Mavlyutov, T.A., Yao, A., Nickells, R.W., Gong, S., and Guo, L.-W., 2017. An intraocular drug delivery system using targeted nanocarriers attenuates retinal ganglion cell degeneration. Journal of Controlled Release: Official Journal of the Controlled Release Society, 247, 153-166.

Zheng, L., Zheng, J., Whitlon, D.S., García-Añoveros, J., and Bartles, J.R., 2010. Targeting of the hair cell proteins cadherin 23 , harmonin, myosin XVa, espin, and prestin in an epithelial cell model. The Journal of Neuroscience: The Official Journal of the Society for Neuroscience, 30 (21), 7187-7201.

Zheng, S.-L., Zhang, H.-L., Lin, Z.-L., and Kang, Q.-Y., 2015. Whole-exome sequencing identifies USH2A mutations in a pseudo-dominant Usher syndrome family. International Journal of Molecular Medicine, 36 (4), 1035-1041.

Zhu, H., Misel, L., Graham, M., Robinson, M.L., and Liang, C., 2016. CT-Finder: A Web Service for CRISPR Optimal Target Prediction and Visualization. Scientific Reports, 6.

Zou, J., Luo, L., Shen, Z., Chiodo, V.A., Ambati, B.K., Hauswirth, W.W., and Yang, J., 2011. Whirlin Replacement Restores the Formation of the USH2 Protein Complex in Whirlin Knockout Photoreceptors. Investigative Ophthalmology \& Visual Science, 52 (5), 2343-2351.

Zrada, S.E., Braat, K., Doty, R.L., and Laties, A.M., 1996. Olfactory loss in Usher syndrome: another sensory deficit? American Journal of Medical Genetics, 64 (4), 602-603. 
